WSRC-RP-96-00111, Revision 0

March 1996

\title{
RFI/RI WORK PLAN FOR 716-A MOTOR SHOPS SEEPAGE BASIN (U)
}

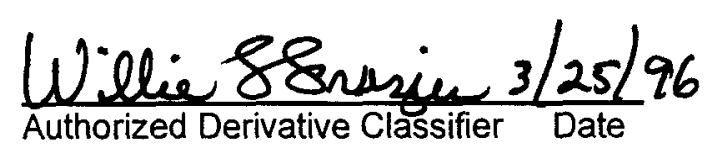

Westinghouse Savannah River Company Savannah River Site Aiken, SC 29808

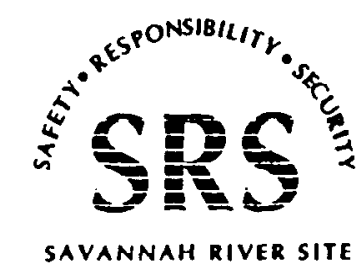

Prepared for the US Department of Energy Contract Number DE- $\Lambda$ CO9-89SR18035 
This document was prepared in conjunction with work accomplished under Contract No. DE-AC09-96SR18500 with the U.S. Department of Energy.

\section{DISCLAIMER}

This report was prepared as an account of work sponsored by an agency of the United States Government. Neither the United States Government nor any agency thereof, nor any of their employees, makes any warranty, express or implied, or assumes any legal liability or responsibility for the accuracy, completeness, or usefulness of any information, apparatus, product or process disclosed, or represents that its use would not infringe privately owned rights. Reference herein to any specific commercial product, process or service by trade name, trademark, manufacturer, or otherwise does not necessarily constitute or imply its endorsement, recommendation, or favoring by the United States Government or any agency thereof. The views and opinions of authors expressed herein do not necessarily state or reflect those of the United States Government or any agency thereof.

This report has been reproduced directly from the best available copy.

Available for sale to the public, in paper, from: U.S. Department of Commerce, National Technical Information Service, 5285 Port Royal Road, Springfield, VA 22161, phone: (800) 553-6847, fax: (703) 605-6900

email: orders@ntis.fedworld.gov

online ordering: http://www.ntis.gov/support/index.html

Available electronically at http://www.doe.gov/bridge

Available for a processing fee to U.S. Department of Energy and its contractors, in paper, from: U.S. Department of Energy, Office of Scientific and Technical Information, P.O. Box 62, Oak Ridge, TN 37831-0062, \&nbsp;phone: (865 ) 576-8401, \&nbsp;fax: (865) 576-5728,

email: reportseadonis.osti.gov 


\title{
CERTIFICATION PAGE
}

\section{Revision 0 RCRA Facility Investigation/Remedial Investigation Work Plan for the 716-A Motor Shops Seepage Basin}

\author{
Savannah River Site \\ Aiken, South Carolina
}

\begin{abstract}
"I certify under penalty of law that this document and all attachments were prepared under my direction or supervision in accordance with a system designed to ensure that qualified personnel properly gather and evaluate the information submitted. Based on my inquiry of the person or persons who manage the system, or those persons directly responsible for gathering the information, the information submitted is, to the best of my knowledge and belief, true, accurate, and complete. I am aware that there are significant penalties for submitting false information including the possibility of fine and imprisonment for knowing violations."
\end{abstract}

Date: $\quad 3 / 25 / 96$

Date: $\quad 3 / 29 / 96$
Signature: Title:

Signature: Title:
A. M. Schwartzman, Program Manager

Environmental Restoration Department

Westinghouse Savannah River Company Contractor for the U.S. Department of Energy, Savannah River Operations

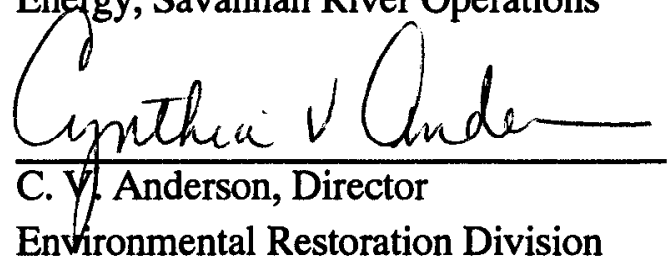

U.S. Department of Energy

Savannah River Field Office 


\author{
REVISION 0 \\ RCRA FACILITY INVESTIGATION/ \\ REMEDIAL INVESTIGATION WORK PLAN \\ FOR THE 716-A MOTOR SHOPS SEEPAGE BASIN
}

DISCLAIMER

This report was prepared for the United States Department of Energy under Contract No. DE-AC09-89SR18035 and is an account of work performed under that contract. Reference herein to any specific commercial product, process, or service by trademark, name, manufacturer or otherwise does not necessarily constitute or imply endorsement, recommendation, or favoring of same by Westinghouse Savannah River Company or by the United States Government or any agency thereof. 


\section{TABLE OF CONTENTS}

EXECUTIVE SUMMARY E-1

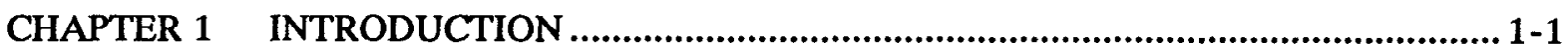

1.1 General.................................................................................... 1-1

1.2 Regulatory Background................................................................ 1 1-2

1.2.1 RCRA Facility Investigation Program ................................... 1-2

1.3 1.2.2 CERCLA Remedial Investigation Program................................. 1-2

1.3.1 716-A Motor Shops Seepage Basin ......................................... 1-4

1.4 General RFI/RI Investigation Procedures........................................... 1-4

CHAPTER 2 PRELIMINARY UNIT EVALUATION RESULTS .......................................2 2-1

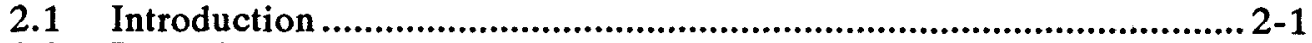

2.2 Preliminary Unit Evaluation Procedures................................................. 2-1

2.2.1 Existing Literature and Information .....................................2-1

2.2.2 RCRA/CERCLA Unit Reconnaissance ...................................... 2-2

2.3 Preliminary Unit Evaluation Results............................................... 2-2

2.3.1 RCRA/CERCLA Unit Disposal History and Waste

Characteristics .................................................................... 2-2

2.3.2 Ecological Setting ............................................................... 2-3

2.3.3 Environmental Setting.................................................. 2-3

2.3.3.1 Physiographic Setting........................................2-3

2.4 Geology and Hydrogeology of the SRS........................................... 2-4

2.4.1 Geology/Stratigraphic Sequence............................................ 2-4

2.4.1.1 Paleozoic and Triassic .......................................... 2-4

2.4.1.2 Cretaceous.............................................................. 2-4

2.4.1.3 Paleocene and Early Eocene..................................... 2-4

2.4.1.4 Eocene................................................................... 2-5

2.4.2 Hydrogeology of the SRS ............................................... 2-6

2.5 Hydrogeologic Setting of the A-Area ................................................ 2-7

2.5.1 Physiography and Drainage ............................................... 2-7

2.5.2 Surface and Subsurface Soils................................................... 2-7

2.6 Preliminary Unit Evaluation Results

CHAPTER 3 CONCEPTUAL SITE MODEL AND SURVEY OF HISTORICAL

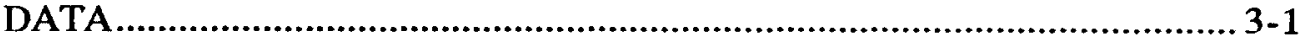

3.1 Introduction and Objective ........................................................... 3-1

3.2 Conceptual Site Model.................................................................. 3-1

3.2.1 716-A Motor Shops Seepage Basin Conceptual Site

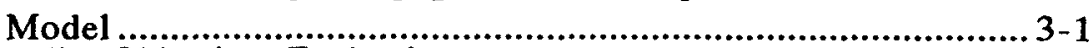

3.3 Data Quality Objectives Evaluation .................................................... 3-3 


\section{TABLE OF CONTENTS \\ (CONTINUED)}

Page

3.4 Remediation Objectives and Assessment Endpoints............................... 3-7

3.4.1 Human Health Remediation Objectives..................................... 3-7

3.4.2 Ecological Assessment Endpoints....................................................3-8

3.5 Survey of Historical Data ...................................................................... 3-10

3.5.1 A-Area and M-Area Regional Groundwater Quality ................. 3-10

3.5.2 Monitoring Well Data............................................................... 3-12

3.5.3 Unit Screening …...................................................................... 3-12

3.5.4 Soil Gas Investigation................................................................. 3-13

3.5.5 Adequacy of Historical Data and New Data Needs.................... 3-14

CHAPTER 4 UNIT ASSESSMENT............................................................................ 4-1

4.1 Characterization Plan Summary .......................................................... 4-1

4.2 Unit Decision Rules and Respective Data Needs ...................................... 4-2

4.3 Unit Assessment Objectives.......................................................................... 4-6

4.4 Unit Assessment Analytes ...........................................................................4-6

4.5 Sampling Plan .................................................................................. 4-7

4.5.1 Background Characterization ......................................................... 4-7

4.5.2 Motor Shops Seepage Basin Sampling Plan................................. 4-8

4.5.3 Investigative Derived Waste Identification, Generation, and Management..................................................................... 4-11

CHAPTER 5 SCHEDULE FOR RFI/RI ACTIVITIES AND DOCUMENT

SUBMITTALS.............................................................................................. 5-1

5.1 Introduction .........................................................................................5-1

5.2 Projected Schedule for Field Activities..................................................... 5-1

5.3 Projected Schedule for Document and Report Submittals......................... 5-1

CHAPTER 6 SAFETY, HEALTH AND EMERGENCY RESPONSE PLAN ............................ 6-1

CHAPTER 7 QUALITY ASSURANCE/QUALITY CONTROL ............................................. 7-1

CHAPTER 8 DATA MANAGEMENT PLAN ................................................................... 8-1

CHAPTER 9 REFERENCES ..................................................................................... 9-1 


\section{TABLE OF CONTENTS (CONTINUED)}

$\begin{array}{ll}\text { APPENDIX A.1 } & \text { RCRA/CERCLA UNIT LITERATURE REVIEW CHECKLIST } \\ \text { APPENDIX A.2 } & \text { UNIT RECONNAISSANCE FIELD DATA SHEET } \\ \text { APPENDIX A.3 } & \text { DATA QUALITY OBJECTIVES WORKSHEET } \\ \text { APPENDIX A.4 } & \text { SITE PHOTOS } \\ \text { APPENDIX B } & \text { GROUNDWATER DATA }\end{array}$




\section{TABLE OF CONTENTS (CONTINUED)}

\section{LIST OF FIGURES}

No.

1-1 Location of Savannah River Site in South-Central South Carolina

1-2 Location of Major Facilities at Savannah River Site

1-3 Motor Shops Seepage Basin Location Map

2-1 Physiographic Subprovinces of the South Carolina Coastal Plain

2-2 Major Tributaries to the Savannah River at Savannah River Site

2-3 Comparison of Chronostratigraphic, Lithostratigraphic, and Hydrostratigraphic Units at the Savannah River Site

2-4 Hydrogeologic Nomenclature for the Savannah River Site

2-5 Hydrostratigraphic Chart for the A/M-Area

2-6 Potentiometric Surface of the "M-Area" Aquifer Zone, Met Lab Vicinity

2-7 Potentiometric Surface of the Upper "Lost Lake" Aquifer Zone, Met Lab Vicinity

2-8 Potentiometric Surface of the Lower "Lost Lake" Aquifer Zone, Met Lab Vicinity

2-9 Potentiometric Surface of the "Middle Sand" Aquifer Zone, Met Lab Vicinity

2-10 Potentiometric Surface of the Crouch Branch Aquifer, Met Lab Vicinity

3-1 Schematic Diagram Across A-Area

3-2 Conceptual Site Model for the 716-A Motor Shops Seepage Basin

3-3 Exposure Pathways for Potential Receptors: 716-A Motor Shops Seepage Basin

3-4 TCE Isoconcentration Map for "M-Area" Aquifer Zone (Water Table)

3-5 PCE Isoconcentration Map for "M-Area" Aquifer Zone (Water Table)

3-6 Motor Shops Seepage Basin Monitoring Well Locations

3-7 Motor Shops Seepage Basin Soil Boring Locations from Previous Study

4-1 Decision Logic for Soil Investigation

4-2 Decision Logic for Process Sewer Line Investigation

4-3 Decision Logic for Groundwater Investigation

4-4 Motor Shops Seepage Basin Background Characterization Locations

4-5 Motor Shops Seepage Basin Sample Locations

4-6 Sampling Logic for Determining Vertical Extent of Contamination

5-1 Proposed Schedule of Field Activities and Document and Report Submittals for 716-A Motor Shops Seepage Basin 


\section{TABLE OF CONTENTS (CONTINUED)}

\section{LIST OF TABLES}

No.

Title

3.1 Summary of Data Quality Objectives for 716-A Motor Shops Seepage Basin 3-16

3.2 List of Constituents Detected Above the Primary Drinking Water Standards in Groundwater During at Least One Quarter Between the First Quarter of 1991 to the Fourth Quarter of 1995 Motor Shops Seepage Basin

3.3 Sampling Intervals and Constituents Analyzed 716-A Motor Shops Seepage Basin ......3-18

3.4 Chemical Analysis Results for Soils 716-A Motor Shops Seepage Basin

3.5 Soil Gas Survey Results for Motor Shops Seepage Basin (716-A).

4.1 Unit Data Needs and Proposed Characterization Activities 716-A Motor Shops

Seepage Basin

4.2 Analytical Parameters for 716-A Motor Shops Seepage Basin

4.3 Summary of Samples and Constituents to be Analyzed for Background Characterization.

4.4 Summary of Samples and Constituents to be Analyzed 716-A Motor Shops Seepage Basin

4.5 Summary of Number of Field Samples and QA/QC Samples 


\section{LIST OF ACRONYMS}

$\begin{array}{lll}\text { BRA } & - \text { Baseline Risk Assessment } \\ \text { BTEX } & - \text { Benzene, Toluene, Ethylbenzene, and Xylenes } \\ \text { CAB } & - \text { Citizens Advisory Board } \\ \text { CERCLA } & - \text { Comprehensive Environmental Response, Compensation, and } \\ & & \text { Liability Act } \\ \text { COPCs } & - & \text { Chemicals of Potential Concern } \\ \text { CPT } & - & \text { Cone Penetrometer Technology } \\ \text { CSM } & - \text { Conceptual Site Model } \\ \text { DCF } & - \text { Dose Conversion Factor } \\ \text { DNAPL } & - \text { Dense Nonaqueous Phase Liquid } \\ \text { DOE } & - \text { Department of Energy } \\ \text { DP } & - \text { Direct Push } \\ \text { DQO } & - \text { Data Quality Objectives } \\ \text { EHRAV } & - \text { Electronic Handbook of Risk Assessment Values } \\ \text { EID } & - \text { Environmental Information Document } \\ \text { EIS } & - \text { Environmental Impact Statement } \\ \text { EPA } & - \text { U.S. Environmental Protection Agency } \\ \text { ESC } & - \text { Expedited Site Characterization } \\ \text { FS } & - \text { Feasibility Study } \\ \text { GPR } & - \text { Ground Penetrating Radar } \\ \text { GSA } & - \text { General Separations Area } \\ \text { HEAST } & - \text { Health Effects Assessment Summary Tables } \\ \text { HI } & - \text { Hazard Index } \\ \text { HQ } & - \text { Hazard Quotients } \\ \text { HSWA } & - \text { Hazardous and Solid Waste Amendments } \\ & \end{array}$




\section{LIST OF ACRONYMS (Continued)}

$\begin{array}{ll}\text { HWMF } & \text { - } \text { Hazardous Waste Management Facility } \\ \text { IDW } & \text { - } \text { Investigative Derived Waste } \\ \text { IOUs } & \text { - Integrator Operable Units } \\ \text { IRIS } & \text { - Integrated Risk Information System } \\ \text { MCLs } & - \text { Maximum Contaminant Levels } \\ \text { MEK } & - \text { Methy Ethyl Ketone } \\ \text { MSSB } & - \text { Motor Shops Seepage Basin } \\ \text { NEPA } & - \text { National Environmental Policy Act } \\ \text { NPDES } & - \text { National Pollutant Discharge Elimination System } \\ \text { NPL } & - \text { National Priorities List } \\ \text { OUs } & - \text { Operable Units } \\ \text { OVA } & - \text { Organic Vapor Analyzer } \\ \text { PAHs } & - \text { Polycyclic Aromatic Hydrocarbons } \\ \text { PCE } & - \text { Tetrachloroethylene } \\ \text { PDWS } & - \text { Primary Drinking Water Standards } \\ \text { PPE } & - \text { Personal Protective Equipment } \\ \text { PRG } & - \text { Preliminary Remediation Goal } \\ \text { PVC } & - \text { Polyvinyl Chloride } \\ \text { QA/QC } & - \text { Quality Assurance/Quality Control } \\ \text { RBC } & - \text { Risk-Based Concentration } \\ \text { RCRA } & - \text { Resource Conservation and Recovery Act } \\ \text { RDA } & - \text { Recommended Daily Allowance } \\ \text { RFD } & - \text { Reference Dose } \\ \text { RFI } & - \text { RCRA Facility Investigation } \\ \text { RI } & - \text { Remedial Investigation } \\ \text { RME } & - \text { Reasonable Maximum Exposure } \\ & \end{array}$




\section{LIST OF ACRONYMS}

(Continued)

$\begin{array}{ll}\text { SADI } & - \text { Safe and Adequate Daily Intake } \\ \text { SCDHEC } & - \text { South Carolina Department of Health and Environmental Control } \\ \text { SF } & - \text { Slope Factor } \\ \text { SRS } & - \text { Savannah River Site } \\ \text { SRTC } & - \text { Savannah River Technology Center } \\ \text { SVOCs } & - \text { Semivolatile Organic Compounds } \\ \text { SWMU } & - \text { Solid Waste Management Unit } \\ \text { TAL } & - \text { Target Analyte List } \\ \text { TBD } & - \text { To Be Determined } \\ \text { TCA } & - \text { 1,1,1-Trichloroethane } \\ \text { TCE } & - \text { Trichloroethylene } \\ \text { TCL W/TIC } & - \text { Target Compound List with Tentatively Identified Compounds } \\ \text { TOC } & - \text { Total Organic Carbon } \\ \text { UCL95 } & - \text { 95\% Upper Confidence Limit } \\ \text { USC } & - \text { Unit-Specific Contaminant } \\ \text { VOCs } & - \text { Volatile Organic Compounds } \\ \text { WSRC } & - \text { Westinghouse Savannah River Company }\end{array}$




\section{EXECUTIVE SUMMARY}

This work plan is prepared for the 716-A Motor Shops Seepage Basin, which is located in the A-Area at the Savannah River Site in Aiken, South Carolina. This work plan will present an investigation designed to follow Comprehensive Environmental Response, Compensation, and Liability Act/Resource Conservation and Recovery Act (CERCLA/RCRA) procedures in conducting a RCRA Facility Investigation/Remedial Investigation (RFI/RI) and to support the following objectives:

1. Evaluation of the nature and extent of contamination related to the 716-A Motor Shops Seepage Basin;

2. Preparation of a baseline risk assessment (BRA);

3. Evaluation of whether potential contamination in the groundwater is stratified and, if so, whether different levels of contamination can be attributed to the 716-A Motor Shops Seepage Basin; and

4. Preparation of a treatability study/feasibility study report.

The 716-A Motor Shops Seepage Basin was constructed and placed in service in 1977 to receive liquid waste from the 716-A Motor Shops oil/water separator. Wastewater flowed into the basin from the northwest through influent pipes from the Motor Shop (Building 716-A). The liquid wastes seeped naturally into the soil beneath the basin. The basin has not been closed, but all discharges to the basin were terminated in 1983 and the influent lines from the Motor Shops were capped (Huber et. al., 1987). Effluent discharges from the Motor Shops included wastewater with trace amounts of engine oil, grease, kerosenes, ethylene glycol, and soapy water.

Standard procedures for RCRA/CERCLA unit investigations include a review of specific investigatory phases within the RFI/RI process. For the Motor Shops Seepage Basin, the preliminary unit evaluation and the unit screening phase have been completed. Waste disposal records and sampling/monitoring data indicate that the 716-A Motor Shops Seepage Basin has received hazardous waste. Therefore, according to the RFI/RI Program Plan, a Unit Screening program was required to identify any areas of hazardous substance release to the soil or groundwater.

Based on the unit screening data, hazardous materials have been managed at the Motor Shops Seepage Basin and additional investigations are required, in accordance with the RFI/RI Program Plan. Sufficient historical data are not available to determine the nature 
and extent of contamination in the Motor Shops Seepage Basin. Additional data are needed to determine the vertical and horizontal extent of contamination and for input to conduct the BRA.

This document presents the work plan for assessment of the nature and extent, if any, of contaminant migration from the site. Data collected will be used to prepare a baseline risk assessment that analyzes the risks posed by the unit to both human health and the environment. These data will also assist in identifying and evaluating remediation alternatives.

The data gaps identified by the Data Quality Objectives process for the Motor Shops Seepage Basin are listed below:

- Data to establish background concentrations for chemicals of potential concern in surface soils, subsurface soils and groundwater;

- Data for determining the contaminants in the surface soil, subsurface soil and groundwater;

- Data for determining the local stratigraphy and groundwater levels and flow rate and direction; and

- Geotechnical data for determining remedial alternatives.

The goal of the Unit Assessment for the Motor Shops Seepage Basin is to determine if hazardous or radioactive substances are present in the Basin and, if so, whether releases have occurred to surrounding soils or groundwater. If it is determined that surrounding media have been impacted, sampling will be performed until the extent of contamination has been evaluated.

The field investigation has been designed to achieve the following objectives:

- Evaluate the unit-specific background or reference levels for organics and inorganics in all media of concern;

- Define the subsurface lithology down to the first confining unit (top of Crouch Branch confining unit);

- Determine the depth to groundwater and groundwater flow direction in the water table aquifer;

- Determine the nature and extent of contamination related to the Motor Shops Seepage Basin;

- Determine if potential contamination in the groundwater is stratified and, if so, whether different levels of contamination can be attributed to different sources;

- Collect data needed to support the human health and ecological baseline risk assessment; and 
- Collect data to support treatability/feasibility study.

The assessment of the environmental media will be accomplished using the principles of the Expedited Site Characterization (ESC) methodology. ESC incorporates on-site decision-making technologies that permit site characterizations to be completed in a streamlined manner.

The field work will be divided into two phases. During Phase 1, surface and subsurface soils from within the basin will be sampled and analyzed to determine if any unit specific contaminants (USCs) are present. If so, Phase 2 will be performed to determine the nature and extent of contamination in surface soils, subsurface soils, deep subsurface soils and groundwater. 


\section{CHAPTER 1 INTRODUCTION}

\subsection{GENERAL}

This work plan is prepared for the 716-A Motor Shops Seepage Basin (MSSB) which is located in the A-Area at the Savannah River Site. This work plan will present an investigation designed to follow Comprehensive Environmental Response, Compensation, and Liability Act/Resource Conservation and Recovery Act (CERCLA/RCRA) procedures in conducting a RCRA Facility Investigation/Remedial Investigation (RFI/RI) and to support the following objectives:

1. Evaluation of the nature and extent of contamination related to the $716-\mathrm{A}$ MSSB;

2. Preparation of a baseline risk assessment;

3. Evaluation of whether potential contamination in the groundwater is stratified and, if so, whether different levels of contamination can be attributed to the 716A MSSB; and

4. Preparation of a treatability study/feasibility study report.

This work plan is organized into nine chapters. Chapter 1 , Introduction, outlines the regulatory framework, and provides a description and history of the A-Area. Chapter 2, Preliminary Unit Evaluation, is a description of the regional setting and the environmental setting specific to the A-Area including physiography, climate, geology, ecology, and soils. Chapter 3, Conceptual Site Model and Survey of Historical Data, presents a summary of existing data. The identification of possible receptors, the conceptual site model, and a preliminary review of potential treatment technologies are also presented in Chapter 3. Chapter 4, the Unit Assessment, outlines the proposed environmental sampling in the A-Area. The schedule for RFI/RI activities and document submittals is provided in Chapter 5 .

The unit specific health and safety plan will be written as specified in Chapter 6 . The Quality Assurance and Quality Control procedures to be used during investigation of the MSSB at SRS are contained in the following WSRC documents which are referenced in Chapter 7:

- Quality Assurance Manual (U), 
- Hydrogeologic Data Collection Procedures and Specifications $(U)$, and

- Environmental Monitoring Section Environmental Geochemistry Group Program Overview.

Data management will follow the guidelines in the Environmental Monitoring Section Environmental Geochemistry Group Program Overview as described in Chapter 8. Chapter 9 is a list of references used to prepare this document.

\subsection{REGULATORY BACKGROUND}

\subsubsection{RCRA Facility Investigation Program}

The U.S. Department of Energy (DOE) Savannah River Operations Office, Savannah River Site (SRS), Aiken, South Carolina, manages waste materials that are regulated under the Resource Conservation and Recovery Act (RCRA) of 1976, a comprehensive law requiring stringent management of hazardous waste and the Hazardous and Solid Waste Amendments (HSWA), passed in 1984 to further augment the 1976 requirements. Certain activities conducted at some SRS waste units require compliance with operating or post closure permits issued in accordance with RCRA. These regulated units are those surface impoundments, landfills, and waste piles (collectively termed "land disposal units") which have received hazardous waste since November 19, 1980, and which require RCRA operating or post-closure permits. The SRS has received a RCRA permit from the South Carolina Department of Health and Environmental Control (SCDHEC). Part V of the permit mandates that SRS establish and implement a RCRA Facility Investigation (RFI) Program to fulfill the requirements of HSWA Section $3004(\mathrm{u})$.

HSWA Section 3004 (u) mandates the investigation and corrective action at nonregulated units. These non-regulated units have been termed Solid Waste Management Units (SWMUs) and may include any activity where hazardous constituents remain uncontrolled and could potentially be released to the environment. Section V.A.1 of the SRS RCRA Permit lists 65 SWMUs that were identified by the United States Environmental Protection Agency (EPA) Region IV through the RCRA Facility Assessment process. The permit mandates that these 65 SWMUs be further investigated to determine the actual or potential impact of each unit on the environment. The 716-A MSSB is a SWMU that requires investigation in accordance with the RCRA permit. In addition, in 1994, SRS was directed by SCDHEC to process these SWMUs as integrated RCRA/Comprehensive Environmental Response, Compensation, and Liability Act (CERCLA) units.

\subsubsection{CERCLA Remedial Investigation Program}

On December 21, 1989, SRS was included on the National Priorities List (NPL). A facility included on the NPL is subject to the provisions of CERCLA. In accordance 
with Section 120 of CERCLA, the U.S. DOE has negotiated a Federal Facility Agreement (FFA) with the U.S. EPA and SCDHEC to coordinate cleanup activities at SRS into one comprehensive strategy. Public participation requirements are listed in Sections 113 and 117 of CERCLA. These requirements include the establishment of an Administrative Record File that documents the selection of cleanup alternatives and provides for review and comment by the public of those alternatives. The SRS public information plan (DOE, 1994) is designed to facilitate public involvement in the decision-making processes for permitting, closure, and the selection of remedial alternatives. It addresses the requirements of CERCLA, RCRA, and the National Environmental Policy Act (NEPA).

The public information plan is available to the public in information repositories located in communities near the SRS. In addition to the public information plan, the public will have access to the Administrative Record File through these repositories.

Unit-specific work plans, such as this one, will be part of the Administrative Record File and will be available to the public: Information repositories have been established at DOE's Public Reading Room located at the University of South Carolina Aiken campus in Aiken, South Carolina, and the Thomas Cooper Library in Columbia, South Carolina. A notice will be published in local newspapers when information is being compiled regarding the investigation and cleanup of the MSSB. Additional repositories may be added and/or locations changed to better meet the needs of the public.

The RFI Program Plan (WSRC, 1989) was developed by SRS to provide guidance and delineate standard procedures for facility investigations at SRS. The RFI Program Plan was expanded to include CERCLA hazardous substances and has been retitled the RCRA Facility Investigation/Remedial Investigation Program Plan (RFI/RI-PP) (WSRC, 1993a).

\subsection{BACKGROUND HISTORY}

The Savannah River Site (SRS) is located in south-central South Carolina and occupies an area of approximately 300 square miles (197,000 acres) (Figure 1-1). Construction of the SRS was initiated by the United States Government in 1950. The main function of the SRS has been to produce nuclear materials for national defense. The SRS is part of the United States Department of Energy (DOE) Nuclear Weapons Complex. It is owned and operated by the DOE.

The A-Area, located in the northwestern section of the SRS, has served as an administrative and research center. It is located atop a wide, flat ridge in the drainage basin of the Savannah River and its tributaries. 
The location of major SRS facilities is shown in Figure 1-2. The facilities for fabricating fuel and target elements for SRS reactors are located in the M-Area. The Savannah River Technology Center (SRTC), adjacent to A-Area, is a processdevelopment laboratory that supports production operations. The administration facilities of SRS are located in A-Area along with the motor shops/motor pool facilities. The A-Area includes several RCRA/CERCLA units, three are shown on the map in Figure 1-3: the MSSB, the A-Area Rubble Pile and the A-Area Coal Pile Runoff Containment Basin.

\subsubsection{6-A Motor Shops Seepage Basin}

The 716-A MSSB was constructed and placed in service in 1977 to receive liquid waste from the 716-A Motor Shops oil/water separator. The 716-A MSSB was designed and constructed as an unlined seepage basin. The basin measures 207.0 feet long, 35.1 feet wide, and 6.6 feet deep, (Huber et. al., 1987) with total operational capacity of approximately 43,000 cubic feet or 322,000 gallons. The seepage basin is surrounded by a berm 6.6 feet high on three sides. The fourth side (the northwest side) is also 6.6 feet high and faces a railroad track. The wastewater flowed into the basin from the northwest through an influent pipe from the Motor Shop (Building 716-A). The liquid wastes seeped naturally into the soil beneath the basin. The basin has not been closed, but all discharges to the basin were terminated in 1983 and the influent lines from the Motor Shops were capped (Huber et. al., 1987). Effluent discharges from the Motor Shops included wastewater with trace amounts of engine oil, grease, kerosenes, ethylene glycol, and soapy water. A ramp was built into the eastern end of the basin in 1988 (WSRC, 1990) to facilitate soil sampling. At present, the basin collects rainwater during periods of heavy precipitation. The berm of the basin is grown over with grass, weeds, and small trees. Several photographs of the 716-A MSSB are included in Appendix A.4.

\subsection{GENERAL RFI/RI INVESTIGATION PROCEDURES}

The RFI/RI-PP (WSRC, 1993a) delineates standard procedures for RCRA/CERCLA unit investigations. A unit-specific plan will be prepared prior to initiating field work to address safety, health, and emergency response procedures. Quality assurance/quality control is referenced in Chapter 7 and will follow WSRC guidance, (1993b, 1994a, and WSRC, 1995a). Data management will be performed in accordance with the Environmental Monitoring Section Environmental Geochemistry Group Program Overview (WSRC, 1995a). Activities include a review of the results of the specific investigatory phases within the RFI/RI process. These reviews enable the SRS RFI/RI Program Team to determine the extent of any further investigations necessary to adequately characterize the RCRA/CERCLA unit with respect to the presence and impact of hazardous substances. Each of these phases contains activities that address specific items to be evaluated. The investigatory phases and the corresponding considerations are as follows: 
- Preliminary Unit Evaluation - determine if hazardous substances have been received at the RCRA/CERCLA unit;

- Unit Screening - confirm the presence or absence of subsurface hazardous substances above background concentrations and, if confirmed, determine if hazardous substances have been released to environmental media from the RCRA/CERCLA unit;

- Unit Assessment - evaluate the extent of hazardous substances in the soil at and near the RCRA/CERCLA unit; and

- Groundwater (and Ambient Air, if necessary) Assessment Sampling - evaluate the extent of hazardous substances in specific media at the RCRA/CERCLA unit.

For the MSSB, the preliminary unit evaluation and the unit screening phase have been completed. This document presents the work plan for assessment of the nature and extent, if any, of contaminant migration from the site. Data collected will be used to prepare a baseline risk assessment that analyzes the risks posed by the unit to both human health and the environment. These data will also assist in identifying and evaluating remediation alternatives.

A Conceptual Site Model (CSM) has been prepared for the unit along with Data Quality Objectives (DQOs) and Remediation Objectives and Assessment Endpoints (see Chapter 3). Comparison of the CSM with the DQOs has resulted in a series of data gaps which must be filled to achieve the Remediation Objectives and Assessment Endpoints (see Table 4.1 in Chapter 4). The CSM will be modified, as necessary, based on the findings of the RFI/RI. 


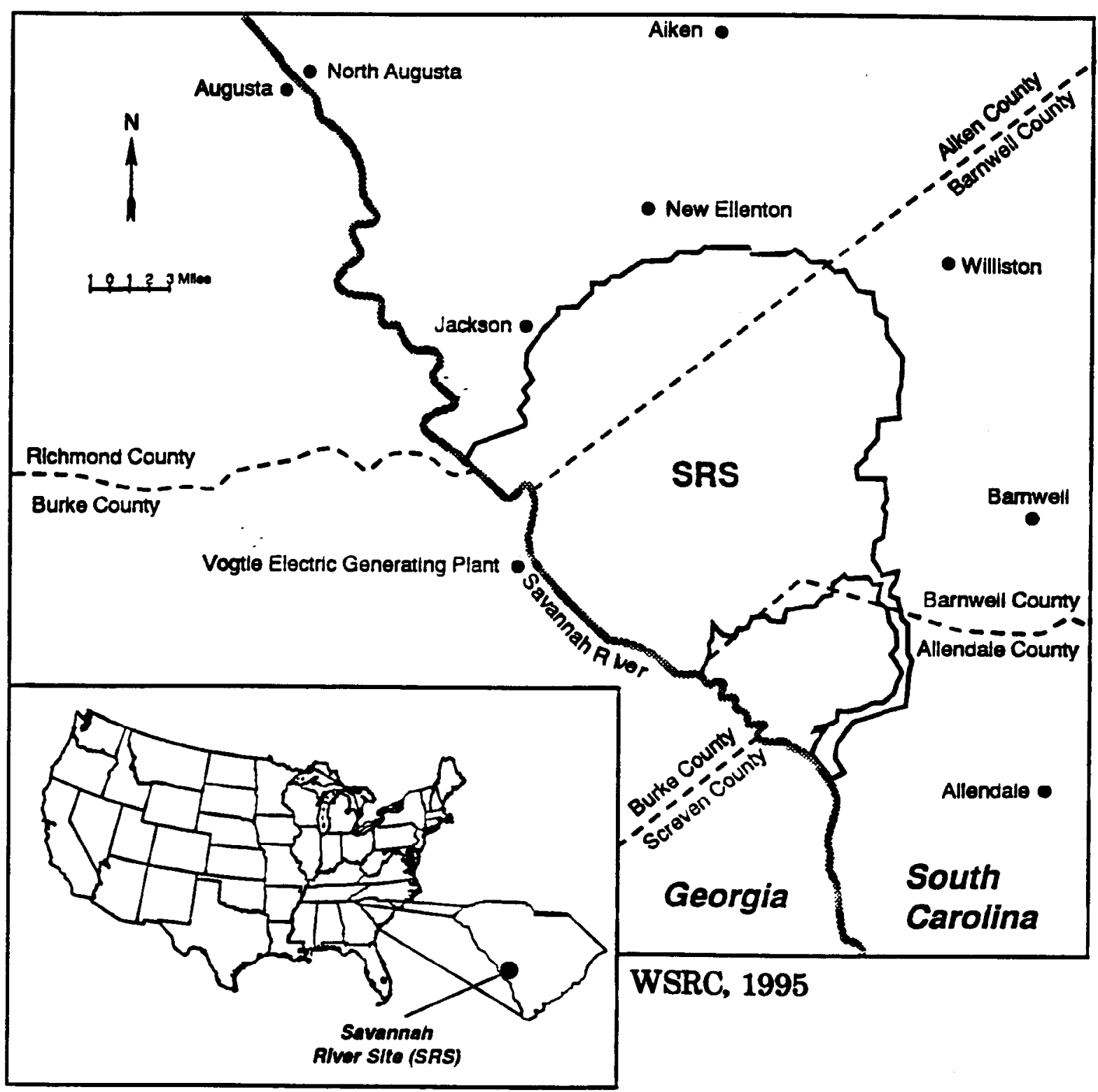

Figure 1-1 LOCATION OF SAVANNAH RIVER SITE IN SOUTH-CENTRAL SOUTH CAROLINA 


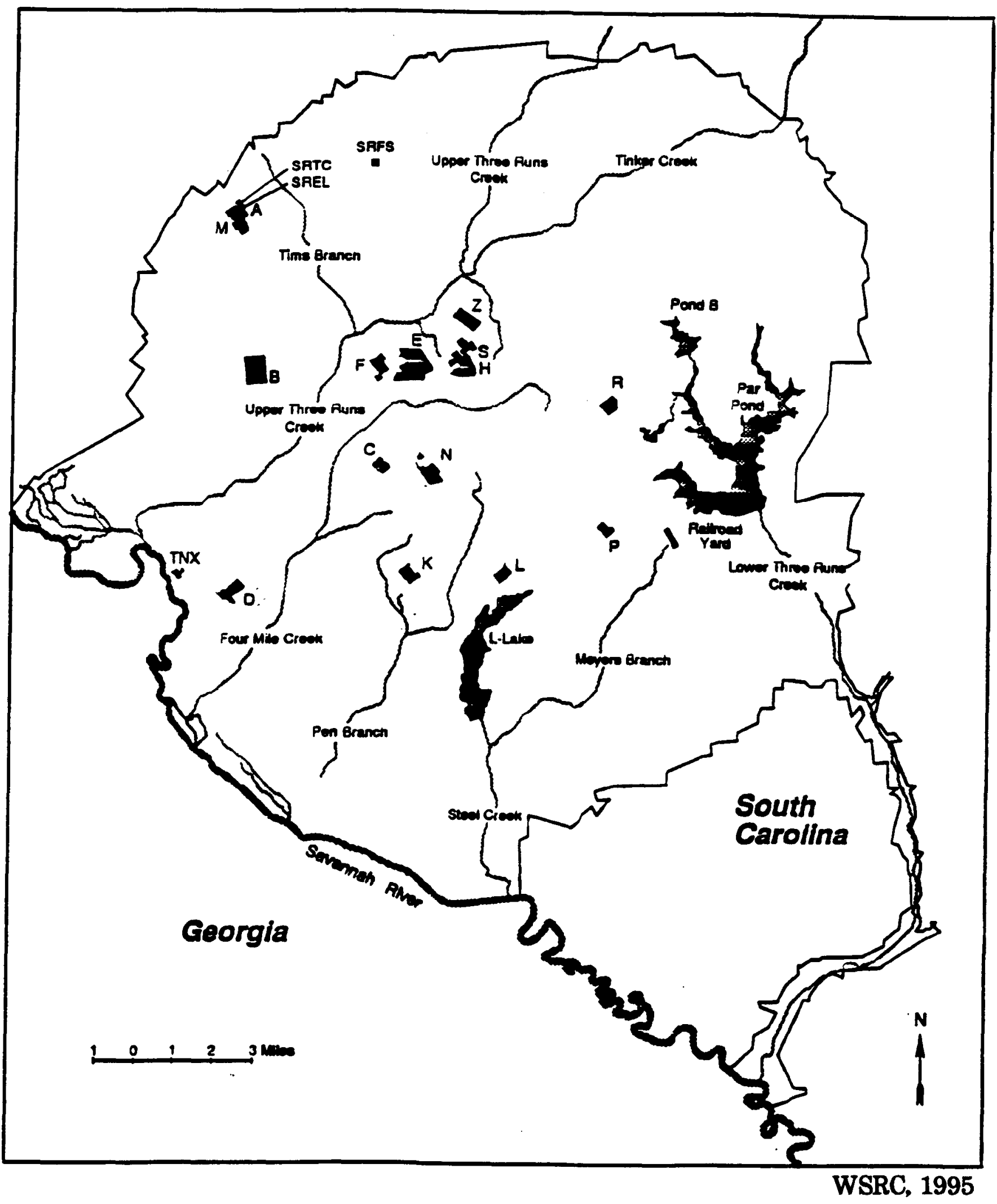



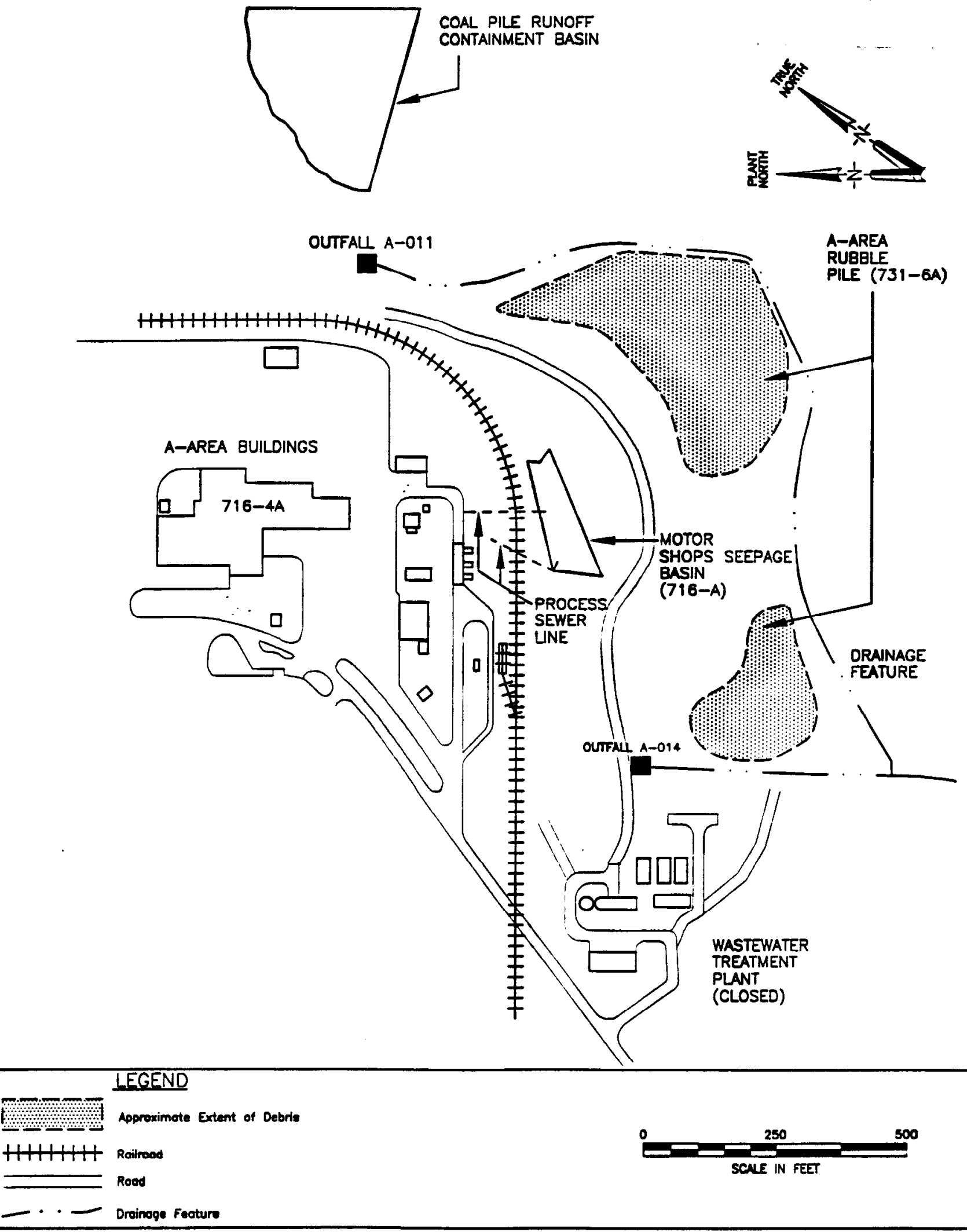

Figure 1-3 MOTOR SHOPS SEEPAGE BASIN LOCATION MAP 


\section{CHAPTER 2 \\ PRELIMINARY UNIT EVALUATION RESULTS}

\subsection{INTRODUCTION}

The first step to determine if a hazardous substance has been released from a RCRA/CERCLA unit consists of a preliminary unit evaluation. The primary goal of the preliminary evaluation is to determine if an unacceptable risk to human health and/or environment may exist at a unit, and if so, what course of action is appropriate to reduce these risks to an acceptable level. Specific procedures typical to most waste unit investigations and designed to provide the basis for the determination of the above criteria are outlined in the following sections.

\subsection{PRELIMINARY UNIT EVALUATION PROCEDURES}

A review of existing literature and information from the 716-A Motor Shops Seepage Basin (MSSB) was conducted and included, but was not limited to, the following:

- the RCRA/CERCLA unit disposal history and unit area characteristics;

- physical and chemical characteristics of the waste (hazardous and nonhazardous) known to be managed at the unit;

- the general hydrogeologic conditions of the RCRA/CERCLA unit and the current environmental setting; and

- any previous sampling and/or monitoring data for the unit.

\subsubsection{Existing Literature and Information}

The documents listed below were reviewed during the Preliminary Unit Evaluation of 716-A MSSB.

- Westinghouse Savannah River Company, 1990. RCRA Facility Investigation/Remedial Investigation Plan for the 716-A MSSB, (WSRC-RP-90581).

- Pirkle, Robert J. and D. J. Masdea, 1993. Soil Gas Investigations near the A-Area MSSB including Areas 716A and 731-A Savannah River Site Microseeps, University of Pittsburgh Applied Research Center.

- Westinghouse Savannah River Company, 1993a. RCRA Facility Investigation/Remedial Investigation Program Plan (WSRC-RP-89-994). 
Once literature was reviewed, the "RCRA/CERCLA Unit Literature Review Checklist" was completed. This checklist presents RCRA/CERCLA unit data and information that are specific to each individual environmental medium. Copies of the completed checklist appear in Appendix A.1 of this document.

\subsubsection{RCRA/CERCLA Unit Reconnaissance}

Following a review of existing data and information, a unit reconnaissance was performed. The unit reconnaissance (field observation and characterization) was conducted to further assess the following field conditions:

- environmental setting,

- source characterization (RCRA/CERCLA unit conditions and waste characteristics), and

- waste release potential (for each environmental medium).

The completed "Unit Reconnaissance Field Data Sheets" list the unit-specific factors that were considered during the actual reconnaissance and provide appropriate written documentation of field observations. The Unit Reconnaissance Field Data Sheets for the 716-A MSSB are provided in Appendix A.2.

\subsection{PRELIMINARY UNIT EVALUATION RESULTS}

Information regarding the current unit condition has been listed on the Literature Review Checklist and the Unit Reconnaissance Field Data Sheets. This information is summarized below in Sections 2.3.1 through 2.3.3.

\subsubsection{RCRA/CERCLA Unit Disposal History and Waste Characteristics}

The 716-A MSSB was constructed in 1977 as an unlined seepage basin. The basin measured approximately $207 \mathrm{ft}$ long, $35 \mathrm{ft}$ wide, and $6.6 \mathrm{ft}$ deep, with total operational capacity of approximately $43,000 \mathrm{ft}^{3}$ or 322,000 gallons. The 716-A MSSB began receiving wastewater from the northwest through an influent pipe from the Motor Shops (716-A). A second influent pipe was discovered (from the northwest) during a site visit conducted during the development of this work plan. The Motor Shops wash water and waste passed through an oil/water separator before being discharged to the basin. Effluent discharges included wastewater with trace amounts of engine oil, grease, kerosene, ethylene glycol, and soapy water. The basin has not been closed, but is inactive. All discharges to the basin were terminated in 1983 and the influent lines from the Motor Shops were capped. The basin currently acts as a wet-weather pond which contains water after rainfalls and is covered with natural vegetation, including bushes and grasses. 


\subsubsection{Ecological Setting}

The MSSB is located at the periphery of an active industrialized area. The surrounding areas are characterized by old field and early successional forest communities.

Vegetation in the basin and portions of the surrounding area consists of young pines (Pinus spp.) and oaks (Quercus spp.), honeysuckle (Lonicera spp.), blackberry (Rubus spp.), goldenrod (Solidago spp.), various ferns, and grasses. Upland woody species (young trees and shrubs) present in the basin suggest that it has not held runoff for long periods in the recent past. Typically such species are not tolerant of long-term inundation. Animal species which may occur in the area include rabbit (Sylvilagus spp.), white-tailed deer (Odocoileus virginianus), quail (Colinus virginianus), other birds, small mammals, reptiles, and amphibians.

\subsubsection{Environmental Setting}

Regional information about SRS was reviewed to develop a more complete environmental setting of the 716-A MSSB. This information was obtained from existing documents that describe geologic and hydrogeologic properties within specific areas of SRS. The unit-specific environmental setting is presented in the following sections.

\subsubsection{Physiographic Setting}

SRS occupies an area of approximately 300 square miles of the Atlantic Coastal Plain, primarily on the Aiken Plateau (Figure 2-1). The Aiken Plateau is bounded by the Piedmont Physiographic Province on the north, and by the Savannah and Congaree Rivers on the west and east, respectively. The plateau slopes southward from elevation 650 feet above mean sea level (msl) at the Fall Line to its southern boundary, which is marked by a regional break in slope at an approximate elevation of 250 feet msl. The surface of the Aiken Plateau is characterized by broad interfluvial areas dissected by narrow, steep-sided stream valleys.

Nearly all of SRS lies within the Savannah River drainage basin, with the Savannah River forming the southwestern boundary of SRS. Major tributaries to the Savannah River that flow southwestward across SRS are Upper Three Runs Creek, Tinker Creek, Fourmile Branch, Pen Branch, Steel Creek, and Lower Three Runs Creek (Figure 2-2). Ground surface elevations at SRS range from approximately 70 feet msl at the mouth of Lower Three Runs Creek to over 400 feet msl on the plateau (WSRC, 1995b).

The A-Area is located in the northwestern corner of the SRS and serves as a main administrative hub for the site. The 716-A MSSB is located in A-Area south of the railroad tracks near the automotive shop. The elevation varies between $340-350 \mathrm{ft}$ msl and slopes gently to the southwest. A small drainage feature runs through the area approximately 300 feet to the east of the MSSB. The headwater is an NPDES permitted outfall (A-011). This drainage feature turns southwest and discharges into a tributary of Tims Branch. Tims 
Branch discharges into the Upper Three Runs Creek located $3.5 \mathrm{mi}$ to the southeast. There is no surface water connection between the MSSB and the drainage feature.

\subsection{GEOLOGY AND HYDROGEOLOGY OF THE SRS}

The following is a summary of the general stratigraphic sequence and known hydrogeology at SRS. This information is derived from several documents including Marine and Bledsoe (1984), Bledsoe, et al., (1990), Aadland and Bledsoe, (1990), Aadland et al., (1992), Fallaw and Price, (1994), Lewis and Aadland (1994), and WSRC (1995c).

\subsubsection{Geology/Stratigraphic Sequence}

The stratigraphic sequence at the SRS is shown in Figure 2-3. The SRS is underlain by a seaward-thickening wedge of unconsolidated and semi-consolidated fluvial, deltaic, and marine sediments. The sedimentary wedge thickens from approximately 650 feet at the northern boundary of SRS to approximately 1200 feet at the southern boundary. These sediments range in age from Late Cretaceous to Holocene. The Late Cretaceous sediments rest directly on saprolite derived from underlying crystalline basement rocks of Precambrian/Paleozoic age, or on Triassic-age sediments which occupy the fault-bounded Dunbarton Basin.

\subsubsection{Paleozoic and Triassic}

Data from a few deep wells and coreholes indicate that the Paleozoic crystalline basement rock is composed of chlorite-hornblende schist, hornblende gneiss, and lesser amounts of other types of crystalline rock. The Triassic Dunbarton Basin sediments are composed of pooriy sorted conglomerate, sand and clay, and are generally dark red in color.

\subsubsection{Cretaceous}

The Cretaceous sediments comprise the Lumbee Group, which includes four formations. In ascending order, these are the Cape Fear, Middendorf, Black Creek, and Steel Creek Formations. The dip of the upper surface of the Lumbee Group is to the southeast at approximately 21 feet/mile across the SRS. The Cape Fear Formation nonconformably overlies the weathered and eroded surface of the basement complex, and consists of a heterogeneous sequence of clays, sandy clays, and clayey sands. The Middendorf Formation unconformably overlies the Cape Fear Formation and consists of medium to coarse grained, poorly sorted, angular, tan to yellow sands. The Black Creek Formation consists of clay laminae interbedded with layers of fine-grained clayey sand. The Steel Creek Formation consists of medium to coarse, yellow to gray sand interbedded with clay.

\subsubsection{Paleocene and Early Eocene}

Paleocene and Early Eocene sediments of the Black Mingo Group overlie the Cretaceous sediments. The upper surface dips to the southeast at about $16 \mathrm{feet} / \mathrm{mile}$ across SRS. At the SRS, the Black Mingo Group consists of the Lang Syne/Sawdust Landing, 
Snapp and Fourmile Formations. The Lang Syne/Sawdust Landing Formation is composed of two dark gray to black fining upward sand-to-clay sequences. It is unconformably overlain by the Snapp Formation in the southern part of the SRS, however, in the $\mathrm{A} / \mathrm{M}$ Area, the Snapp Formation is not present. In the $\mathrm{A} / \mathrm{M}$ Area the Lang Syne/Sawdust Landing Formation is overlain by the Fourmile Formation. The Fourmile Formation consists of white to brown, moderately well sorted, coarse to fine grained sands.

\subsubsection{Eocene}

Eocene sediments of the Orangeburg Group overlie the Black Mingo Group. The Orangeburg Group consists of the lower Middle Eocene Congaree Formation and the Upper/Middle Eocene Warley Hill and Santee Formations. Sediments of the Orangeburg Group are exposed at lower elevations in many places on and near SRS. The sediments thicken from approximately 100 feet at the northwestern SRS boundary to 160 feet near the southeastern boundary. The dip of the upper surface of the Orangeburg sediments is about 12 feet per mile to the southeast of the site. Downdip at the coast, the Orangeburg Group is about 325 feet thick.

Sediments of the Congaree Formation consists predominantly of well sorted, fine to coarse quartz sand. Thin, discontinuous clay layers occur locally near the middle and bottom of the formation. The sands are typically poorly sorted and vary in color from yellow to orange, tan, and green.

Fining upward sands of the Warley Hill Formation unconformably overlie the Congaree Formation. Silt and clay content increases and glauconite is more common in the Warley Hill Formation. The Santee Formation overlies the Warley Hill and is composed of sands, calcareous sands, clays, and limestone. The calcareous portion of the Santee Formation is absent in the A/M Area. "Green clay" beds in the interval are referred to in many SRS reports.

The Upper Eocene Barnwell Group, which overlies the Santee Formation, is subdivided into the Clinchfield, Dry Branch, and Tobacco Road Formations. The Clinchfield Formation is not present in the A/M Area. The Dry Branch Formation is subdivided into three members. The Griffins Landing Member is also not present in the A/M Area. The Irwinton Sand Member consists of moderately sorted sand with locally abundant clay layers. The Twiggs Clay Member is present at various stratigraphic intervals within the Dry Branch Formation, but it is not continuous over long distances. It has been called the "tan clay" in many SRS reports. The Twiggs Clay Member consists of thin, laminated clays and clayey sand. 
The uppermost Eocene unit is the Tobacco Road Formation, which consists of clayey, very fine- to medium-grained sands and sandy clays. The Miocene Upland Unit Formation was deposited in swales eroded into the underlying Barnwell Group. The Upland Unit consists of clayey, poorly sorted, feldspathic, angular, coarse-grained sand and sandy pebble zones. Cross-bedding is evident in outcrops.

\subsubsection{Hydrogeology of the SRS}

Two hydrogeologic provinces have been identified in the SRS, the Southeastern Coastal Plain hydrogeologic province and the underlying Piedmont geologic province (Aadland and Bledsoe, 1990). The hydrogeologic units of interest to this investigation are contained within the Southeastern Coastal Plant hydrogeologic province, which consists of unconsolidated Coastal Plain sediments of Late Cretaceous and Tertiary age. The Coastal Plain sediments constitute a multi-layered hydrologic system.

The Southeastern Coastal Plan hydrogeologic province is underlain by the Appleton Confining System. The Appleton Confining System correlates generally with the Cape Fear Formation (Fig. 2-3) and represents the bottom of the Cretaceous section at SRS. Because of its fine-grained and clayey character, the Cape Fear Formation is an effective confining unit separating the water-bearing units of the Cretaceous section from the basement complex, which contains water of poor quality in Paleozoic crystalline rocks and Triassic-age sediments. The Southeastern Coastal Plan hydrogeologic province in the SRS has been divided into three aquifer systems separated by two confining systems (WSRC, 1995c) (Figure 2-3).

In descending order, the aquifer systems in the SRS include the Floridan aquifer system, the Dublin aquifer system, and the Midville aquifer system. The Floridan aquifer system is separated from the underlying Dublin aquifer system by the Meyers Branch Confining System. The Dublin aquifer system is separated from the underlying Midville aquifer system by the Allendale Confining System.

Within the A-Area, approximately $30 \%$ of precipitation, or $15 \mathrm{in} . / \mathrm{yr}$, enters the groundwater system (Cahill, 1982). Recharge for the A-Area predominantly infiltrates and recharges the Steed Pond Aquifer, and the groundwater discharges as surface water to Tim's Branch, Upper Three Runs Creek, and the Southwest Swamps (Marine and Bledsoe, 1984). The Crouch Branch Aquifer receives recharge from an outcrop area approximately 2.5 miles north of the A-Area and from the overlying Steed Pond Aquifer through the Crouch Branch confining Unit. Discharge from the Crouch Branch Aquifer occurs to the southwest along the Savannah River (Lewis and Aadland, 1992).

Because of an apparent overall strong potential for vertical movement of groundwater throughout the A-Area, the thickness, horizontal continuity, and extent of the local confining units and zones will control the overall velocity and direction of groundwater within the AArea. Hydrostratigraphic interpretations indicate that the "green clay" confining zone, 
which separates the M-Area Aquifer zone and the Lost Lake Aquifer zone, thins in a northerly direction. In addition, the Crouch Branch Confining Unit thins in a similar fashion toward the northern portion of the A-Area. This hydrostratigraphic condition allows groundwater to penetrate deeper into the underlying units.

As indicated in Figure 2-4, in the northern portion of the SRS, which includes the A/M Area, the confining units thin out and the three aquifer systems coalesce to form one aquifer system, called the Floridan - Midville aquifer system.

\subsection{HYDROGEOLOGIC SETTING OF THE A-AREA}

The MSSB is known to have received hazardous substances. However, to assess whether these substances have remained within the Seepage Basin, it is necessary to determine (1) the pathways that constituents may have followed during possible migration from the waste site, and (2) if potentially hazardous substances exist along these pathways. Transport of substances within groundwater is one of the means of substance migration away from the unit. The following sections describe the hydrogeologic characteristics in the A-Area and the likely groundwater flow paths.

\subsubsection{Physiography and Drainage}

The MSSB is located in the A-Area south of the railroad tracks. Two other RFI/RI units, the A-Area Coal Pile Runoff Basin and the A-Area Rubble Pile are located nearby. In general, the ground slopes to the southeast in the direction of Tims Branch, approximately 4000 feet away, which is the closest natural surface water drainage. The Seepage Basin is located at an elevation of approximately 350 feet msl on the side of a steep man-made slope. Approximately 200 feet south of the A-Area Rubble Pile the slope steepens to form an erosional ravine leading to Tims Branch. This unnamed tributary to Tims Branch receives nonprocess flow from two NPDES permitted outfalls in the area, A-011 and A-014.

\subsubsection{Surface and Subsurface Soils}

The soil types in and adjacent to the MSSB have been identified as Blanton Sand, Udorthent-Urban Land Complex, and Udorthent soils of the Hawthorne/Barnwell Formations (U. S. Soil Conservation Service, 1990). Udorthent soils are generally other standard soil series that have been disturbed through construction wark and/or pit filling operations. Udorthent soils show a wide composition variability consisting of gravels, sands, and clays.

Sediments encountered during a previous investigation (WSRC, 1990) consist of yellowish-brown, orange-pink, to reddish-brown, fine grained sand with clay. The sands are generally well-sorted, subangular, and moist. 


\subsubsection{Hydrogeology of the A/M Area}

In the $\mathrm{A} / \mathrm{M}$ Area the Floridan - Midville aquifer system is 557 feet thick and extends from the water table to the Appleton Confining System (WSRC, 1995c). The aquifer system is divided into three aquifers separated by two confining units (Figure 2-5). In descending order, the Steed Pond aquifer is underlain by the Crouch Branch confining unit which separates the Steed Pond aquifer from the Crouch Branch aquifer. The Crouch Branch aquifer is separated from the underlying McQueen Branch aquifer by the McQueen branch confining unit.

For the purposes of this investigation, the Steed Pond and Crouch Branch aquifers are of greatest interest. Both of the aquifers and the Crouch Branch confining unit are described in detail below based upon information contained in WSRC (1995c).

\section{Steed Pond Aquifer}

The Steed Pond aquifer is 97 feet thick and is divided into two zones in the A/M Area, the "M-Area" aquifer zone and the "Lost Lake" aquifer zone. The two zones are separated by the "green clay" confining zone as shown in Figure 2-5. Porosity and calculated permeability values for Steed Pond aquifer sands range from 25 to 41 percent (average 34 percent) and 2.4 to $489 \mathrm{ft} / \mathrm{d}$ (mean $75.6 \mathrm{ft} / \mathrm{d}$ ), respectively.

\section{"M-Area" Aquifer Zone}

In the $\mathrm{A} / \mathrm{M}$ Area, the "M-Area" aquifer zone extends from the water table (approximately 150 feet below land surface) to the "green clay" confining zone and consists of sands of the Santee and Dry Branch Formations. Recharge enters the "M-Area" aquifer through precipitation and infiltration. A potentiometric surface map of the "M-Area" aquifer zone in the A/M Area shown in Figure 2-6, indicates that the groundwater flow direction is to the west-northwest for the aquifer zone in the vicinity of the MSSB. Hydraulic conductivity values, based upon slug tests, range from 0.01 to $10.87 \mathrm{ft} / \mathrm{d}$ (average $2.19 \mathrm{ft} / \mathrm{d}$ ) (WSRC, 1995c). Horizontal hydraulic gradients for the aquifer zone have been calculated between $0.0034 \mathrm{ft} / \mathrm{ft}$ to $0.0068 \mathrm{ft} / \mathrm{ft}$.

The vertical groundwater flow velocity in the "M-Area" aquifer zone was estimated in WSRC (1995c) to be $0.284 \mathrm{ft} / \mathrm{d}$, while the horizontal groundwater velocity was estimated to be $0.119 \mathrm{ft} / \mathrm{d}$ flow in the vicinity of the MSSB. These estimates indicate that a greater potential exists for downward movement of groundwater in the aquifer zone than for lateral movement.

\section{"Green Clay" Confining Zone}

The "green clay" confining zone separates the "M-Area" aquifer from the underlying "Lost Lake" aquifer zone and ranges from 8 to 27 faet thick (average 17 feet) in the vicinity of the MSSB. The confining zone is composed of sands, silts, and clays of the Warley Hill Formation (Fallow and Price, 1992). 


\section{"Lost Lake" Aquifer Zone}

The "Lost Lake" aquifer zone is composed of undifferentiated sands of the Congaree and Fourmile Formations. The aquifer zone ranges from 55 to 86 feet in thickness (average 60 feet). A potentiometric map of the upper "Lost Lake" aquifer zone shown in Figure 2-7, indicates that the groundwater flow direction is to the southwest in the vicinity of the MSSB. A potentiometric map of the lower "Lost Lake" aquifer zone (Figure 2-8) indicates that the groundwater flow direction is also to the southwest in the vicinity of the MSSB.

Hydraulic conductivity estimates for the "Lost Lake" aquifer zone, based upon slug test data, range from 1.30 to $77.7 \mathrm{ft} / \mathrm{d}$ (average $18.9 \mathrm{ft} / \mathrm{d}$ ) (WSRC, 1995c). Horizontal hydraulic gradients for the aquifer zone in the vicinity of the MSSB have been determined to be $0.0027 \mathrm{ft} / \mathrm{ft}$.

\section{Crouch Branch Confining Unit}

The Crouch Branch confining unit separates the Steed Pond aquifer from the underlying Crouch Branch aquifer. In the $\mathbf{A} / \mathbf{M}$ Area the confining unit ranges in thickness from 0 to 81 feet and is composed of clays, silts, and sands of the Steel Creek, Lang Syne/Sawdust Landing, and Snapp Formations.

In the $\mathrm{A} / \mathrm{M}$ Area, the Crouch Branch confining unit is composed of three zones, the "upper clay" confining zone, the "middle sand" aquifer zone, and the "lower clay" confining zone.

\section{"Middle Sand" Aquifer Zone}

The "middle sand" aquifer zone ranges in thickness from 12 to 68 feet (average 33 feet) in the A/M Area and is composed of sands, silts, and clays of the Lang Syne/Sawdust Landing Formation. The potentiometric surface of the aquifer zone is shown in Figure 2-9 and indicates that the groundwater flow direction is to the southwest in the vicinity of the MSSB. Hydraulic gradients are estimated to be $0.005 \mathrm{ft} / \mathrm{ft}$ and hydraulic conductivity estimates, based upon slug test data, range from 4.10 to $80.51 \mathrm{ft} / \mathrm{d}$ (average $47.4 \mathrm{ft} / \mathrm{d}$ ).

\section{Crouch Branch Aquifer}

The Crouch Branch aquifer ranges in thickness from 152 to 180 feet in the A/M Area and is composed of sands of the Black Creek and Steel Creek Formations. It is the principal water-producing aquifer in the SRS.

The potentiometric surface of the Crouch Branch aquifer, shown in Figure 2-10, indicates that the groundwater flow direction in the vicinity of the MSSB is to the southwest. The horizontal hydraulic gradient for the aquifer is $0.0010 \mathrm{ft} / \mathrm{ft}$ in the $\mathrm{A} / \mathrm{M}$ Area and the hydraulic conductivity is estimated as $28 \mathrm{ft} / \mathrm{d}$ (WSRC, 1995c). 


\subsection{PRELIMINARY UNIT EVALUATION RESULTS}

Information regarding the current unit conditions has been listed on the Literature Review Checklist and the Unit Reconnaissance Field Data Sheet (Appendix A). Waste disposal records and sampling/monitoring data indicate that the 716-A MSSB has received hazardous waste. Therefore, according to the RFI/RI Program Plan, Section 4.4, a Unit Screening program was required to identify any areas of hazardous substance release to the soil or groundwater. The Unit Screening results are contained in Chapter 3.0. 
NORTH

CAROL INA
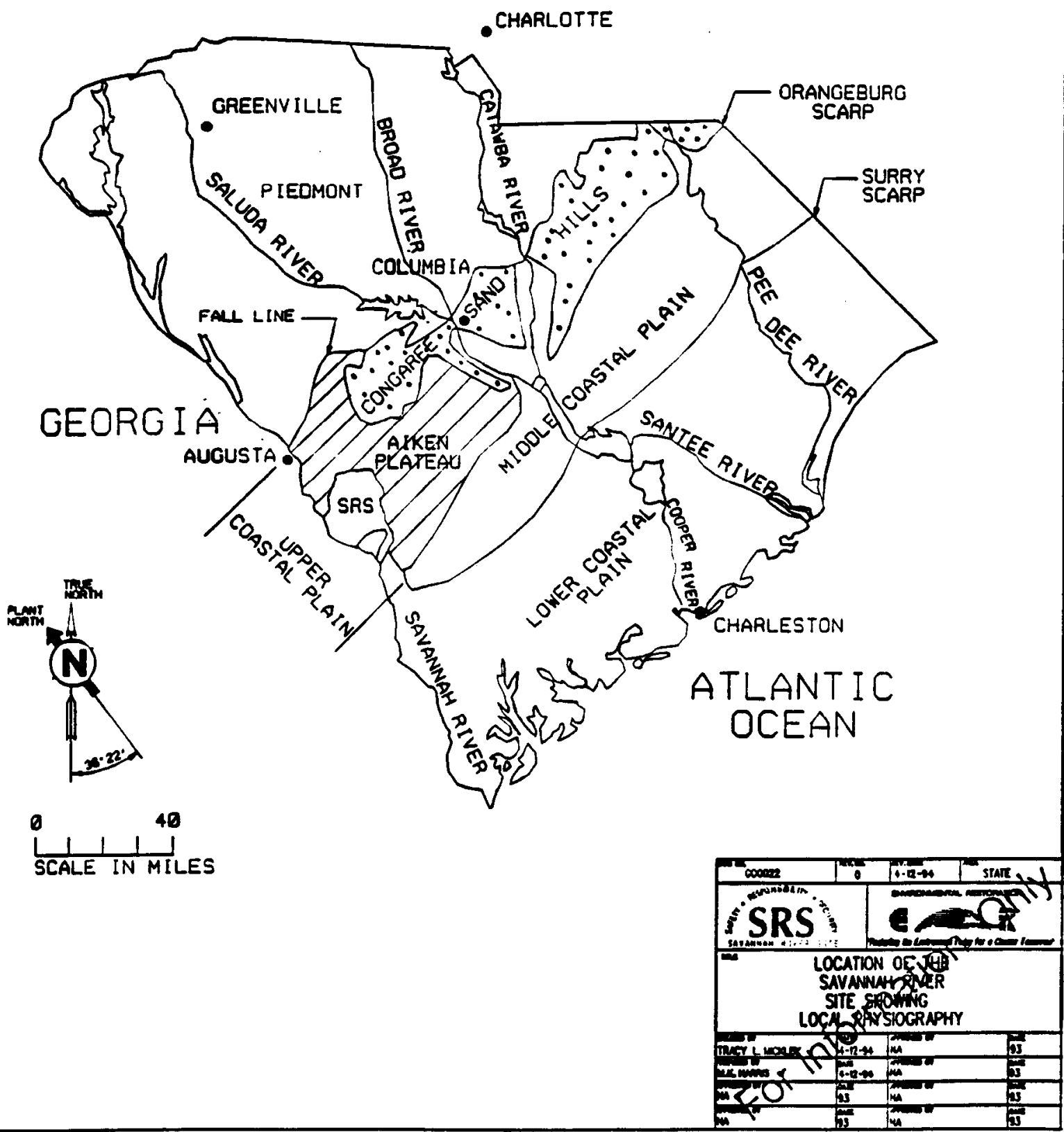

Figure 2-1 PHYSIOGRAPHIC SUBPROVINCES OF THE SOUTH CAROLINA COASTAL PLAIN 


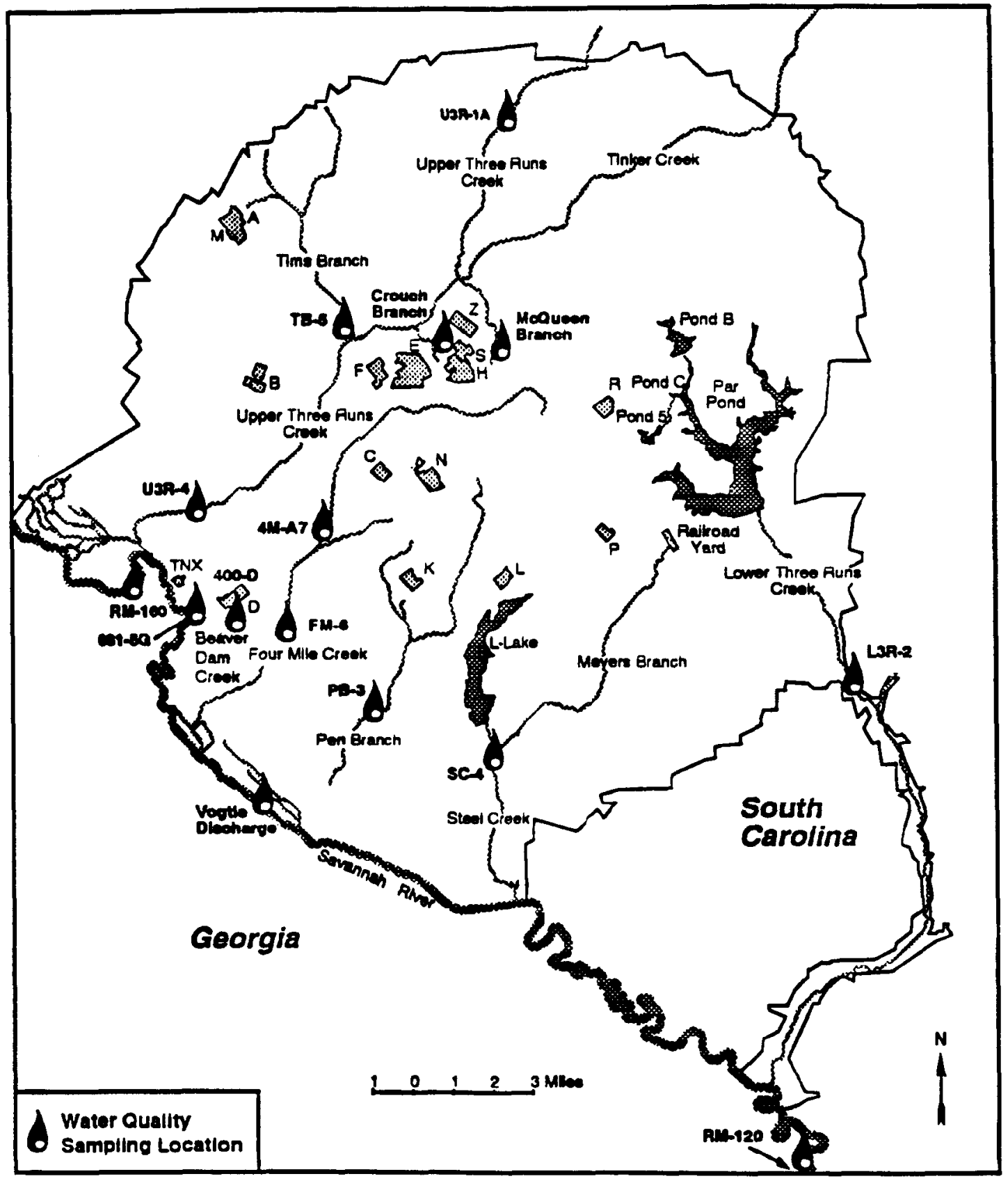

WSRC, 1995 



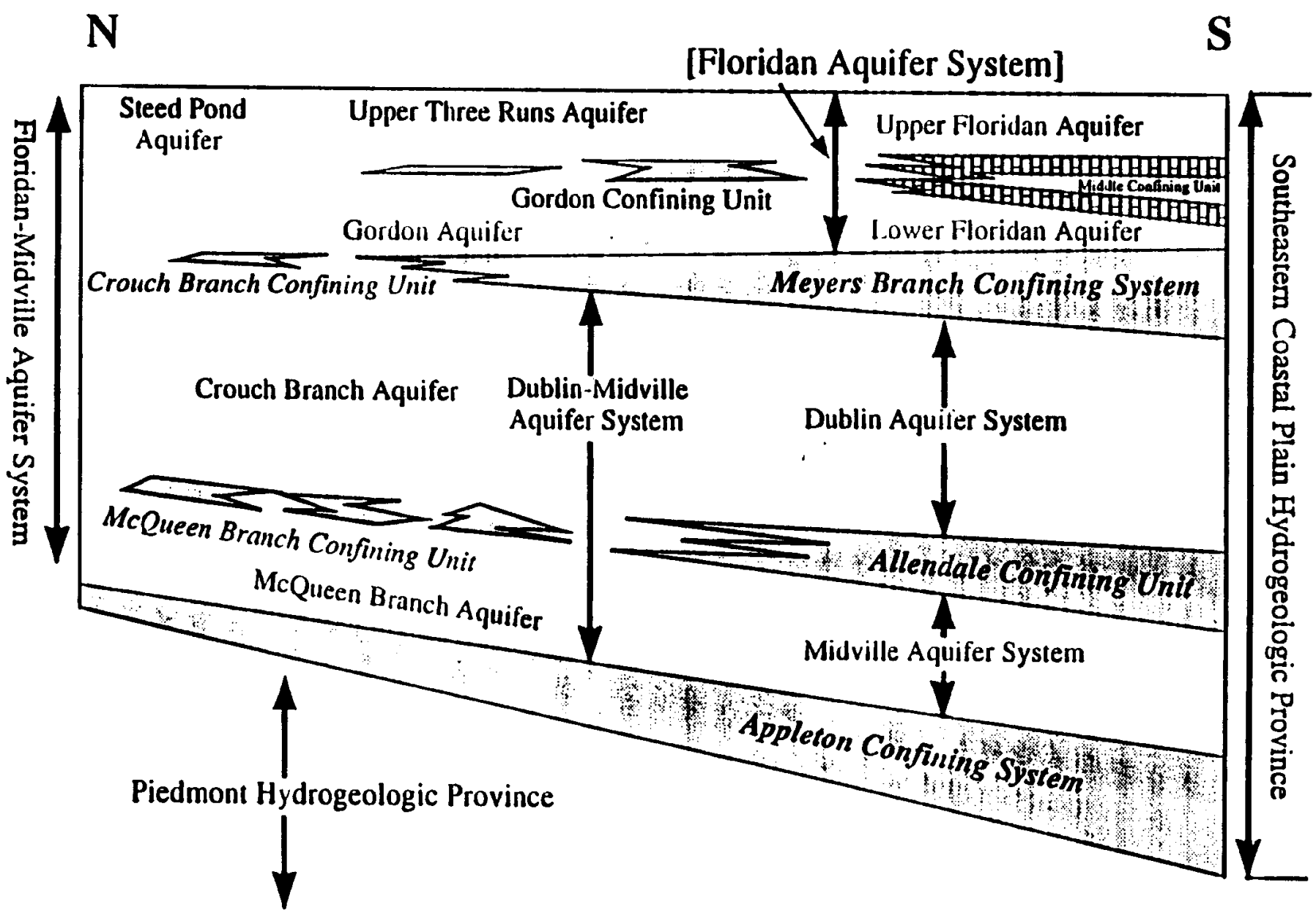




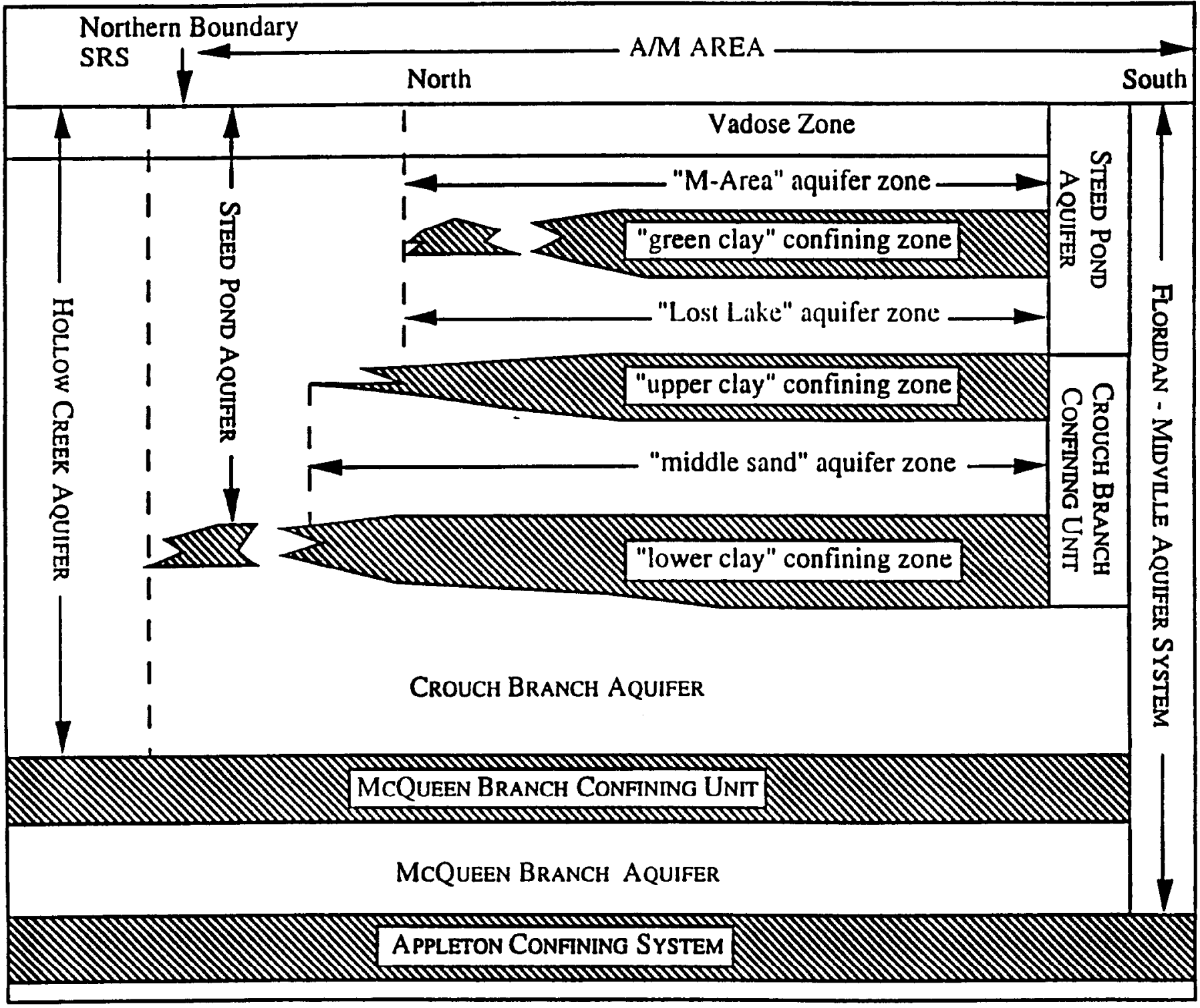

Source: Lewis and Aadland, 1992 


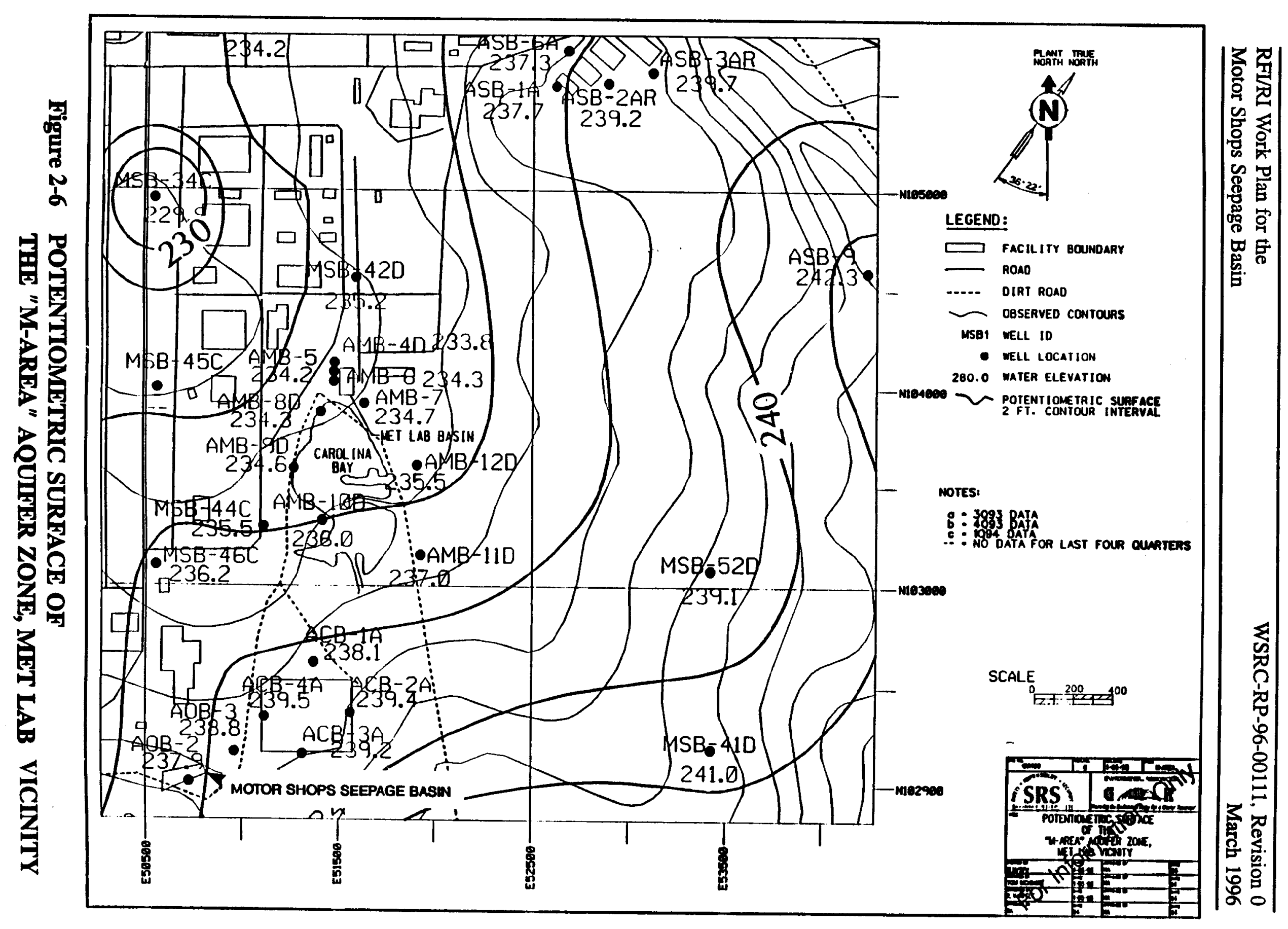




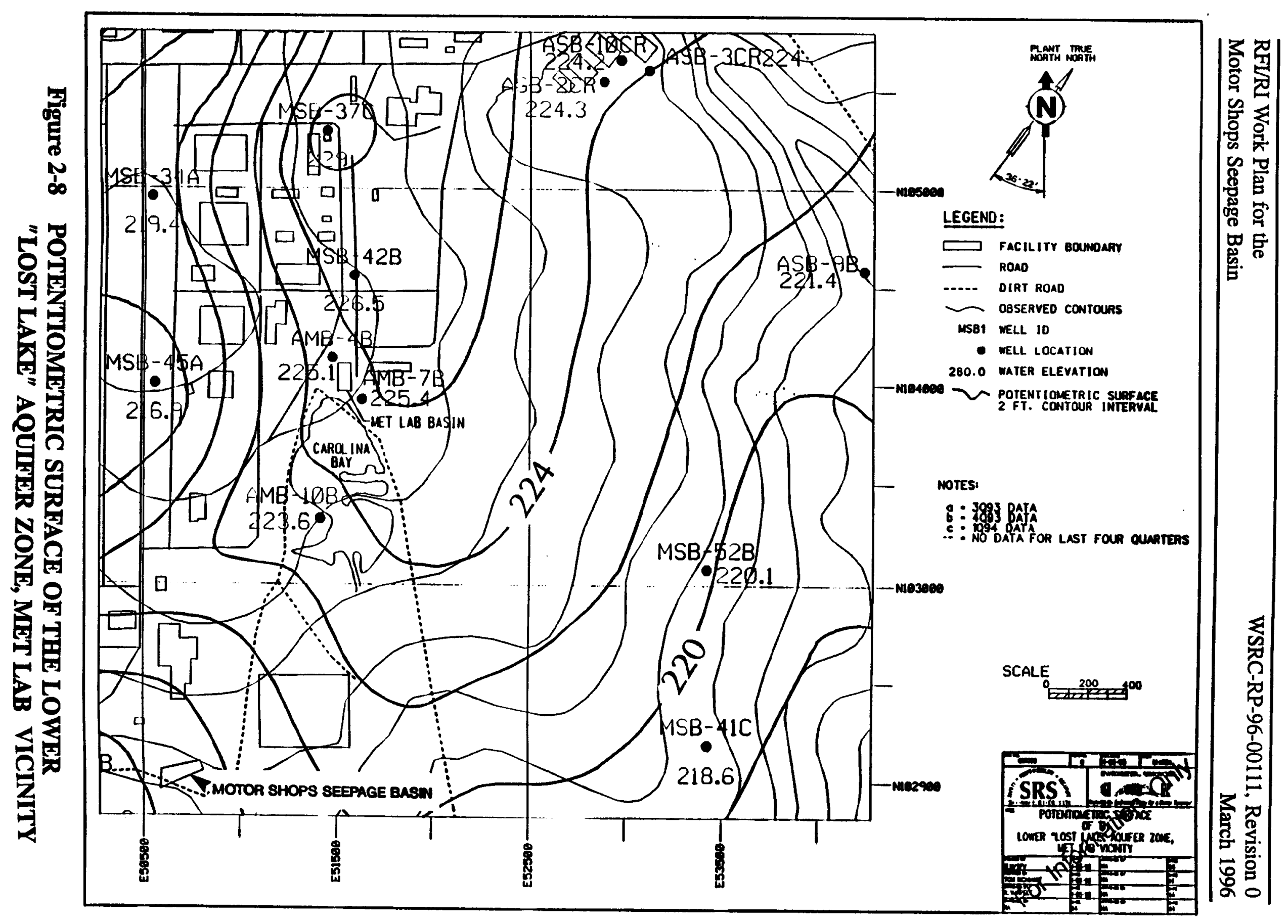




\section{CHAPTER 3 \\ CONCEPTUAL SITE MODEL AND SURVEY OF HISTORICAL DATA}

\subsection{INTRODUCTION AND OBJECTIVE}

This section provides the conceptual site model (CSM) for the 716-A Motor Shops Seepage Basin (MSSB) and presents historical data associated with the waste unit. The CSM represents the problem formulation step for preparing baseline risk assessments under CERCLA. The CSM identifies sources of contaminants, release mechanisms, the media of concern, and the receptors of interest.

The CSM integrates information about the extent and nature of hazardous substance releases from the MSSB. Existing data are evaluated and additional data needs are identified in accordance with the Data Quality Objective (DQO) process. These data will be used to prepare an RI report including a baseline human health and ecological risk assessment.

A CSM was prepared for the MSSB. Historical data are summarized and evaluated to identify the additional data required to evaluate the extent and nature of contamination and to support the baseline risk assessment and to evaluate remediation alternatives.

\subsection{CONCEPTUAL SITE MODEL}

Figure 3-1 is a graphical presentation of the mechanisms for release of contaminants from the primary sources. The emphasis is on pathways by which contaminants could migrate from the sources to receptors. The CSM identifies the source of contaminants, release mechanisms, the media of concern, and the receptors of interest for the unit. The CSM outlines the pathways for human and ecological receptors (Figure 3-2). Exposure pathways are summarized in Figure 3-3. Each of the seven generic components of the CSM is described below.

\subsubsection{6-A Motor Shops Seepage Basin Conceptual Site Model}

Primary sources of contamination. The primary source of contamination from within the MSSB is waste received from discharge pipes from the process sewer lines after it passed through an oil/water separator. The effluent included trace amounts of engine oil, grease, kerosene, ethylene glycol, detergents, and fuels (petroleum). 
Primary release mechanisms of source contamination. Hazardous wastes may have been released from the primary source of contamination by:

- Deposition of materials on the surface soils in or near the Seepage Basin and process sewer lines, and

- Infiltration and percolation of water through the Seepage Basin wastes and into subsurface soils.

Primary media impacted by the primary source of contamination. Environmental media impacted by release of source contamination may include:

- Surface soil in or near the Seepage Basin,

- Subsurface soils beneath the Seepage Basin contaminated via infiltration, percolation, and leaching, and

- Surface soil in or "near" the Seepage Basin contaminated via excavation or bioturbation bringing subsurface soils to the surface.

Secondary environmental release mechanisms. Environmental media may serve both as a reservoir via chemical bonding and biotic uptake, and as a secondary release mechanism for contaminants from the Seepage Basin. Secondary environmental release mechanisms may include:

- Fugitive dust and/or volatile emissions from surface soils,

- Biotic uptake occurring in the Seepage Basin, and

- Leaching of contaminants from subsurface soils into the groundwater.

Secondary media impacted. Contact with contaminated secondary media creates the points of exposure to be evaluated in the BRA. The secondary media to be evaluated include:

- Soil,

- Windblown dust and volatile emissions from soils at the Seepage Basin,

- Groundwater (used as potential future domestic water, human health only), and

- Biota.

Exposure routes. Exposure routes for human and ecological receptors include:

- Ingestion of contaminated media,

- Inhalation of windblown dust and volatile emissions,

- Dermal contact with contaminated media, and

- External radiation dose. 
Receptors. Human and ecological receptors are identified below.

Human receptors may include:

- Current on-unit workers,

- Hypothetical future on-unit residents, and

- Hypothetical future industrial on-unit workers.

Ecological receptors may include:

- Terrestrial ecological receptors (e.g., plants, earthworms, songbirds and other midlevel predators and top predators).

Aquatic receptors are not considered as viable due to the ephemeral nature of the Seepage Basin and the lack of other aquatic points of exposure.

\subsection{DATA QUALITY OBJECTIVES EVALUATION}

Data quality objectives (DQOs) are qualitative and quantitative statements that specify the quality and the extent of the data required to support the decision making processes during each investigation. Guidance for the DQO development process is contained in Data Quality Objectives Process for Superfund (EPA, 1994) and Planning for Data Collection: The Data Quality Objectives Process for Environmental Decisions, Draft Guidance (Neptune et al. 1991). DQOs are developed in three stages by a seven step process and presented on a DQO summary form.

\section{DQO Development}

DQOs are developed in the following three stages:

- Identify the types of decisions needed for the unit activity;

- Identify the types, quantity, and quality of data required to support these needed decisions; and

- Design a data acquisition program that will provide the required data with a sufficient level of quality.

\section{DQO Process}

The DQO process is divided into seven steps. These steps for DQO development for the 716-A MSSB are described in the following paragraphs. 


\section{Step 1 State the Problem}

This first step describes the problem by evaluating the site history including the existing data from previous investigations and determining the source and extent of the contamination and any potential exposure pathways.

Historical information indicates that liquid wastes from the 716-A Motor Shops oil/water separator may have contaminated the groundwater and soils within the basin area. Existing data from a soil gas survey and quarterly groundwater monitoring indicates that the groundwater and, potentially, the soil in the basin are contaminated with chlorinated solvents. Other facility data indicates that the basin may not be a major contributor to the chlorinated solvent groundwater contamination, that the major source may be upgradient in $A$ and $M$ Areas. The lack of soil data makes the determination of the source and impact, if any, the contamination has on the environment inconclusive. The groundwater within the Seepage Basin area may be impacted by upgradient sites such as the M-Area Seepage Basin, NPDES outfall A-011, and the Coal Pile Runoff Containment Basin. The M Area was the location of the fuel and target fabrication plant that operated from 1958 through 1985. It is located on a water table mound with radial flow in all directions. Wastes in the M-Area contain high concentrations of metals, nitrate, phosphate, sulfate, and solvents. Three monitoring wells at the northern (upgradient) boundary of the MSSB area have shown elevated levels of chlorinated solvents.

\section{Step 2 Identify the Decision}

The purpose of this step is to identify the decisions to be made. The main goals of the investigation of the 716-A MSSB are to determine the following:

- If contamination potentially hazardous to human health and/or the environment exists within the basin;

- If the basin is a source of the contamination; and

- If contamination has been released from the basin to surrounding media (e.g. soil, groundwater) and whether it is potentially hazardous to human health and/or the environment.

\section{Step 3 Identify the Inputs to the Decision}

The purpose of this step is to identify the environmental variables that impact decision rules. The decisions outlined in Step 2 will require the following:

- Collecting samples to establish background concentrations of chemicals of potential concern (COPCs) for comparison to on-unit concentrations; and

- Sampling, field screening and laboratory confirmation information to determine the nature and extent of contamination in the unit. 


\section{Step 4 Define the Boundaries of the Study}

The purpose of this step is to identify the spatial limits of the contamination and to determine the discrete area affected by the decisions. This step also identifies the population at risk and the impact on the present and future land use.

The spatial boundaries of the MSSB have been well defined and include the surface soil (0-1 ft), subsurface soil (1-4 ft), deep subsurface soils $(>4 \mathrm{ft})$, and groundwater. Human populations have been identified in Section 3.2.

\section{Step 5 Develop the Decision Rule}

The purpose of this step is to integrate the output from the previous steps of the DQO process into a statement that defines the conditions that would cause the decision maker to choose among the alternative actions.

If contamination is identified during Phase I, then characterization will continue during Phase 2 until the vertical and horizontal extent of contamination is adequately identified. Section 3.4 provides remediation objectives and risk assessment decision rules. Chapter 4 provides unit assessment specific decision rules.

Spatial statistics will be used to verify if the data was sufficient to characterize the site. If the data population is insufficient to make decisions, then additional characterizations may be required.

\section{Step 6 Specify Limits on Uncertainty}

The purpose of this step is to specify the acceptable decision error rates based on a consideration of the consequences of making an incorrect decision.

Statistical procedures outlined in the Guidance for Data Useability in Risk Assessment - Parts $A$ and B (EPA, 1992) are to be followed. The statistical tests will use a 90 percent confidence interval when comparing to background. This ensures that the sampling data as a whole is not judged to exceed the limits based on a few outliers that are not representative of the entire population.

The 95 percent upper confidence limit of the arithmetic mean or the maximum detect, whichever is lower, is employed in risk assessment calculations.

\section{Step 7 Optimize the Design for Obtaining Data}

The final step in the DQO process is to develop a sampling plan that takes into account the problems, key decisions, environmental variables, and how the spatial and temporal boundaries of the contamination and populations at risk will be identified. In addition, decisions will be made throughout the characterization regarding how uncertainty and tolerance for uncertainty will be identified. 
Chapter 4 outlines the characterization plan for the MSSB. This plan considers potentially impacted environmental media including contamination sources, soils, biota, and groundwater. The types and frequency of samples and their locations are clearly defined as well as the analytical methods to be used. Precision, accuracy, completeness, representativeness, comparability, and documentation of the characterization are specified in WSRC quality assurance procedures (see Chapter 7). The data management plan is contained in the WSRC Environmental Monitoring Section procedures (see Chapter 8). The safety, health and emergency response requirements of the work plan will be addressed in the unit-specific Health and Safety Plan.

\section{DQO Summary}

The data gaps identified by the DQO process for the MSSB are listed below:

- Data to establish background concentrations for chemicals of potential concern in surface soils, subsurface soils and groundwater;

- Data for determining the contaminants in the surface soil, subsurface soil, deep subsurface soil, and groundwater;

- Data for determining the local stratigraphy and groundwater levels and flow rate and direction; and

- Geotechnical data for determining remedial alternatives.

Data Levels

The analytical data quality levels for the data acquisition program are defined as follows:

- $\quad$ Screening analyses using simple portable instruments, such as photoionization detectors and more sophisticated portable analytical instruments, such as a portable gas chromatograph, and some chemical class specific field test kits. The simple portable instruments produce real-time, non-compound specific results that are typically used for health and safety monitoring and to make some preliminary comparisons during investigations. The more sophisticated instruments or field test kits produce data that may be used for determining extent of contamination, field screening of samples to be designated for laboratory confirmation analyses, and/or monitoring field operational parameters.

- Definitive analyses of organic and inorganic parameters using EPA procedures other than Contract Laboratory Program Statement of Work (CLP SOW) protocols (e.g. SW846 Test Methods for Evaluating Solid Wastes and Methods of Chemical Analysis of Water and Waste Water). This data quality level provides compound specific results with established accuracy and precision. 
A summary of the DQOs for the sampling and analysis of samples for the 716-A MSSB investigation is presented in Table 3.1. Appendix A-3 contains DQO worksheets.

\subsection{REMEDIATION OBJECTIVES AND ASSESSMENT ENDPOINTS}

The key decisions identified in the DQO process for the MSSB to be addressed by the BRA are stated in three remediation objectives for the human health risk assessment and five assessment endpoints for the ecological risk assessment. Remediation objectives and assessment endpoints are statements specifying the desired condition of the environment. Examples of desired conditions of the environment include safe for human consumption, protective of valued species, or ecosystem integrity. If these desired conditions are not present because of unit contamination, then it is possible that human health will be threatened, a valued species will be lost, or ecosystem integrity will be diminished. Valued species can be organisms with symbolic, commercial, recreational, or ecological importance. The U.S. Government's desire to protect some environmental components and functions have been codified into the nation's laws (e.g., Endangered Species Act) and policies (e.g., Executive Order 11990).

Remediation objectives and assessment endpoints are stated in terms of a level of adverse effect on a receptor from exposure to potentially hazardous site contaminants in one or more environmental media. The three human health remediation objectives and five ecological assessment endpoints along with the measurement endpoints and decision rules used to evaluate each are given below. The human health remediation objectives and ecological assessment endpoints are evaluated for unit contaminants that qualify as COPCs based on the results of the COPC screens in the human health and ecological risk assessments, respectively.

\subsubsection{Human Health Remediation Objectives}

One goal of remediation at the MSSB is to protect current and potential future human receptors. Three categories of potential human receptors have been defined:

- Hypothetical future on-unit industrial worker,

- Hypothetical future on-unit resident, and

- Current on-unit worker.

Potential routes of exposure to these receptors are defined in the CSM. The human health remediation objectives, measurement endpoints and decision rules for these receptors are discussed below.

Human Health Remediation Objective 1: No unacceptable adverse effects on hypothetical future industrial workers exposed to COPCs in soils and groundwater (by ingestion, inhalation, dermal contact, and external radiation). 
Measurement Endpoint 1: Concentration of COPCs in soil and groundwater.

Decision Rule 1: If hypothetical future industrial workers' contact with COPCs in soils and groundwater results in cancer risks less than $10^{-4}$ for carcinogenic chemicals or a hazard index less than 1 for systemic toxicants, then Remediation Objective 1 has been met and hypothetical future industrial workers are not at risk.

Human Health Remediation Objective 2: No unacceptable adverse effects on current on-unit workers exposed to COPCs in soils (by ingestion, inhalation, dermal contact, and external radiation).

Measurement Endpoint 2: Concentration of COPCs in soil.

Decision Rule 2: If the current on-unit workers' contact with COPCs in soils and estimated concentrations in air results in cancer risks less than $10^{-6}$ for carcinogenic chemicals or a hazard index less than 1 for systemic toxicants, then Remediation Objective 2 has been met and on-unit workers are not at risk.

Human Health Remediation Objective 3: No unacceptable adverse effects on hypothetical future on-unit residents exposed to COPCs in soils, garden produce, air, and groundwater (by ingestion, inhalation, dermal contact, and external radiation).

Measurement Endpoint 3: Concentration of COPCs in soil and groundwater.

Decision Rule 3: If the hypothetical future on-unit residents' contact with COPCs in soils, produce, and groundwater results in cancer risks less than $10^{-6}$ for carcinogenic chemicals or a hazard index less than 1 for systemic toxicants, then Remediation Objective 3 has been met and future hypothetical on-unit residents are not at risk.

\subsubsection{Ecological Assessment Endpoints}

One goal of remediation at the MSSB is to protect current and future ecological receptors and their habitats. Five categories of ecological receptors (threatened and endangered [T\&E] species and four populations or communities) have tentatively been defined:

- T\&E species of plants and animals,

- Terrestrial plant community,

- Soil-dwelling invertebrates, such as earthworms,

- Terrestrial mid-level predators, such as songbirds and insectivores, and

- Top predators of terrestrial, such as hawks. 
Further refinement of potential receptors and routes of exposure will be accomplished following the exposure assessment step of the baseline ecological risk assessment. The potential routes of exposure to terrestrial ecological receptors are defined in the CSM (Figure 3-2).

Ecological risks should be expressed in terms of a definite endpoint. An endpoint is an environmental value to be protected. EPA recognizes two types of endpoints. Assessment endpoints are "explicit expressions of the actual environmental value that is to be protected" (EPA, 1992). Measurement endpoints "are measurable responses to a stressor that are related to the valued characteristics chosen as the assessment endpoint" (EPA, 1992). The ecological assessment endpoints, measurement endpoints, and decision rules for the potential receptors identified for the MSSB are discussed below.

Ecological Assessment Endpoint 1: No reduction in numbers of state- or federallydesignated T\&E species, if present.

Measurement Endpoint 1: T\&E species survey of plants and animals, and COPC concentrations in soil.

Decision Rule 1: If the ratios of COPC concentrations in surface soil or in the future subsurface soil scenario do not exceed toxicity benchmarks that are protective of individuals (e.g. ecological quotient [EQ] less than 1), then Assessment Endpoint 1 has been met and T\&E species are not at risk.

Ecological Assessment Endpoint 2: No substantial adverse effect on terrestrial plant community from exposure to COPCs in surface soil (by dermal contact, i.e., root uptake).

Measurement Endpoint 2: Concentrations of COPCs in surface and subsurface soil.

Decision Rule 2: If the ratio of estimated exposure concentration of any COPC to the phytotoxicity benchmark for adverse effect on vegetation is less than 1, then Assessment Endpoint 2 has been met and the terrestrial plant community is not at risk.

Ecological Assessment Endpoint 3: No substantial adverse effect on populations of soil-dwelling animals from exposure to COPCs in surface soil (by ingestion and dermal contact).

Measurement Endpoint 3: Concentrations of COPCs in surface and subsurface soil.

Decision Rule 3: If the ratio of estimated exposure concentration of any COPC to the toxicity benchmark for adverse effect on soil-dwelling invertebrates is less than 1, then Assessment Endpoint 3 has been met and soil-dwelling invertebrates are not at risk. 
Ecologicai Assessment Endpoint 4: No substantial adverse effect on populations of terrestrial mid-level predators from exposure to COPCs in surface and subsurface soil (by ingestion of surface soil and soil-dwelling invertebrates, by dermal contact with surface and subsurface soil, and by inhalation of volatiles and dust).

Measurement Endpoint 4: Concentrations of COPCs in surface and subsurface soil.

Decision Rule 4: If the ratio of the estimated exposure concentration of any COPC to the toxicity benchmark for adverse effect on terrestrial mid-level predators is less than 1, then Assessment Endpoint 4 has been met and terrestrial mid-level predators are not at risk.

Assessment Endpoint 5: No substantial adverse effect on populations of top predators from exposure to COPCs in surface and subsurface soil.

Measurement Endpoint 5: Concentrations of COPCs in surface and subsurface soil.

Decision Rule 5: If the ratio of the modeled exposure concentration of any COPC in prey to the toxicity benchmark for adverse effect on top predators is less than 1 , then Assessment Endpoint 5 has been met and top predators are not at risk.

\subsection{SURVEY OF HISTORICAL DATA}

Historical Data for the MSSB was summarized from the following sources:

- A-Area and M-Area regional groundwater quality reports,

- Groundwater sampling from nearby monitoring wells,

- Unit Screening (WSRC, 1990), and

- Soil Gas Investigation (Pirkle and Masdea, 1993).

Information from each of the sources of data is described in detail below.

\subsubsection{A- and M-Area Regional Groundwater Quality}

The A- and M-Area soil and groundwater contamination is a result of waste disposal practices previously considered state-of-the-art. The primary source of contamination was the M-Area Settling Basin. The Settling Basin was constructed in 1958 to settle out and contain uranium and other heavy metals discharged from aluminum forming/metal finishing operations. Overflow from the Basin was transported to a natural seepage area to a shallow depression (known locally as Lost Lake) via a drainage ditch. These structures comprise the M-Area HWMF. The facility was removed from service in July 1985 and did not accept wastewater discharges after that date. The effluent discharged to the unlined M-Area Settling Basin contained heavy metals and chlorinated solvents [tetrachloroethylene (PCE), trichloroethylene (TCE), and 1,1,1-trichloroethane (TCA), used as degreasers]. After the discovery of chlorinated solvent groundwater contamination below the Settling Basin in

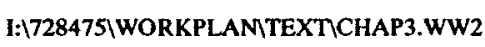


June 1981, SRS established a corrective action program that includes extensive groundwater monitoring and groundwater recovery for treatment. A groundwater recovery well (RMW6) is located southwest of the MSSB, near NPDES outfall A-014 (Figure 3-6). The MSSB is in the zone of capture from RMW6 and A-014.

Installation of assessment monitoring wells in $\mathrm{A} / \mathrm{M}$ Area has been conducted in several stages. Piezometers have been used extensively as part of the groundwater investigation program. They have also been used to aid in the location of the monitoring wells. Monitoring wells, in addition to soil borings, cone penetrometers and piezometers, have all been used in the groundwater monitoring process. This has been a progressive, on-going, phased process with its major emphasis being the delineation of the lateral and vertical extent of groundwater contamination.

The upper and lower "Lost Lake" aquifer zones have the greatest aerial extent of TCE contamination. The highest concentrations are localized around the M-Area Basin, the A014 outfall, the process sewer line and the solvent storage and handling areas. The "MArea" aquifer zone which is most likely to be affected by the MSSB exhibits the next largest aerial extent of TCE contamination (Figure 3-4). The highest concentration of TCE $(3,000,000 \mathrm{ppb}, \mathrm{MSB}-3 \mathrm{D})$ was noted in the "M-Area" aquifer zone. This well, located at the junction of the M-Area Settling Basin and the process sewer line, is also the site of the only confirmed dense nonaqueous phase liquid (DNAPL) occurrence. The trend in the "middle sand" of the Crouch Branch confining unit and the Crouch Branch aquifer is toward a smaller aerial extent and lower concentrations of contaminants. Well AOB1, located near the MSSB and screened in the "M-Area" aquifer zone, was found to contain 44 ppb of TCE.

As with TCE, PCE has its greatest aerial extent of contamination in the upper "Lost Lake" aquifer zone. The "M-Area" aquifer zone has an almost equal aerial extent (Figure 35). The highest concentrations are noted around the M-Area Basin, the A-014 outfall, the process sewer line and the storage and handling areas. As with TCE, MSB-3D noted the highest concentration of PCE $(33,000,000 \mathrm{ppb})$. The deeper aquifers/aquifer zones (the "middle sand" of the Crouch Branch confining unit and the Crouch Branch aquifer) exhibit the least extent of contamination. The general trend is for the contaminants to migrate with the predominant groundwater flow direction (south and southwest) and for them to move deeper in the section. Well AOB1 was found to contain $47 \mathrm{ppb}$ of PCE.

It is evident from both the TCE and PCE isoconcentration maps (Figures 3-4 and 3-5) that the MSSB is not contributing to the observed groundwater contamination, but that the contamination has its source elsewhere. 


\subsubsection{Monitoring Well Data}

Figure 3-6 shows the locations of existing groundwater wells near the MSSB. Three wells are located in the immediate vicinity of the unit: AOB1, AOB2, AOB3 and one well cluster MSB35, which consists of three wells, MSB35A, MSB35B and MSB35TA. Groundwater wells in the A-Area are sampled and analyzed for a wide range of parameters. The parameters analyzed include indicators of water quality $(\mathrm{pH}$, specific conductivity, gross alpha, nonvolatile beta, etc.) and specific chemical constituents including organic compounds, specific radionuclides, and nonradiological inorganic species. Not all parameters were analyzed for in all quarters. Contamination in the groundwater can be divided into two categories, organic and inorganic. A list of constituents detected above the Primary Drinking Water Standards (PDWS) in groundwater (EPA, 1995) is presented in Table 3.2.

Two organic constituents, dichloromethane, and trichloroethylene, have been detected above PDWS at least once during the time period from the first quarter of 1991 to the last quarter of 1995. Both are chlorinated volatile organic compounds that have been known to be used at the SRS. Two inorganic constituents have been detected above PDWS at least once during the same time period. They are antimony and mercury.

Dichloromethane and trichloroethylene were both detected at maximum levels in Well $A O B 1$, which is screened in the "M-Area" aquifer zone. Antimony was detected at maximum levels in Well AOB2, which is also screened in the "M-Area" aquifer zone. Mercury was detected at maximum levels in Well MSB35A, which is screened in the "Middle Sand" aquifer zone of the Crouch Branch confining unit.

\subsubsection{Unit Screening}

According to the RFI/RI Program Plan, Unit Screening activities must include one or more of the following:

- Geophysical investigations,

- Soil gas analysis, and/or

- Confirmation soils analysis.

The initial unit screening, performed at the MSSB in November 1988 (WSRC, 1990), consisted of confirmation soils analysis. A geophysical investigation was not conducted because of the historical use of the seepage basin. There was no evidence to suggest that buried objects would be found there. A soil gas analysis was not initially planned, but was performed in 1991 as described below. The confirmation soils analysis consisted of a screening for non-volatile organic compounds, inorganic species, and radioactivity and a verification of the presence or absence of volatile organic compounds. Since no historic evidence of overflow of the basin was found, all sampling activities were conducted within the physical boundaries of the basin. The sampling locations are shown in Figure 3-7.

I:|728475|WORKPLANTEXICHAP3.WW2 
The soil samples were analyzed at the intervals and for the constituents indicated in Table 3.3. Overall, the QC sample results indicate that the field sampling and laboratory handling met the quality assurance objectives (WSRC, 1990). Two constituents were detected in the laboratory method blanks, acetone and methylene chloride. Both are documented laboratory artifacts and the identification of those compounds in unit soils may indicate laboratory contamination.

Table 3.4 presents the results of the soil analyses. The concentrations listed are reported as "above detection limits," however, the detection limits were not reported. Since background soil compositions have not been determined, the reported values cannot be considered "remediation trigger levels" or "clean-up levels." Volatile organic compounds, specifically acetone and methylene chloride, and metals were the primary hazardous constituents detected in soil samples collected from the basin. As stated above, both acetone and methylene chloride were detected in the laboratory method blank, therefore, their actual presence in unit soils is suspect. Metals detected in the soils include: antimony, arsenic, barium, cadmium, chromium, copper, lead, mercury, nickel, thallium, vanadium, and zinc. The following semi-volatile organic constituents were also detected: 2-methylnaphthalene, bis-(2-ethylhexyl)phthalate, ethylbenzene, fluoranthene, phenanthrene, pyrene, and xylenes. One sample was found to contain PCB 1254. Four samples from two boreholes were analyzed for radioactivity. One sample, from Boring 4 at 25 to $27^{\prime}$ bls had a gross beta concentration above the detection limit. None had gross alpha or radium above detection limits.

\subsubsection{Soil Gas Investigation}

A soil gas survey was performed for the MSSB in 1991 (Pirkle and Masdea, 1993). In total, 188 locations in and near the Seepage Basin were sampled. The objective of the survey was to determine the nature and extent of contamination in near surface soil gases at the site. The following compounds were monitored: $\mathrm{C}_{1}-\mathrm{C}_{4}$ hydrocarbons; $\mathrm{C}_{5}-\mathrm{C}_{10}$ normal paraffins; the aromatic hydrocarbons, benzene, toluene, ethylbenzene and xylenes (BTEX); selected chlorinated hydrocarbons; and mercury. The analytical results for the soil gas survey are summarized in Table 3.5 .

Mercury was detected only in minor amounts within the MSSB and only low levels of VOCs were found. Only pentane and tetrachloroethylene had occurrence frequencies greater than ten percent. The analytical results for the light hydrocarbons indicate that all analytes except the butanes, had occurrence frequencies greater than fifty percent. A large chlorinated hydrocarbon plume was detected to the west of the basin. The most significant contaminant in the plume was found to be tetrachloroethylene. Other compounds found include: trichloroethylene, chloroform, carbon tetrachloride, 1,1,1-trichloroethane, and trans1,2-dichloroethylene. The areal extent of contamination was not determined in this study. 


\subsubsection{Adequacy of Historical Data and New Data Needs}

Based on the unit screening data, hazardous materials have been managed at the MSSB and additional investigations are required, in accordance with the RFI/RI Program Plan. Sufficient historical data are not available to determine the nature and extent of contamination in the MSSB. Additional data are needed to determine the vertical and horizontal extent of contamination and for input to conduct the BRA. 
RFI/RI Work Plan for the Motor Shops Seepage Basin
WSRC-RP-96-00111, Revision 0

March 1996

THIS PAGE LEFT BLANK INTENTIONALLY. 
Table 3.1. Summary of Data Quality Objectives for 716-A Motor Shops Seepage Basin

\begin{tabular}{|c|c|c|}
\hline Activity & Groundwater Samples & $\begin{array}{l}\text { Surface \& Subsurface } \\
\text { Soil Samples }\end{array}$ \\
\hline Analytical Test & $\begin{array}{l}\text { TCL (VOCs, SVOCs, } \\
\text { Pesticides/PCBs), \& TAL } \\
\text { (metals) }\end{array}$ & $\begin{array}{l}\text { TCL (VOCs, SVOCs, } \\
\text { Pesticides/PCBs), TAL (metals), } \\
\text { pH \& TOC }\end{array}$ \\
\hline Level of Concern & Detection Limit & Detection Limit \\
\hline Required Detection Limit & PQL & PQL \\
\hline Staff Requirements & Technican & $\begin{array}{l}\text { Geologist, Technician, } \\
\text { Driller, Technical Oversight }\end{array}$ \\
\hline Number of Samples & TBD & TBD \\
\hline QA/QC Samples & TBD & TBD \\
\hline Sampling Procedure & Pump & Direct Fill \& Split Spoon \\
\hline \multicolumn{3}{|l|}{$\begin{array}{l}\text { Analytical Methods/ } \\
\text { Equipment }\end{array}$} \\
\hline \multirow[t]{2}{*}{ Screening } & Scanner & OVA, HNu \& Scanner \\
\hline & $\begin{array}{l}\mathrm{pH} / \text { conductivity meter \& } \\
\text { thermometer }\end{array}$ & $\begin{array}{l}\text { PAH\& PCB immunoassay } \\
\text { test kits }\end{array}$ \\
\hline Definitive & $\begin{array}{l}\text { SW846, } \\
\text { 40 CFR } 136\end{array}$ & $\begin{array}{l}\text { SW846, } \\
40 \text { CFR } 136\end{array}$ \\
\hline
\end{tabular}

TCL Target Compound List

TAL Target Analyte List

PQL Practical Quantitation Limit

TBD To be determined

SW846 Test Method for Evaluating Solid Waste, 34d Edition, EPA, 1986.

40 CFR 136 Appendix A, Office of the Federal Register, National Archives and Records Administration, July 1988.

AVS Acid Volatile Sulfides by Draft Analyte Method for Determination of ASS in Sediment, December 1991, EPA; 
Table 3.2. List of Constituents Detected

Above the Primary Drinking Water Standards in Groundwater During at Least

One Quarter Between the First Quarter of 1991 to the Fourth Quarter of 1995

Motor Shops Seepage Basin

\begin{tabular}{|c|c|c|c|c|}
\hline Constituent & $\begin{array}{c}\text { Maximum } \\
\text { Contaminant } \\
\text { Level }^{(1)}(\mathrm{mg} / \mathrm{L})\end{array}$ & $\begin{array}{l}\text { Amount } \\
\text { Detected } \\
(\mathrm{mg} / \mathrm{L})\end{array}$ & Well & Aquifer \\
\hline \multicolumn{5}{|l|}{ Organic } \\
\hline Dichloromethane & .005 & .0358 & AOB1 & "M-Area" Aquifer Zone \\
\hline Trichloroethylene & .005 & .0641 & AOB 1 & "M-Area" Aquifer Zone \\
\hline \multicolumn{5}{|l|}{ Inorganic } \\
\hline Antimony & .006 & .0085 & AOB2 & "M-Area" Aquifer Zone \\
\hline Mercury & .002 & .0039 & MSB35A & $\begin{array}{l}\text { "Middle Sand" Aquifer } \\
\text { Zone of the Crouch } \\
\text { Branch Confining Unit }\end{array}$ \\
\hline
\end{tabular}

(1) SOURCE: EPA DRINKING WATER REGULATIONS AND HEALTH ADVISORIES, MAY 1995

WELLS INCLUDED: AOB1, AOB2, AOB3, AND MSB35 
Table 3.3. Sampling Intervals and Constituents Analyzed 716-A Motor Shops Seepage Basin

\begin{tabular}{|c|c|c|c|c|c|}
\hline $\begin{array}{l}\text { Facility } \\
\text { Number }\end{array}$ & $\begin{array}{l}\text { Sampling } \\
\text { Borehole } \\
\text { Number }\end{array}$ & $\begin{array}{l}\text { Sample } \\
\text { Number }\end{array}$ & $\begin{array}{l}\text { Sampling* } \\
\text { Depth }\end{array}$ & $\begin{array}{l}\text { Constituents } \\
\text { Analyzed } * * *\end{array}$ & $\begin{array}{c}\mathrm{QC} \\
\text { Samples }\end{array}$ \\
\hline A716B & 01 & 01 & $0.2-0.5$ feet & 1 & \\
\hline A716B & 01 & 02 & $26-27$ feet & 2,3 & \\
\hline A716B & 01 & 03 & $30.5-32.5$ feet & 2,3 & \\
\hline A716B & 02 & 01 & $2-4$ feet & $2,3,4$ & \\
\hline A716B & 02 & 02 & $2-4$ feet & $2,3,4$ & QC duplicate \\
\hline A716B & 02 & 03 & $20-21$ feet & 2 & \\
\hline A716B & 03 & 01 & $2-4$ feet & 2,3 & \\
\hline A716B & 03 & 02 & $20-22$ feet & 2 & $\mathrm{QC}^{* *}$ split \\
\hline $\mathrm{A} 716 \mathrm{~B}$ & 03 & 03 & - & 2 & QC rinsate \\
\hline A716B & 04 & 01 & $2-4$ feet & 2,3 & \\
\hline A716B & 04 & 02 & $25-27$ feet & 2,4 & \\
\hline A716B & 04 & 03 & -- & 2 & QC rinsate \\
\hline $\mathrm{A} 716 \mathrm{~B}$ & 04 & 04 & $30-32$ feet & 2,4 & \\
\hline A716B & 05 & 01 & $0.1-0.7$ feet & 1 & \\
\hline $\mathrm{A} 716 \mathrm{~B}$ & 05 & 02 & -- & 2 & QC rinsate \\
\hline A716B & 05 & 03 & -- & 5 & $\begin{array}{l}\text { QC Field } \\
\text { Blank }\end{array}$ \\
\hline A716B & 05 & 04 & -- & 2 & QC rinsate \\
\hline
\end{tabular}

From: WSRC, 1990. RCRA Facility Investigation/Remedial Investigation Plan for the 716-A Motor Shop Seepage Basin, WSRC-RP-90-581

*** Constituent analytical codes are as follows:

1) EPA Appendix VIII

2) Volatile organics, semi-volatile organics

3) EP toxicity metals

4) Radionuclide indicators (gross alpha, gross heta, total radium, tritium)

5) Volatile organics

* Intervals referenced as depth beneath the basin bottom.

** Analyzed by the QC Laboratory 
Table 3.4. Chemical Analysis Results for Soils 716-A Motor Shops Seepage Basin

\begin{tabular}{|c|c|c|c|c|c|c|c|c|c|c|c|}
\hline Sample ID & $1-1^{*}$ & $1-2$ & $2-1$ & 2-2D & $2-3$ & $3-1$ & $3-2$ & $3-3 \mathrm{~S}$ & $4-1$ & $4-2$ & $5-1^{*}$ \\
\hline Depth (feet) & $0.2-0.5$ & $26-27$ & $2-4$ & $2-4$ & $20-21$ & $2-4$ & $20-22$ & $20-22$ & $2-4$ & $25-27$ & $0.1-0.7$ \\
\hline \multicolumn{12}{|c|}{ Organic Constituents $\mu \mathrm{g} / \mathrm{kg}$} \\
\hline Acetone & 54 & 54 & 53 & 160 & 43 & 57 & 30 & 100 & 45 & ND & ND \\
\hline Bis(2-Ethylhexyl)Phthalate & 520 & ND & ND & ND & ND & $\mathrm{ND}$ & ND & ND & ND & ND & 6600 \\
\hline Ethylbenzene & ND & ND & ND & ND & ND & ND & ND & ND & 7.0 & ND & ND \\
\hline Fluoranthene & 40 & ND & ND & ND & ND & $\mathrm{ND}$ & ND & ND & ND & ND & ND \\
\hline Methylene chloride & 11 & 11 & 10 & 13 & 3 & 7 & 9 & 14 & 20 & 8 & 12 \\
\hline 2-Methylnaphthalene & ND & ND & ND & ND & ND & ND & ND & ND & 320 & ND & ND \\
\hline PCB 1254 & ND & NA & NA & NA & NA & $\mathrm{NA}$ & NA & NA & NA & NA & 1400 \\
\hline Phenanthrene & ND & ND & ND & ND & ND & ND & ND & ND & ND & ND & 250 \\
\hline Pyrene & 60 & ND & ND & ND & ND & ND & ND & ND & ND & ND & 620 \\
\hline Xylenes & ND & ND & ND & ND & ND & ND & ND & ND & 15 & ND & ND \\
\hline \multicolumn{12}{|l|}{ Metals mg/kg } \\
\hline Antimony & ND & NA & NA & NA & NA & NA & NA & NA & NA & NA & 10 \\
\hline Arsenic & 1.1 & NA & NA & NA & NA & NA & NA & NA & NA & NA & 3.6 \\
\hline Barium & 15 & NA & NA & NA & NA & NA & NA & NA & NA & NA & 34 \\
\hline Cadmium & ND & NA & NA & NA & NA & NA & NA & NA & NA & NA & 1.7 \\
\hline Chromium & 119 & NA & NA & NA & NA & NA & NA & NA & NA & NA & 68 \\
\hline Copper & 4.3 & NA & NA & NA & NA & NA & NA & NA & NA & NA & 52 \\
\hline Lead & 11 & NA & NA & NA & NA & NA & NA & NA & NA & NA & 73 \\
\hline Mercury & 0.2 & NA & NA & NA & NA & NA & NA & NA & NA & NA & 0.35 \\
\hline Nickel & 55 & NA & NA & NA & NA & NA & NA & NA & NA & NA & 28 \\
\hline Thallium & ND & NA & NA & NA & NA & NA & NA & NA & NA & NA & 1.0 \\
\hline Vanadium & 7.4 & NA & NA & NA & NA & NA & NA & NA & NA & NA & ND \\
\hline Zinc & 21 & NA & NA & NA & NA & NA & NA & NA & NA & NA & 51 \\
\hline \multicolumn{12}{|l|}{ Toxicity Results $\mu \mathrm{g} / \mathbf{I}$} \\
\hline Barium & NA & 29 & 152 & 115 & NA & 70 & NA & NA & 8.9 & NA & NA \\
\hline Chromium & NA & ND & 19 & ND & NA & ND & NA & NA & ND & NA & NA \\
\hline Mercury & NA & 0.33 & 0.46 & 0.44 & NA & 0.43 & NA & NA & 0.37 & NA & NA \\
\hline $\begin{array}{l}\text { Radionuclides } \mathrm{pCi} / \mathbf{g} \\
\text { Common Ions } \mathrm{mg} / \mathbf{k g}\end{array}$ & NA & NA & ND & ND & NA & NA & NA & NA & NA & 9.5 & NA \\
\hline Chloride & 1.9 & NA & NA & NA & NA & NA & NA & NA & NA & NA & ND \\
\hline Nitrate as Nitrogen & 1.8 & NA & NA & NA & NA & NA & NA & NA & NA & NA & 1.2 \\
\hline Sulfate & 12 & NA & NA & NA & NA & NA & NA & NA & NA & NA & 7.5 \\
\hline
\end{tabular}

Notes: NA - Not-Analyzed

ND - Non-Detect

An "S" extension to the interval number indicates a split sample.

A " $D$ " extension to the interval number indicates a duplicate sample.

*Appendix VIII analysis.

Source: WSRC, 1990

Only samples with compounds detected above detection limits are reported. 
Table 3.5. Soil Gas Survey Results

Motor Shops Seepage Basin (716-A)

\begin{tabular}{llc}
$\begin{array}{llc}\text { Chlorinated Hydrocarbons and Carbon- } \\
\text { chain Compounds }\left(\mathrm{C}_{5} \text { to } \mathrm{C}_{10}\right)(\mathrm{ppm})\end{array}$ & \multicolumn{1}{c}{ Range } & $\begin{array}{c}\text { Frequency } \\
\text { of } \\
\text { Detection }\end{array}$ \\
\hline Pentane & ND - 1.19 & $5 / 55$ \\
Hexane & ND & $0 / 55$ \\
Heptane & ND - 0.64 & $1 / 55$ \\
Benzene & ND & $0 / 55$ \\
Octane & ND & $0 / 55$ \\
Toluene & ND & $0 / 55$ \\
Nonane & ND & $0 / 55$ \\
Ethylbenzene & ND & $0 / 55$ \\
m and p-Xylenes & ND & $0 / 55$ \\
o-Xylene & ND - 1.48 & $3 / 55$ \\
Decane & ND & $0 / 55$ \\
Vinyl Chloride & ND & $0 / 55$ \\
Methylene chloride & ND & $0 / 55$ \\
trans-1,2-Dichloroethylene & ND & $0 / 55$ \\
Chloroform & ND & $0 / 55$ \\
1,1,1-Trichloroethane & ND - 0.008 & $1 / 55$ \\
Carbon tetrachloride & ND & $0 / 55$ \\
Trichloroethylene & ND - 0.11 & $2 / 55$ \\
Tetrachloroethylene & ND - 0.123 & $9 / 55$ \\
\hline Light Hydrocarbons $(\mathrm{ppb})$ & & \\
\hline Methane & $103-291$ & $55 / 55$ \\
Ethane & $9-495$ & $55 / 55$ \\
Propane & ND - -160 & $48 / 55$ \\
n-Butane & ND - 13 & $50 / 55$ \\
\hline Propylene & ND - 116 & $18 / 55$ \\
\hline
\end{tabular}

From: Pirkle and Masdea (1993)

ND - Not Detected

C - Carbon

ppm - parts per million

ppb - parts per billion 


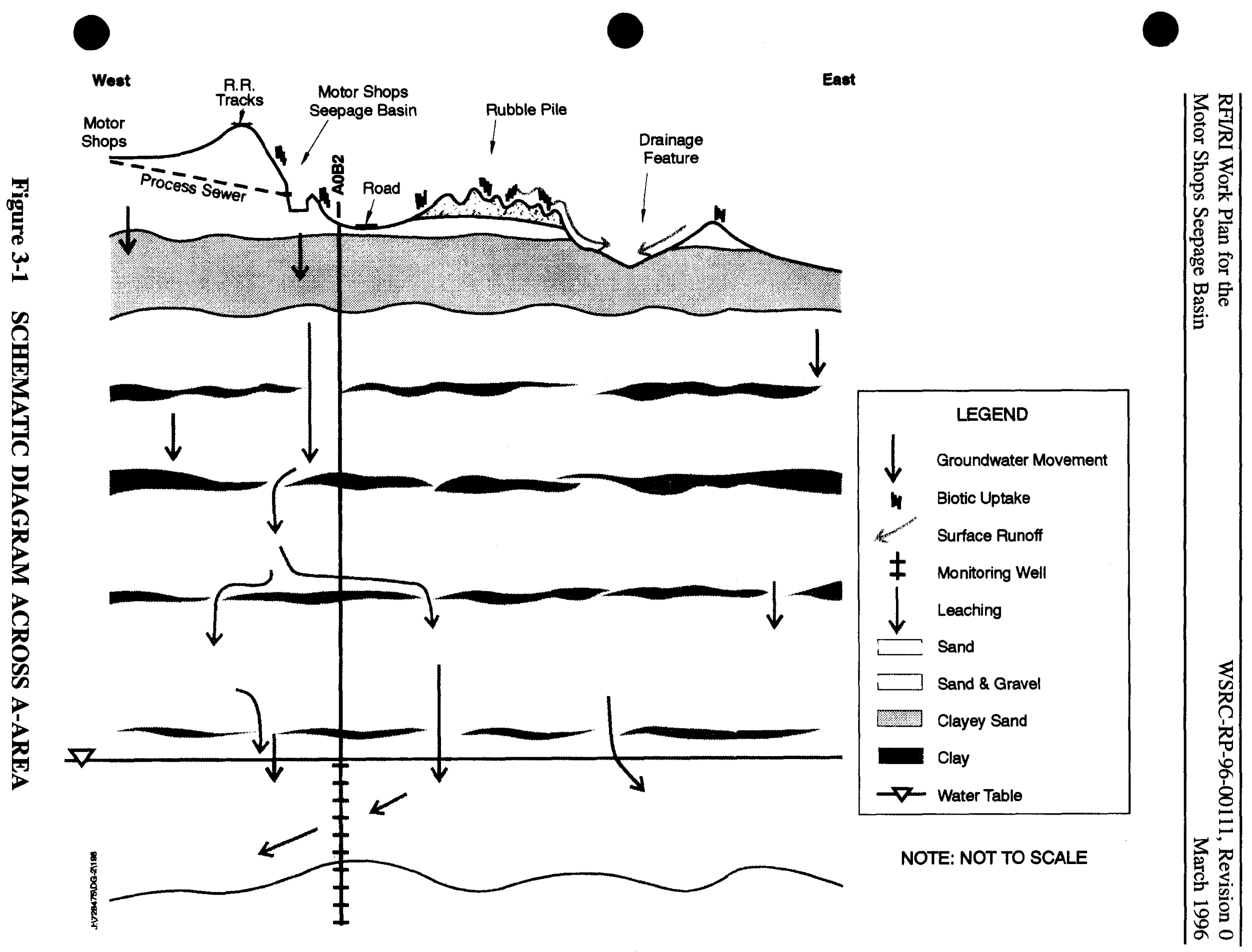




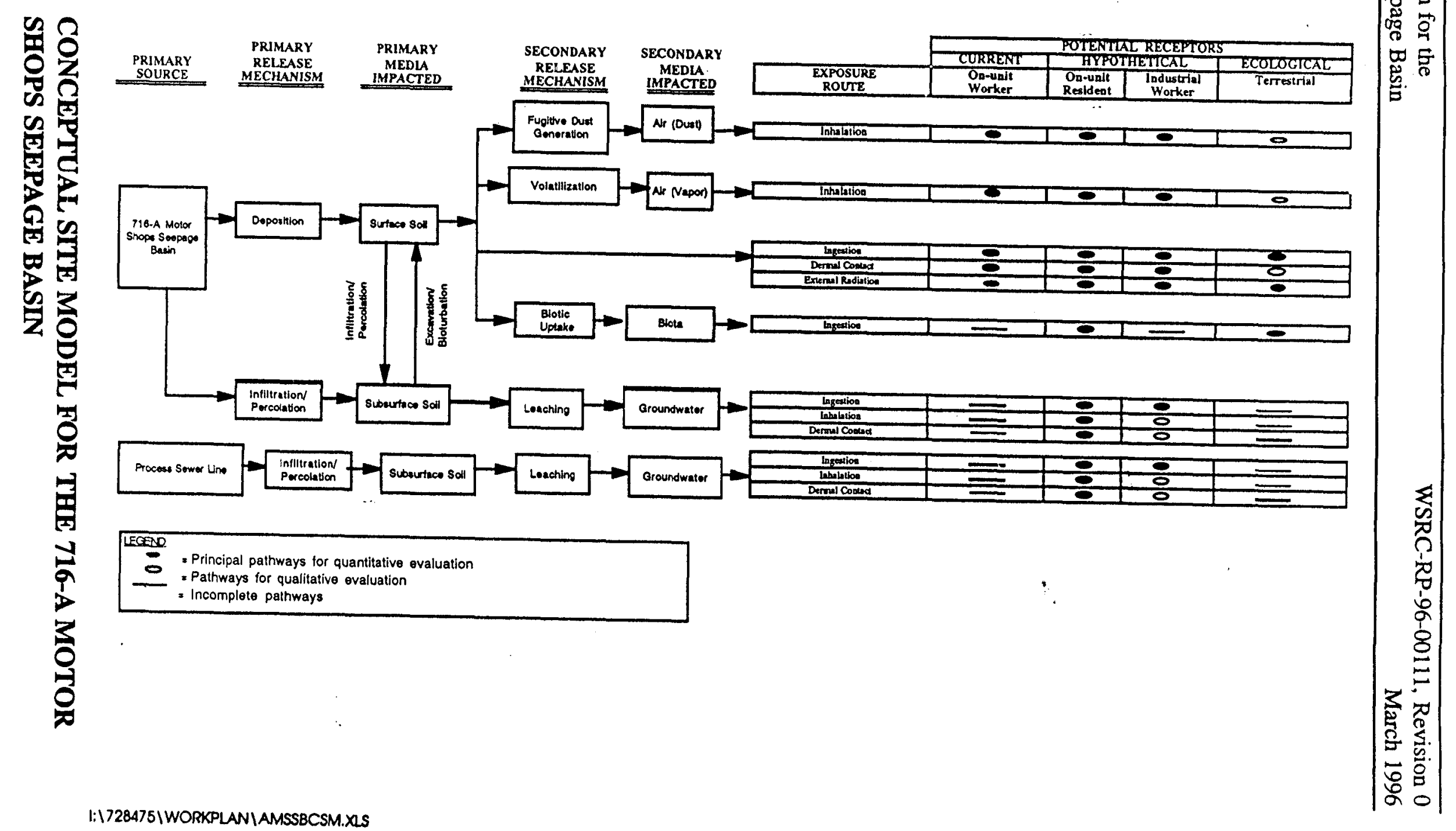


$\stackrel{\omega}{\omega}$

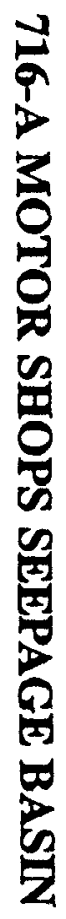
政
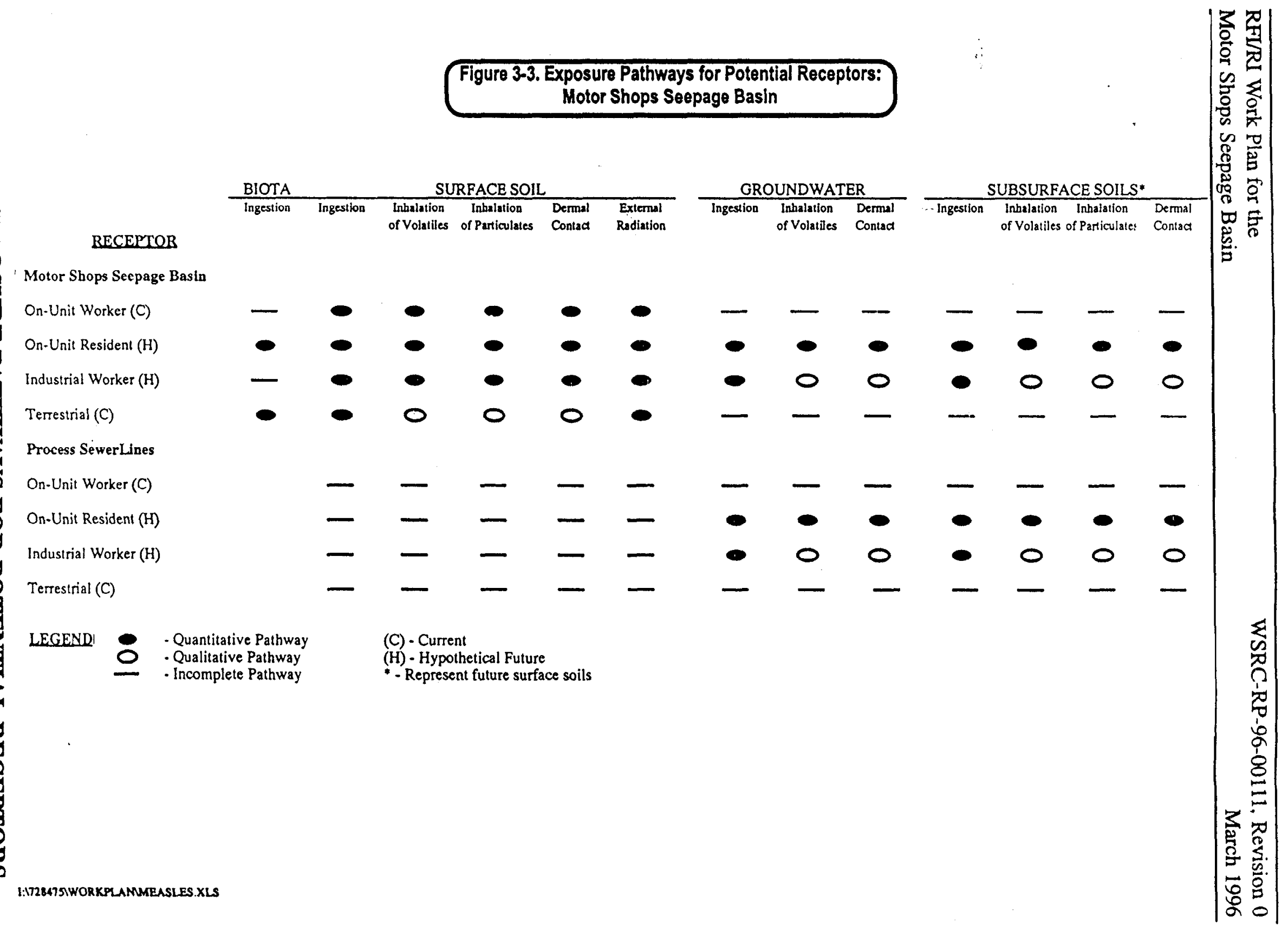

RECERTOB

Motor Shops Secpage Basin

On-Unit Worker (C)

On-Unit Resident (H)

Industrial Worker $(\mathrm{H})$

Terrestrial (C)

Process SewerLines

On-Unit Worker (C)

On-Unit Resident (H)

Industrial Worker $(\mathrm{H})$

Terrestrial (C)

LEGEND|

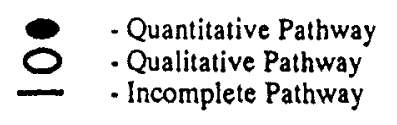

(H) - Hypothetical Future

- Represent future surface soils

$E$

20

2

扈

I:T2BA7SIWORKPLAMMEASLES.XLS 


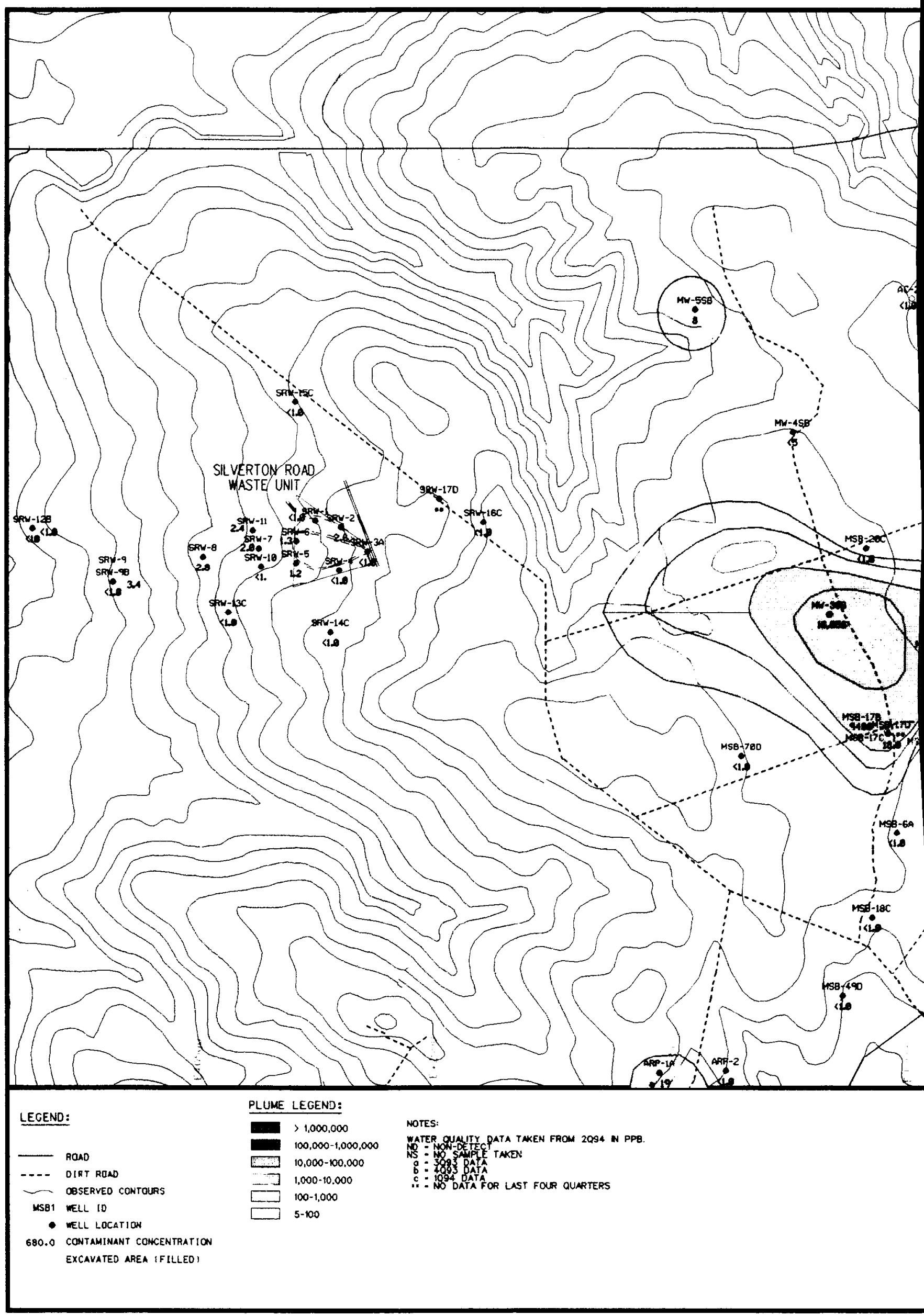




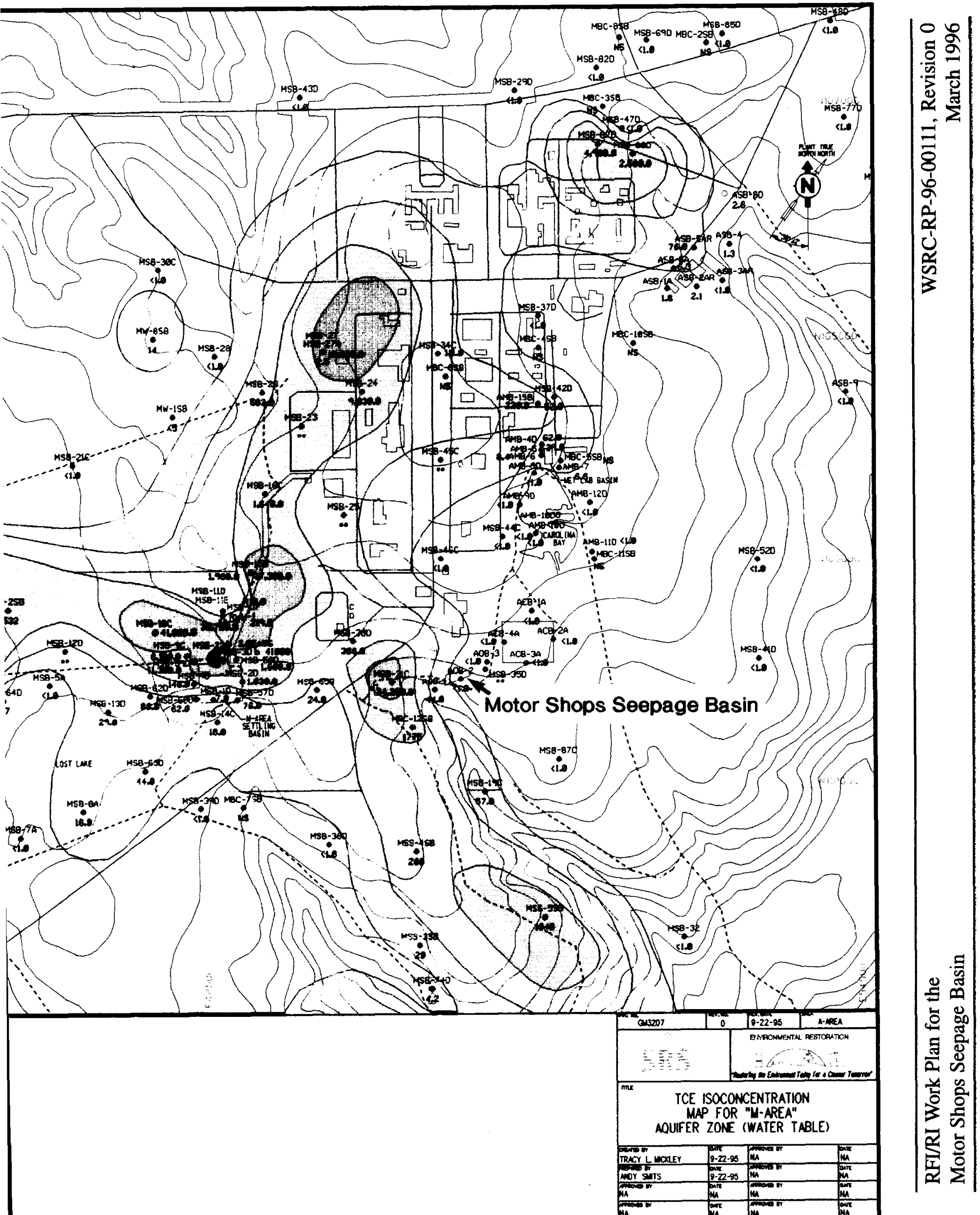




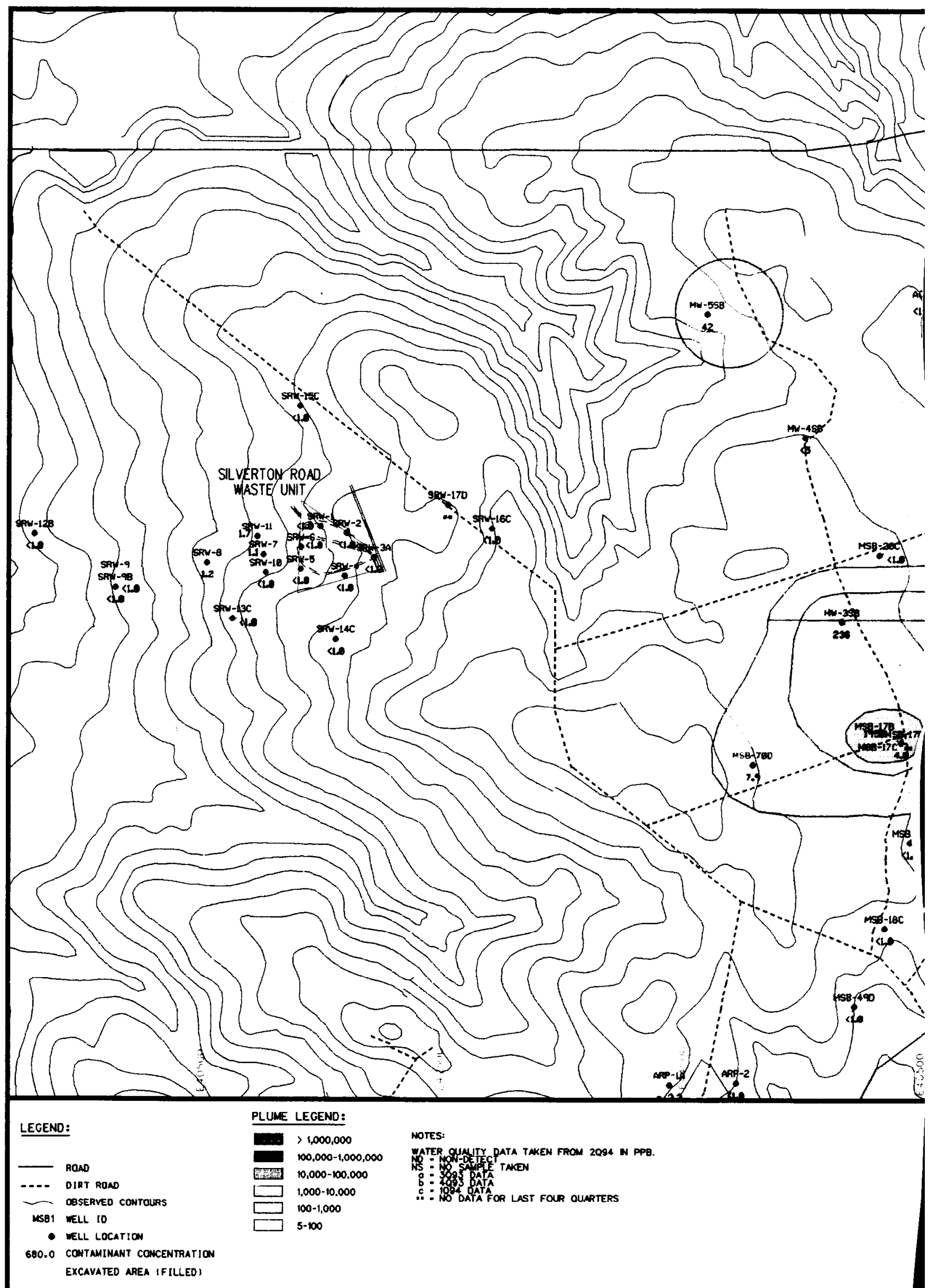




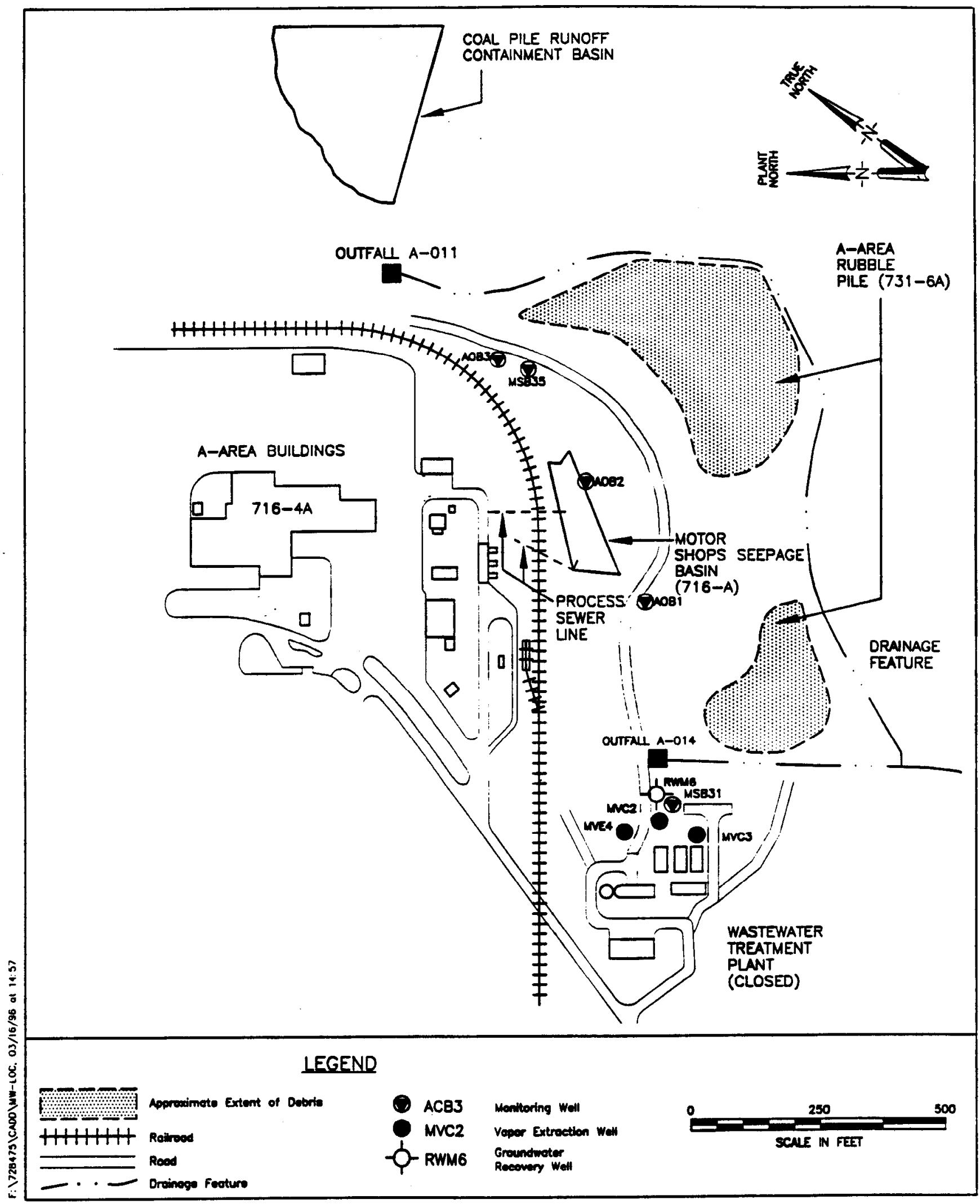

Figure 3-6 MOTOR SHOPS SEEPAGE BASIN MONITORING WELL LOCATIONS 


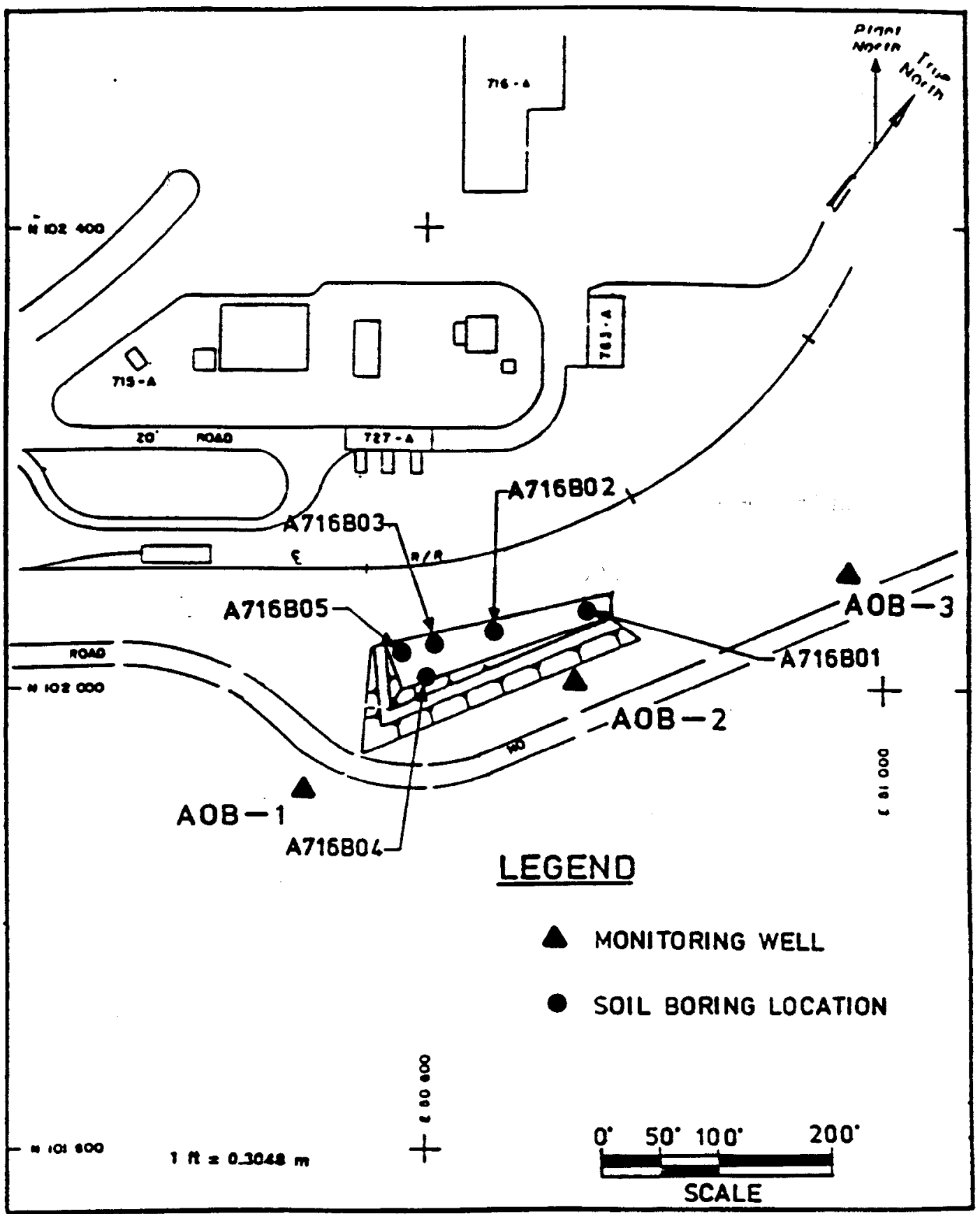

Source: Modified from DPST-85-701, E.I. duPont de Nemours and Co., March, 1987 


\section{CHAPTER 4 UNIT ASSESSMENT}

\subsection{CHARACTERIZATION PLAN SUMMARY}

The goal of the Unit Assessment for the 716-A Motor Shops Seepage Basin (MSSB) is to evaluate if hazardous or radioactive substances are present in the Seepage Basin and, if so, whether releases have occurred to surrounding soils or groundwater. Based on known disposal practices at the unit and the results of previous sampling efforts within the basin perimeter, there is the potential that one or more media associated with the basin may require remediation.

The RFI/RI characterization will consist of a phased approach to streamline characterization efforts, eliminate unnecessary sampling, and provide sufficient data required to help make decisions at various points in the environmental assessment process. The media targeted for sampling and analysis are groundwater, surface soils $\left(0-1^{\prime}\right)$, subsurface soils $\left(1^{\prime}-4^{\prime}\right)$ and deep subsurface soils ( $>4 \mathrm{ft}$ below land surface).

The assessment of the environmental media will be accomplished using the principles of the Expedited Site Characterization (ESC) methodology. ESC incorporates on-site decision-making technologies that permit site characterizations to be completed in a streamlined manner, without compromising data quality. The field work will be divided into two phases: 1) primary source characterization and definition of unit specific contaminants (USCs); and 2) determination of extent of the USCs (if present).

The first phase field effort will be called the ESC Phase 1 and will include sampling of surface and subsurface soils for the determination of USCs and unit-specific background concentrations. Screening levels will be based upon two times the mean background concentration levels, EPA Region III RBCs (for carcinogenic risk levels of $1 \times 10^{-6}$ and non-carcinogenic hazard quotients of 0.1 ) and nutrient screening. An evaluation of potential for USC soil leachability to groundwater will be conducted. Unit specific contaminants are those exceeding the screening criteria established for Phase 1. ESC Phase 2, if required, will incorporate results of Phase 1 and all other previous information to determine the extent of USC contamination (if present) in the various media of concern. Information obtained during ESC Phase 2 will assist the SRS management in the evaluation of remedial action alternatives as warranted.

All Phase 1 chemical analysis will be performed by fixed offsite laboratories and SW846 methods. 
For Phase 2, chemical analysis will be accomplished by an offsite laboratory, field analytic instruments that strictly adhere to USEPA SW-846 methods normally associated with off-site laboratories or a combination of both. This will be done for all USCs. In particular, the definitive type of data (EPA, 1994) can be attained in the field by strict adherence to all SW-846 method requirements for all contaminants indicated for the MSSB unit. In addition, the field analytical systems will have the capability to switch to screeningwith-confirmation data quality when tracking samples targeted for USCs, thus allowing the lab to maximize the cost effectiveness of analytical resources while maintaining flexibility to preserve on-site decision making. In this latter respect, ESC is similar to the observational method in that ESC also demands the ability to make decisions on-site, based on reliable data taken in the field.

ESC Phase 2 requires the ability to make decisions in the field by experts with experience in using appropriate sampling and investigative techniques. Specifically, the ESC field team personnel will transform field data into information applicable to the conceptual site model in near real-time and will direct subsequent data gathering activities based on this information. Various groups responsible for the key field data sets will convene as necessary to reach consensus on the implications of data collected to date and on remaining data gaps to be filled. Operational decisions will be made by the ESC Site Manager, in consultation with members of the field team, so that subsequent sampling locations can be assigned based on best available information.

Section 4.2 identifies the decision rules and respective data needs for characterization of the MSSB. Section 4.3 outlines the specific sampling objectives of the Characterization Sampling Plan. Section 4.4 provides a discussion of analytes and unit specific contaminants. The unit-specific characterization sampling/analysis plan is provided in Section 4.5. All sampling activities will follow the guidelines for investigations as detailed in Hydrogeologic Data Collection Procedures and Specifications (WSRC, 1993b).

\subsection{UNIT DECISION RULES AND RESPECTIVE DATA NEEDS}

Probable unit conditions, that have been determined by review of operational and specific-event history, potential primary sources, release mechanisms and exposure pathways, and data collected to date, indicate that contaminants may be present in the surface and subsurface vicinity of the unit. The decision focus presented in Section 3 of this work plan is to acquire data to determine the extent of unacceptable environmental impacts, assess the risk associated with the impacts, and characterize the media for which remediation would be necessary to reduce the risk to an acceptable level. Based on preliminary remedial objectives, identified data needs, and specified temporal/spatial boundaries of the unit, decision rules have been formulated for the MSSB. These decision rules will be used to 
determine the quantity and quality of data required to provide adequate information upon which decisions relative to remediation of the MSSB can be based. Several unit uncertainties or critical data gaps have been identified for each decision rule that represent data needs necessary to make unit decisions.

The screening levels for these decision rules will follow EPA Region IV guidance (EPA, 1995). The screening levels will be based upon two times the mean background concentration levels, EPA Region III RBCs (for carcinogenic risk levels of $1 \times 10^{-6}$ and non-carcinogenic hazard quotients of 0.1 ) and essential nutrient screening. The final determination of whether an analyte is designated as a USC will be made by mutual consensus between SRS, SCDHEC, and EPA representatives.

Phase 1 unit-specific background concentration for soils will be determined by collection of 6 samples each of surface soil and subsurface soil from locations presumed to be unaffected by unit activities and analyzed for the following parameters: target analyte list (TAL), target compound list plus tentatively identified compounds (TCL/TIC), total petroleum hydrocarbons (TPH), gross alpha/non-volatile beta radiological suites, total organic carbon (TOC), and $\mathrm{pH}$. Phase 2 unit-specific background concentration for groundwater will be determined by collection of 4 upgradient groundwater samples. Groundwater samples will be analyzed for USCs as determined by Phase 1 . The unitspecific background is defined as the average of the concentrations measured in these samples for each respective parameter in each respective media.

The following presents five unit-specific Decision Rules along with data needs to support the respective decisions. Decisions Rules 1 and 2 pertain to the investigation of surface soil, subsurface soil and deep subsurface soil. Figure 4-1 provides the decision logic for the unit surface soil subsurface soil and deep subsurface soil investigation as it applies to the support of Decision Rules 1 and 2.

Decision Rule 1 deals with the determination of USCs in the surface soils and subsurface soils.

Decision Rule 1: If the maximum concentration of any constituent analyzed during initial surface soil and subsurface soil sampling within the unit is above the screening level, then designate those chemicals as USCs for surface and subsurface soils.

Data needs to support Decision Rule 1 are as follows:

- locations of probable highest soil concentration based on historical information and previous investigations. 
- $\quad$ surface soil and subsurface soil analytical data from within the unit and unit-specific background.

Since existing data of unit-specific surface soil and subsurface soil conditions are inadequate for decision making, initial assessment activities will focus on determining the USCs. Initial surface soil and subsurface soil sampling will be biased toward detection of the highest concentrations and maximum number of contaminants. Accordingly, the selection of sampling locations will be based on historical use of the MSSB and previous soil sampling results. Analytical results from this initial sampling will be compared to screening levels to develop a preliminary USC list for surface soil and subsurface soil. The USC list will be finalized by consensus with SCDHEC and EPA.

Decision Rule 2 describes activities required in the event that any USCs are found and relates to the identification of the nature and extent of contamination in surface soils, subsurface soils and deep subsurface soils.

Decision Rule 2: $\quad$ If the concentration of USCs are determined to exceed screening levels in surface, subsurface soils or deep subsurface soil samples collected from within or near the unit, then additional samples will be taken within a 10-foot radius of that sample to establish the extent of contamination

Data needs to support Decision Rule 2 as follows:

- analytical results for surface soils, subsurface soils and deep subsurface soils from both ESC sampling phases.

The sampling data needs for Decision Rule 2 will be obtained during both ESC phases, if USCs are found.

Decision Rules 3 and 4 pertain to the investigation of impacts to the environment as a result of the process sewer lines. Figure 4-2 provides the decision logic for the process sewer line investigation as it applies to the support of Decision Rules 3 and 4.

Decision Rule 3 deals with determining whether the process sewer lines have had an impact on surface soils.

Decision Rule 3: $\quad$ If the maximum concentration of any constituent analyzed during initial surface and subsurface soil sampling within the unit is above the screening level, then determine whether the process sewer lines have had an impact on the environment. 
Data needs to support Decision Rule 3 are:

- analytical data from soils adjacent to the process sewer line.

The sampling data needs for Decision Rule 3 will be obtained during the ESC Phase 2, if USCs are found.

Decision Rule 4 describes activities required in the event that any USCs are found in soils adjacent to the process sewer line and relates to the identification of the nature and extent of contamination in surface soils and subsurface soils adjacent to the process sewer line.

Decision Rule 4: $\quad$ If the maximum concentration of any constituent analyzed during soil sampling adjacent to the process sewer line is above the screening level, then determine the lateral and vertical extent of the contamination.

Data needs to support Decision Rule 4 are:

- analytical data from surface soils and subsurface soils adjacent to the process sewer line.

The sampling data needs for Decision Rule 4 will be obtained during the ESC Phase 2, if necessary.

Decision Rule 5 relates to the identification of extent of contamination in groundwater.

Decision Rule 5: If the concentration of any USC in groundwater from the water table aquifer exceeds the screening level for that individual USC, then determine whether the unit is the source of the contamination and, if so, the extent of that contamination.

Data needs to support Decision Rule 5 are:

- groundwater analytical data from cone penetrometer borings up and downgradient.

- hydrogeologic and lithologic unit characteristics.

- groundwater analytical data from beneath the unit and vicinity.

Information and data gathered in support of Decision Rule 5 will provide groundwater flow direction and thickness of the water table aquifer which must be known to determine optimal groundwater sample locations for the determination of the extent of USCs in unit 
groundwater. In addition, the USCs and their risk-based cleanup levels identified in support of Decision Rule 2 will provide the data necessary to aid in the determination of the extent of groundwater contamination.

\subsection{UNIT ASSESSMENT OBJECTIVES}

The primary purpose of characterization sampling is to define the nature and extent of hazardous substance release to environmental media within and surrounding the MSSB. The unit assessment sampling plan has been designed to meet the following objectives which support the unit uncertainties and data needs identified in Table 4.1:

- Evaluate the unit-specific background or reference levels for organics and inorganics in all media of concern;

- Define the subsurface lithology down to the first confining unit;

- Determine the depth to groundwater and groundwater flow direction in the water table aquifer;

- Determine the nature and extent of contamination related to the MSSB and process sewer lines;

- Collect data needed to support the human health and ecological baseline risk assessment; and

- Collect data to support treatability/feasibility study.

Table 4.1 outlines the specific data needs of the MSSB. The data needs were determined by comparing the Unit Assessment Objectives to the Conceptual Site Model and the Data Quality Objectives, which are described in Chapter 3. Data needs include: unitspecific background evaluations for surface soil, subsurface soil, and groundwater; unitspecific characterization of surface soil, subsurface soil deep subsurface soil, and groundwater; and unit-specific lithological characterization.

\subsection{UNIT ASSESSMENT ANALYTES}

During the Unit Assessment, environmental and QA/QC samples will be analyzed for volatile organic compounds, semivolatile organic compounds, pesticides, PCBs, metals, total organic carbon, radionuclide indicator (gross alpha and non-volatile beta), and total petroleum hydrocarbons (TPH). These compounds were chosen based upon the results of past sampling and analysis at the MSSB and upon the historical use of the unit. Each compound is listed in Table 4.2, with analytical methods and quantitation limits for water and soil. 
Records of past use of the MSSB indicate that radioactive substances were not disposed of there. In addition, previous analysis of soils within the MSSB and of groundwater from nearby monitoring wells indicate there is no significant radionuclidic contamination. Therefore, speciation will be conducted during Phase 2 only if Phase 1 gross alpha/non-volatile beta radiological indicators are positive $(20 \mathrm{pCi} / g m$ gross alpha, 50 $\mathrm{pCi} / \mathrm{gm}$ non-volatile beta).

\subsection{SAMPLING PLAN}

\subsubsection{Background Characterization}

The purpose of the background characterization is to obtain unit-specific reference data for soil and groundwater quality. The unit-specific background concentrations will be determined by collection of soil and groundwater samples from locations presumed to be unaffected by unit activities. The unit-specific background is defined as the average of the concentrations measured in these samples for each respective parameter in each respective media. Background locations are shown in Figure 4-4 and are listed in Table 4.3 by medium.

\section{Groundwater (Phase 2)}

Groundwater samples that will be used to characterize reference data for groundwater quality will be selected using, as much as possible, pre-existing monitoring wells. Background groundwater samples will be collected from two monitoring wells (AOB3 and MSB35) and from two cone penetrometer location (AOB-PT1 and AOB-PT2) as shown in Figure 4-4. Groundwater flow directions in the water table aquifer, the "M-Area" aquifer zone, are to the west-northwest in the vicinity of the MSSB (WSRC, 1995b). Upgradient samples from the locations indicated in Figure 4-4 will help to distinguish between contamination to groundwater as a result of activities in the study area and contamination in the groundwater before it enters the area.

Background groundwater samples will be analyzed for the following:

- USCs as determined by Phase 1 .

[NOTE: A threshold for turbidity will be established toward assuring the integrity of all groundwater samples.] 


\section{Soil (Phase 1)}

The soil borings will be advanced to a maximum depth of 4 feet by hand auger or direct push. A total of 12 soil samples will be collected for background characterization: 6 surface soils ( 0 to $\left.1^{\prime}\right)$ and 6 subsurface soils from 1 to $4^{\prime}$. These intervals are proposed to support human health and ecological risk evaluation. Background soil samples will be analyzed for:

- TAL,

- TCL/TIC,

- gross alpha/non-volatile beta radiological indicators,

- $\mathrm{pH}$,

- TPH, and

- TOC.

Unit-specific background samples will be collected from 6 borings as shown in Figure 4-4, for comparative purposes. Statistical comparisons of the background data and the onunit data will be performed to determine the level and extent of contamination present. Samples from 6 soil borings will be necessary to enhance the statistical analysis results. For comparative purposes, it is essential that background samples be collected from environments and soil horizons that are geochemically and/or ecologically similar to the unit and that are exposed to the same gross environmental conditions as soils within the unit. For this reason, background sampling locations shown in Figure 4-4 are tentative and siting within appropriate soil series will be conducted during a field reconnaissance.

\subsubsection{Motor Shops Seepage Basin Sampling Plan}

Sample locations for the MSSB are shown in Figure 4-5 and are listed in Table 4.5 by medium.

\section{Lithologic Characterization (Phase 2)}

ESC Phase 2 Lithologic characterization of the MSSB will be done using Cone Penetrometer (CPT) techniques. If the CPT is incapable of penetrating to required depths, a hydropunch may be used. One CPT probe (AOB-PT3) will be pushed in the center of the basin (Figure 4-5). Other CPT locations will be determined through the ESC process, as necessary. The CPT data (to include tip resistance, sleeve friction, friction ratio, and pore pressure) will be used to characterize the lithology for the immediate area down to the top of the first confining unit, the "Green Clay". CPT data will be collected following the procedures found in Chapter 9 of Hydrogeologic Data Collection Procedures and Specifications (WSRC, 1993b). 
An objective of this part of ESC is to collect unit specific hydrostratigraphic data utilizing CPT and continuous core logging. Lithologic data of the strata from the ground surface to, and including, the first confining unit will be obtained from both the continuous coring and the CPT. Depth and permeability characteristics of the first confining unit will be determined. Previous lithologic investigations in this area indicate that the first competent confining unit is likely Confining Unit IIA-IIB (Gordon Confining Unit or "Green Clay"). These data will provide the information necessary to conduct subsequent assessment activities for groundwater analyses and contaminant plume investigation.

Continuous core logging will be conducted at AOB-PT3 (Figure 4-5) to provide correlation confidence between CPT locations and confirmation of the CPT output. It is planned that the corehole will be drilled and proceed until the first confining unit is encountered (i.e., Gordon Confining Unit; IIA-IIB). Unit specific lithologic data will be recorded during the installation of the boreholes. Soil samples will be described and classified in accordance with the Unified Soil Classification System (ASTM D2487-92).

A suite of geophysical logs will be collected from within the drill casing or a temporary piezometer. The logs will include natural gamma, density (gamma-gamma), porosity (neutron), and electrical conductivity (induction). This combination of geophysical and continuous core logs will be used to refine and verify the CPT measurements.

The piezocone will be pushed to the first confining unit at each CPT location. A combination of tip pressure and sleeve resistance will be used to identify and map the top of the Green Clay. Geotechnical parameters to be measured with the piezocone will include sleeve resistance/tip pressure ratio and pore pressure. Subsequent to the completion of each push, each hole will be pressure grouted as the rod is pulled out of the hole utilizing a grout module or tremie pipe.

\section{Groundwater Sampling (Phase 2)}

Groundwater samples from the MSSB area will be collected from 2 existing monitoring wells, AOB1 and AOB2, and from the CPT location, AOB-PT3, discussed above. Figure 4-5 shows the locations of the monitoring wells and the CPT location. Monitoring well AOB1 is located south of the basin and AOB2 is located adjacent to the basin on its eastern side. The location for the CPT probe AOB-PT3 was chosen to determine whether contamination exists in groundwater immediately beneath the basin. Additional CPT locations will be selected by the ESC process. A representative sample of groundwater will be collected from each CPT probe at the water table.

The water table in the immediate area is approximately 150 feet below land surface (WSRC, 1995c), however, the depth will be verified using CPT characterization data, existing well data, and other hydrogeologic data available for the area. The groundwater samples will be analyzed for USCs. 


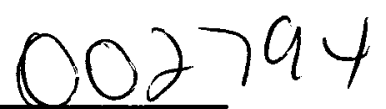

Once the extent of groundwater contamination coming from the MSSB has been determined, additional wells will be installed as necessary to collect definitive samples. These samples will be collected using low-flow pump techniques and will be analyzed for USCs.

Field hydraulic permeability tests (slug tests) will be performed on all monitoring wells and piezometers determined to be in a condition suitable to provide representative data. These tests will be performed to estimate the hydraulic conductivity $(K)$ of the water table aquifer within the vicinity of the unit. Rising and falling head tests will be performed on each well tested, and the data analyzed using the Bouwer and Rice (1976) and Bouwer (1989) method.

\section{Soil Sampling}

The objective of the soil sampling in the MSSB is to determine if hazardous substances are present within the basin and, if so, whether contamination has spread beyond the basin boundaries due to basin overflow or other mechanisms. If such a release has occurred, then the horizontal and vertical extent of contamination will be determined. All soil borings will be advanced by hand auger or by direct push. Adequate sample volume will be obtained for all analyses. These procedures will follow the guidelines for soil boring investigations as detailed in Chapter 6 of Hydrogeologic Data Collection Procedures and Specifications (WSRC, 1993b). ESC Phase 1 soil samples will be analyzed for the following compounds:

- TCL/TIC,

- TAL,

- gross alpha/non-volatile beta radiological indicators,

- $\mathrm{pH}$,

- TPH, and

- TOC.

If it is determined during ESC Phase 1 that contamination has spread beyond the MSSB, then additional boreholes will be positioned laterally to determine the horizontal extent of contaminant migration during ESC Phase 2. Phase 2 analysis is dependent upon USC determination as a result of Phase 1. Additional samples will be collected along the process sewer lines to determine whether the sewer lines have had an impact on the environment. If contamination is detected in any sample, another borehole will be positioned laterally to define the horizontal extent of contamination. Samplings at this contingent location will start 1 foot above the depth where contamination was first detected in the initial borchole and will continue at 2 -foot intervals until two consecutive samples 
screen "clean", or to a maximum of 8 feet below the depth at which sampling was initiated. Additional lateral boreholes may be similarly located if contamination is detected in any sample interval in the preceding borehole.

The method for determining the vertical extent of contamination will follow the logic illustrated in Figure 4-6. Vertical sampling will continue at 2-foot intervals until two consecutive samples screen below or at background levels or until groundwater is encountered. At this point, sampling will cease. Samples will be screened for volatile organics using an HNu or OVA. The last sample that screens "clean" will also be sent for USC analysis to confirm the absence of contamination.

\subsubsection{Investigative Derived Waste Identification, Generation, and Management}

Sampling activities associated with the MSSB may generate both aqueous and nonaqueous investigative derived waste (IDW) which will be managed in accordance with the IDW Management Plan (WSRC, 1994b). Aqueous IDW may consist of decontamination rinseates and monitoring well purge water. Non-aqueous IDW many consist of personal protective equipment (PPE) and excess soil from borings and augering within the unit. PPE will be decontaminated and reused, where possible. Excess soil from background samples will be considered clean and discharged to the ground where generated. Additional IDW specific information will be documented in an IDW Management Strategy which will be maintained in the project record file. 
RFI/RI Work Plan for the

Motor Shops Seepage Basin

Table 4.1. Unit Data Needs and Proposed Characterization Activities 716-A Motor Shops Seepage Basin

\begin{tabular}{lc}
\hline \hline Unit Component & \multicolumn{1}{c}{ Data Needs } \\
\hline Surface Soil & $\begin{array}{c}\text { Unit-specific Surface Soi } \\
\text { Background Evaluation }\end{array}$ \\
& \\
& \\
& Unit-specific Surface Soi \\
& Characterization \\
& \\
& \\
Subsurface Soil & Unit-specific Subsurface \\
(Phase 1) & Soil Background \\
& Evaluation
\end{tabular}

Unit-specific Subsurface Soil Characterization

$\begin{array}{ll}\text { Deep Subsurface } & \begin{array}{l}\text { Vertical Extent of } \\ \text { Subsurface Soil } \\ \text { Soil }\end{array} \\ \text { Contamination }\end{array}$

Purpose: To establish background concentrations for comparison to onunit concentrations. Collect and analyze soil samples from the 0 to 1 foot interval at six background locations for TCL/TIC, TAL, gross alpha/non-volatile beta radiological indicators, TPH, TOC, and $\mathrm{pH}$.

Purpose: To characterize unit surface soils in order to estimate potential risks to current human and ecological receptors (terrestrial receptors). Collect and analyze soil samples from the 0 to 1 foot interval at 6 locations within the basin for TCL/TIC, TAL, gross alpha/non-volatile beta radiological indicators, TPH, TOC, and $\mathrm{pH}$.

Purpose: To establish background concentrations for comparison to onunit concentrations. Collect and analyze soil samples from the 1 to 4 foot depth at six background locations for TCL/TIC, TAL, gross alpha/nonvolatile beta radiological indicators, TPH, TOC, and $\mathrm{pH}$.

Purpose: To characterize unit soils in order to estimate potential risks to future ecological receptors and human receptors. Collect and analyze soil samples from the 1 to 4 foot depth at 6 locations within the basin for TCL/TIC, TAL, gross alpha/non-volatile beta radiological indicators, TPH, TOC, and $\mathrm{pH}$.

Purpose: To determine the vertical extent of contamination, if present. Collect and analyze the deepest soil sample from locations determined by the ESC process and analyze for USCs to determine extent of contamination. 
Table 4.1. (Continued) Unit Data Needs and Proposed Characterization Activities 716-A Motor Shops Seepage Basin

\begin{tabular}{|c|c|c|}
\hline Unit Component & Data Needs & Characterization Activity \\
\hline \multirow[t]{2}{*}{$\begin{array}{l}\text { Groundwater } \\
\text { (Phase 2) }\end{array}$} & $\begin{array}{l}\text { Unit-specific Groundwater } \\
\text { Background Evaluation }\end{array}$ & $\begin{array}{l}\text { Purpose: To establish upgradient } \\
\text { concentrations for comparison to } \\
\text { downgradient concentrations. Collect } \\
\text { and analyze groundwater samples from } \\
\text { two existing background monitoring } \\
\text { wells, AOB3, and MSB35, and from } \\
\text { two background CPT locations for } \\
\text { USCs. }\end{array}$ \\
\hline & $\begin{array}{l}\text { Horizontal and Vertical } \\
\text { Extent of Contamination }\end{array}$ & $\begin{array}{l}\text { Purpose: To characterize the extent of } \\
\text { groundwater contamination, if present, } \\
\text { and to estimate potential risks to future } \\
\text { human receptors. Collect and analyze } \\
\text { groundwater samples from CPT } \\
\text { locations determined by the ESC } \\
\text { process for USCs. }\end{array}$ \\
\hline $\begin{array}{l}\text { Lithology } \\
\text { (Phase 2) }\end{array}$ & $\begin{array}{l}\text { Unit-Specific Lithological } \\
\text { Characterization to the } \\
\text { First Confining Unit }\end{array}$ & $\begin{array}{l}\text { Purpose: To provide lithological } \\
\text { characterization to the first confining } \\
\text { unit for the RFI. Collect lithologic data } \\
\text { at one CPT location inside the basin } \\
\text { and at other locations, if determined } \\
\text { necessary by the ESC process. }\end{array}$ \\
\hline
\end{tabular}


RFI/RI Work Plan for the

WSRC-RP-96-00111, Revision 0

Motor Shops Seepage Basin

March 1996

Table 4.2. Analytical Parameters for 716-A Motor Shops Seepage Basin

\begin{tabular}{|c|c|c|c|c|}
\hline \multirow[b]{2}{*}{ Compound } & \multirow[b]{2}{*}{$\begin{array}{c}\text { CAS } \\
\text { Number } \\
\end{array}$} & \multicolumn{2}{|c|}{ Quantitation Limits* } & \multirow{2}{*}{$\begin{array}{c}\text { Analytical } \\
\text { Method } \\
\text { (SW-846**) }\end{array}$} \\
\hline & & $\begin{array}{c}\begin{array}{c}\text { Water } \\
\text { ug/l }\end{array} \\
\end{array}$ & $\begin{array}{c}\text { Soil (a) } \\
\text { ug/kg }\end{array}$ & \\
\hline Volatile Organics: (TCL) & $74-87-3$ & 10 & 10 & 8260 \\
\hline Chloromethane & $74-83-9$ & 10 & 10 & 8260 \\
\hline Bromomethane & $74-83-9$ & 10 & 10 & 8260 \\
\hline Vinyl Chloride & $75-01-4$ & 5 & 10 & 8260 \\
\hline Chloroethane & $75-00-3$ & 10 & 10 & 8260 \\
\hline Methylene Chloride & $75-09-2$ & 5 & 5 & 8260 \\
\hline Acetone & 67-64-1 & 10 & 10 & 8260 \\
\hline Carbon Disulfide & $75-15-0$ & 5 & 5 & 8260 \\
\hline 1,1-Dichloroethylene & $75-35-4$ & 5 & 5 & 8260 \\
\hline 1,1-Dichloroethane & $75-34-3$ & 5 & 5 & 8260 \\
\hline 1,2-Dichloroethylene (total) & $540-59-0$ & 5 & 5 & 8260 \\
\hline Chloroform & $67-66-3$ & 5 & 5 & 8260 \\
\hline 1,2-Dichloroethane & $107-06-2$ & 5 & 5 & 8260 \\
\hline 2-Butanone & 78-93-3 & 10 & 10 & 8260 \\
\hline 1,1,1-Trichloroethane & $71-55-6$ & 5 & 5 & 8260 \\
\hline Carbon Tetrachloride & $56-23-5$ & 5 & 5 & 8260 \\
\hline Vinyl Acetate & $108-05-04$ & 10 & 10 & 8260 \\
\hline Bromodichloromethane & $75-27-4$ & 5 & 5 & 8260 \\
\hline $1,1,2,2$-Tetrachloroethane & $79-34-5$ & 5 & 5 & 8260 \\
\hline 1,2-Dichloropropane & $78-87-5$ & 5 & 5 & 8260 \\
\hline trans-1,3-Dichloropropene & $10061-02-6$ & 5 & 5 & 8260 \\
\hline Trichloroethylene & 79-01-6 & 5 & 5 & 8260 \\
\hline Dibromochloromethane & $124-48-1$ & 5 & 5 & 8260 \\
\hline 1,1,2-Trichloroethane & $79-00-5$ & 5 & 5 & 8260 \\
\hline Benzene & $71-43-2$ & 5 & 5 & 8260 \\
\hline cis-1,3-Dichloropropene & $10061-01-5$ & 5 & 5 & 8260 \\
\hline Bromoform & $75-25-2$ & 5 & 5 & 8260 \\
\hline 4-Methyl-2-Pentanone & $108-10-1$ & 10 & 10 & 8260 \\
\hline 2-Hexanone & $591-78-6$ & 10 & 10 & 8260 \\
\hline Tetrachloroethylene & $127-18-4$ & 5 & 5 & 8260 \\
\hline Toluene & $108-88-3$ & 5 & 5 & 8260 \\
\hline Chlorobenzene & $108-90-7$ & 5 & 5 & 8260 \\
\hline Ethylbenzene & $100-41-4$ & 5 & 5 & 8260 \\
\hline Styrene & $100-42-5$ & 5 & 5 & 8260 \\
\hline Xylene (total) & $1330-20-7$ & 5 & 5 & 8260 \\
\hline Tentatively Identified Compounds (TIC) & -.. & --- & -- & 8260 \\
\hline
\end{tabular}


RFI/RI Work Plan for the

WSRC-RP-96-00111, Revision 0

Motor Shops Seepage Basin

March 1996

Table 4.2. (Continued) Analytical Parameters for 716-A Motor Shops Seepage Basin

\begin{tabular}{|c|c|c|c|c|}
\hline \multirow[b]{2}{*}{ Compound } & \multirow[b]{2}{*}{$\begin{array}{c}\text { CAS } \\
\text { Number }\end{array}$} & \multicolumn{2}{|c|}{ Quantitation Limits* } & \multirow{2}{*}{$\begin{array}{c}\text { Analytical } \\
\text { Method } \\
(\text { SW-846**) } \\
\end{array}$} \\
\hline & & $\begin{array}{c}\text { Water } \\
\text { ug/l }\end{array}$ & $\begin{array}{c}\text { Soil (a) } \\
\mathbf{u g} / \mathbf{k g}\end{array}$ & \\
\hline \multicolumn{5}{|c|}{ Semi-Volatile Compounds: (TCL) } \\
\hline Phenol & $108-95-2$ & 10 & 330 & 8270 \\
\hline bis(2-chloroethyl)ether & $111-44-4$ & 10 & 330 & 8270 \\
\hline 2-Chlorophenol & $95-57-8$ & 10 & 10 & 8270 \\
\hline 1,3-Dichlorobenzene & $541-73-1$ & 10 & 330 & 8270 \\
\hline 1,4-Dichlorobenzene & $106-46-7$ & 10 & 330 & 8270 \\
\hline Benzyl alcohol & $100-51-6$ & 10 & 330 & 8270 \\
\hline 1,2-Dichlorobenzene & $95-50-1$ & 10 & 330 & 8270 \\
\hline 2-Methylphenol & $95-48-7$ & 10 & 330 & 8270 \\
\hline bis(2-chloroisopropyl)ether & $108-60-1$ & 10 & 330 & 8270 \\
\hline 4-Methylphenol & $106-44-5$ & 10 & 330 & 8270 \\
\hline N-Nitroso-di-n-propylamine & $621-64-7$ & 10 & 330 & 8270 \\
\hline Hexachloroethane & $67-72-1$ & 10 & 330 & 8270 \\
\hline Nitrobenzene & $98-95-3$ & 10 & 330 & 8270 \\
\hline Isophorone & $78-59-1$ & 10 & 330 & 8270 \\
\hline 2-Nitrophenol & $88-75-5$ & 10 & 330 & 8270 \\
\hline 2,4-Dimethylphenol & $105-67-9$ & 10 & 330 & 8270 \\
\hline Benzoic acid & $65-85-0$ & 50 & 1600 & 8270 \\
\hline bis(2-chloroethoxy)methane & $111-91-1$ & 10 & 330 & 8270 \\
\hline 2,4-Dichlorophenol & $120-83-2$ & 10 & 330 & 8270 \\
\hline 1,2,4-Trichlorobenzene & $120-82-1$ & 10 & 330 & 8270 \\
\hline Naphthalene & $91-20-3$ & 10 & 330 & 8270 \\
\hline 4-Chloroaniline & $106-47-8$ & 10 & 330 & 8270 \\
\hline Hexachlorobutadiene & $87-68-3$ & 10 & 330 & 8270 \\
\hline 4-Chloro-3-methylphenol & $59-50-7$ & 10 & 330 & 8270 \\
\hline 2-Methylnaphthalene & $91-57-6$ & 10 & 330 & 8270 \\
\hline Hexachlorocyclopentadiene & $77-47-4$ & 10 & 330 & 8270 \\
\hline 2,4,6-Trichlorophenol & $88-06-2$ & 10 & 330 & 8270 \\
\hline 2,4,5-Trichlorophenol & $95-95-4$ & 50 & 1600 & 8270 \\
\hline 2-Chloronaphthalene & $91-58-7$ & 10 & 330 & 8270 \\
\hline 2-Nitroaniline & $88-74-4$ & 50 & 1600 & 8270 \\
\hline Dimethylphthalate & $131-11-3$ & 10 & 330 & 8270 \\
\hline Acenaphthylene & $208-96-8$ & 10 & 330 & 8270 \\
\hline 2,6-Dinitrotoluene & $606-20-2$ & 10 & 330 & 8270 \\
\hline 3-Nitroaniline & $99-09-2$ & 50 & 1600 & 8270 \\
\hline Acenaphthene & $83-32-9$ & 10 & 330 & 8270 \\
\hline 2,4-Dinitrophenol & $51-28-5$ & 50 & 1600 & 8270 \\
\hline 4-Nitrophenol & $100-02-7$ & 50 & 1600 & 8270 \\
\hline
\end{tabular}


RFI/RI Work Plan for the

WSRC-RP-96-00111, Revision 0

Motor Shops Seepage Basin

March 1996

Table 4.2. (Continued) Analytical Parameters for 716-A Motor Shops Seepage Basin

\begin{tabular}{|c|c|c|c|c|}
\hline \multirow[b]{2}{*}{ Compound } & \multirow[b]{2}{*}{$\begin{array}{c}\text { CAS } \\
\text { Number }\end{array}$} & \multicolumn{2}{|c|}{ Quantitation Limits* } & \multirow{2}{*}{$\begin{array}{c}\text { Analytical } \\
\text { Method } \\
(\mathbf{S W - 8 4 6 * )}) \\
\end{array}$} \\
\hline & & $\begin{array}{c}\begin{array}{c}\text { Water } \\
\text { ug/l }\end{array} \\
\end{array}$ & $\begin{array}{c}\text { Soil (a) } \\
\mathbf{u g} / \mathbf{k g}\end{array}$ & \\
\hline Dibenzofuran & $132-64-9$ & 10 & 330 & 8270 \\
\hline 2,4-Dinitrotoluene & $121-14-2$ & 10 & 330 & 8270 \\
\hline Diethylphthalate & $84-66-2$ & 10 & 330 & 8270 \\
\hline 4-Chlorophenyl-phenylether & $7005-72-3$ & 10 & 330 & 8270 \\
\hline Fluorene & $86-73-7$ & 10 & 330 & 8270 \\
\hline 4-Nitroaniline & $100-01-6$ & 50 & 1600 & 8270 \\
\hline 4,6-Dinitro-2-methylphenol & $534-52-1$ & 50 & 1600 & 8270 \\
\hline N-Nitrosodiphenylamine (1) & $86-30-6$ & 10 & 330 & 8270 \\
\hline 4-Bromophenyl-phenylether & $101-55-3$ & 10 & 330 & 8270 \\
\hline Hexachlorobenzene & $118-74-1$ & 10 & 330 & 8270 \\
\hline Pentachlorophenol & $87-86-5$ & 50 & 1600 & 8270 \\
\hline Phenanthrene & $85-01-8$ & 10 & 330 & 8270 \\
\hline Anthracene & $120-12-7$ & 10 & 330 & 8270 \\
\hline Di-n-butylphthalate & $84-74-2$ & 10 & 330 & 8270 \\
\hline Fluoranthene & $206-44-0$ & 10 & 330 & 8270 \\
\hline Pyrene & $129-00-0$ & 10 & 330 & 8270 \\
\hline Butylbenzylphthalate & $85-68-7$ & 10 & 330 & 8270 \\
\hline 3,3'-Dichlorobenzidine & 91-94-1 & 20 & 660 & 8270 \\
\hline Benzo(a)anthracene & $56-55-3$ & 10 & 330 & 8270 \\
\hline Chrysene & $218-01-9$ & 10 & 330 & 8270 \\
\hline bis(2-ethylhexyl)phthalate & $117-81-7$ & 10 & 330 & 8270 \\
\hline Di-n-octylphthalate & $117-84-0$ & 10 & 330 & 8270 \\
\hline Benzo(b)fluoranthene & $205-9902$ & 10 & 330 & 8270 \\
\hline Benzo(k)fluoranthene & $207-08-9$ & 10 & 330 & 8270 \\
\hline Benzo(a)pyrene & $50-32-8$ & 10 & 330 & 8270 \\
\hline Indeno(1,2,3-cd)pyrene & $193-39-5$ & 10 & 330 & 8270 \\
\hline $\operatorname{Dibenz}(\mathrm{a}, \mathrm{h})$ anthracene & $53-70-3$ & 10 & 330 & 8270 \\
\hline Benzo(g,h,i)perylene & $191-24-2$ & 10 & 330 & 8270 \\
\hline Tentatively Identified Compounds (TIC) & --- & --- & $\cdots$ & 8270 \\
\hline \multicolumn{5}{|l|}{ Pesticides/PCBs: (TCL) } \\
\hline alpha-BHC & $319-84-6$ & 0.05 & 8 & 8080 \\
\hline beta-BHC & $319-85-7$ & 0.05 & 8 & 8080 \\
\hline delta-BHC & $319-86-8$ & 0.05 & 8 & 8080 \\
\hline gamma-BHC (Lindane) & $58-89-9$ & 0.05 & 8 & 8080 \\
\hline Heptachlor & $76-44-8$ & 0.05 & 8 & 8080 \\
\hline Aldrin & $309-00-2$ & 0.05 & 8 & 8080 \\
\hline Heptachlor epoxide & $1024-57-3$ & 0.05 & 8 & 8080 \\
\hline Endosulfan I & $959-98-8$ & 0.05 & 8 & 8080 \\
\hline
\end{tabular}


RFI/RI Work Plan for the

WSRC-RP-96-00111, Revision 0

Motor Shops Seepage Basin

March 1996

Table 4.2. (Continued) Analytical Parameters for 716-A Motor Shops Seepage Basin

\begin{tabular}{|c|c|c|c|c|}
\hline \multirow[b]{2}{*}{ Compound } & \multirow[b]{2}{*}{$\begin{array}{c}\text { CAS } \\
\text { Number } \\
\end{array}$} & \multicolumn{2}{|c|}{ Quantitation Limits* } & \multirow{2}{*}{$\begin{array}{c}\text { Analytical } \\
\text { Method } \\
\text { (SW-846**) } \\
\end{array}$} \\
\hline & & $\begin{array}{c}\begin{array}{c}\text { Water } \\
\text { ug/1 }\end{array} \\
\end{array}$ & $\begin{array}{c}\text { Soil (a) } \\
\text { ug/kg }\end{array}$ & \\
\hline Dieldrin & $60-57-1$ & 0.1 & 16 & 8080 \\
\hline $4,4^{\prime}-\mathrm{DDE}$ & $72-55-9$ & 0.1 & 16 & 8080 \\
\hline Endrin & $72-20-8$ & 0.1 & 16 & 8080 \\
\hline Endosulfan II & $33213-65-9$ & 0.1 & 16 & 8080 \\
\hline $4,4^{\prime}-\mathrm{DDD}$ & $72-54-8$ & 0.1 & 16 & 8080 \\
\hline Endosulfan sulfate & $1031-07-8$ & 0.1 & 16 & 8080 \\
\hline 4,4'-DDT & $50-29-3$ & 0.1 & 16 & 8080 \\
\hline Methoxychlor & $72-43-5$ & 0.5 & 80 & 8080 \\
\hline Endrin ketone & $53494-70-5$ & 0.1 & 16 & 8080 \\
\hline alpha-chlordane & $5103-71-9$ & 0.5 & 80 & 8080 \\
\hline gamma-chlordane & $5103-74-2$ & 0.5 & 80 & 8080 \\
\hline Toxaphene & $8001-35-2$ & 1 & 160 & 8080 \\
\hline Aroclor-1016 & $12674-11-2$ & 0.5 & 80 & 8080 \\
\hline Aroclor-1221 & $11104-28-2$ & 0.5 & 80 & 8080 \\
\hline Aroclor-1232 & $11141-16-5$ & 0.5 & 80 & 8080 \\
\hline Aroclor-1242 & $53469-21-9$ & 0.5 & 80 & 8080 \\
\hline Aroclor-1248 & $12672-29-6$ & 0.5 & 80 & 8080 \\
\hline Aroclor- 1254 & $11097-69-1$ & 1 & 160 & 8080 \\
\hline Aroclor- 1260 & $11096-82-5$ & 1 & 160 & 8080 \\
\hline \multicolumn{5}{|l|}{ Metals: (TAL) } \\
\hline Aluminum & $7429-90-5$ & 200 & 200 & 6010 \\
\hline Antimony & $7440-36-0$ & 60 & 60 & 7041 \\
\hline Arsenic & $7440-38-2$ & 10 & 10 & 7060 \\
\hline Barium & $7440-39-3$ & 200 & 200 & 6010 \\
\hline Beryllium & $7440-41-7$ & 5 & 5 & 6010 \\
\hline Cadmium & $7440-43-9$ & 5 & 5 & 7131 \\
\hline Calcium & $7440-70-2$ & 5000 & 5000 & 6010 \\
\hline Chromium & $7440-47-3$ & 10 & 10 & 6010 \\
\hline Cobalt & $7440-48-4$ & 50 & 50 & 6010 \\
\hline Copper & $7440-50-8$ & 25 & 25 & 6010 \\
\hline Cyanide & $57-12-5$ & 25 & 500 & 9010 \\
\hline Iron & $7439-8906$ & 100 & 100 & 6010 \\
\hline Lead & $7439-92-1$ & 5 & 5 & 7421 \\
\hline Magnesium & $7439-95-4$ & 5000 & 5000 & 6010 \\
\hline Manganese & $7439-96-5$ & 15 & 15 & 6010 \\
\hline Mercury & $7439-97-6$ & 0.2 & 0.2 & 7470 \\
\hline Nickel & $7440-02-0$ & 40 & 40 & 6010 \\
\hline Potassium & $7440-09-7$ & 5000 & 5000 & 6010 \\
\hline
\end{tabular}


RFI/RI Work Plan for the

WSRC-RP-96-00111, Revision 0

Motor Shops Seepage Basin

March 1996

Table 4.2. (Continued) Analytical Parameters for 716-A Motor Shops Seepage Basin

\begin{tabular}{lcccc}
\hline \hline Compound & CAS & $\begin{array}{c}\text { Quantitation Limits* } \\
\text { Water } \\
\text { Number }\end{array}$ & $\begin{array}{c}\text { ug/l } \\
\text { Soil (a) } \\
\text { ug/kg }\end{array}$ & $\begin{array}{c}\text { Analytical } \\
\text { Method } \\
(\mathbf{S W - 8 4 6 * *})\end{array}$ \\
\hline Selenium & $7782-49-2$ & 5 & 5 & 7740 \\
Silver & $7440-22-4$ & 10 & 10 & 6010 \\
Sodium & $7440-23-5$ & 5000 & 5000 & 6010 \\
Thallium & $7440-28-0$ & 10 & 10 & 7841 \\
Vanadium & $7440-62-2$ & 50 & 50 & 6010 \\
Zinc & $7440-66-6$ & 20 & 20 & 6010 \\
\hline
\end{tabular}

\begin{tabular}{|c|c|c|c|c|}
\hline \multirow[b]{2}{*}{ Compound } & & \multicolumn{2}{|c|}{ Quantitation Limits* } & \multirow{2}{*}{$\begin{array}{l}\text { Analytical } \\
\text { Method }^{* *}\end{array}$} \\
\hline & & $\begin{array}{c}\text { Water } \\
\text { pCi/l } \\
\end{array}$ & $\begin{array}{l}\text { Soil (a) } \\
\text { pCi/g }\end{array}$ & \\
\hline \multicolumn{5}{|l|}{ Radiochemistry: } \\
\hline Gross Alpha & & 1.5 & 4 & GFPC \\
\hline Non-Volatile Beta & & 2 & 10 & GFPC \\
\hline Tritium & & 700 & 6 & LS \\
\hline \multicolumn{5}{|l|}{ Conventionals: } \\
\hline $\mathrm{pH}$ & -- & -- & $-\cdots$ & --- \\
\hline \multicolumn{5}{|l|}{ Temperature } \\
\hline \multicolumn{5}{|l|}{ Specific Conductance } \\
\hline \multicolumn{5}{|l|}{ Turbity } \\
\hline Total Hardness & -- & --- & --- & -- \\
\hline Total Organic Carbon (TOC) & $-\cdots$ & -..- & --- & -.- \\
\hline Acid Volatile Sulfides (AVS) & -- & $\cdots$ & -- & --- \\
\hline Insitu Dissolved Solvent & --- & -.. & -.- & --. \\
\hline
\end{tabular}

(1) Cannot be separated from Diphenylamine

* Specific quantitation limits are highly matrix dependent.

The quantitation limits listed herein are provided for guidance and may not be achievable.

** Analytical methods may vary between laboratories for the same analysis, but only EPA-sanctioned methods will be employed.

(a) Quantitation limits listed for soil/sediment are based on wet weight. The quantitation limits calculated by the laboratory for soil/sediment, calculated on dry weight basis will be higher. NA $=$ Not Applicable

ppt $=$ parts per trillion

GFPC $=$ Gas Flow Proportional Counting

LS $=$ Liquid Scintillation 
Table 4.3. Summary of Samples and Constituents to be Analyzed Background Characterization

\begin{tabular}{|c|c|c|c|c|c|}
\hline $\begin{array}{l}\text { Sample } \\
\text { Number }\end{array}$ & $\begin{array}{l}\text { Sampling } \\
\text { Instrument }\end{array}$ & $\begin{array}{c}\text { Sample } \\
\text { Type }\end{array}$ & $\begin{array}{c}\text { Sample } \\
\text { Location }\end{array}$ & $\begin{array}{c}\text { Sampling } \\
\text { Interval (Ft) }\end{array}$ & $\begin{array}{c}\text { Constituents } \\
\text { for Analysis (1) }\end{array}$ \\
\hline (Phase 2) & : & \multicolumn{2}{|c|}{ GROUNDWATER SAMPLE } & & \\
\hline $\begin{array}{l}\text { AOB3 (2) } \\
\text { MSB 35 (2) } \\
\text { AOB-PT1 } \\
\text { AOB-PT2 }\end{array}$ & $\begin{array}{c}\text { Low-flow Pump } \\
\text { Low-flow Pump } \\
\text { Direct Push } \\
\text { Direct Push }\end{array}$ & $\begin{array}{l}\text { Groundwater } \\
\text { Groundwater } \\
\text { Groundwater } \\
\text { Groundwater }\end{array}$ & $\begin{array}{l}\text { Upgradient } \\
\text { Upgradient } \\
\text { Upgradient } \\
\text { Upgradient }\end{array}$ & $\begin{array}{l}\text { NA } \\
\text { NA } \\
\text { NA } \\
\text { NA }\end{array}$ & $\begin{array}{l}\text { TBD } \\
\text { TBD } \\
\text { TBD } \\
\text { TBD }\end{array}$ \\
\hline (Phase 1) & & SOIL SA & LES & & \\
\hline ABK-SB1-1 & Hand Auger & Soil & Background & $0-1$ & $1,2,3,4,5,6$ \\
\hline ABK-SB1-2 & Hand Auger & Soil & Background & $1-4$ & $1,2,3,4,5,6$ \\
\hline ABK-SB2-1 & Hand Auger & Soil & Background & $0-1$ & $1,2,3,4,5,6$ \\
\hline ABK-SB2-2 & Hand Auger & Soil & Background & $1-4$ & $1,2,3,4,5,6$ \\
\hline ABK-SB3-1 & Hand Auger & Soil & Background & $0-1$ & $1,2,3,4,5,6$ \\
\hline ABK-SB3-2 & Hand Auger & Soil & Background & $1-4$ & $1,2,3,4,5,6$ \\
\hline ABK-SB4-1 & Hand Auger & Soil & Background & $0-1$ & $1,2,3,4,5,6$ \\
\hline ABK-SB4-2 & Hand Auger & Soil & Background & $1-4$ & $1,2,3,4,5,6$ \\
\hline ABK-SB5-1 & Hand Auger & Soil & Background & $0-1$ & $1,2,3,4,5,6$ \\
\hline ABK-SB5-2 & Hand Auger & Soil & Background & $1-4$ & $1,2,3,4,5,6$ \\
\hline ABK-SB6-1 & Hand Auger & Soil & Background & $0-1$ & $1,2,3,4,5,6$ \\
\hline ABK-SB6-2 & Hand Auger & Soil & Background & $1-4$ & $1,2,3,4,5,6$ \\
\hline
\end{tabular}

TBD - To be determined

(1) Constituents for Analysis as follows:

1. Target Compound List (TCL) and Tentatively Identified Compounds (TIC)

2. Target Analyte List (TAL)

3. Radiological Analytes

4. $\mathrm{pH}$

5. Total Petroleum Hydrocarbons (TPH)

6. TOC

(2) Two rounds of quarterly monitoring of these wells will be completed by WSRC prior to the investigation of these areas. 
Table 4.4. Summary of Samples and Constituents to be Analyzed 716-A Motor Shops Seepage Basin

\begin{tabular}{|c|c|c|c|c|c|}
\hline $\begin{array}{l}\text { Sample } \\
\text { Number }\end{array}$ & $\begin{array}{l}\text { Sampling } \\
\text { Instrument }\end{array}$ & $\begin{array}{c}\text { Sample } \\
\text { Type }\end{array}$ & $\begin{array}{c}\text { Sample } \\
\text { Location } \\
\end{array}$ & $\begin{array}{c}\text { Sampling } \\
\text { Interval (Ft) }\end{array}$ & $\begin{array}{c}\text { Constituents } \\
\text { for Analysis (1) }\end{array}$ \\
\hline (Phase 2) & \multicolumn{3}{|c|}{ GROUNDWATER SAMPLES } & & \\
\hline $\begin{array}{c}\text { AOB-PT3 } \\
\text { TBD } \\
\text { AOB1 (2) } \\
\text { AOB2 (2) } \\
\text { Additional } \\
\text { Monitoring Wells }\end{array}$ & $\begin{array}{c}\text { CPT } \\
\text { CPT } \\
\text { Low-flow Pump } \\
\text { Low-flow Pump } \\
\text { Low-flow Pump }\end{array}$ & $\begin{array}{l}\text { Groundwater } \\
\text { Groundwater } \\
\text { Groundwater } \\
\text { Groundwater } \\
\text { Groundwater }\end{array}$ & $\begin{array}{c}\text { On-unit } \\
\text { TBD } \\
\text { Downgradient } \\
\text { Downgradient } \\
\text { Downgradient }\end{array}$ & $\begin{array}{l}\text { NA } \\
\text { NA } \\
\text { NA } \\
\text { NA } \\
\text { NA }\end{array}$ & $\begin{array}{l}\text { TBD } \\
\text { TBD } \\
\text { TBD } \\
\text { TBD } \\
\text { TBD }\end{array}$ \\
\hline (Phase 1) & & SOILSAMP & & & \\
\hline $\begin{array}{c}\text { AOB-SB1-1 } \\
\text { AOB-SB1-2 } \\
\text { AOB-SB2-1 } \\
\text { AOB-SB2-2 } \\
\text { AOB-SB3-1 } \\
\text { AOB-SB3-2 } \\
\text { AOB-SB4-1 } \\
\text { AOB-SB4-2 } \\
\text { AOB-SB5-1 } \\
\text { AOB-SB5-2 } \\
\text { AOB-SB6-1 } \\
\text { AOB-SB6-2 } \\
\text { (Phase 2) }\end{array}$ & $\begin{array}{l}\text { Hand Auger } \\
\text { Hand Auger } \\
\text { Hand Auger } \\
\text { Hand Auger } \\
\text { Hand Auger } \\
\text { Hand Auger } \\
\text { Hand Auger } \\
\text { Hand Auger } \\
\text { Hand Auger } \\
\text { Hand Auger } \\
\text { Hand Auger } \\
\text { Hand Auger } \\
\text { Hand Auger }\end{array}$ & $\begin{array}{l}\text { Soil } \\
\text { Soil } \\
\text { Soil } \\
\text { Soil } \\
\text { Soil } \\
\text { Soil } \\
\text { Soil } \\
\text { Soil } \\
\text { Soil } \\
\text { Soil } \\
\text { Soil } \\
\text { Soil }\end{array}$ & $\begin{array}{l}\text { On-unit } \\
\text { On-unit } \\
\text { On-unit } \\
\text { On-unit } \\
\text { On-unit } \\
\text { On-unit } \\
\text { On-unit } \\
\text { On-unit } \\
\text { On-unit } \\
\text { On-unit } \\
\text { On-unit } \\
\text { On-unit }\end{array}$ & $\begin{array}{l}0-1 \\
1-4 \\
0-1 \\
1-4 \\
0-1 \\
1-4 \\
0-1 \\
1-4 \\
0-1 \\
1-4 \\
0-1 \\
1-4\end{array}$ & $\begin{array}{l}1,2,3,4,5,6 \\
1,2,3,4,5,6 \\
1,2,3,4,5,6 \\
1,2,3,4,5,6 \\
1,2,3,4,5,6 \\
1,2,3,4,5,6 \\
1,2,3,4,5,6 \\
1,2,3,4,5,6 \\
1,2,3,4,5,6 \\
1,2,3,4,5,6 \\
1,2,3,4,5,6 \\
1,2,3,4,5,6 \\
\text { TBD }\end{array}$ \\
\hline
\end{tabular}

TBD - To be determined

(1) Constituents for Analysis as follows:

1. Target Compound List (TCL) and Tentatively Identified Compounds (TIC)

2. Target Analyte List (TAL)

3. Radiological Analytes

4. $\mathrm{pH}$

5. Total Petroleum Hydrocarbons (TPH)

6. Total Organic Carbon (TOC)

(2) Two rounds of quarterly monitoring of these wells will be completed by WSRC prior to the investigation of these areas.

(3) Extent of vertical soil contamination will be assessed by screening soil samples for radionuclides and VOCs at 2 foot intervals below 4 feet.

Confirmatory samples will be taken when the screening indicates

that contamination is no longer present.

(4) Samplers will be prepared to take two contingency samples if suspect areas are identified during Phase 1. 
Table 4.5. Summary of Number of Field Samples and QA/QC Samples

\begin{tabular}{|c|c|c|c|c|c|c|c|}
\hline \multirow[b]{2}{*}{ Sample Type } & \multirow[b]{2}{*}{$\begin{array}{c}\text { Number of } \\
\text { Samples }\end{array}$} & \multicolumn{5}{|c|}{ QA/OC Samples } & \multirow[b]{2}{*}{$\begin{array}{c}\text { Total Number } \\
\text { of Samples }\end{array}$} \\
\hline & & $\begin{array}{c}\text { Trip } \\
\text { Blanks (1) }\end{array}$ & $\begin{array}{c}\text { Field } \\
\text { Blanks (2) }\end{array}$ & Duplicates (3) & Rinsates (4) & Split (5) & \\
\hline \multicolumn{8}{|l|}{ Background } \\
\hline $\begin{array}{l}\text { Soil (Phase 1) } \\
\text { Groundwater (Phase 2) }\end{array}$ & $\begin{array}{c}12 \\
4\end{array}$ & 1 & $\begin{array}{l}2 \\
1\end{array}$ & $\begin{array}{l}1 \\
1\end{array}$ & $\begin{array}{l}1 \\
1\end{array}$ & $\begin{array}{l}1 \\
0\end{array}$ & $\begin{array}{l}17 \\
8\end{array}$ \\
\hline ESC Phase 1 & & & & & & & \\
\hline Soil & 12 & & 2 & 1 & 1 & 1 & 17 \\
\hline $\begin{array}{l}\text { ESC Phase } 2 \\
\text { Soil } \\
\text { Groundwater }\end{array}$ & $\begin{array}{l}\text { TBD } \\
\text { TBD }\end{array}$ & $\begin{array}{l}\text { TBD } \\
\text { TBD }\end{array}$ & $\begin{array}{l}\text { TBD } \\
\text { TBD }\end{array}$ & $\begin{array}{l}\text { TBD } \\
\text { TBD }\end{array}$ & $\begin{array}{l}\text { TBD } \\
\text { TBD }\end{array}$ & $\begin{array}{l}\text { TBD } \\
\text { TBD }\end{array}$ & $\begin{array}{l}\text { TBD } \\
\text { TBD }\end{array}$ \\
\hline TOTALS & TBD & TBD & $\overline{\mathrm{TBD}}$ & TBD & TBD & TBD & TBD \\
\hline
\end{tabular}

(1) Estimated. The actual number of trip blanks will be determined in the field and will be equal to one per shipment for volatiles organics.

(2) Estimated. The number of field blanks collected will be approximately one per day of sampling.

(3) The combination of duplicate and split samples collected at the rate of one per every 10 samples (10\%).

(4) The number of rinsates collected will be approximately one per 20 samples (5\%).

(5) Splits will only be collected if a second laboratory is available for analyses.

TBD - To be determined (based on Phase I results) 


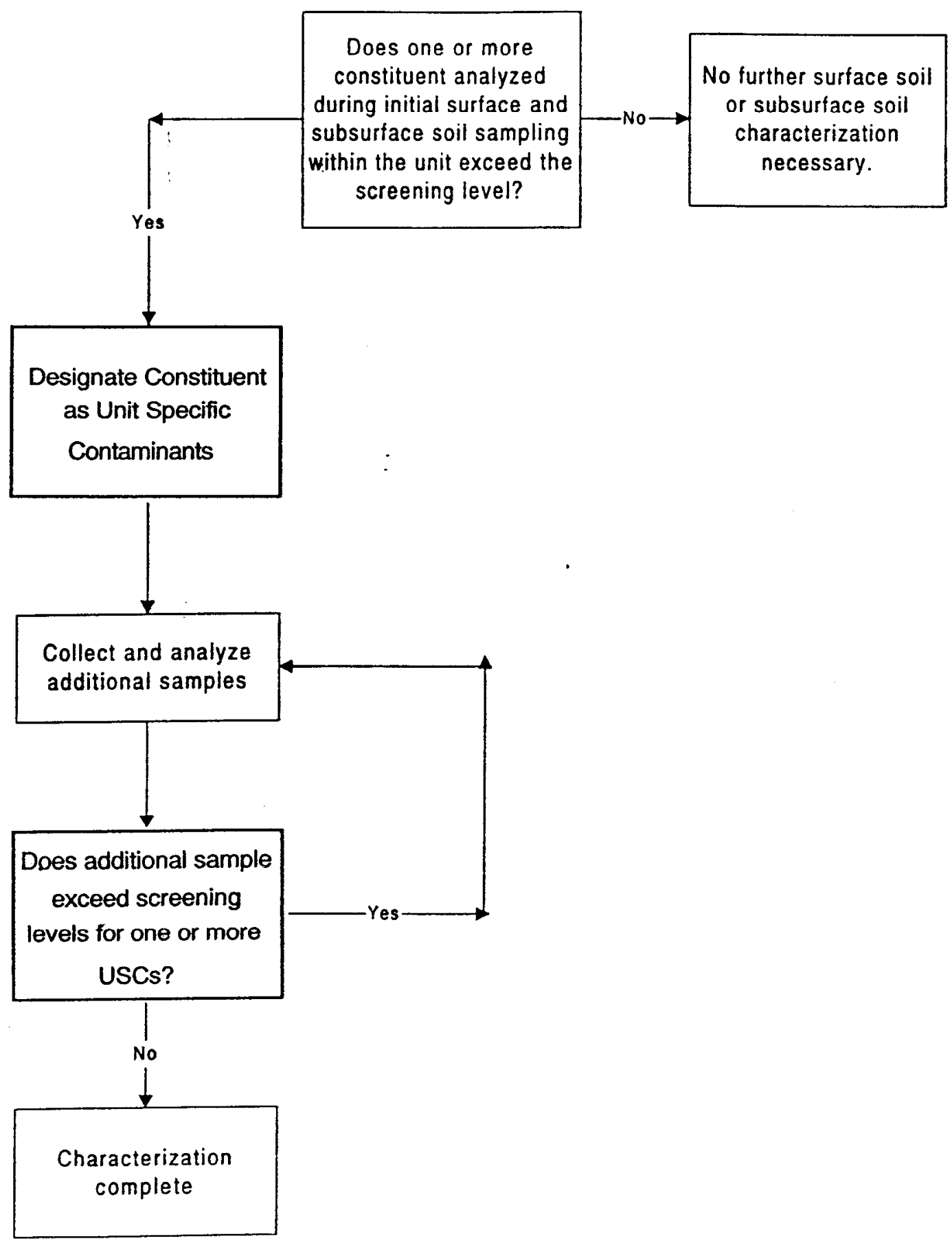




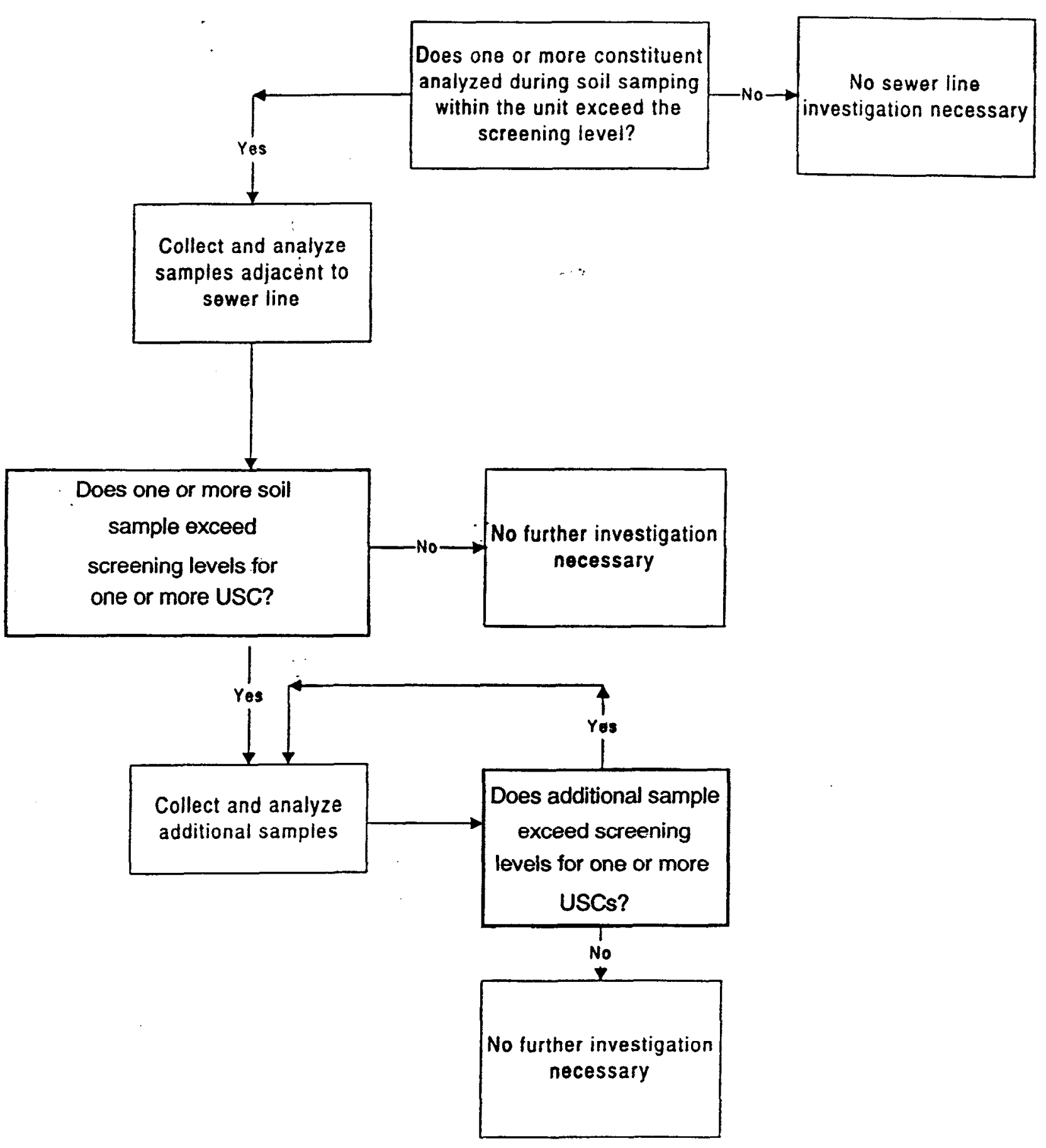




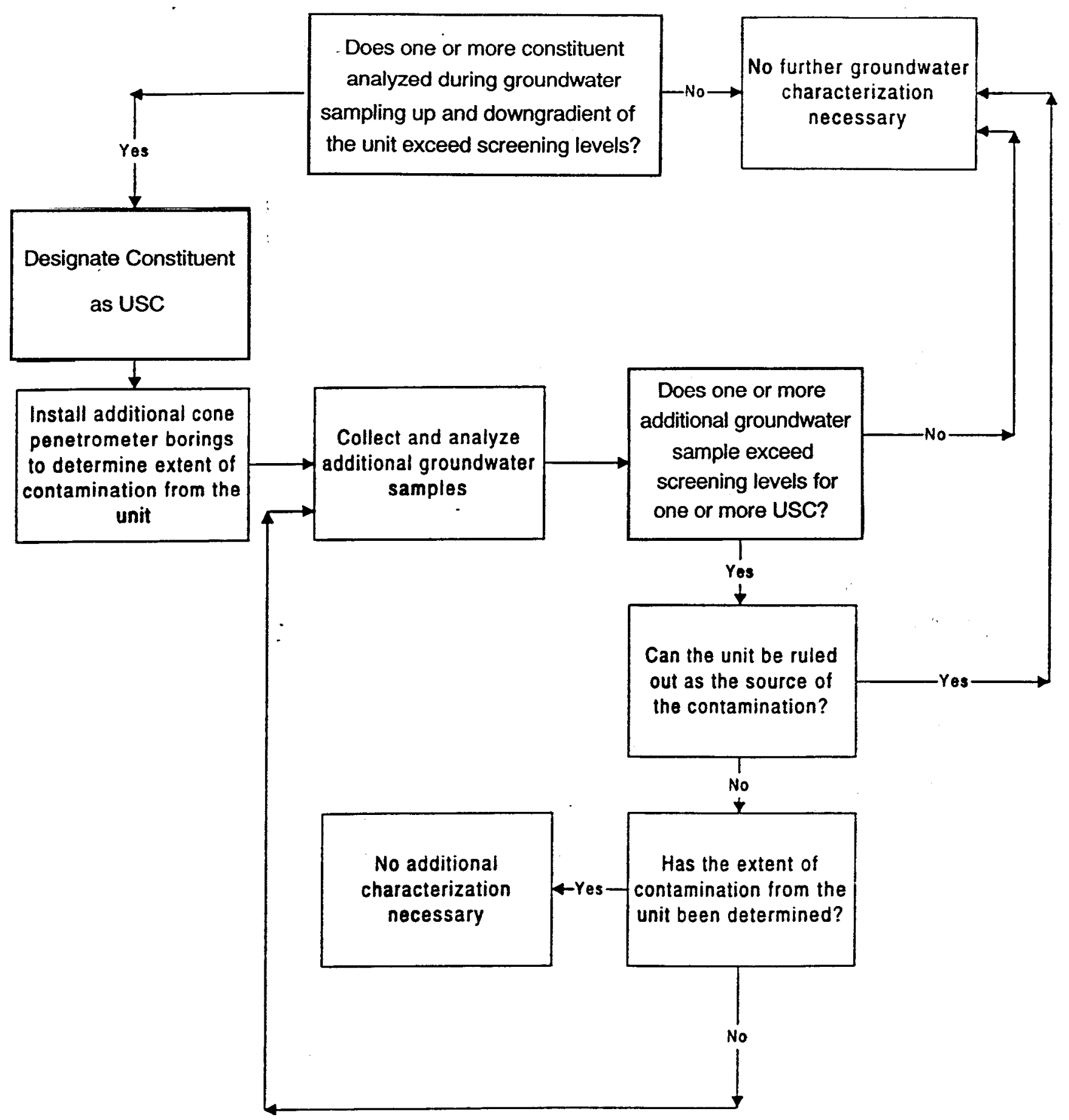




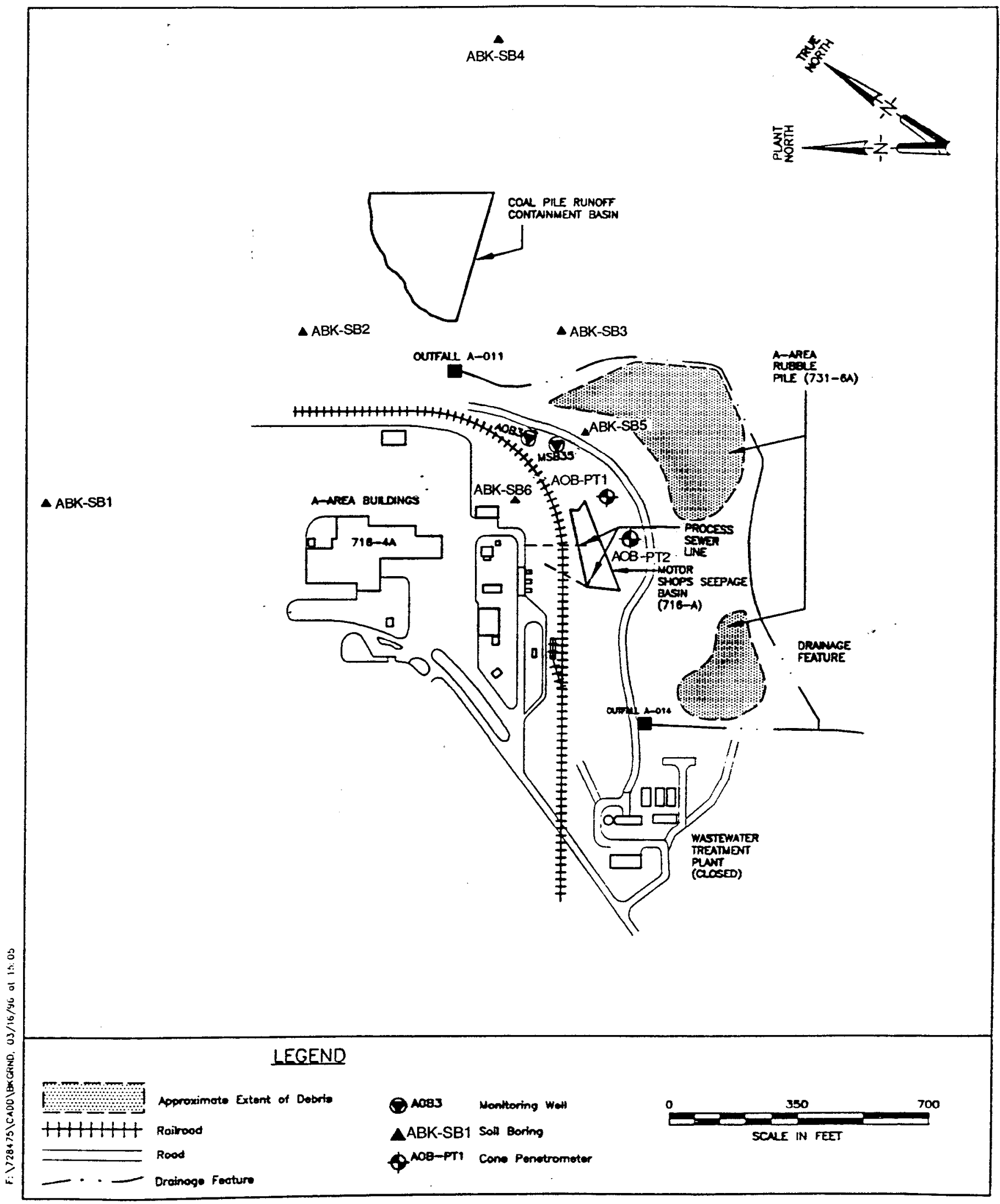

Figure 4-4 MOTOR SHOPS SEEPAGE BASIN BACKGROUND CHARACTERIZATION LOCATIONS 


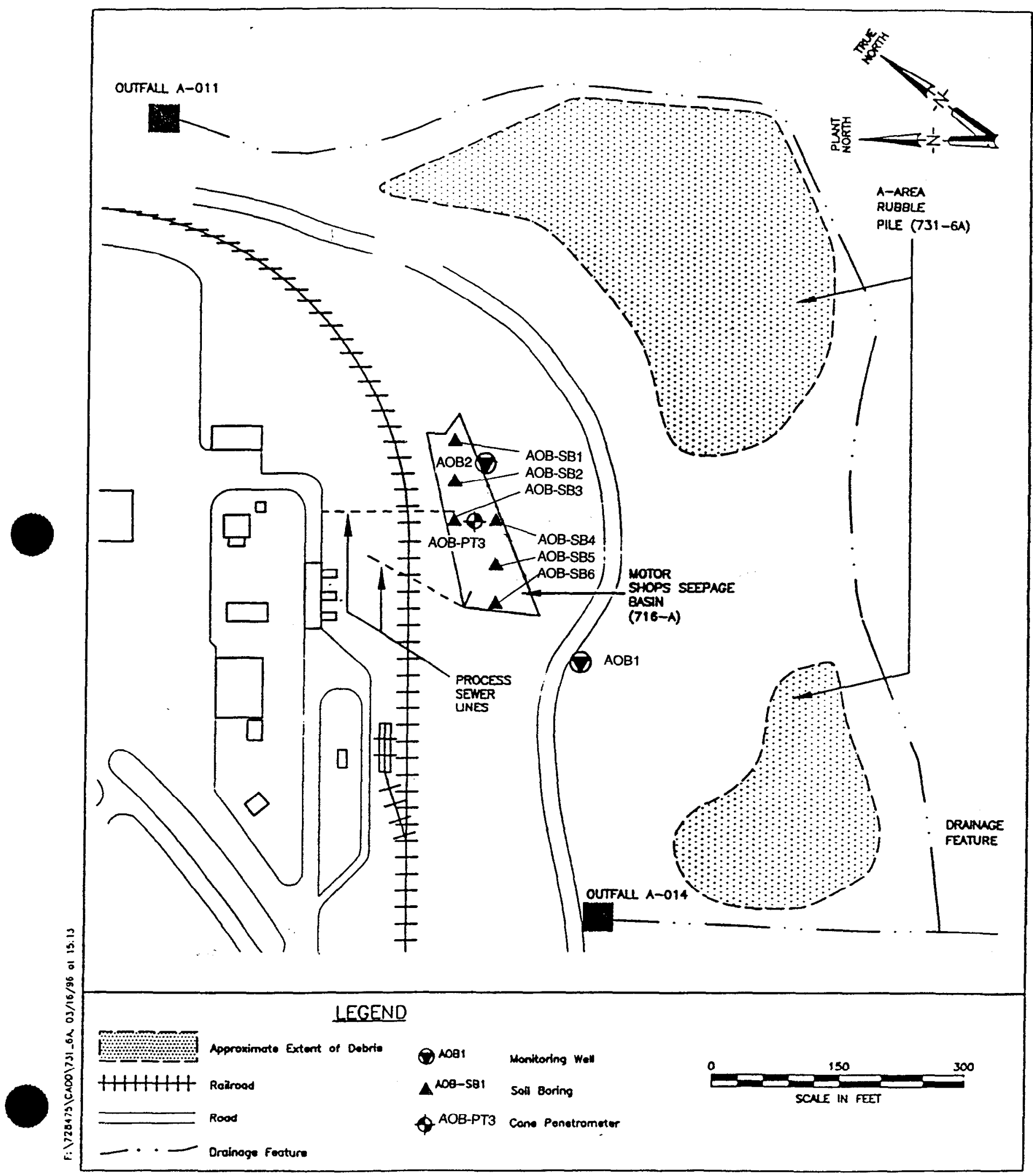

Figure 4-5 MOTOR SHOPS SEEPAGE BASIN SAMPLE LOCATIONS 


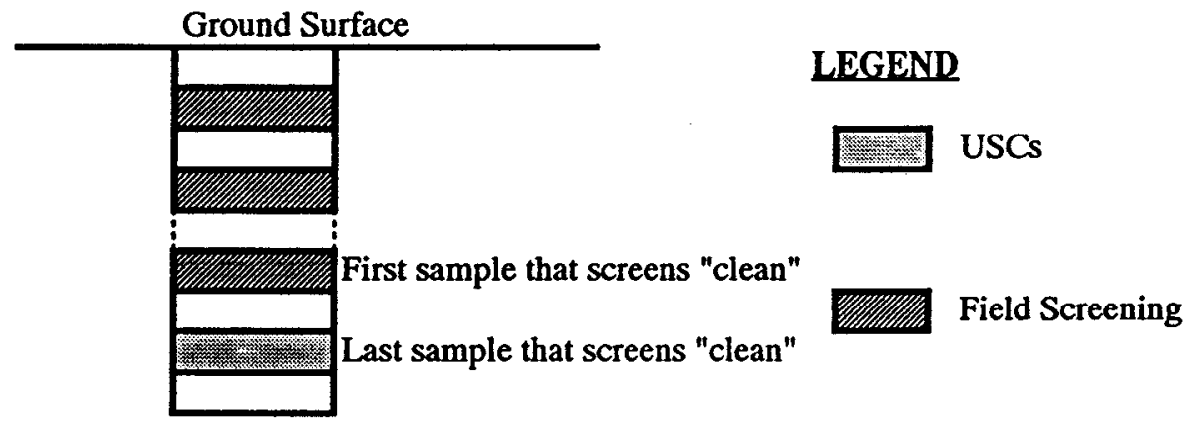

Vertical sampling will continue at 2 foot intervals until two consecutive samples screen below or at background levels or until groundwater is encountered. At this point, sampling will cease. Samples will be screened for USCs. The last sample that screens "clean" will also be sent for detailed analyses to confirm the absence of contamination. 


\section{CHAPTER 5 \\ SCHEDULE FOR RFI/RI ACTIVITIES AND DOCUMENT SUBMITTALS}

\subsection{INTRODUCTION}

This section includes the proposed schedule of field activities, and document and report submittals (Figure 5-1) for the Motor Shops Seepage Basin (MSSB). This schedule is subject to regulatory review timetables. Figure 5-1 illustrates the field start to record of decision schedule for the MSSB.

\subsection{PROJECTED SCHEDULE FOR FIELD ACTIVITIES}

As shown in Figure 5-1, sampling activities are scheduled to begin December 31, 1996. The schedule designates 9 months for field work. The estimated completion date for field activities is September 30, 1997.

\subsection{PROJECTED SCHEDULE FOR DOCUMENT AND REPORT SUBMITTALS}

The RFI/RI Report for the MSSB will be submitted after the field characterization activities have been completed. The final RFI/RI Report document will be submitted by September 5, 1998 with final approval scheduled for October 5, 1998. The final Feasibility Study/Corrective Measures Study will be submitted by February 7, 1997 with final approval scheduled for March 9, 1997. The review schedule for these documents is depicted in Figure 5-1. Figure 5-1 also describes the schedule for preparation and review of associated regulatory documents. 


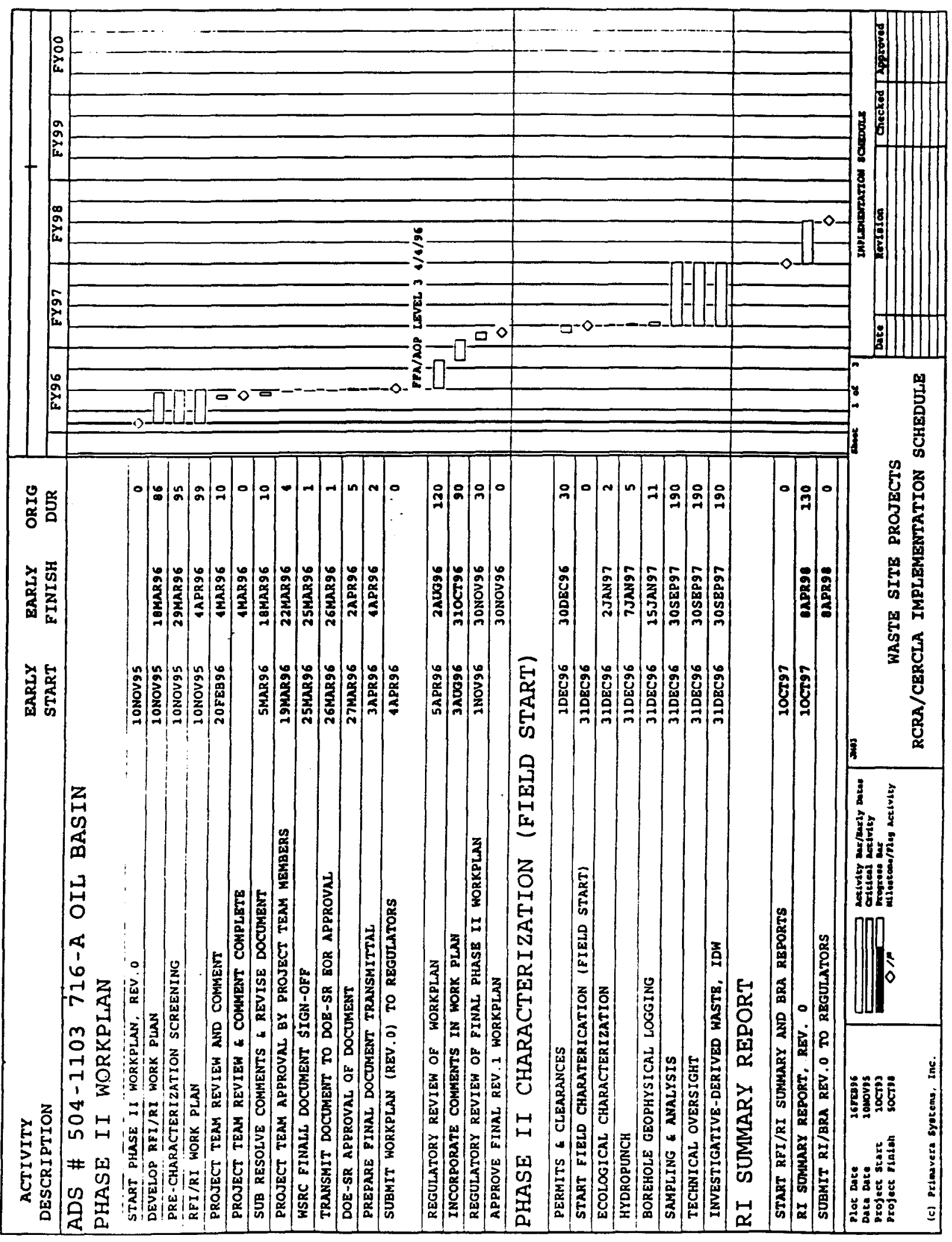

Figure 5-1 PROPOSED SCHEDULE OF FIELD ACTIVITIES AND DOCUMENT AND REPORT SUBMITTALS FOR 716-A MOTOR SHOPS SEEPAGE BASIN 


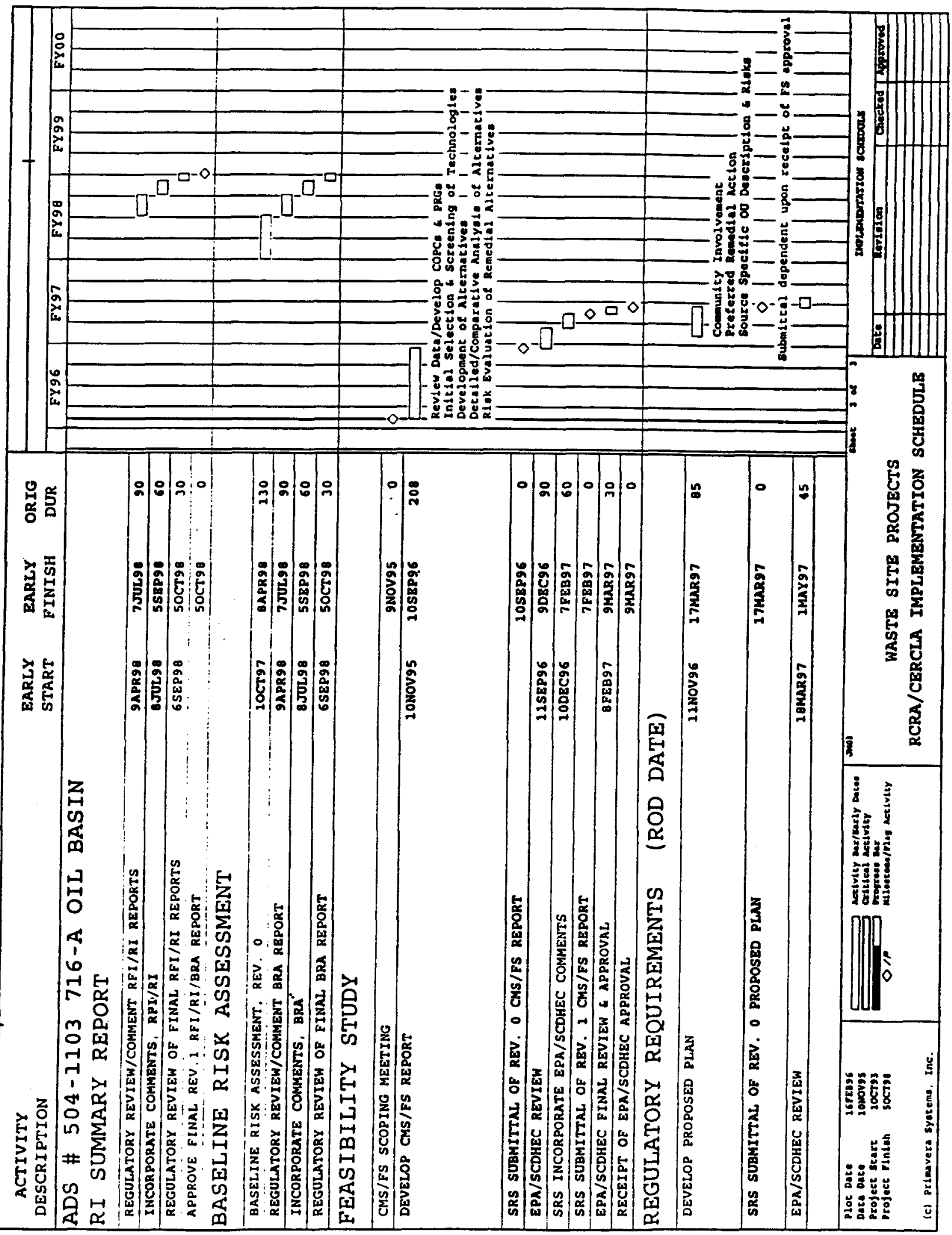

Figure 5-1 PROPOSED SCHEDULE OF FIELD ACTIVITIES AND DOCUMENT AND REPORT SUBMITTALS FOR 716-A MOTOR SHOPS SEEPAGE BASIN 


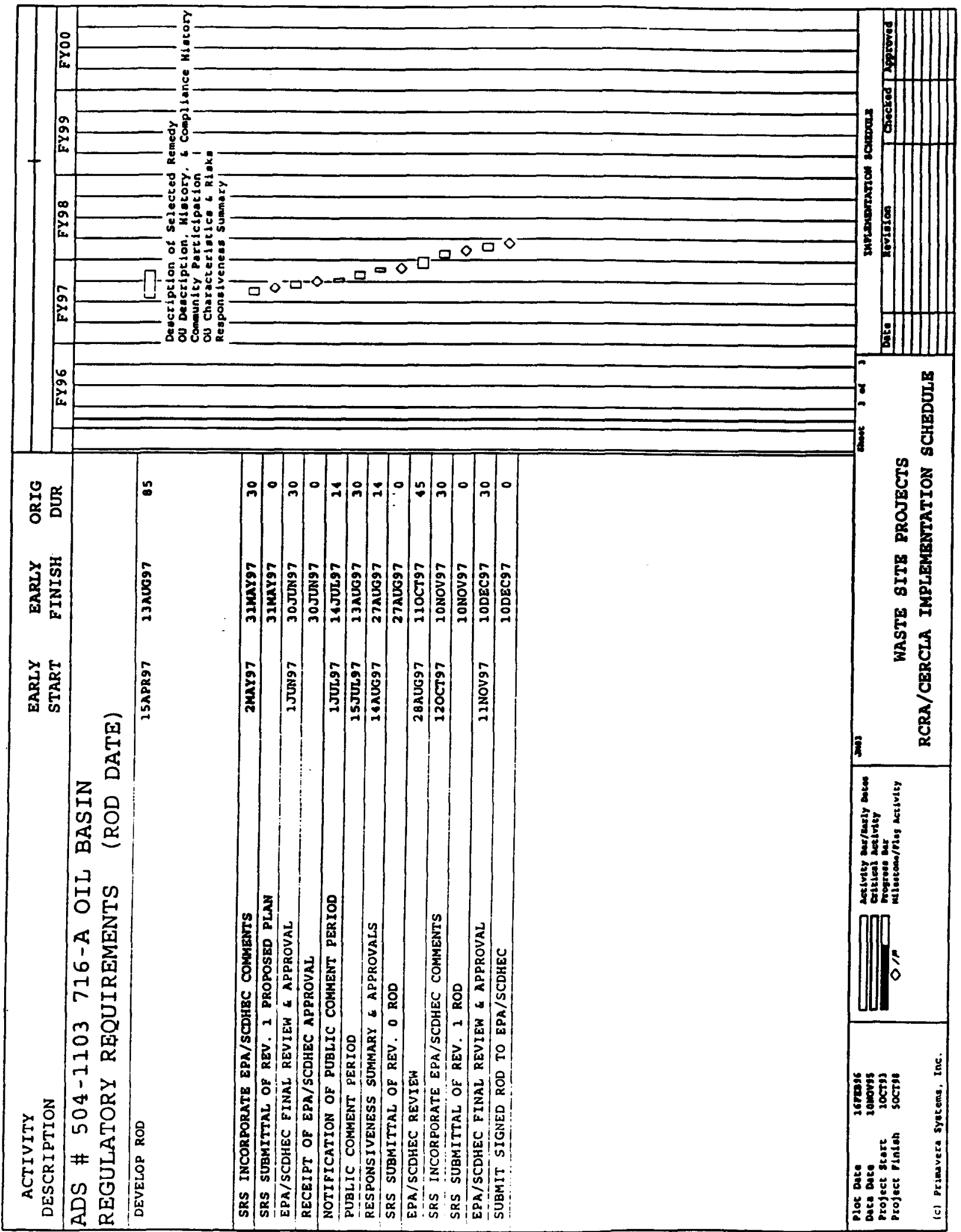

Figure 5-1 PROPOSED SCHEDULE OF FIELD ACTIVITIES AND DOCUMENT AND REPORT SUBMITTALS FOR 716-A MOTOR SHOPS SEEPAGE BASIN 


\section{CHAPTER 6 SAFETY, HEALTH AND EMERGENCY RESPONSE PLAN}

A site specific Health and Safety Plan (SSHASP) will be prepared in accordance with 29 CFR 1910.120 and approved prior to starting the field investigation. All personnel involved in the performance of the work shall be familiar with the provisions of the SSHASP. The SSHASP will be based upon the WSRC accepted SHERP, training, etc. that is in place for all field activities conducted at the Savannah River Site. 


\section{CHAPTER 7 QUALITY ASSURANCE/QUALITY CONTROL}

The Quality Assurance (QA) and Quality Control (QC) procedures to be used during investigations of the Motor Shops Seepage Basin at SRS are contained in WSRC Manual 1Q, Quality Assurance Manual (U) (WSRC, 1994); WSRC Manual 3Q5, Hydrogeologic Data Collection Procedures and Specifications (U) (WSRC, 1993b), and ESH-EMS950076, the Environmental Monitoring Section Environmental Geochemistry Group Program Overview (ESH-EMS, 1995). 


\section{CHAPTER 8}

\section{DATA MANAGEMENT PLAN}

Data management will be performed in accordance with the Environmental Monitoring Section Environmental Geochemistry Group Program Overview (ESH-EMS, May 1995). 


\section{CHAPTER 9 REFERENCES}

Aadland R.K. and H.W. Bledsoe, 1990, Classification of Hydrostratigraphic Units at the Savannah River Site, South Carolina, WSRC-RP-90-987, Westinghouse Savannah River Company, Savannah River Site, Aiken, South Carolina.

Aadland, R.K., A.D. Smits and P.A. Thayer, 1992, Geology and Hydrostratigraphy of the A/M Area, Savannah River Site (SRS), South Carolina (U), WSRC-RP-92632, Savannah River Technology Center, Westinghouse Savannah River Company, Savannah River Site, Aiken, South Carolina.

Bledsoe, H.W., R.K. Aadland, and K.S. Sargent, 1990, SRS Baseline Hydrogeologic Investigations Summary Report, WSRC-RP-90-1010, Savannah River Laboratory, Westinghouse Savannah River Company, Savannah River Site, Aiken, South Carolina.

Bouwer, H. and Rice, R.C., 1976, A Slug Test for Determining Hydraulic Conductivity of Unconfined Aquifers with Completed or Partially Penetrating Wells, WRR, June 1976.

Bouwer, H., 1989, The Bouwer and Rice Slug Test - An Update, Groundwater, May-June 1989.

Cahill, J. M., 1982, Hydrology of the Low-Level Radioactive Waste Burial Site and Vicinity near Barnwell, South Carolina, U.S. Geological Survey Open-File Report 82-863.

DOE (U.S. Department of Energy), 1994, Public Involvement, A Plan for the Savannah River Site, Savannah River Site, Aiken, South Carolina.

Fallaw, W.C. and Van Price, 1994, Stratigraphy of the Savannah River Site and Vicinity, Department of Geology, Furman University and Westinghouse Savannah River Company, Aiken, South Carolina.

Huber, L.A., W.F. Johnson, and H.W. Bledsoe, Environmental Information Document: Waste Oil Basins, 1987. DPST-85-701, E.I. du Pont de Nemours and Company, Savannah River Laboratory, Aiken, South Carolina. 
Lewis, S. E., and Aadland, R. K., 1994, Hydrogeologic Setting of A/M Area: Framework for Groundwater Transport $(U)$. Westinghouse Savannah River Company, Savannah River Site, Aiken, South Carolina.

Marine, I. W., and Bledsoe, H. W., 1984, M-Area Groundwater Investigation (Supplemental Technical Data Summary). Savannah River Laboratory Report DPSTD-84-112, Savannah River Plant, Aiken, South Carolina.

Neptune, M.D., Bar, P.S., and Michael, D.I., 1991, Planning for Data Collection: The Data Quality Objectives Process for Environmental Decisions, Draft Guidance. Washington, D.C.

Pirkle, Robert J. and D. J. Masdea, 1993. Soil Gas Investigations near the A Area Motor Shop Seepage Basin including Areas 716A and 731-A Savannah River Site Microseeps, University of Pittsburgh Applied Research Center.

U.S. EPA, 1989, Guidance for CERCLA Remedial Investigations, Office of Emergency and Remedial Response, U.S. Environmental Protection Agency, Washington, D.C.

U.S. EPA, April 1992, Guidance for Data Useability in Risk Assessment (Parts A and B), Office of Emergency and Remedial Response, U.S. Environmental Protection Agency, Washington, D.C.

U.S. EPA, 1994, Data Quality Objectives Process for Superfund, Office of Emergency and Remedial Response, U.S. Environmental Protection Agency, Washington, D.C.

U.S. EPA, May 1995, Drinking Water Regulations and Health Advisories, U.S. Environmental Protection Agency, Washington, D.C.

U.S. Soil Conservation Service (SCS), June 1990, Soil Survey of Savannah River Plant Area, Parts of Aiken, Barnwell, and Allendale Counties, South Carolina, United States Department of Agriculture.

WSRC, 1989, RCRA Facility Investigation Program Plan, WSRC-RP-89-994, Westinghouse Savannah River Company, Aiken, Savannah River Site, South Carolina.

WSRC, 1990, RCRA Facility Investigation/Remedial Investigation Plan for the 716-A Motor Shop Seepage Basin, WSRC-RP-90-581, Westinghouse Savannah River Company, Savannah River Site, Aiken, South Carolina.

WSRC, 1991, RCRA Facility Investigation Remedial Investigation for the A-Area Rubble Pile (731-6A), WSRC-RP-91-594 Westinghouse Savannah River Company, Savannah River Site, Aiken, South Carolina. 
WSRC, 1993a, RCRA Facility Investigation/Remedial Investigation Program Plan, WSRC-RP-89-994, Rev. 1, Westinghouse Savannah River Company, Savannah River Site, Aiken, South Carolina.

WSRC, 1993b, WSRC Hydrogeologic Data Collection Procedures and Specifications, Manual 3Q5, Westinghouse Savannah River Company, Savannah River Site, Aiken, South Carolina.

WSRC, 1994a, Westinghouse Savannah River Company Quality Assurance Manual, WSRC 1Q, Westinghouse Savannah River Company, Savannah River Site, Aiken, South Carolina.

WSRC, 1994b, Westinghouse Savannah River Company Investigative Derived Waste Management Plan, WSRC RP-94-1227, Westinghouse Savannah River Company, Savannah River Site, Aiken, South Carolina.

WSRC, 1995a, Environmental Monitoring Section Environmental Geochemistry Group Program Overview, ESH-EMS-950076, Westinghouse Savannah River Company, Savannah River Site, Aiken, South Carolina.

WSRC, 1995b, Savannah River Site Environmental Report for 1994, WSRC-TR-95-075, Westinghouse Savannah River Company, Savannah River Site, Aiken, South Carolina.

WSRC, 1995c, Hydrogeologic Framework for the Metallurgical Laboratory Basin Area $(U)$, WSRC RP-95-54, Westinghouse Savannah River Company, Savannah River Site, Aiken, South Carolina. 


\section{RFI SITE LITERATURE REVIEW CHECKLIST}

INTRODUCTION: GENERAL SITE DATA AND INFORMATION

\section{A. Site Identification}

1. RFI Site Name: 716-A Motor Shop Seepage Basin

2. RFI Site Locationl: Blda. No. 904-101G, Coordinates (See EID, D. 3)

B. General information (Common To All Media Investigations)

1. General Waste Characteristics: Wastes from 716-A Motor Shop oil/water Separator

a. Known Nonhazardous Waste Managed at the Site: Soapy water, etc.

b. Known Hazardous Waste Managed at the Site: Engine 0il, grease, kerosene, ethylene glycol, etc.

c. Hazardous Classification (e.g., flammable, corrosive): Toxic. Flammable, Dossibly corrosive

d. Quantity of Each Waste Managed at the Site: Unknown

e. Chemical Composition of Each Waste:

2. General RFI Unit/Disposal Area Characteristics:

a. Type of RFI Unit (from Section 4.2.2): Surface Impoundment (Seepage Basin)

b. Operational Period: $1977-1983$

c. Operational Capacity (Surface Area and/or Volume): Approximately $43,000 \mathrm{cu}$. ft. $(322,000 \mathrm{gal})$

d. Site Dimensions at Closure or Discontinued Use: $63.1 \mathrm{~m} \times 10.7 \mathrm{~m} \times 2 \mathrm{~m}$ deep

e. Description of Site Design Features: Seepage Basin with $2 m$ high berm on 3 sides, high side with railroad track on 4th side

f. Description of Operational History Detailing All Problems: Motor Shop wash water and waste passed through oil skimmer before discharged to basin.

9. Known Spills, Leaks, Odors, or Rupture Resulting in Waste Release:

Seepage from basin

1 Building number and SRP coordinates shall be used to identify the I:7284759510J39APP-A-1.WW2 ite location. 
h. Method Used to Close Unit (if applicable): Not Closed, but drain line from Motor Shop capped in 1983

3. General Geological Properties:
a. Detailed Contour Map Available? Yes $I^{\prime \prime}=100 \mathrm{ft}$. Reproduction Date: $4-21-88$
b. Depth to Water Table: 1st Quarter 1988: 101-105 feet
c. Distinction of Underlying Strata: EID, D. 14 Further characterized in Fall, 1988.
d. Classification of Surface and Subsurface Soils: Conducted in Fall 1988.

4. General Environmental Setting:
a. Average Temperature (Annual ${ }^{2}$ ): $70^{\circ} \mathrm{F}$
b. Average Precipitation (Annual ${ }^{2}$ ): 43 inches

5. Proximate Natural or Manmade Features (also list approximate distance from RFI site):
a. Ridges, Hills: None nearby. Pine forest adjacent
b. Valleys, Ravines: None nearby.
c. Surface Water Bodies: Tims Branch: 0.75 mile to East

d. Buildings: $1 / 4$ to $1 / 2$ mile to major $A / M$ facilities
e. Hard-Surfaced or Heavily-Trafficked Roads: 500 feet to road; Railroad track upgradient adjacent to bas in

6. Previous Sampling or Monitoring Data:
a. Date or Time Period of Sampling/Monitoring: 1984 to date
b. Source of Data (e.g., list specific EID): EID: Waste 0il Basins, OPST $-85-701$
c. Medium (Media) Sampled (e.g., ground water, soil): Ground Water. surface water in basin
d. Results of Sampling: Basin water: see EID. D. 36-37. Ground Water: Chlorinated hydrocarbons from other M-Area Sources.


I. SOILS SAMPLING CONSIDERATIONS

A. Waste Characteristics ETHYLENE GLYCOL

1. Specific Waste Information * (complete for each specific waste):

a. Physical State of Waste During Operational Period: Liquid

b. General Chemical class (e.g., acid, base, solvent): Alcohol (alycol)

c. Water Solubility: Sol, in water, alcohol, acetone

d. Molecular Weight: 62.07

e. Density: $1.12\left(020^{\circ} \mathrm{C}\right)$

f. Viscosity: Sliahtly $(19.9 \mathrm{cD})$

g. Boiling Point: $197.2^{\circ} \mathrm{C}$

h. Waste pH: low - diol - weak acid

i. Vapor Pressure: $0.120 \mathrm{~mm} \mathrm{Ha} \mathrm{C} 20^{\circ} \mathrm{C}$

j. Cohesiveness of Waste: low

2. Potential Transport Processes of Waste Managed at Site $^{3}$ :

a. Biodegradation Potential: high

b. Photodegradation Potential: low

c. Hydrolysis Potential: low

d. Oxidation/Reduction Potential: high

e. Volatilization Potential: low

f. Absorption Potential: low (low TOC)

g. Dissolution Potential: high

3 For each transport process listed above, indicate the potential for occurrence: "high", "low", or "uncertain". Assessment will be based on key waste factors listed in Table 4-1, Section 4.2.1. 
1. SOILS SAMPLING CONSIDERATIONS

A. Waste Characteristics

\section{KEROSENE}

1. Specific Waste Information (complete for each specific waste):

a. Physical State of Waste During Operational Period: oily Liquid

b. General Chemical Class (e.g., acid, base, solvent): Petroleum hydrocarbon mixture

c. Water Solubility: Insoluble

d. Molecular Weight: Mixture of Tong-chain hydrocarbons

e. Density: 0.81

f. Viscosity: $1.35 \mathrm{cD}$ \& $25^{\circ} \mathrm{C}$ (dodecane)

g. Boiling Point: $180-300^{\circ} \mathrm{C}$

h. Waste $\mathrm{pH}$ : uncertain - moderate

i. Vapor Pressure: approx. $1 \mathrm{mmHg}$ \& $47.8^{\circ} \mathrm{C}$

j. Cohesiveness of Waste: Miscible w/other petro. sol.

2. Potential Transport Processes of Waste Managed at $\mathrm{Site}^{3}$ :

a. Biodegradation Potential: high

b. Photodegradation Potential: high

c. Hydrolysis Potential: low

d. Oxidation/Reduction Potential: aromatics

e. Volatilization Potential: high

f. Absorption Potential: low

g. Dissolution Potential: low

3 For each transport process listed above, indicate the potential for occurrence: "high", "low", or "uncertain". Assessment will be based on key waste factors listed in Table 4-1, Section 4.2.1. 
B. RFI Site Design and Operational History

1. Potential Waste Release Mechanisms (Based on RFI Site Type, Table 4-2):

a. Visible Release Mechanism(s): $\ldots$

b. Suspected Release Mechanism(s): Release from overtopping. seepage

C. Soil Properties and Environmental Setting

1. Specific Soil Properties: (In the general $A / M$ area)*

a. Effective Porosity: $0.024-0.13 \star \star$ (E) lenton and Upper "Tuscaloosa" formations)

b. Hydraulic Conductivity (Permeability): $1.58 \mathrm{~m} /$ day $^{\star}$ (Tuscaloosa)

c. Relative Conductivity: Not Available

d. Soil pH: Nat Available

* No specific tests within Motor Shop Seepage Basin

2. Environmental Setting:

a. Description of Vegetation: (See Site Reconn. Field Data Sheet)

b. Description of Fauna: (See Site Reconn. Field Data Sheet)

1I. GROUNDWATER SAMPLING CONSIDERATIONS

A. Waste Characteristics (See I.A. above)

B. RFI Site Design and Operational History (See I.B. above)

C. Soil Properties and Environmental Setting

1. Additional Soil Properties:

a. Hydraulic Gradients: Unknown - to be determined after two additional wells are installed

b. Groundwater Flow Directions: Apparently to west due to impact from M-Area extraction wells

c. Groundwater Flow Velocity: Calculated at approximately

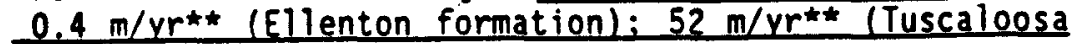
formation)

A-5

I:7284799510J3SAPP-A-1.YFN2 From EID: OPST-85-701, PP. 26-33 
111. SURFACE WATER/SEDIMENT SAMPLING CONSIDERATIONS

A. Waste Characteristics (See I.A. above)

B. RFI Site Design and Operational History

1. Design Controls (or absence of):

a. Description of Environmental Controls (e.g., dikes, contours, pumping operations): Berms around basin. extraction well pumping in M-Area HWMF

b. Description of Any Cracks, Flaws, Ruptures: None Visible

C. Environmental Factors

1. Surface Water Network Hydraul ics:

a. Type of Surface Water Feature le.g., drainage swale, stream, pond): Stream

b. Distance from RFI Unit: $1.220 \mathrm{~m}$ to east $\bullet$

c. Flow Rate/Velocity of Feature: _..

d. Description of Any Depositional Areas:

$--$

2. Climatology:

a. Temperature Stratification Potential: None

b. Freeze/Thaw Potential: None 
IV. AMBIENT AIR AND SOIL GAS SAMPLING CONSIDERATIONS

A. Waste Characteristics

1. Additional Waste Information (complete for each specific waste):

a. Physical State of Waste at Time of Disposal/Treatment: -...

b. Vapor Pressure (if applicable): $\cdots$

c. Water Solubility:

d. Molecular Weight:

e. Motsture Content: $-\infty$

f. Percent Volatile Material:

B. Site Desian and Operational History

1. Site Design: Zones of High Vapor Phase Release Potential:

a. Pipes, Outfalls, or Backfills Around Such Structures: None visible

b. Natural Animal Burrows or Habitat Openings: None visible

c. Sand or Gravel Lens fill: None

d. Cracks From Soil or Sludge Drying: Dried surface sludge cake during dry conditions.

e. Jointing in Bedrock:

2. Operation History:

a. Any Known Odor or Air Release Incidents:

b. Known "Worst-Case" Operational Practices Currently Being Followed (See Table 9-2, Section 9.2.2): None (inactive Site) 
C. Meteorological Factors and Environmental Setting

1. Additional Meteorological Parameters:

a. Description of Wind Speed and Direction:

b. Description of Wind Fluctuation/Stability:

c. Relative Humidity/Dew Point:

d. Atmospheric Pressure:

e. Evaporation Rate:

2. "Worst-Case" Meteorological Conditions:

a. Description of Known Occurrences During Past 5 Years: None

b. Frequency of Occurrence During Past 5 Years:

Checklist Completion Oate: Checklist Completion By:

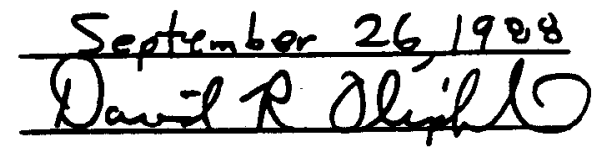




\section{SITE RECONNAISSANCE}

FIELD DATA SHEET

SAVANNAH RIVER PLANT, AIKEN, SOUTH CAROLINA

RFI Site Namel: $\begin{gathered}\text { 716-A Motor Shop } \\ \text { Seedage Basin }\end{gathered}$
RFI Site Location: A-Area
Building 904-1016

Completed By: David R. Oliphant

SRP Representative Name: Chris Leason

Date: August 9, 1988

\section{ENVIRONMENTAL SETTING}

Site Arrival Time: 1:45 P.m.

Heal th/Safety Recommendation Initiated: Yes No

1. Meteorological Conditions

a. Temperature 97 -f Sky Cover: sunny

b. Precipitation: none

c. Wind Conditions: light

2. Topographical/Bjological Descriotion

a. Description of corresponding natural features (hills, valleys, depressions, etc.): No outstanding natural features. Pine forest across the access road.

b. Description of corresponding surface water bodies (stream, river, lake, leachate): None nearby.

c. Description of corresponding vegetation (weeds/grass, underbrush, small/mature trees): Weeds and arass cover the basin berms and surrounding hill side. Some small seedlings on hill side above basin. Mature larger trees outside of basin to west of site.

d. Description of animal presence/habitat (tracks, nests, dens, etc.): A 6-inch long rat was visible in the dense underbrush. Several soecies of birds were periodically visible.

l Building number and SRP coordinates shall be used to identify the site location. 
3. Man-Made Features

a. Description of corresponding features (buildings, roads, powerlines, wells): Railroad track forms north boundary of site. Road $D$ runs within $1 / 3$ of mile of site. Groundwater well series MSB 35 is located within 50 yds east of site. Motor Shop work area is within 150 yds north.

II. SOURCE CHARACTERIZATION

\section{Site Area Characteristics}

a. Description of waste management activities ( 1 andfill, surface impoundment, etc.): Abandoned surface impoundment,

b. Estimation of waste management area size: See EID.

c. Construction of waste management area (earthen, liners, cement, above grade, etc.): Above grade seepage basin with 6-ft. high berms on 3 sides, Basin bottom slopes to elant west (away from influent end of basinl.

d. Is the site in current use/operation: No Conment:

\section{Waste Characteristics}

a. Description of any visible waste: No veqetation growing in bottom of basin. length of entire basin. Several old rotting timbers/railroad ties in basin bottom.

b. Quantity of waste (number of drums, pile size, \% S.I./basin filled): old timbers, plus, styrofoam which has blown into basin. 
III. WASTE RELEASE POTENTIAL

1. Io Soil/Groundwater/Surface Water

a. Description of waste run-off/leachate (soil discoloration, dead vegetation or no growth, erosion, etc.): Soil discoloration in middle of basin .. Nothing growing in basin center. Sparse grasses covering south area below basin. 0ld access driveway previously located in this area.

b. Estimate of impacted area (size of area, distance from the source, etc.): Soil discoloration area 10-15 ft. wide for length of basin.

2. To Atmosphere/Subsurface Gas

a. Description of gas release to atmosphere (odors, dead vegetation, visible odor, etc.): None Yisible.

b. Estimate of impacted area: None Visible.

IV. FINAL CHARACTERIZATION

1. Additional comments: 0ld influent pipe located, See attached sketch. Recommend that first sampling point be located at bottom of basin at influent point. Other 3 samoling locations at intervals down bas in length.

2. Follow-up questions: Need to confirm the location of a new monitoring well to the west of the basin.

3. Health/safety concerns: Need foot/leg orotection while covering working in basin (for sludge (dried) and for snakes). Need to cut back weeds in basin and hills side plus 3-4 access/egress points. Also need care when drilling into sludge, Use explosimeter.

4. Site Departure Time: $2: 30$ D.m.

\section{v. PHOTOGRAPHS}

1. Photographs Taken: No

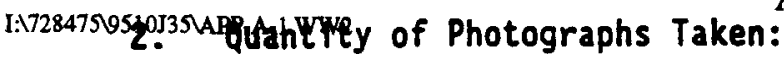


Data Quality Objectives Worksheet

\begin{tabular}{|c|c|c|c|c|c|c|c|}
\hline Source/Media & $\begin{array}{c}\text { Release } \\
\text { Mechanism }\end{array}$ & $\begin{array}{l}\text { Exposure } \\
\text { Route }\end{array}$ & $\begin{array}{l}\text { Data Needs } \\
\text { and DQOs }\end{array}$ & $\begin{array}{c}\text { Characterization } \\
\text { Activity }\end{array}$ & Parameters & . Uncertainty & $\begin{array}{l}\text { Early } \\
\text { Interim } \\
\text { Action }\end{array}$ \\
\hline Wosternater & $\%$ & \% & \% & \% & \% & $\%$ & X \\
\hline $\begin{array}{c}\text { Primary } \\
\text { Source/Media }\end{array}$ & $\begin{array}{c}\text { Release } \\
\text { Mechanism }\end{array}$ & $\begin{array}{c}\text { Exposure } \\
\text { Route }\end{array}$ & $\begin{array}{l}\text { Data Needs } \\
\text { and DQOs }\end{array}$ & $\begin{array}{c}\text { Characterization } \\
\text { Activity }\end{array}$ & Parameters & Uncertainty & $\begin{array}{l}\text { Early } \\
\text { Interim } \\
\text { Action }\end{array}$ \\
\hline \multirow[t]{2}{*}{ 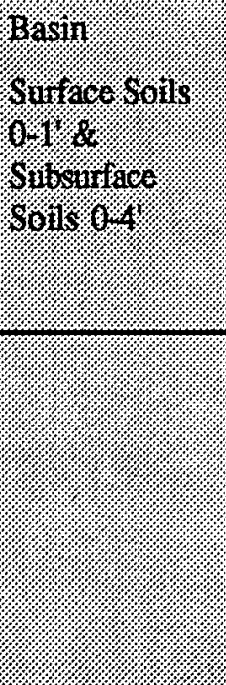 } & 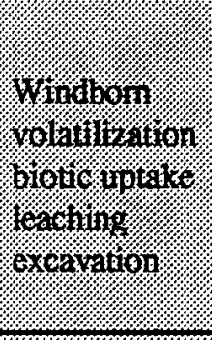 & monosinon & 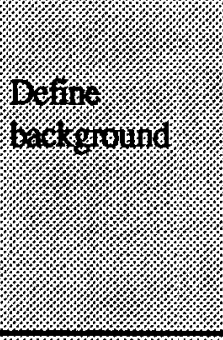 & 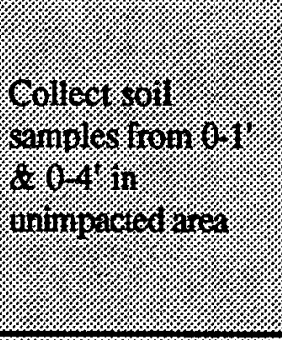 & 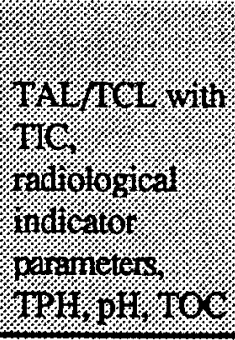 & 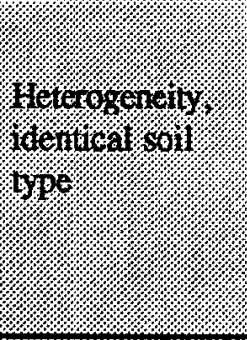 & 40 \\
\hline & & & 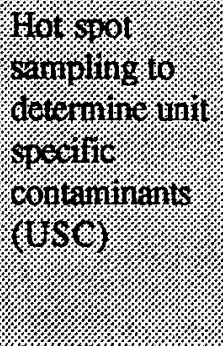 & 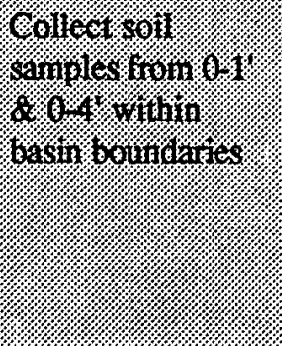 & 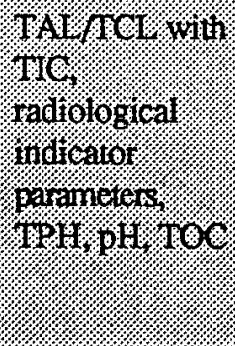 & 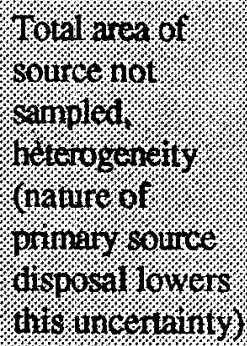 & No \\
\hline
\end{tabular}

Phase 1 activities shaded. 


\section{Data Quality Objectives Worksheet (Continued)}

\begin{tabular}{|c|c|c|c|c|c|c|c|}
\hline $\begin{array}{c}\text { Primary } \\
\text { Source/Media }\end{array}$ & $\begin{array}{c}\text { Release } \\
\text { Mechanism }\end{array}$ & $\begin{array}{c}\text { Exposure } \\
\text { Route }\end{array}$ & $\begin{array}{l}\text { Data Needs } \\
\text { and DQOs }\end{array}$ & $\begin{array}{c}\text { Characterization } \\
\text { Activity }\end{array}$ & Parameters & Uncertainty & $\begin{array}{l}\text { Early } \\
\text { Interim } \\
\text { Action }\end{array}$ \\
\hline \multicolumn{8}{|l|}{ Basin } \\
\hline \multirow[t]{3}{*}{$\begin{array}{l}\text { Surface Soils } \\
0-1^{\prime} \& \\
\text { Subsurface } \\
\text { Soils } 0-4^{\prime} \\
\text { (Cont'd) }\end{array}$} & & & $\begin{array}{l}\text { Determine } \\
\text { horizontal } \\
\text { extent of USC } \\
\text { ( }>2 X \\
\text { background, } \\
\text { risk based } \\
\text { concentrations } \\
\text { (RBC), and } \\
\text { action levels) }\end{array}$ & $\begin{array}{l}\text { Collect unbiased } \\
\text { soil samples from } \\
0-1 \text { ' \& } 0-4 \text { ' } \\
\text { adjacent to basin } \\
\text { boundaries if any } \\
\text { basin samples are } \\
\text { positive }\end{array}$ & USC & $\begin{array}{l}\text { Total area of } \\
\text { source not } \\
\text { sampled, } \\
\text { heterogeneity }\end{array}$ & No \\
\hline & & & 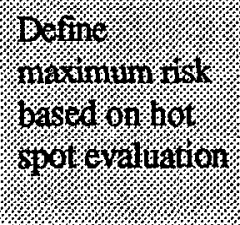 & 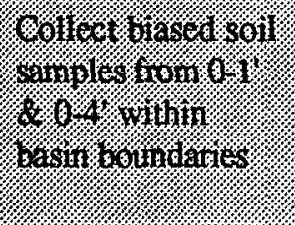 & 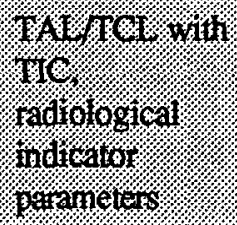 & 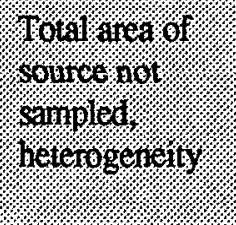 & 10. \\
\hline & & & $\begin{array}{l}\text { Define risk } \\
\text { potential based } \\
\text { on exposure } \\
\text { unit }\end{array}$ & $\begin{array}{l}\text { Unbiased sampling } \\
\text { adjacent to basin as } \\
\text { basin samples } \\
\text { dictate }\end{array}$ & USC & $\begin{array}{l}\text { Heterogeneity, } \\
\text { adequacy of } \\
\text { sample spacing }\end{array}$ & No \\
\hline
\end{tabular}

Phase 1 activities shaded. 


\section{Data Quality Objectives Worksheet (Continued)}

\begin{tabular}{|c|c|c|c|c|c|c|c|}
\hline $\begin{array}{c}\text { Primary } \\
\text { Source/Media }\end{array}$ & $\begin{array}{c}\text { Release } \\
\text { Mechanism }\end{array}$ & $\begin{array}{c}\text { Exposure } \\
\text { Route }\end{array}$ & $\begin{array}{l}\text { Data Needs } \\
\text { and DQOs }\end{array}$ & $\begin{array}{c}\text { Characterization } \\
\text { Activity }\end{array}$ & Parameters & Uncertainty & $\begin{array}{l}\text { Early } \\
\text { Interim } \\
\text { Action }\end{array}$ \\
\hline \multicolumn{8}{|l|}{ Basin } \\
\hline $\begin{array}{l}\text { Surface Soils } \\
0-1^{\prime} \& \\
\text { Subsurface } \\
\text { Soils } 0-4^{\prime} \\
\text { (Cont'd) }\end{array}$ & & & $\begin{array}{l}\text { Geotech and } \\
\text { geophysical } \\
\text { parameters for } \\
\text { fate \& transport } \\
\text { (or leachability) } \\
\text { analysis }\end{array}$ & $\begin{array}{l}\text { Collect soil } \\
\text { samples from } 0-1 \text { ' } \\
\& 0-4 \text { ' within and } \\
\text { adjacent to basin } \\
\text { boundaries }\end{array}$ & $\begin{array}{l}\text { Permeability, } \\
\text { grain size, } \\
\text { moisture } \\
\text { content, pH, } \\
\text { bulk density, } \\
\text { porosity } \\
\text { lithologic } \\
\text { description, } \\
\text { TOC }\end{array}$ & $\begin{array}{c}\text { Heterogeneity } \\
\\
\vdots\end{array}$ & No \\
\hline \multicolumn{8}{|l|}{ Basin } \\
\hline $\begin{array}{l}\text { Subsurface } \\
\text { Soils }>4^{\prime}\end{array}$ & Leaching & $\begin{array}{l}\text { (To } \\
\text { groundwater) }\end{array}$ & $\begin{array}{l}\text { Determine } \\
\text { vertical extent } \\
\text { of } \\
\text { contamination > } \\
2 \mathrm{X} \text { background } \\
\text { within basin } \\
\text { boundaries and } \\
\text { adjacent }\end{array}$ & $\begin{array}{l}\text { Collect soil } \\
\text { samples }>4^{\prime} \text { as }<4^{\prime} \\
\text { samples dictate }\end{array}$ & $\begin{array}{l}\text { Site specific } \\
\text { contaminants as } \\
\text { determined by } \\
\text { Phase I }\end{array}$ & $\begin{array}{l}\text { Total area of } \\
\text { source not } \\
\text { sampled }\end{array}$ & No \\
\hline
\end{tabular}

Phase 1 activities shaded. 
Data Quality Objectives Worksheet (Continued)

\begin{tabular}{|c|c|c|c|c|c|c|c|}
\hline $\begin{array}{c}\text { Primary } \\
\text { Source/Media }\end{array}$ & $\begin{array}{c}\text { Release } \\
\text { Mechanism }\end{array}$ & $\underset{\text { Route }}{\text { Exposure }}$ & $\begin{array}{l}\text { Data Needs } \\
\text { and DQOs }\end{array}$ & $\begin{array}{c}\text { Characterization } \\
\text { Activity }\end{array}$ & Parameters & Uncertainty & $\begin{array}{l}\text { Early } \\
\text { Interim } \\
\text { Action }\end{array}$ \\
\hline $\begin{array}{l}\text { Basin } \\
\text { Subsurface } \\
\text { Soils }>4^{\prime} \\
\text { (Cont'd) }\end{array}$ & & & $\begin{array}{l}\text { Determine fate } \\
\text { and transport of } \\
\text { contaminants } \\
\text { through } \\
\text { subsurface soils }\end{array}$ & $\begin{array}{l}\text { Collect soil } \\
\text { samples }>4^{\prime} \text { as }<4^{\prime} \\
\text { samples dictate } \\
\text { Obtain geologic } \\
\text { and hydrogeologic } \\
\text { data to predict } \\
\text { leachability }\end{array}$ & $\begin{array}{l}\text { Site specific } \\
\text { contaminants as } \\
\text { determined by } \\
\text { Phase I } \\
\text { Lithology } \\
\text { description, } \\
\text { permeability, } \\
\text { grain size }\end{array}$ & $\begin{array}{l}\text { Total area of } \\
\text { source not } \\
\text { sampled, } \\
\text { heterogeneity }\end{array}$ & No \\
\hline $\begin{array}{l}\text { Process Sewer } \\
\text { Line Soils }\end{array}$ & $\begin{array}{l}\text { Windborn } \\
\text { volatilization } \\
\text { biotic uptake } \\
\text { runoff } \\
\text { leaching } \\
\text { excavation }\end{array}$ & $\begin{array}{l}\text { Ingestion } \\
\text { inhalation } \\
\text { dermal contact }\end{array}$ & $\begin{array}{l}\text { Determine } \\
\text { impact to the } \\
\text { environment as } \\
\text { a result of the } \\
\text { process sewer } \\
\text { line } \\
\text { Define risk } \\
\text { impact }\end{array}$ & $\begin{array}{l}\text { Collect soil } \\
\text { samples adjacent } \\
\text { (3' laterally - or } \\
\text { less) to process } \\
\text { sewer line if any } \\
\text { basin samples are } \\
\text { positive }\end{array}$ & USC & $\begin{array}{l}\text { Heterogeneity, } \\
\text { sample spacing }\end{array}$ & No \\
\hline
\end{tabular}

Phase 1 activities shaded. 


\section{Data Quality Objectives Worksheet (Continued)}

\begin{tabular}{|c|c|c|c|c|c|c|c|}
\hline $\begin{array}{c}\text { Primary } \\
\text { Source/Media }\end{array}$ & $\begin{array}{c}\text { Release } \\
\text { Mechanism }\end{array}$ & $\begin{array}{c}\text { Exposure } \\
\text { Route }\end{array}$ & $\begin{array}{l}\text { Data Needs } \\
\text { and DQOs }\end{array}$ & $\begin{array}{c}\text { Characterization } \\
\text { Activity }\end{array}$ & Parameters & Uncertainty & $\begin{array}{l}\text { Early } \\
\text { Interim } \\
\text { Action }\end{array}$ \\
\hline $\begin{array}{l}\text { Process Sewer } \\
\text { Line Soils } \\
\text { (Cont'd) }\end{array}$ & & & $\begin{array}{l}\text { Define vertical } \\
\text { and horizontal } \\
\text { extent of USC }\end{array}$ & $\begin{array}{l}\text { Collect soil } \\
\text { samples laterally } \\
\text { and vertically as } \\
\text { initial process } \\
\text { sewer line samples } \\
\text { dictate }\end{array}$ & USC & $\begin{array}{l}\text { Heterogeneity, } \\
\text { sample spacing }\end{array}$ & No \\
\hline
\end{tabular}

\begin{tabular}{|c|c|c|c|c|c|c|c|}
\hline $\begin{array}{c}\text { Secondary } \\
\text { Source/Media }\end{array}$ & $\begin{array}{c}\text { Release } \\
\text { Mechanism }\end{array}$ & $\begin{array}{l}\text { Exposure } \\
\text { Route }\end{array}$ & $\begin{array}{l}\text { Data Needs } \\
\text { and DQOs }\end{array}$ & $\begin{array}{c}\text { Characterization } \\
\text { Activity }\end{array}$ & Parameters & Uncertainty & $\begin{array}{l}\text { Early } \\
\text { Interim } \\
\text { Action }\end{array}$ \\
\hline \multirow[t]{2}{*}{ Groundwater } & NA & $\begin{array}{l}\text { Ingestion } \\
\text { inhalation } \\
\text { dermal contact }\end{array}$ & $\begin{array}{l}\text { Groundwater } \\
\text { impacted by any } \\
\text { unit source }\end{array}$ & $\begin{array}{l}\text { Cone penetrometer } \\
\text { groundwater } \\
\text { samples up and } \\
\text { down gradient }\end{array}$ & USC & $\begin{array}{l}\text { Definitive data } \\
\text { source }\end{array}$ & No \\
\hline & & & $\begin{array}{l}\text { Groundwater } \\
\text { impacted by } \\
\text { other, non-unit } \\
\text { sources }\end{array}$ & $\begin{array}{l}\text { Cone penetrometer } \\
\text { groundwater } \\
\text { samples up and } \\
\text { down gradient }\end{array}$ & $\begin{array}{l}\text { USC and non- } \\
\text { unit potential } \\
\text { contaminants }\end{array}$ & $\begin{array}{l}\text { Definitive data } \\
\text { source, non-unit } \\
\text { characterization }\end{array}$ & No \\
\hline
\end{tabular}

Phase 1 activities shaded. 


\section{Data Quality Objectives Worksheet (Continued)}

\begin{tabular}{|c|c|c|c|c|c|c|c|}
\hline $\begin{array}{c}\text { Secondary } \\
\text { Source/Media }\end{array}$ & $\begin{array}{c}\text { Release } \\
\text { Mechanism }\end{array}$ & $\begin{array}{l}\text { Exposure } \\
\text { Route }\end{array}$ & $\begin{array}{l}\text { Data Needs } \\
\text { and DQOs }\end{array}$ & $\begin{array}{c}\text { Characterization } \\
\text { Activity }\end{array}$ & Parameters & Uncertainty & $\begin{array}{l}\text { Early } \\
\text { Interim } \\
\text { Action }\end{array}$ \\
\hline \multirow[t]{4}{*}{$\begin{array}{l}\text { Groundwater } \\
\text { (Cont'd) }\end{array}$} & & & Risk impact & $\begin{array}{l}\text { Well installations } \\
\text { based on cone } \\
\text { penetrometer } \\
\text { samples to collect } \\
\text { definitive samples }\end{array}$ & $\begin{array}{l}\text { USC and non- } \\
\text { unit potential } \\
\text { contaminants }\end{array}$ & $\begin{array}{l}\text { Complete well } \\
\text { development }\end{array}$ & No \\
\hline & & & $\begin{array}{l}\text { Groundwater } \\
\text { flow direction } \\
\text { and rate }\end{array}$ & $\begin{array}{l}\text { Cone penetrometer } \\
\text { and/or well } \\
\text { installation and } \\
\text { development }\end{array}$ & $\begin{array}{l}\text { Water } \\
\text { elevations and } \\
\text { hydraulic } \\
\text { conductivity }\end{array}$ & $\begin{array}{l}\text { Complete well } \\
\text { development } \\
\text { accuracy of slug } \\
\text { tests }\end{array}$ & No \\
\hline & & & & Slug tests & & & \\
\hline & & & $\begin{array}{l}\text { Determine } \\
\text { nature and } \\
\text { extent if } \\
\text { impacted } \\
\text { (define plume) }\end{array}$ & $\begin{array}{l}\text { Cone penetrometer } \\
\text { groundwater } \\
\text { samples up and } \\
\text { down gradient }\end{array}$ & $\begin{array}{l}\text { USC and non- } \\
\text { unit potential } \\
\text { contaminants }\end{array}$ & $\begin{array}{l}\text { Definitive data } \\
\text { source }\end{array}$ & No \\
\hline Biotic & Biotic uptake & Ingestion & $\begin{array}{l}\text { Ecological risk } \\
\text { assessment }\end{array}$ & $\begin{array}{l}\text { No new data to be } \\
\text { collected. Data } \\
\text { from abiotic media } \\
\text { will be modeled to } \\
\text { estimate biotic } \\
\text { concentrations. }\end{array}$ & NA & $\begin{array}{l}\text { Estimate versus } \\
\text { actual } \\
\text { concentrations. }\end{array}$ & No \\
\hline
\end{tabular}

Phase 1 activities shaded. 
RFI/RI Work Plan for the Motor Shops Seepage Basin
WSRC-RP-96-00111, Revision 0 March 1996

\section{APPENDIX A.4 SITE PHOTOS}




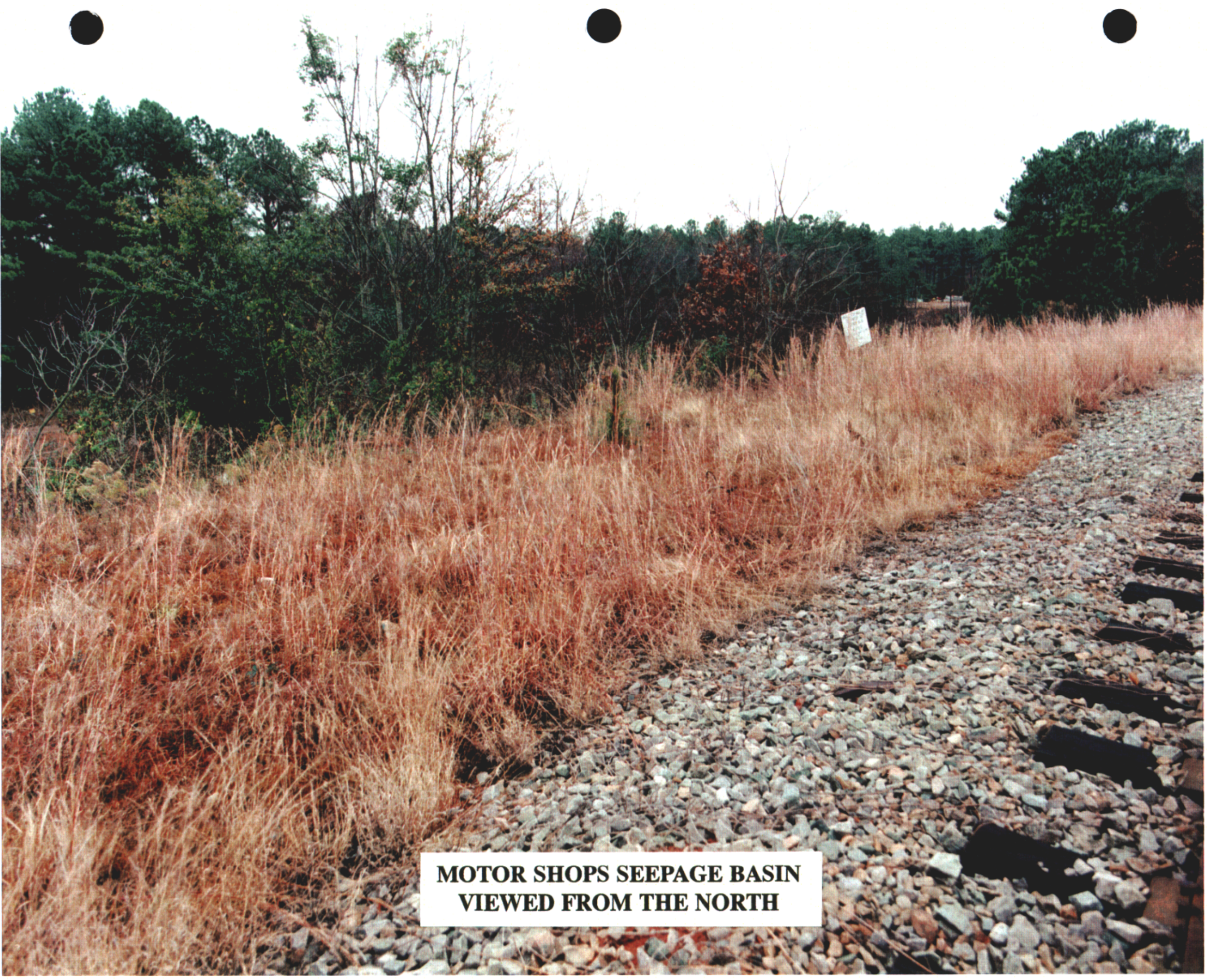




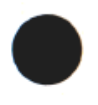

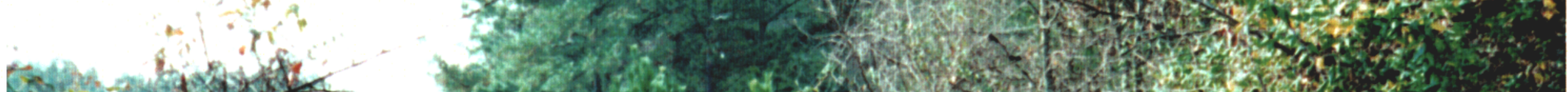

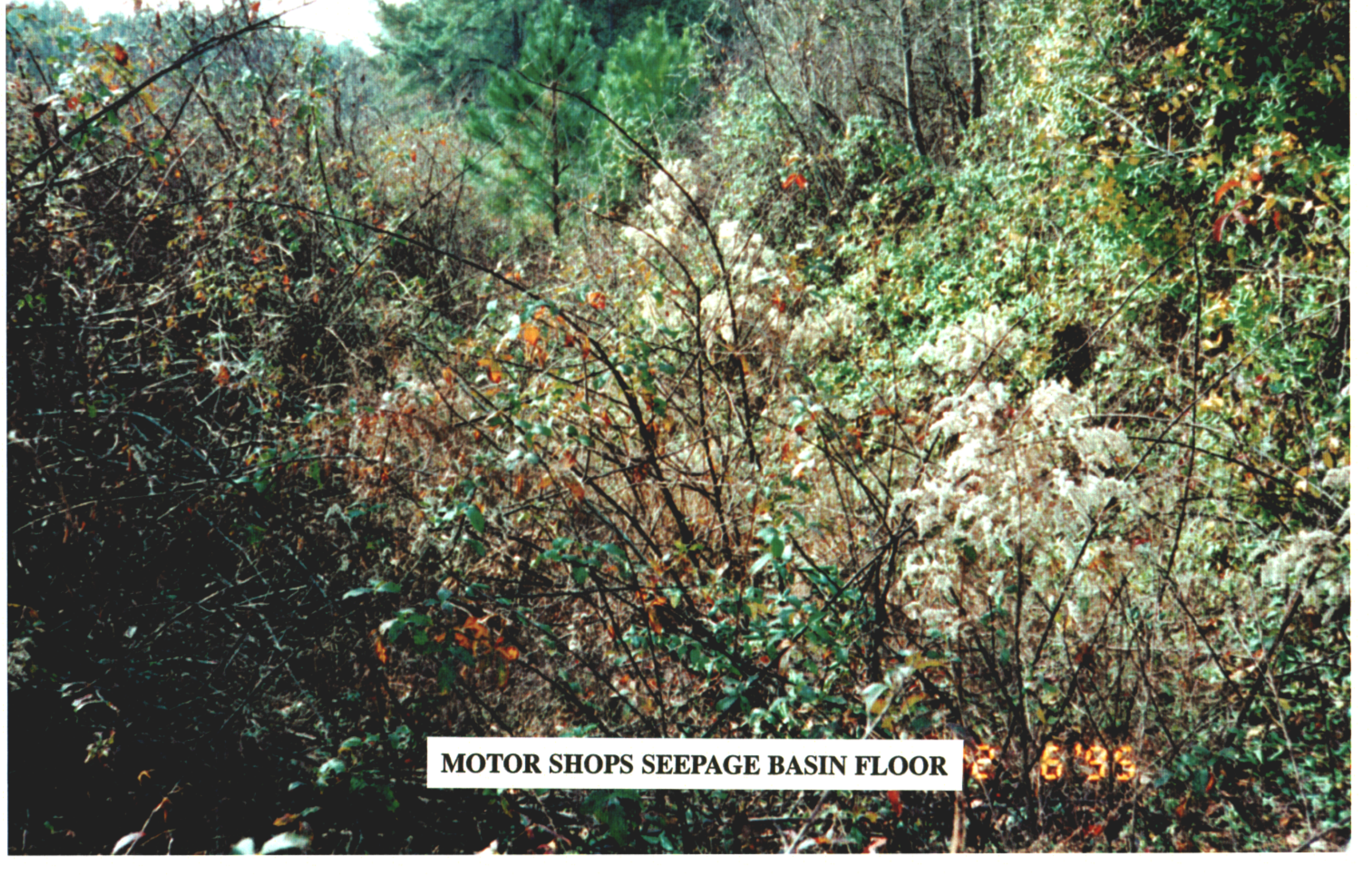




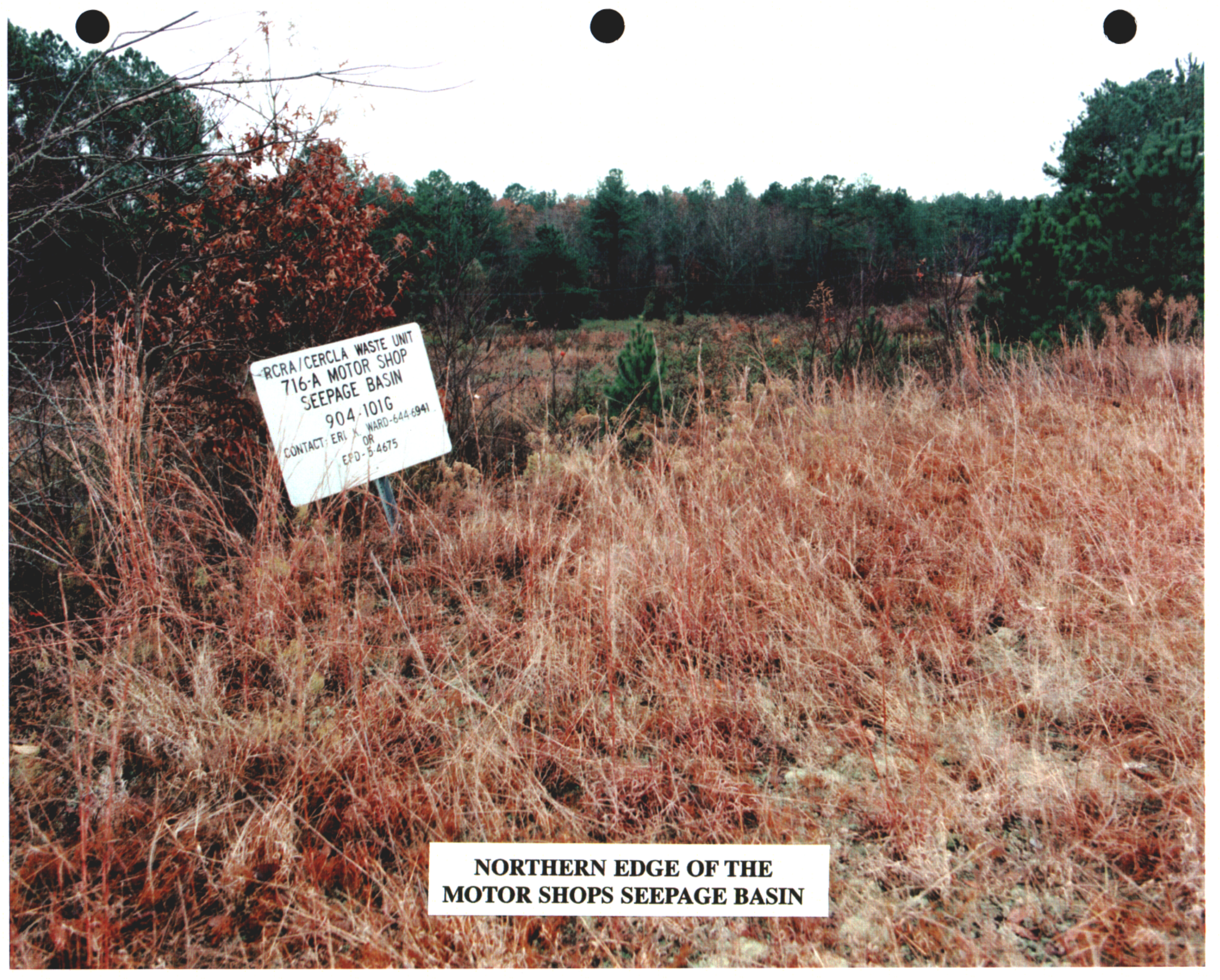




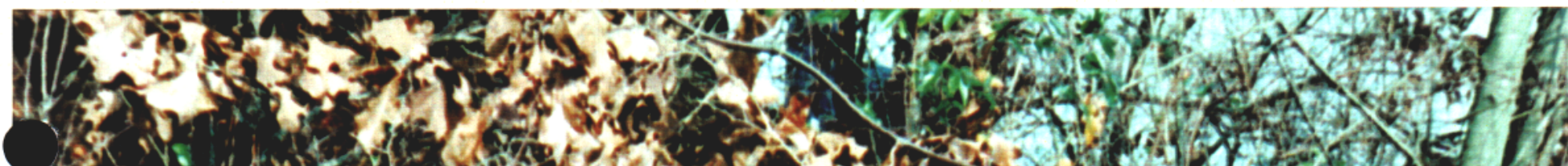

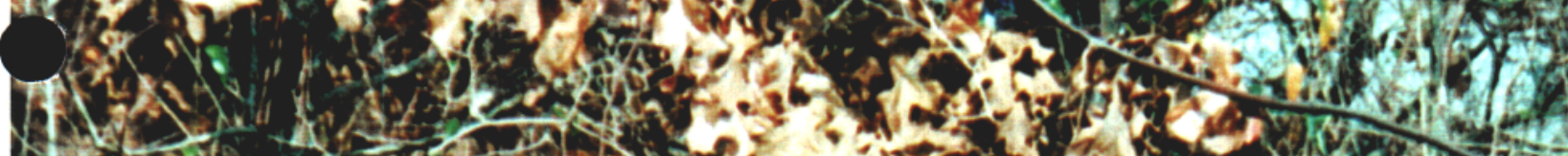

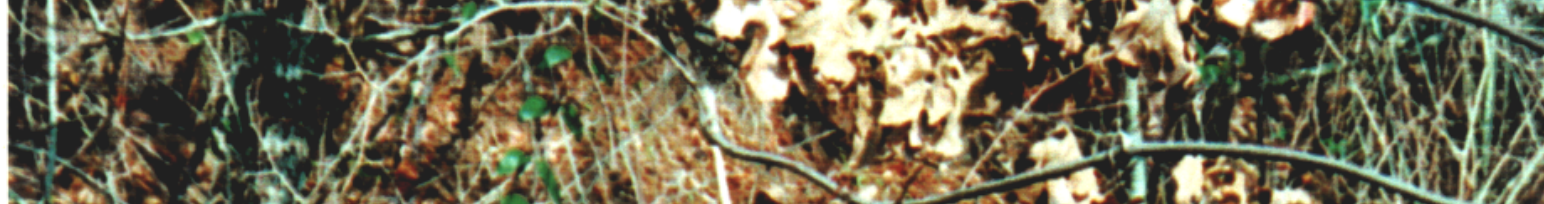

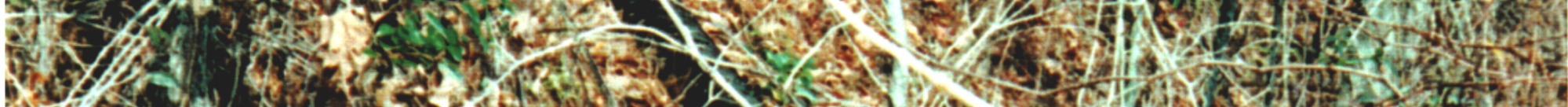

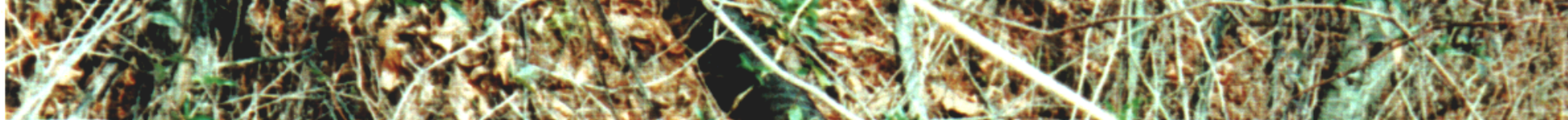
\&. 121. A n.

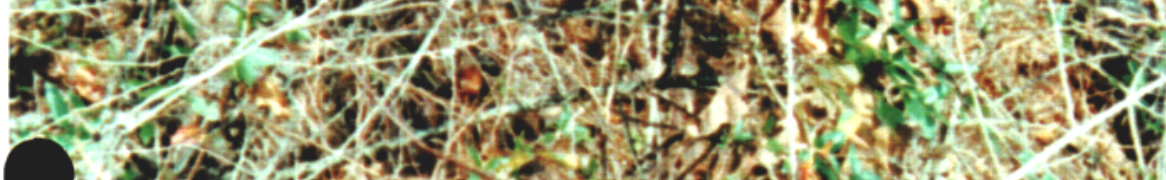

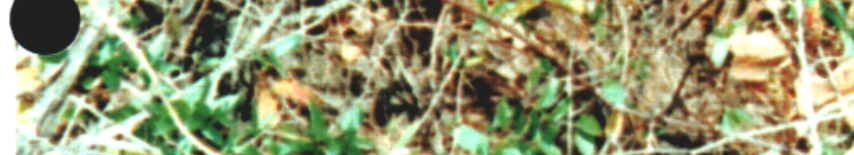

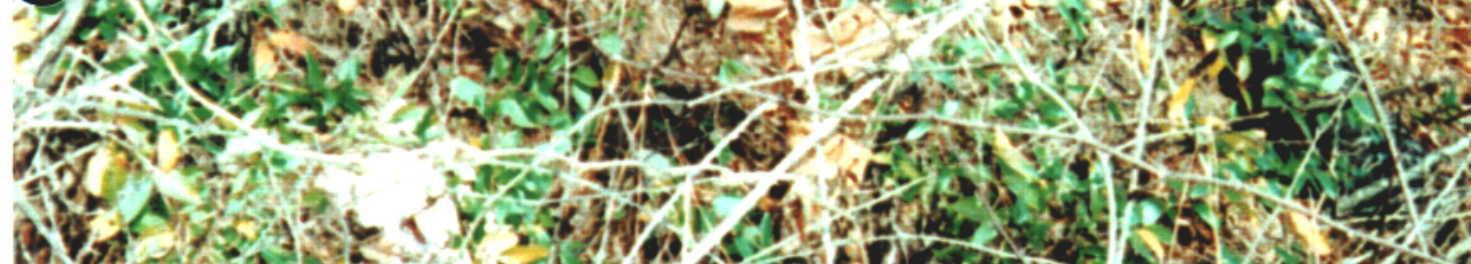

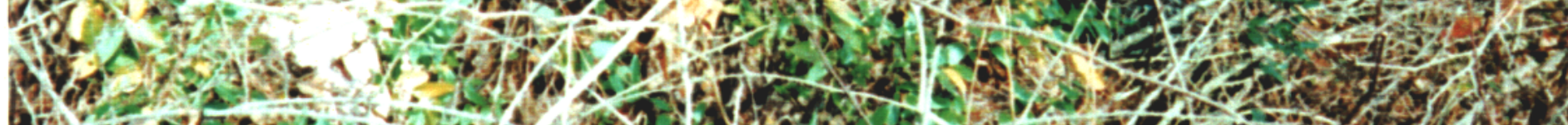

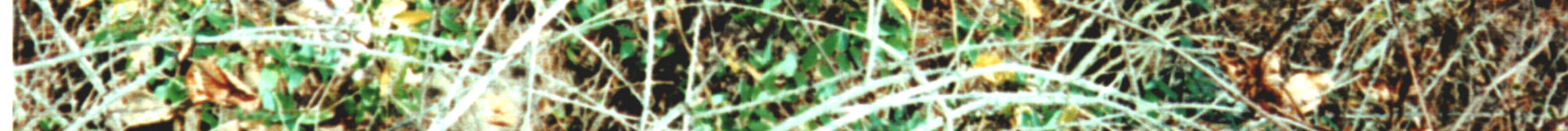

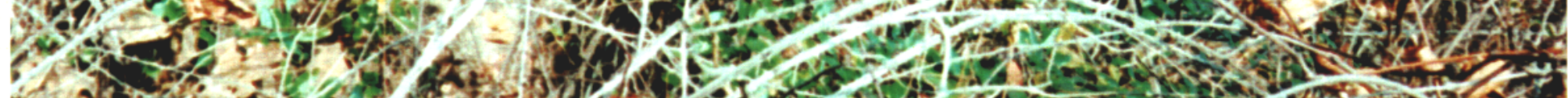

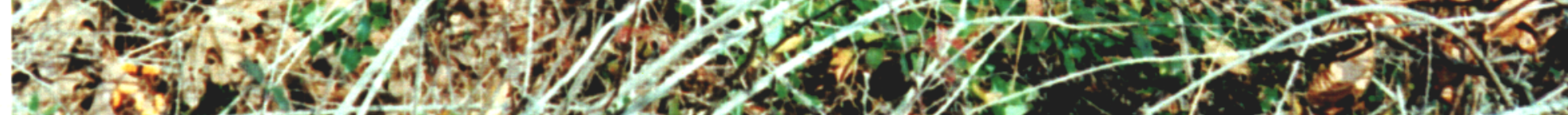

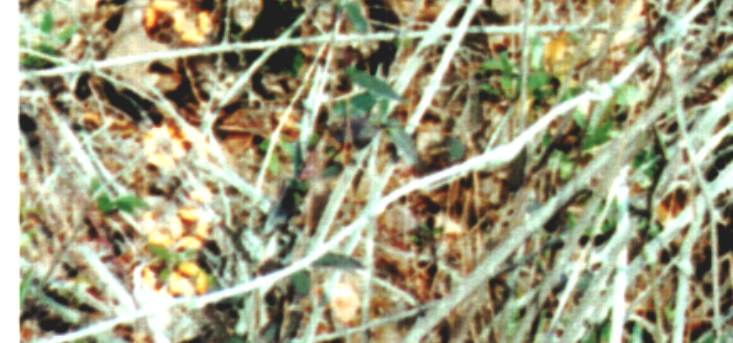
50.3 3 mod

\section{(1)}




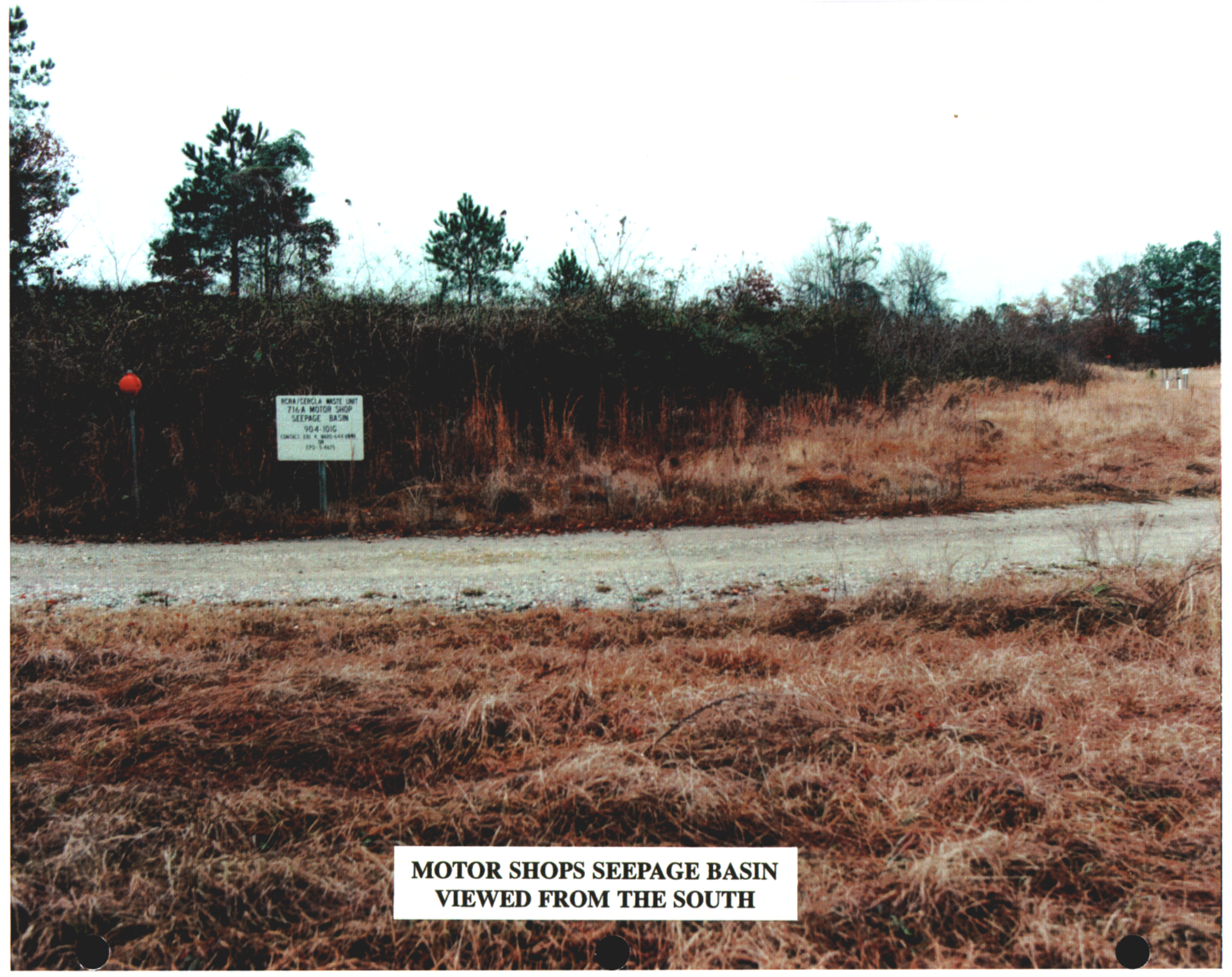




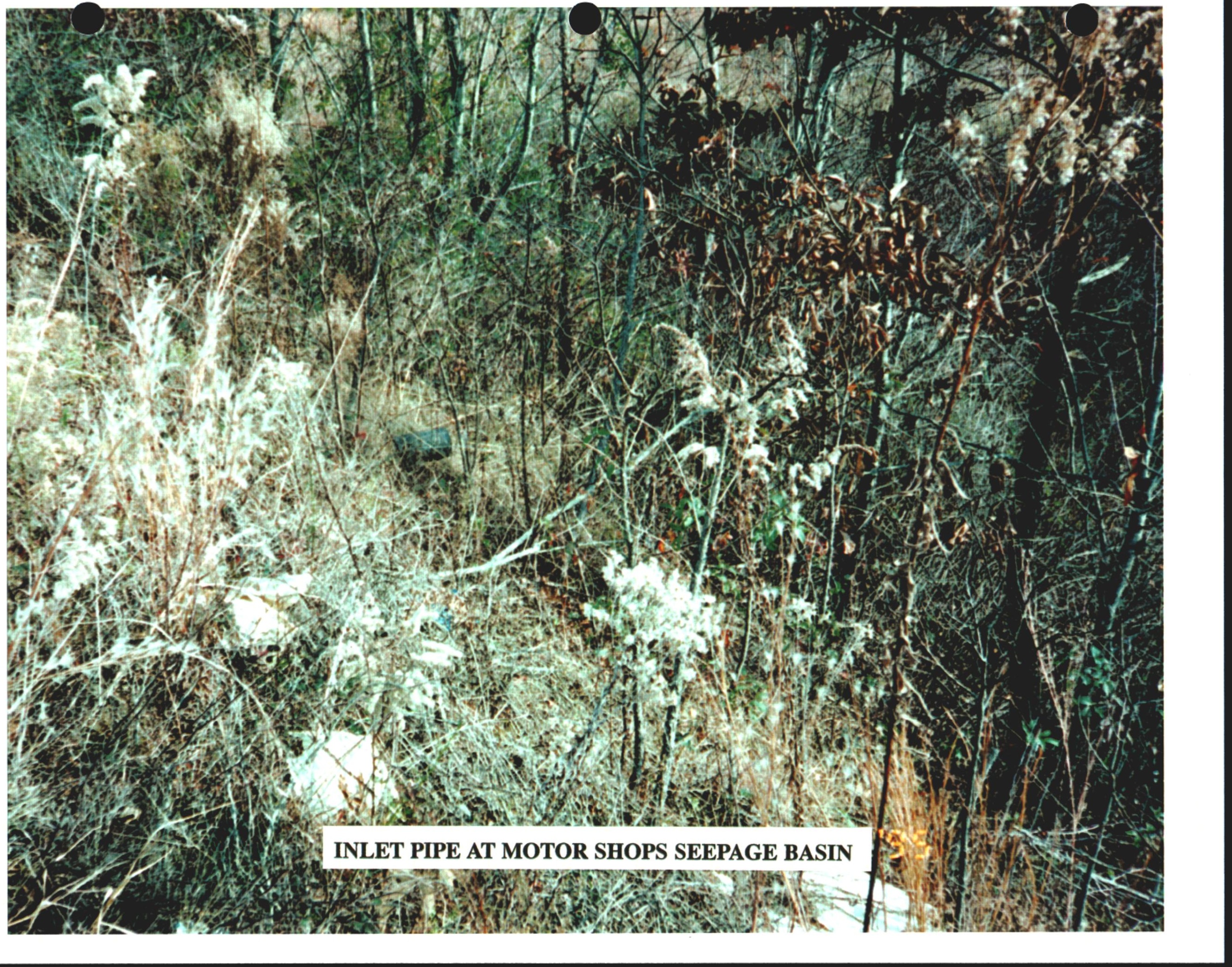


RFI/RI Work Plan for the

WSRC-RP-96-00111, Revision 0

Motor Shops Seepage Basin

March 1996

APPENDIX B

GROUNDWATER DATA 
ANALYTICAL DATA SUMMARY

WELL CLUSTER AOB

\begin{tabular}{|c|c|c|c|c|c|c|c|c|c|c|c|}
\hline $\begin{array}{lr} & \text { Well ID: } \\
& \text { Date: } \\
\text { Analyte } & \\
\end{array}$ & $\begin{array}{c}\text { AOB1 } \\
1 / 20 / 91\end{array}$ & $4 / 22 / 91$ & $8 / 4 / 91$ & 11/13/91 & $1 / 7 / 92$ & $5 / 25 / 92$ & $7 / 14 / 92$ & $11 / 17 / 92$ & $1 / 22 / 93$ & $4 / 17 / 93$ & $7 / 3 / 93$ \\
\hline \multicolumn{12}{|l|}{ Metals $(\mu \mathrm{g} / \mathrm{L})$} \\
\hline Aluminum, total recoverable & -- & -. & -- & -- & -- & -- & -- & -- & -- & -- & -- \\
\hline Antimony, dissolved & -- & -- & -- & -- & -- & - & -- & -- & -- & -- & -- \\
\hline Antimony, total recoverable & -- & -- & -- & -- & -- & -- & -- & -- & -- & -- & -- \\
\hline Arsenic, dissolved & -- & -- & - & -. & -- & -- & -- & -- & -- & -- & -- \\
\hline Barium, dissolved & $10 / 9.5$ & -- & -- & $12.6 / 12.9$ & 13.4 & $20.7 / 14.9$ & 13.7 & - & -- & -- & -- \\
\hline Barium, total recoverable & - & -- & -- & -- & -- & -- & -- & 12.9 & 12.5 & $\cdots$ & -- \\
\hline Cadmium, dissolved & -- & -- & -- & -- & -- & $--/ 1.1$ & -- & -- & -- & -- & -- \\
\hline Calcium, dissolved & $1400 / 1300$ & -- & -- & -- & -- & -- & -- & & -- & - & -- \\
\hline Calcium, total recoverable & -- & - & -- & -- & -- & -- & -- & & 1530 & -- & - \\
\hline Chromium, dissolved & -- & -- & -- & -- & -- & - & -- & -- & -- & -- & -- \\
\hline Chromium, total recoverable & -- & -- & -- & - & -- & - & -- & -- & - & -- & -- \\
\hline Cobalt, dissolved & -- & -- & -- & -- & -- & 5.8 & -- & -- & -- & -- & -- \\
\hline Copper, dissolved & -- & -- & -- & -- & -- & 5.2 & 4.17 & -- & -- & -- & -- \\
\hline Copper, total recoverable & -- & -- & -- & -- & -- & -- & -- & - & -- & -- & -- \\
\hline Iron, dissolved & $8.6 / 5.9$ & -- & -- & -- & -- & $25.1 / 4$ & 9.68 & -- & -- & -- & -- \\
\hline Iron, total recoverable & -- & -- & -- & -- & -- & -- & -- & 5.28 & 7.11 & -- & 13.1 \\
\hline Lead, dissolved & $--/ 3$ & -- & -- & -- & -- & -- & -- & -- & -- & -- & -- \\
\hline Lead, total recoverable & -- & - & - & -- & -- & -- & -- & -- & -- & - & - \\
\hline Magnesium, dissolved & $570 / 530$ & -- & -- & -- & -- & -- & -- & - & -- & -- & -- \\
\hline Magnesium, total recoverable & -- & -- & -- & -- & -- & -- & -- & -- & 693 & -- & - \\
\hline Manganese, dissolved & $13 / 12$ & -- & -- & -- & 15.6 & $18.1 / 17$ & 15.9 & -- & -- & $\cdots$ & - \\
\hline Manganese, total recoverable & -- & -- & -- & -- & -- & -- & -- & 16.8 & 15.5 & $-\cdot$ & - \\
\hline Mercury, dissolved & $0.38 / 0.33$ & -- & -- & $0.349 / 0.243$ & 0.297 & 0.228 & -- & -- & -- & -- & - \\
\hline Nickel, dissolved & -- & -- & -- & -- & -- & 3.9 & -- & -- & -- & -- & -- \\
\hline Nickel, total recoverable & -- & -- & -- & -- & -- & -- & -- & - & -- & -- & -- \\
\hline Selenium, dissolved & -- & -- & -- & - & -- & -- & -- & -- & -- & -- & -- \\
\hline Silica, dissolved & -- & -- & -- & -- & -- & -- & -- & - & -- & - & -- \\
\hline Silica, total recoverable & -- & -- & -- & -- & -- & -- & -- & -- & 7780 & -- & -- \\
\hline Silver, dissolved & -- & -- & -- & -- & -- & -- & -- & -- & -- & -- & -- \\
\hline Sodium, dissolved & $5000 / 4700$ & -- & -- & -- & 3030 & $3180 / 3150$ & 2940 & -- & -- & -- & -- \\
\hline Sodium, total recoverable & -- & -- & -- & -- & -- & -- & -- & 3690 & 3360 & -- & -- \\
\hline Thallium, dissolved & -- & -- & -- & -- & -- & $\cdots$ & -- & -- & -- & -- & -- \\
\hline Tin, dissolved & -- & -- & -- & -- & -- & $--/ 5.5$ & -- & -- & -- & -- & -- \\
\hline
\end{tabular}

I:X728475VDATAIWELLDATA.XLS:sorted aoh 
ANALYTICAL DATA SUMMARY

WELL CLUSTER AOB

\begin{tabular}{|c|c|c|c|c|c|c|c|c|c|c|c|}
\hline $\begin{array}{lr} & \text { Well ID: } \\
& \text { Date: } \\
\text { Analyte } & \\
\end{array}$ & $\begin{array}{c}\mathrm{AOB1} \\
1 / 20 / 91\end{array}$ & $4 / 22 / 91$ & $8 / 4 / 91$ & $11 / 13 / 91$ & $1 / 7 / 92$ & $5 / 25 / 92$ & $7 / 14 / 92$ & $11 / 17 / 92$ & $1 / 22 / 93$ & $4 / 17 / 93$ & $7 / 3 / 93$ \\
\hline Tin, total recoverable & -- & -- & -- & -- & -- & - & -- & $\overline{--}$ & -- & -- & -- \\
\hline Vanadium, dissolved & -- & -- & -- & -- & -- & 4.2 & -- & -- & -- & -- & - \\
\hline Zinc, dissolved & -- & - & -- & $5.53 / 4.54$ & -- & $6.3 / 5.3$ & 4.79 & -- & -- & -- & -- \\
\hline Zinc, total recoverable & -- & -- & -- & -- & -- & -- & -- & -- & -- & -- & -- \\
\hline \multicolumn{12}{|l|}{ Inorganics } \\
\hline Chloride (mg/L) & $5.29 / 5.03$ & - & -- & -- & 5 & $4.75 / 4.76$ & 4.29 & 5.04 & 4.71 & -- & -. \\
\hline Cyanide $(\mu \mathrm{g} / \mathrm{L})$ & -- & -- & -- & - & -- & -- & -- & -- & -- & $\cdots$ & -- \\
\hline Fluoride (mg/L) & -- & -- & -- & -- & -- & -- & -- & - & -- & -- & -- \\
\hline Nitrate as nitrogen $(\mathrm{mg} / \mathrm{L})$ & $1.6 / 1.07$ & -- & -- & -- & 1.05 & $1.08 / 1.24$ & -- & -- & -- & -- & -- \\
\hline Nitrate-nitrite as nitrogen $(\mathrm{mg} / \mathrm{L})$ & -- & -- & -- & -- & -- & $1.17 / 1.24$ & 1.3 & 1.39 & 1.2 & -- & -- \\
\hline Sulfate $(\mathrm{mg} / \mathrm{L})$ & -- & -- & -- & -- & -- & 0.472 & -- & -- & $-\cdot$ & -- & -- \\
\hline Total phosphates (as P) (mg/L) & $35.9 /--$ & -- & -- & -- & -- & -- & -- & $\cdots$ & 0.07 & -- & -- \\
\hline \multicolumn{12}{|l|}{ General Chemistry } \\
\hline pH (std units) & $5.35 / 5.33$ & - & -- & -- & -- & -- & -- & -- & 5.39 & 5.24 & 5.21 \\
\hline Specific conductance $(\mu \mathrm{S} / \mathrm{cm})$ & $37.1 / 31$ & -- & -- & -- & -- & -- & - & -- & 40 & 28 & 30 \\
\hline Total dissolved solids (mg/L) & $70 / 50$ & -- & -- & -- & -- & -- & -- & -- & 31 & 18 & 26 \\
\hline Oil \& grease & -- & -- & - & -- & -- & $1.1 / 1.1$ & 1 & -- & -- & -- & -- \\
\hline Phenols $(\mu \mathrm{g} / \mathrm{L})$ & -- & -- & -- & -- & -- & -- & -- & -- & -- & -- & -- \\
\hline Total organic carbon $(\mathrm{mg} / \mathrm{L})$ & $2 / 2$ & - & -- & -- & -- & $2.14 / 1.34$ & 1 & 1.91 & -- & -- & -- \\
\hline Total organic halogens $(\mu \mathrm{g} / \mathrm{L})$ & $262 / 190$ & -- & 71.1 & -- & 80.1 & $123 / 57 / 142$ & 89.3 & 104 & 92.9 & -- & 54.8 \\
\hline Total Petroleum Hydrocarbons & -- & - & -- & -- & -- & $\cdots$ & - & -- & -- & -- & -- \\
\hline \multicolumn{12}{|l|}{ Radioactivity } \\
\hline Gross alpha (pCi/L) & -- & -- & -- & $2.3 / 2.32$ & -- & $2.7 / 2.41 .9$ & 3.3 & -- & -. & -- & -- \\
\hline Nonvolatile beta (pCi/L) & $2.3 /--$ & - & -- & $2.54 / 4.25$ & -- & $1.6 / 1.6 / 1.6$ & -- & -- & 2.13 & -- & -- \\
\hline Total activity (PCML) & -- & -- & -- & -- & -- & -- & -- & -- & $\cdots$ & -- & -- \\
\hline Radium, total alpha-emitting (pCi/L) & $2 / 1.6$ & -- & 2.8 & $1.3 / 2.5$ & 1 & 1.3 & -- & 1.2 & 1.8 & -- & -- \\
\hline Uranium alpha activity $(\mathrm{pCi} / \mathrm{L})$ & -- & -- & -- & -- & -- & -- & -- & -- & -- & -- & -- \\
\hline Antimony-125 & -- & -- & -- & -- & -- & -- & -- & $\cdots$ & -- & -- & -- \\
\hline Cerium-144 & - & -- & -- & -- & -- & - & -- & -- & -- & -- & $-\cdots$ \\
\hline Cesium-134 & -- & -- & -- & -- & - & -- & -- & -- & -- & -- & - \\
\hline Cesium-137 & -- & -- & -- & -- & -- & -- & -- & -- & -- & -- & -- \\
\hline
\end{tabular}


ANALYTICAL DATA SUMMARY

WELL CLUSTER AOB

\begin{tabular}{|c|c|c|c|c|c|c|c|c|c|c|c|}
\hline $\begin{array}{lr} & \text { Well ID: } \\
& \text { Date: } \\
\text { Analyte } & \\
\end{array}$ & $\begin{array}{c}\text { AOB1 } \\
1 / 20 / 91\end{array}$ & $4 / 22 / 91$ & $8 / 4 / 91$ & $11 / 13 / 91$ & $1 / 7 / 92$ & $5 / 25 / 92$ & $7 / 14 / 92$ & $11 / 17 / 92$ & $1 / 22 / 93$ & $4 / 17 / 93$ & $7 / 3 / 93$ \\
\hline Cobalt-57 & -- & -- & - & -- & - & - & - & -- & - & - & -- \\
\hline Cobalt -60 & -- & -- & -- & -- & -- & -. & -- & -- & -- & -- & -- \\
\hline Europium-154 & -- & -- & -. & -- & -- & -- & -- & - & -- & -. & -- \\
\hline Europium-155 & -- & $\cdots$ & -- & -- & - & -- & -- & -- & -. & -- & -. \\
\hline Manganese-54 & -- & -- & -- & -- & - & -- & -- & -- & - & -- & -- \\
\hline Neptunium-237 & -- & -- & -- & -- & - & -- & -- & -- & -- & - & -- \\
\hline Potassium-40 & -- & -- & -- & -- & -- & -- & -- & -- & -- & -. & -- \\
\hline Promethium-144 & -- & -- & -- & -- & -- & -- & -- & -- & -- & -- & -- \\
\hline Promethium-146 & -- & -- & -- & -- & -- & -- & -- & -- & - & -- & -- \\
\hline Radium-226 (pCi/L) & -- & -- & -- & -- & -- & $1.51 / 1.12 / 1.37$ & -- & -- & -- & -- & -- \\
\hline Radium-228 (pCi/L) & -- & -- & -- & -- & -- & -- & - & -- & -- & -- & -- \\
\hline Ruthenium-103 & -- & -- & -- & -- & -- & - & -- & - & $\ldots$ & - & -- \\
\hline Sodium-22 & -- & -- & -- & -- & -- & -- & -- & -- & -- & -- & -- \\
\hline Thorium-228 & -- & -- & -- & -- & -- & -- & -- & -- & -- & -- & -- \\
\hline Tritium (PCML) & $1.4 / 1.4$ & -- & -- & $1.34 / 0.759$ & -- & $\begin{array}{c}0.884 / 0.945 \\
1324.05 / 1707.60\end{array}$ & 1.47 & 0.788 & 1.02 & $\ldots$ &.- \\
\hline Tritium (pCi/L) & -- & -- & -- & -- & - & $/ 1609.18$ & -- & -- & -- & -- & -- \\
\hline Uranium-233/234 (pCi/L) & -- & -- & -. & -- & -- & -- & - & -- & -- & -- & -- \\
\hline Uranium-234 (pCi/L) & -- & -- & -- & -- & -- & -- & -- & -- & -- & -- & -- \\
\hline Uranium-235 (pCi/L) & -- & -- & -- & -- & -- & -- & -- & -- & -- & - & -- \\
\hline Uranium-238 (pCi/L) & -- & -- & -- & -- & -- & -- & -- & -- & - & -- & -- \\
\hline Zinc-65 & -- & -- & - & -- & -- & -- & -- & -- & -- & -- & - \\
\hline Volatile Organics (SW8240) $(\mu \mathrm{g} / \mathrm{L})$ & & & & & & & & & & & \\
\hline 1,1,1-Trichloroethane & -- & -- & -- & -- & -- & -- & -- & -- & $\cdots$ & -- & -- \\
\hline 1,1,2,2-Tetrachloroethane & -- & -- & -- & -- & -- & -- & -- & -. & -- & -- & $-\infty$ \\
\hline 1,1,2-Trichloroethane & -- & -- & -- & -- & -- & -- & -- & -- & -- & -- & -- \\
\hline 1,1-Dichloroethane & -- & -- & -- & -- & - & -- & -- & -- & -- & -- & -- \\
\hline 1,1-Dichloroethylene & -- & -- & -- & - & - & -- & -- & -- & -- & -- & -- \\
\hline 1,2-Dichloroethane & -- & -- & - & -- & -- & -- & -- & -- & -- & -- & -- \\
\hline 1,2-Dichloropropane & -- & 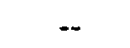 & -- & -- & -- & -- & -- & -- & -- & -- & -- \\
\hline 2-Chloroethyl vinyl ether & -- & -- & -- & -- & -- & -- & -- & -- & -- & -- & -- \\
\hline Benzene & -- & -- & -- & -- & - & -- & -- & -- & -- & -- & -- \\
\hline Bromodichloromethane & -- & -- & -- & -- & -- & -- & -- & -- & -- & -- & -- \\
\hline
\end{tabular}

I:1728475DATAIWELLDATA.XIS:sorted aob 
ANALYTICAL DATA SUMMARY

WELL CLUSTER AOB

\begin{tabular}{|c|c|c|c|c|c|c|c|c|c|c|c|}
\hline $\begin{array}{lr} & \text { Well ID: } \\
& \text { Date: } \\
\text { Analyte } & \\
\end{array}$ & $\begin{array}{c}\text { AOB1 } \\
1 / 20 / 91\end{array}$ & $4 / 22 / 91$ & $8 / 4 / 91$ & 11/13/91 & $1 / 7 / 92$ & $5 / 25 / 92$ & $7 / 14 / 92$ & 11/17/92 & $1 / 22 / 93$ & $4 / 17 / 93$ & $7 / 3 / 93$ \\
\hline Bromoform & -- & -- & -- & -- & -- & -- & -- & -- & -- & -- & -. \\
\hline Bromomethane (Methyl bromide) & -- & -- & -- & -- & -. & -- & -- & -- & -- & -- & -- \\
\hline Carbon tetrachloride & -- & -- & -- & -- & -. & -- & -- & -- & -- & -- & - \\
\hline Chlorobenzene & -- & -- & -- & -- & -- & -- & -- & -- & -- & -- & -- \\
\hline Chloroethane & -- & -- & -- & -- & -- & -- & -- & -- & -- & $\cdots$ & -- \\
\hline Chloroform & -- & -- & 1.2 & -- & -- & -- & -- & -- & -- & -- & -- \\
\hline Chloromethane (Methyl chloride) & -- & -- & -- & -- & -- & -- & -- & -- & -- & -- & -. \\
\hline cis-1,3-Dichloropropene & -- & -- & -- & -- & -- & -- & -- & -- & -- & -- & -- \\
\hline Dibromochloromethane & -- & -- & -- & -- & -- & -- & - & $-\cdot$ & - & -- & -- \\
\hline Ethylbenzene & -- & -- & -- & -- & -- & -- & -- & -- & -- & - & -. \\
\hline Methylene chloride (Dichloromethane) & -- & -- & -- & $6.6 / 7.8$ & -- & $\begin{array}{c}4.06 / 1.38 / 2.27 \\
66.8 / 58.6 / 58.9 / 5\end{array}$ & 35.8 & -- & -- & -- & -- \\
\hline Tetrachloroethylene & $148 / 105$ & 117 & 77 & $67.8 / 64.6 / 60.7$ & 56.3 & $6.7 / 68$ & 65 & 49 & 57.8 & 53.8 & 67 \\
\hline Toluene & -- & -- & -- & $1.9 / 2.5 / 56.1$ & -- & $1.42 / 1.49$ & -- & -- & -- & -- & -- \\
\hline trans-1,2-Dichloroethylene & -- & -- & -- & -- & -- & -- & -- & -- & -- & -- & -- \\
\hline trans-1,3-Dichloropropene & -- & -- & -- & -- & -- & -- & -- & -- & -- & -- & $-\cdot$ \\
\hline Trichloroethylene & $155 / 130$ & 121 & $50.7 / 77$ & $64.1 / 65.4$ & 49.7 & $57.9 / 59.3 / 62.5$ & 60.2 & 51.8 & 52.4 & 52.9 & 71 \\
\hline Trichlorofluoromethane & -- & -- & -- & -- & -- & -- & -- & -- & -- & -- & -- \\
\hline Vinyl chloride (Chloroethene) & -- & -- & -- & -- & -- & -- & -. & -- & -- & -- & -- \\
\hline Xylenes & -- & -- & -- & -- & -- & -- & -- & -- & -- & $-\cdot$ & -- \\
\hline \multicolumn{12}{|l|}{ Semivolatile Organics (SW8270) } \\
\hline Acenaphthene & -- & - & -- & -- & -- & -- & -- & -- & -- & -- & -- \\
\hline Acenaphthylene & -- & -. & -- & - & -. & - & -- & -- & -- & -- & -- \\
\hline Anthracene & -- & -- & -- & -- & -- & - & -- & $-\cdot$ & -- & -- & -- \\
\hline Benzidine & -- & - & -- & -- & -- & -- & -- & -- & -- & -- & - \\
\hline Benzo(a)anthracene & -- & -- & -- & -- & -- & -- & $\cdots$ & -- & -- & $-\cdot$ & -- \\
\hline Benzo(b)fluoranthene & -- & -- & -- & -- & -- & -- & -. & -- & -- & -- & -- \\
\hline Benzo(g,h,i)perylene & -- & -- & -- & -- & -- & -- & -- & -- & -- & -- & -- \\
\hline Benzo(a)pyrene & -- & -- & -- & -- & -- & -- & -- & -- & -- & -- & -- \\
\hline Benzo(k)fluoranthene & -- & -- & -- & -- & -- & -- & -- & -- & -- & -- & -- \\
\hline bis(2-Chloroethoxy) methane & -- & -- & -- & -- & - & -- & - & -- & -- & - & -- \\
\hline bis(2-Chloroethyl) ether & - & -- & -- & -- & -- & -- & -- & -- & -- & -- & -- \\
\hline bis(2-Chloroisopropyl) ether & -- & -- & -- & -- & -- & - & -- & -- & -- & -- & -- \\
\hline
\end{tabular}


ANALYTICAL DATA SUMMARY

WELL CLUSTER AOB

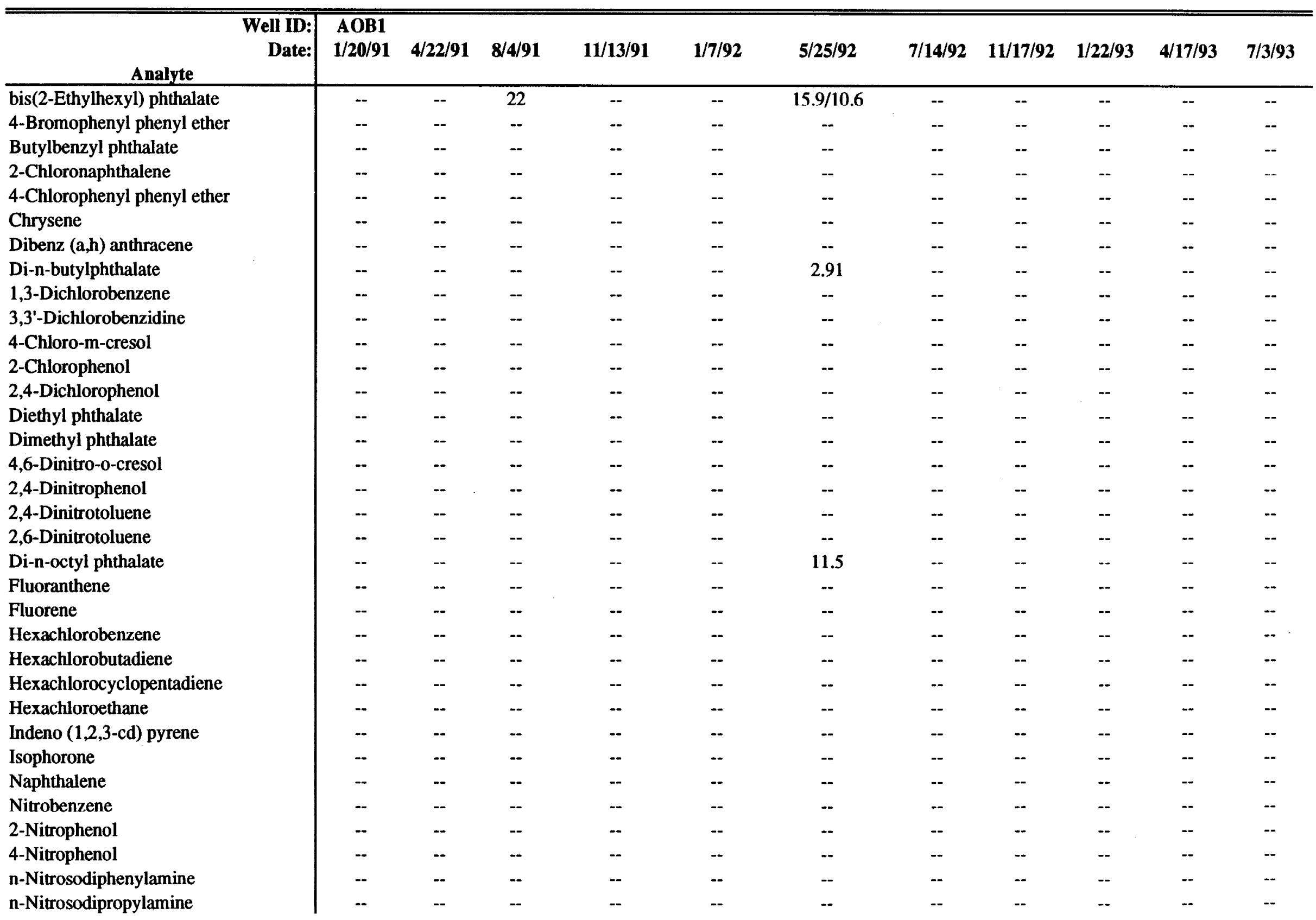

I:\728475DATAIWELLDATA.XLS:sorted aob 
ANALYTICAL DATA SUMMARY

WELL CLUSTER AOB

\begin{tabular}{|c|c|c|c|c|c|c|c|c|c|c|c|}
\hline $\begin{array}{lr} & \text { Well ID: } \\
& \text { Date: } \\
\text { Analyte } & \end{array}$ & $\begin{array}{c}\text { AOB1 } \\
1 / 20 / 91\end{array}$ & $4 / 22 / 91$ & $8 / 4 / 91$ & $11 / 13 / 91$ & $1 / 7 / 92$ & $5 / 25 / 92$ & $7 / 14 / 92$ & $11 / 17 / 92$ & $1 / 22 / 93$ & $4 / 17 / 93$ & $7 / 3 / 93$ \\
\hline Pentachlorophenol & -- & -- & -- & -- & - & - & - & -- & - & -- & $\ldots$ \\
\hline Phenanthrene & -- & -- & -- & -- & -- & -- & -- & -- & -- & -- & $\ldots$ \\
\hline Phenol & -- & -- & -- & -- & -- & -- & -- & -- & -- & -- & -- \\
\hline Pyrene & -- & -- & -- & -- & -- & -- & -- & -- & -- & -- & -- \\
\hline 1,2-Diphenylhydrazine & -- & -- & -- & -- & -- & -- & - & - & -- & -- & -- \\
\hline 2-Methyl-4,6-dinitrophenol & -- & - & -- & -- & -- & -- & -- & -- & -- & -- & -- \\
\hline \multicolumn{12}{|l|}{ Herbicides (SW8150) $(\boldsymbol{\mu g} / \mathrm{L})$} \\
\hline 2,4,5-TP (Silvex) & -- & -- & - & -- & -- & -- & -- & -- & -- & -- & -- \\
\hline 2,4-Dichlorophenoxyacetic acid (2,4-D) & -- & -- & - & -- & -- & -- & -- & -- & -- & -- & -- \\
\hline \multicolumn{12}{|l|}{ Pesticides (SW8080) $(\mu \mathrm{g} / \mathrm{L})$} \\
\hline Aldrin & -- & -- & - & - & -- & -- & -- & -- & -- & -- & -- \\
\hline Chlordane & -- & -- & -- & - & -- & -- & -- & -- & -- & -- & -- \\
\hline p,p'-DDD & -- & -- & -- & -- & -- & -- & -- & -- & -- & - & -- \\
\hline p,p'-DDE & -- & -- & -- & -- & -- & -- & -- & -- & -- & -- & -- \\
\hline$p, p^{\prime}-D D T$ & -- & -- & -- & - & -- & - & -- & -- & -- & -- & - \\
\hline Dieldrin & -- & -- & -- & -- & -- & -- & -- & -- & -- & -- & -- \\
\hline Endosulfan I & -- & -- & -- & -- & -- & -- & -- & -- & -- & -- & -- \\
\hline Endosulfan II & -- & -- & -- & -- & -- & -- & -- & -. & -. & -- & -- \\
\hline Endosulfan sulfate & -- & -- & -- & -- & -- & -- & -- & -- & -- & -- & -- \\
\hline Endrin & -- & -- & -- & -- & -- & -- & -- & -- & -- & -- & -- \\
\hline Endrin aldehyde & -- & -- & -- & -- & -- & -- & -- & -- & - & -- & -- \\
\hline Heptachlor & -- & -- & -- & -- & -- & -- & -- & -- & -- & -- & - \\
\hline Heptachlor epoxide & -- & - & -- & -- & - & -. & -- & -- & -- & -- & -- \\
\hline Lindane & -- & -- & -- & -- & - & -- & -- & -- & -- & -- & -- \\
\hline Toxaphene & -- & -- & -- & - & - & - & - & -- & -- & -- & -- \\
\hline
\end{tabular}

Note: Data qualifiers in table are those reported by the laboratory. 
ANALYTICAL DATA SUMMARY

WELL CLUSTER AOB

\begin{tabular}{|c|c|c|c|c|c|c|c|c|c|c|}
\hline $\begin{array}{lr} & \text { Well ID: } \\
& \text { Date: } \\
\text { Analyte } & \\
\end{array}$ & $\begin{array}{c}\text { AOB 1,cont. } \\
10 / 23 / 93\end{array}$ & $2 / 12 / 94$ & $7 / 8 / 94$ & $11 / 1 / 94$ & $\begin{array}{c}\text { AOB2 } \\
1 / 20 / 91\end{array}$ & $4 / 22 / 91$ & $8 / 4 / 91$ & $11 / 13 / 91$ & $2 / 16 / 92$ & $5 / 25 / 92$ \\
\hline Metals $(\mu \mathrm{g} / \mathrm{L})$ & & & & & & & & & & \\
\hline Aluminum, total recoverable & -- & 30.9 & -- & -- & -- & - & -. & -- & -. & -- \\
\hline Antimony, dissolved & -- & -- & -- & -- & -- & -- & -- & -- & $8.5 \mathrm{~J} / 4.2 \mathrm{~J}$ & -- \\
\hline Antimony, total recoverable & -. & $\cdots$ & -- & -- & -. & -- & -- & -- & -- & -- \\
\hline Arsenic, dissolved & -- & -- & -- & -- & - & -- & -- & -- & -- & -- \\
\hline Barium, dissolved & -- & -- & -- & -- & 4.6 & -- & -- & -- & $--/ 3.93$ & -- \\
\hline Barium, total recoverable & -- & & 11.9 & & -- & -- & -- & -- & -- & -- \\
\hline Cadmium, dissolved & -- & -- & -- & -- & -- & -- & -- & -- & $0.72 \mathrm{~J} / 1.5 \mathrm{~J}$ & -- \\
\hline Calcium, dissolved & -- & -- & -- & -- & $57000 / 58000$ & -- & -- & -- & -- & -- \\
\hline Calcium, total recoverable & -- & -- & -- & -- & -- & -- & -- & -- & -- & -- \\
\hline Chromium, dissolved & -- & -- & -- & -- & -- & -- & -. &.- & $1.2 \mathrm{~J}$ & -- \\
\hline Chromium, total recoverable & -- & -- & -- & -- & -- & -- & -- & -- & -- & -- \\
\hline Cobalt, dissolved & -- & -- & -- & -- & -- & -- & -- & -- & $0.95 \mathrm{~J}$ & -- \\
\hline Copper, dissolved & -- & -- & -- & -- & -- & -- & -- & 8.52 & $11.7 / 11.2$ & 6.7 \\
\hline Copper, total recoverable & -- & -- & -- & -- & -- & -- & -- & -- & -- & -- \\
\hline Iron, dissolved & -- & -- & -. & -- & 77 & -- & -- & 41 & $45.3 / 42$ & 19.3 \\
\hline Iron, total recoverable & -- & 30.9 & 8.6 & & -- & -- & -- & -- & -- & -- \\
\hline Lead, dissolved & - & -- & -- & -- & 13 & -- & -- & 5.81 & $6.7 \mathrm{~J} / 6.7 \mathrm{~J}$ & 5.55 \\
\hline Lead, total recoverable & -- & -- & -- & - & -- & $\cdots$ & -- & -- & -- & -- \\
\hline Magnesium, dissolved & -. & -- & -- & -- & 510 & - & -- & -- & -- & -- \\
\hline Magnesium, total recoverable & -- & -- & -- & -- & -- & -- & -- & -. & -- & -- \\
\hline Manganese, dissolved & -- & -- & -- & -- & $720 / 680$ & -- & -- & 8.22 & 5.86 .3 & 4.75 \\
\hline Manganese, total recoverable & -- & -- & -- & -- & -- & -- & -- & -- & -- & -- \\
\hline Mercury, dissolved & -- & -- & -- & -- & -- & -- & -- & -- & $\cdots$ & -- \\
\hline Nickel, dissolved & -- & -- & -- & -- & -- & -- & -- & 5.99 & $10.1 \mathrm{~J} / 10.1 \mathrm{~J}$ & 4.83 \\
\hline Nickel, total recoverable & -- & -- & -- & -- & -- & -- & -- & -- & -- & -- \\
\hline Selenium, dissolved & -- & -- & -- & -- & -- & -- & -- & -- & -- & -- \\
\hline Silica, dissolved & -- & -- & -- & -- & 7300 & -- & -- & -- & -- & -- \\
\hline Silica, total recoverable & -- & -- & -- & -- & -- & -- & -- & -- & -- & -- \\
\hline Silver, dissolved & -- & - & - & -- & -- & -- & -- & -- & -- & -- \\
\hline Sodium, dissolved & -- & -- & -- & - & 1800 & -- & $\cdots$ & 1930 & $2450 / 2230$ & 2430 \\
\hline Sodium, total recoverable & -- & -- & -- & -- & -- & -- & -- & $-\cdot$ & $-\cdots$ & -- \\
\hline Thallium, dissolved & -- & -- & -- & -- & -- & - & -- & -- & -- & - \\
\hline Tin, dissolved & -- & - & -- & -- & -- & -- & -- & -- & -- & -- \\
\hline
\end{tabular}


ANALYTICAL DATA SUMMARY

WELL CLUSTER AOB

\begin{tabular}{|c|c|c|c|c|c|c|c|c|c|c|}
\hline $\begin{array}{lr} & \begin{array}{r}\text { Well ID: } \\
\text { Date: }\end{array} \\
\text { Analyte } & \\
\end{array}$ & $\begin{array}{c}\text { AOB 1,cont. } \\
10 / 23 / 93\end{array}$ & $2 / 12 / 94$ & $7 / 8 / 94$ & 11/1/94 & $\begin{array}{l}\text { AOB2 } \\
1 / 20 / 91\end{array}$ & $4 / 22 / 91$ & $8 / 4 / 91$ & $11 / 13 / 91$ & $2 / 16 / 92$ & $5 / 25 / 92$ \\
\hline Tin, total recoverable & -- & -- & -- & -- & -- & -- & -- & - & -- & -- \\
\hline Vanadium, dissolved & -- & $-\cdot$ & -- & -- & -- & -- & -- & - & -- & -- \\
\hline Zinc, dissolved & -- & -- & -- & -- & -- & -- & -- & 25.3 & $22.1 / 23.2$ & 14.5 \\
\hline Zinc, total recoverable & -- & -- & 18.4 & -- & -- & -- & -- & -- & - &.- \\
\hline \multicolumn{11}{|l|}{ Inorganics } \\
\hline Chloride (mg/L) & -- & -- & -- & - & $1.7 / 1.87$ & -- & -- & 1.87 & $2.65 / 2.74$ & 1.8 \\
\hline Cyanide $(\mu \mathrm{g} / \mathrm{L})$ & -- & -- & -- & -- & -- & -- & -- & -- & -- & -- \\
\hline Fluoride (mg/L) & -- & - & -- & -- & -- & -- & -- & -- & -- & -- \\
\hline Nitrate as nitrogen $(\mathrm{mg} / \mathrm{L})$ & - & -- & -- & -- & 0.86 & -- & - & 0.66 & $0.932 / 0.902$ & -- \\
\hline Nitrate-nitrite as nitrogen $(\mathrm{mg} / \mathrm{L})$ & -- & -- & -- & -- & -- & -- & -- & -- & $0.85 / 0.72$ & 0.83 \\
\hline Sulfate $(\mathrm{mg} / \mathrm{L})$ & -- & -- &.- & -- & 1.33 & -- & -- & -- & 0.3970 .365 & -- \\
\hline Total phosphates (as P) (mg/L) & -- & -- & -- & -- & - & -- & -- & - & -- & -- \\
\hline \multicolumn{11}{|l|}{ General Chemistry } \\
\hline pH (std units) & $5.6 / 5.45$ & -- & -- & - & 5.41 & -- & -- & -- & - & -. \\
\hline Specific conductance $(\mu \mathrm{S} / \mathrm{cm})$ & $35.3 / 39.4 / 37.4$ & -- & -- & -- & 15 & -- & -- & -- & -- & -- \\
\hline Total dissolved solids (mg/L) & $35 / 30 / 36$ & -- & -- & -- & 29 & -- & -- & - & -- & -- \\
\hline Oil \& grease & $2.65 / 2.2$ & 3.8 & -- & -- & -- & -- & -- & -- & $21.7 / 11.6 / 11.3$ & 3.5 \\
\hline Phenols $(\mu \mathrm{g} / \mathrm{L})$ & -- & -- & -- & -- & -- & -- & -- & -- & -. & -- \\
\hline Total organic carbon $(\mathrm{mg} / \mathrm{L})$ & -- & -- & -- & - & 1 & -- & -- & -- & $1.31 / 1.31 / 2.04$ & 2 \\
\hline Total organic halogens $(\mu \mathrm{g} / \mathrm{L})$ & -- & 68.7 & 69.6 & -- & -- & -- & -- & $\cdots$ & $23.8 / 50.519 .8$ & -- \\
\hline Total Petroleum Hydrocarbons & -- & -- & -- & -- & -- & -- & -- & 18 & $22.3 / 19$ & -- \\
\hline \multicolumn{11}{|l|}{ Radioactivity } \\
\hline Gross alpha $(\mathrm{pCi} / \mathrm{L})$ & -- & -- & 2.95 & -- & $--/ 2.2$ & -- & -- & 2.2 & $1.1 / 1.1$ & -- \\
\hline Nonvolatile beta $(\mathrm{pCi} / \mathrm{L})$ & -- & -- & 2.33 & -- & 2.7 & -- & -- & -- & $3.4 / 2.7$ & -- \\
\hline Total activity (PCML) & -- & -- & -- & -- & -- & -- & -- & -- & - & -- \\
\hline Radium, total alpha-emilting (pCi/L) & -- & -- & 1 & -- & 1 & -- & 1.7 & -- & -- & -- \\
\hline Uranium alpha activity $(\mathrm{pCi} / \mathrm{L})$ & -- & -- & -- & -- & - & -- & -- & -- & -- & -- \\
\hline Antimony-125 & -- & -- & -- & -- & -- & -- & -- & -- & -- & -- \\
\hline Cerium-144 & -- & -- & -- & -- & - & -- & -- & -- & -- & -- \\
\hline Cesium-134 & -- & -- & -- & -- & -- & -- & - & -- & -- & -- \\
\hline Cesium-137 & -- & -- & -- & -- & -- & - & -- & -- & - & -- \\
\hline
\end{tabular}


ANALYTICAL DATA SUMMARY

WELL CLUSTER AOB

\begin{tabular}{|c|c|c|c|c|c|c|c|c|c|c|}
\hline $\begin{array}{lr} & \text { Well ID: } \\
& \text { Date: } \\
\text { Analyte } & \\
\end{array}$ & $\begin{array}{c}\text { AOB } 1, \text { cont. } \\
10 / 23 / 93\end{array}$ & $2 / 12 / 94$ & $7 / 8 / 94$ & $11 / 1 / 94$ & $\begin{array}{c}\text { AOB2 } \\
1 / 20 / 91\end{array}$ & $4 / 22 / 91$ & $8 / 4 / 91$ & $11 / 13 / 91$ & $2 / 16 / 92$ & $5 / 25 / 92$ \\
\hline Cobalt-57 & -- & -- & -- & -- & -- & -- & -- & -- & -- & -- \\
\hline Cobalt -60 & -- & -- & -- & -- & -- & -- & - & -- & -- & -- \\
\hline Europium-154 & - & -- & -- & -- & -. & -- & -- & -- & -- & -- \\
\hline Europium-155 & -- & -- & -- & -- & -- & -- & -- & - & 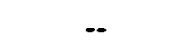 & - \\
\hline Manganese-54 & -- & -- & -- & -- & -- & -- & -- & -- & -. & -- \\
\hline Neptunium-237 & -- & -- & -- & -- & -- & -. & -- & -- & -. & -- \\
\hline Potassium-40 & -- & -- & -. & -- & -- & -- & -- & -- & -- & -- \\
\hline Promethium-144 & -- & -- & - & -- & -- & -- & -- & -- & -- & - \\
\hline Promethium-146 & -- & -- & -- & -- & -- & -- & -- & -. & $\ldots$ & -- \\
\hline Radium-226 (pCi/L) & -- & -. & -- & - & -- & -- & -- & -- & $2.4 / 0.1$ & -- \\
\hline Radium-228 (pCi/L) & -- & -- & -- & -- & -- & -- & -- & -- & $0.3 / 0.4$ & -- \\
\hline Ruthenium-103 & -- & -- & -- & -- & -- & -- & -- & -- & -- & -- \\
\hline Sodium-22 & -- & -- & -- & -- & -- & -- & -- & -- & -- & -- \\
\hline Thorium-228 & -- & -- & -- &.- & -- & - & -- & -- & -. & - \\
\hline Tritium (PCML) & -- & -- & -- & -- & 1.2 & -- & -- & 11.8 & -- & 1.04 \\
\hline Tritium (pCi/L) & -- & -- & - & -- & -- & - & -- & -- & $1400 / 1600$ & -- \\
\hline Uranium-233/234 (pCi/L) & -- & -- & -- & -- & -- & -- & -- & -- & -- & -- \\
\hline Uranium-234 (pCi/L) & -- & -- & -- & -- & -- & -- & -- & -- & -- & $\cdots$ \\
\hline Uranium-235 (pCi/L) & -- & -. & -- & -- & -- & -- & -- & -- & - & -- \\
\hline Uranium-238 (pCi/L) & -- & $\cdots$ & -- & -- & -- & -- & -- & -- & -- & -- \\
\hline Zinc-65 & - & - & -- & - & -- & -- & -- & -- & -- & -- \\
\hline \multicolumn{11}{|l|}{ Volatile Organics (SW8240) $(\mu \mathrm{g} / \mathrm{L})$} \\
\hline 1,1,1-Trichloroethane & -- & -- & -- & -- & -- & -- & -- & - & -- & -- \\
\hline 1,1,2,2-Tetrachloroethane & -- & -- & -- & -- & -- & -- & -- & -- & -- & -- \\
\hline 1,1,2-Trichloroethane & -- & -- & -- & -- & -- & -- & -- & -- & -- & -- \\
\hline 1,1-Dichloroethane & -- & -- & -- & -- & -- & -- & -- & -- & - & -- \\
\hline 1,1-Dichloroethylene & -- & -- & -- & -- & -- & -- & -- & -- & -- & -- \\
\hline 1,2-Dichloroethane & -- & -- & -- & -- & -- & -- & -- & -- & -- & -- \\
\hline 1,2-Dichloropropane & -- & -- & -- & -- & -- & -- & -- & -- & -- & -- \\
\hline 2-Chloroethyl vinyl ether & -- & -- & -- & -- & -- & -- & $\cdots$ & -- & -- & -- \\
\hline Benzene & -- & -- & -- & -- & -- & - & -- & -- & -- & -- \\
\hline Bromodichloromethane & -- & -- & -- & -- & -- & -- & -- & - & -- & -- \\
\hline
\end{tabular}

I:1728475DATAIWELLDATA.XILS:sorted aob 
ANALYTICAL DATA SUMMARY

WELL CLUSTER AOB

\begin{tabular}{|c|c|c|c|c|c|c|c|c|c|c|}
\hline $\begin{array}{lr} & \text { Well ID: } \\
& \text { Date: } \\
\text { Analyte } & \\
\end{array}$ & $\begin{array}{c}\text { AOB 1,cont. } \\
10 / 23 / 93\end{array}$ & $2 / 12 / 94$ & 7/8/94 & $11 / 1 / 94$ & $\begin{array}{c}\text { AOB2 } \\
1 / 20 / 91\end{array}$ & $4 / 22 / 91$ & $8 / 4 / 91$ & $11 / 13 / 91$ & $2 / 16 / 92$ & $5 / 25 / 92$ \\
\hline Bromoform & -- & -- & -- & -- & -- & $\cdots$ & -- & $\cdots$ & - & -- \\
\hline Bromomethane (Methyl bromide) & -- & -- & - & -- & -- & -- & -- & -- & -- & -- \\
\hline Carbon tetrachloride & -- & -- & -- & -- & -- & -. & -- & -- & -- & -- \\
\hline Chlorobenzene & -- & -- & -- & -- & -- & -- & -- & -- & -- & -- \\
\hline Chloroethane & -- & -- & -- & -- & -- & -- & -- & -- & -- & -- \\
\hline Chloroform & -- & -- & 1.2 & -- & -- & -- & -- & -- & -- & -- \\
\hline Chloromethane (Methyl chloride) & -- & -- & -- & -- & -- & -- & -- & -- & -- & -- \\
\hline cis-1,3-Dichloropropene & -- & -- & -- & -- & -- & -- & -- & -- & -- & -- \\
\hline Dibromochloromethane & -- & -- & -- & -- & -- & -- & -- & -- & -- & -- \\
\hline Ethylbenzene & -- & -- & -- & -- & -- & -. & - & -- & $--/ 1.45$ & -- \\
\hline Methylene chloride (Dichloromethane) & $17 / 2.9$ & -- & 40 & - & $--/ 1.92$ & -- & -- & $1.92 \mathrm{~J}$ & $3.06 \mathrm{~J}$ & $1.08 \mathrm{~J}$ \\
\hline Tetrachloroethylene & $64 / 65.5$ & $50 / 47$ & 48.5 & 35.7 & -- & -- & -- & -- & -- & -- \\
\hline Toluene & -- & -- & -- & -- & -- & -- & -- & 3.96 & $3.55 / 6.67$ & -- \\
\hline trans-1,2-Dichloroethylene & -- & -- & -- & -- & -- & -- & -- & -- & -- & -- \\
\hline trans-1,3-Dichloropropene & -- & -- & -- & - & -- & -- & -- & -- & -- & -- \\
\hline Trichloroethylene & $58.7 / 62.2$ & $51.5 / 43.7$ & -- & 39.5 & 1.8 & 1.8 & -- & -- & -- & -- \\
\hline Trichlorofluoromethane & -- & -- & -- & -- & -- & -- & -- & -- & -- & -- \\
\hline Vinyl chloride (Chloroethene) & -- & -- & -- & -- & -- & - & -- & -- & -- & -- \\
\hline Xylenes & -- & -- & -- & -- & - & -- & -- & 2 & $4.66 / 8.9$ & 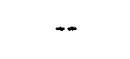 \\
\hline \multicolumn{11}{|l|}{ Semivolatile Organics (SW8270) } \\
\hline Acenaphthene & -- & -- & -- & - & -- & -- & -- & -- & -- & -- \\
\hline Acenaphthylene & -- & -. & - & -- & -- & -- & -- & - & - & -. \\
\hline Anthracene & -- & -- & -- & -- & -- & -- & -- & -- & -- & -- \\
\hline Benzidine & -- & -- & -- & -- & -- & -- & -- & -- & -- & -- \\
\hline Benzo(a)anthracene & - & - & -- & -- & - & -- & - & -- & -- & -- \\
\hline Benzo(b)fluoranthene & -- & -- & -- & -- & -- & -- & -- & -- & -- & -- \\
\hline Benzo(g,h,i)perylene & -- & -- & -- & -- & -- & -- & -- & -- & -- & -- \\
\hline Benzo(a)pyrene & -- & -- & -- & -- & -- & -- & -- & -- & -- & -- \\
\hline Benzo(k)fluoranthene & -- & -- & -- & -- & -- & -- & -- & -- & -- & -- \\
\hline bis(2-Chloroethoxy) methane & -- & -- & -- & -- & -- & -- & -- & -- & -- & -- \\
\hline bis(2-Chloroethyl) ether & -- & -- & -- & -- & -- & -- & - & -- & -- & -- \\
\hline bis(2-Chloroisopropyl) ether & -- & $-\cdot$ & - & -- & -- & -- & -- & -- & -- & -- \\
\hline
\end{tabular}


ANALYTICAL DATA SUMMARY

WELL CLUSTER AOB

\begin{tabular}{|c|c|c|c|c|c|c|c|c|c|c|}
\hline $\begin{array}{lr} & \text { Well ID: } \\
& \text { Date: } \\
\text { Analyte } & \\
\end{array}$ & $\begin{array}{c}\text { AOB 1,cont. } \\
10 / 23 / 93\end{array}$ & $2 / 12 / 94$ & 7/8/94 & $11 / 1 / 94$ & $\begin{array}{c}\text { AOB2 } \\
1 / 20 / 91\end{array}$ & $4 / 22 / 91$ & $8 / 4 / 91$ & $11 / 13 / 91$ & $2 / 16 / 92$ & $5 / 25 / 92$ \\
\hline bis(2-Ethylhexyl) phthalate & - & -- & - & $\cdots$ & 34 & $\overline{--}$ & 34 & $\overline{--}$ & $9.69 \mathrm{~J} / 23 \mathrm{~J} / 15.5 \mathrm{~J}$ & $\ldots$ \\
\hline 4-Bromophenyl phenyl ether & -- & -- & -- & -- & -- & -- & -- & -- & -- & -- \\
\hline Butylbenzyl phthalate & -- & -- & -- & -- & -- & -- & -- & -- & -- & -- \\
\hline 2-Chloronaphthalene & - & - & -- & -- & -- & - & -- & - & -- & -- \\
\hline 4-Chlorophenyl phenyl ether & -- & -- & -- & -- & -- & $-\cdot$ & -- & -- & -- & -- \\
\hline Chrysene & -- & -- & -- & -- & - & -- & -- & -- & -- & -- \\
\hline Dibenz $(\mathrm{a}, \mathrm{h})$ anthracene & -- & -- & -- & -- & -- & -- & -- & -- & -- & -- \\
\hline Di-n-butylphthalate & -- & -- & -- & -- & -- & -- & - & -- & $3.31 \mathrm{~J} / 7.6 \mathrm{~J} / 5.44 \mathrm{~J}$ & -- \\
\hline 1,3-Dichlorobenzene & -- & -- & -- & -- & -- & -- & -- & - & -- & -- \\
\hline 3,3'-Dichlorobenzidine & -- & -- & -- & -- & -- & -- & -- & -- & -- & -- \\
\hline 4-Chloro-m-cresol & -- & -- & -- & - & -- & -- & -- & -- & -- & $\cdots$ \\
\hline 2-Chlorophenol & -- & -- & -- & -- & -- & -- & - & -- & -- & -- \\
\hline 2,4-Dichlorophenol & - & -- & -- & -- & -- & -- & -- & -- & -- & -- \\
\hline Diethyl phthalate & -- & - & -- & -- & -- & - & -- & -- & -- & -- \\
\hline Dimethyl phthalate & - & -- & - & -- & -- & -- & -- & -- & - & -- \\
\hline 4,6-Dinitro-o-cresol & -- & -- & -- & -- & -- & -- & -- & -- & -- & - \\
\hline 2,4-Dinitrophenol & -- & -- & -- & -- & -- & -- & -- & -- & -- & -- \\
\hline 2,4-Dinitrotoluene & -- & -- & -- & - & -- & -- & -- & - & -- & -- \\
\hline 2,6-Dinitrotoluene & -- & -- & -- & -- & - & -- & -- & - & -- & -- \\
\hline Di-n-octyl phthalate & - & -- & -- & -- & -- & -- & -- & -- & -- & -- \\
\hline Fluoranthene & -- & -- & - & -- & - & -- & - & -- & - & -- \\
\hline Fluorene & -- & -- & -- & -- & -- & -- & -- & - & -- & - \\
\hline Hexachlorobenzene & -- & -- & - & -- & -- & -- & -- & -- & -- & - \\
\hline Hexachlorobutadiene & -- & -- & -- & -- & -- & -- & -- & -- & - & -- \\
\hline Hexachlorocyclopentadiene & - & -- & -- & -- & -- & -- & -- & -- & -- & -- \\
\hline Hexachloroethane & -- & -- & -- & -- & -- & -- & -- & -- & -- & -- \\
\hline Indeno (1,2,3-cd) pyrene & -- & -- & - & -- & -- & -- & -- & -- & $\cdots$ & -- \\
\hline Isophorone & -- & -- & -- & -- & -- & -- & -- & -- & -- & -- \\
\hline Naphthalene & -- & -- & -- & -- & -- & -- & -- & -- & -- & - \\
\hline Nitrobenzene & -- & -- & -- & -- & -- & -- & - & -- & -- & -- \\
\hline 2-Nitrophenol & -- & - & -- & -- & -- & -- & -- & -- & -- & -- \\
\hline 4-Nitrophenol & -- & -- & -- & -- & -- & -- & -- & -- & - & -- \\
\hline n-Nitrosodiphenylamine & - & -- & -- & - & -- & -- & - & -- & $2.59 \mathrm{~J} / 2.71 \mathrm{~J} / 1.69 \mathrm{~J}$ & - \\
\hline n-Nitrosodipropylamine & -- & -- & -- & -- & -- & -- & -- & - & -- & -- \\
\hline
\end{tabular}


ANAL YTICAL DATA SUMMARY

WELL CLUSTER AOB

\begin{tabular}{|c|c|c|c|c|c|c|c|c|c|c|}
\hline $\begin{array}{lr} & \begin{array}{r}\text { Well ID: } \\
\text { Date: } \\
\text { Analyte }\end{array} \\
\end{array}$ & $\begin{array}{c}\text { AOB 1,cont. } \\
10 / 23 / 93\end{array}$ & 2/12/94 & $7 / 8 / 94$ & 11/1/94 & $\begin{array}{c}\text { AOB2 } \\
1 / 20 / 91\end{array}$ & $4 / 22 / 91$ & $8 / 4 / 91$ & $11 / 13 / 91$ & $2 / 16 / 92$ & $5 / 25 / 92$ \\
\hline Pentachlorophenol & -- & -- & -- & -- & -- & -- & - & -- & -- & -- \\
\hline Phenanthrene & -- & -- & -- & -- & - & -- & -- & -- & -- & -- \\
\hline Phenol & -- & -- & -- & -- & -- & -- & -- & -- & -- & -- \\
\hline Pyrenc & - & -- & -- & -- & - & -- & -- & -- & $11 \mathrm{~J}$ & -- \\
\hline 1,2-Diphenylhydrazine & -- & -- & -- & -- & - & -- & -- & -- & $\cdots$ & -- \\
\hline 2-Methyl-4,6-dinitrophenol & -- & -- & - & -- & -- & -- & -- & -- & -- & -- \\
\hline \multicolumn{11}{|l|}{ Herbicides (SW8150) $(\mu g / L)$} \\
\hline 2,4,5-TP (Silvex) & - & -- & -- & -- & -- & -- & -- & -- & -- & -- \\
\hline 2,4-Dichlorophenoxyacetic acid (2,4-D) & -- & -- & -- & -- & -- & -- & -- & -- & $\cdots$ & -- \\
\hline \multicolumn{11}{|l|}{ Pesticides (SW8080) $(\mu \mathrm{g} / \mathrm{L})$} \\
\hline Aldrin & -- & -- & -- & -- & -- & -- & -- & -- & $\cdots$ & $-\cdot$ \\
\hline Chlordane & -- & -- & -- & -- & -- & -- & -- & -- & -- & -- \\
\hline p,p'-DDD & -- & -- & -- & -- & -- & -- & -- & -- & -- & -- \\
\hline p,p'-DDE & -- & -- & -- & -- & -- & -- & -- & -- & -- & -- \\
\hline p,p'-DDT & -- & -- & -- & - & -- & -- & -- & - & -- & -- \\
\hline Dieldrin & -- & -- & -- & -- & -- & -- & -- & -- & $\cdots$ & -- \\
\hline Endosulfan I & -- & -- & - & -- & -- & -- & -- & -- & $\cdots$ & - \\
\hline Endosulfan II & -- & -- & -- & -- & -- & -- & -- & -- & -- & -- \\
\hline Endosulfan sulfate & -- & -- & -- & -- & -- & -- & -- & $-\cdot$ & -- & -- \\
\hline Endrin & -- & -- & - & -- & -- & -- & -- & -- & -- & -- \\
\hline Endrin aldehyde & -- & -- & -- & -- & -- & - & -- & -- & -- & -- \\
\hline Heptachlor & $\cdots$ & -- & -- & -- & -- & -- & -- & -- & -- & -- \\
\hline Heptachlor epoxide & - & -- & -- & -- & -- & -- & -- & -- & -- & -- \\
\hline Lindane & - & -- & -- & -- & -- & -- & -- & -- & -- & - \\
\hline Toxaphene & -- & -- & - & -- & -- & -- & -- & -- & -- & -- \\
\hline
\end{tabular}

Note: Data qualifiers in table are those 1 
ANALYTICAL DATA SUMMARY

WELL CLUSTER AOB

\begin{tabular}{|c|c|c|c|c|c|c|c|c|c|c|c|c|}
\hline $\begin{array}{lr}\text { Well ID: } \\
\text { Date: } \\
\text { Analyte } & \\
\end{array}$ & $7 / 14 / 92$ & $\begin{array}{l}\text { AOB 2, c } \\
11 / 7 / 92\end{array}$ & $1 / 23 / 93$ & $4 / 17 / 93$ & 7/3/93 & $10 / 23 / 93$ & $2 / 12 / 94$ & $4 / 11 / 94$ & $7 / 8 / 94$ & $\begin{array}{l}\text { AOB } 3 \\
1 / 20 / 91\end{array}$ & $8 / 4 / 91$ & $11 / 15 / 91$ \\
\hline \multicolumn{13}{|l|}{ Metals $(\mu g / L)$} \\
\hline Aluminum, total recoverable & -- & -- & -- & -- & -- & -- & -- & -- & - & -- & -- & -- \\
\hline Antimony, dissolved & -- & -- & - & - & - & -- & -- & -- & $\cdots$ & -- & -- & - \\
\hline Antimony, total recoverable & -- & 5.5 & - & -- & -- & -- & - & -- & -- & -- & -- & -- \\
\hline Arsenic, dissolved & -- & -- & -- & -- & -- & -- & -- & -- & -- & -- & -- & -- \\
\hline Barium, dissolved & -- & $\cdots$ & -- & - & -- & -- & -- & - & -- & 7.4 & -- & 4.06 \\
\hline Barium, total recovcrable & -- & -- & - & -- & -- & -- & -- & -- & 3.21 & -- & -- & -- \\
\hline Cadmium, dissolved & -- & -- & -- & -- & -- & -- & -- & -- & -- & -- & - & -- \\
\hline Calcium, dissolved & -- & -- & -- & - & $\sim$ & -- & -- & - & -- & 11000 & -- & -- \\
\hline Calcium, total recoverable & -- & -- & 410 & -- & -- & -- & -- & -- & -- & -- & -- & -- \\
\hline Chromium, dissolved & -- & -- & -- & - & -- & -- & -- & -- & -- & -- & -- & -- \\
\hline Chromium, total recoverable & -- & 5.4 & -- & -- & -- & -- & -- & - & -- & -- & -- & - \\
\hline Cobalt, dissolved & -- & $\cdots$ & -- & -- & -- & -- & -- & -- & -- & -- & -- & - \\
\hline Copper, dissolved & 6.94 & -- & -- & -- & -- & -- & -- & -- & -- & -- & -- & -- \\
\hline Copper, total recoverable & - & 28.3 & -- & -- & -- & -- & -- & -- & 12.4 & -- & - & - \\
\hline Iron, dissolved & 18.2 & -- & -- & -- & -- & -- & -- & -- & -- & 46 & -- & -- \\
\hline Iron, total recoverable & -- & 253 & 27.9 & -- & 23.8 & - & $322 / 120$ & -- & 30.4 & -- & $\cdots$ & -- \\
\hline Lead, dissolved & 6.24 & -- & - & -- & -- & -- & -- & -- & -- & 5 & -- & -- \\
\hline Lead, total recoverable & -- & 6.17 & 5.23 & -- & -- & -- & -- & -- & 6.52 & - & -- & -- \\
\hline Magnesium, dissolved & -- & -- & -- & -- & -- & -- & -- & -- & -- & 390 & -- & -- \\
\hline Magnesium, total recoverable & -- & -- & 221 & -- & -- & - & -- & -- & -- & -- & -- & -- \\
\hline Manganese, dissolved & 5.33 & -- & -- & - & -- & -- & -- & -- & -- & 5.7 & -- & - \\
\hline Manganese, total recoverable & -- & 4.35 & 3.48 & -- & -- & -- & -- & -- & -- & -- & -- & -- \\
\hline Mercury, dissolved & -- & -- & -- & - & -- & -- & -- & -- & -- & -- & -- & -- \\
\hline Nickel, dissolved & 4.91 & -- & -- & - & -- & -- & -- & - & -- & -- & -- & -- \\
\hline Nickel, total recoverable & -- & 10.8 & -- & - & -- & -- & -- & -- & 8.98 & -- & -- & -- \\
\hline Selenium, dissolved & -- & -- & -- & - & -- & -- & - & -- & -- & -- & -- & -- \\
\hline Silica, dissolved & -- & -- & -- & -- & -- & -- & -- & -- & -- & 7400 & -- & -- \\
\hline Silica, total recoverable & - & - & 7330 & -- & -- & -- & - & -- & -- & -- & -- & - \\
\hline Silver, dissolved & - & -- & -- & -- & -- & - & -- & -- & - & -- & -- & -- \\
\hline Sodium, dissolved & 2230 & -- & -- & -- & -- & -- & -- & -- & -- & 1800 & -- & -- \\
\hline Sodium, total recoverable & - & 2420 & 2430 & -- & -- & -- & -- & -- & -- & -- & -- & -- \\
\hline Thallium, dissolved & -- & -- & -- & -- & -- & -- & $\cdots$ & -- & -- & -- & -- & -- \\
\hline Tin, dissolved & -- & -- & - & -- & -- & -- & -- & -- & - & -- & -- & -- \\
\hline
\end{tabular}

I:728475DATAIWELLDATA.XIS:sonted aob 
ANALYTICAL DATA SUMMARY

WELL CLUSTER AOB

\begin{tabular}{|c|c|c|c|c|c|c|c|c|c|c|c|c|}
\hline $\begin{array}{r}\text { Well ID: } \\
\text { Date: }\end{array}$ & $7 / 14 / 92$ & $\begin{array}{c}\text { AOB 2, c } \\
11 / 7 / 92\end{array}$ & $\begin{array}{l}\text { ont. } \\
1 / 23 / 93\end{array}$ & $4 / 17 / 93$ & $7 / 3 / 93$ & $10 / 23 / 93$ & $2 / 12 / 94$ & $4 / 11 / 94$ & $7 / 8 / 94$ & $\begin{array}{c}\text { AOB 3 } \\
1 / 20 / 91\end{array}$ & $8 / 4 / 91$ & $11 / 15 / 91$ \\
\hline Tin, total recoverable & - & 5.8 & - & $\ldots$ & - & -- & - & - & $\ldots$ & - & - & -- \\
\hline Vanadium, dissolved & - & -. & -- & -- & -- & -- & -- & - & - & -- & .- & -- \\
\hline Zinc, dissolved & 19.5 & -- & -- & -- & -- & -- & -- & -- & -- & -- & - & 6.35 \\
\hline Zinc, total recoverable & -- & 16.2 & -- & -- & -- & -- & -- & -- & 42.7 & -+ & -- & -- \\
\hline \multicolumn{13}{|l|}{ Inorganies } \\
\hline Chloride $(\mathrm{mg} / \mathrm{L})$ & 1.59 & 2.44 & 1.53 & -- & -- & -- & -- & -- & -. & 2.13 & -- & -- \\
\hline Cyanide $(\mu \mathrm{g} / \mathrm{L})$ & -- & -- & -- & - & -. & -- & -- & -- & -- & -- & -- & -- \\
\hline Fluoride (mg/L) & -- & -- & -- & -- & -- & -- & -- & -- & -- & - & -- & -- \\
\hline Nitrate as nitrogen $(\mathrm{mg} / \mathrm{L})$ & -- & 2.72 & -- & -- & -- & -- & -- & -- & -- & 0.46 & -- & -- \\
\hline Nitrate-nitrite as nitrogen $(\mathrm{mg} / \mathrm{L})$ & 0.86 & 0.9 & 0.91 & -- & -- & - & -- & -- & -- & -- & - & -- \\
\hline Sulfate $(\mathrm{mg} / \mathrm{L})$ & -- & 0.67 & -- & -- & -- & -- & -- & -- & -- & -- & -- & - \\
\hline Total phosphates (as P) $(\mathrm{mg} / \mathrm{L})$ & -- & -- & 0.07 & -- & -- & -- & -- & -- & - & -- & -- & -- \\
\hline \multicolumn{13}{|l|}{ General Chemistry } \\
\hline pH (std units) & -- & -- & $5.58 / 5.56$ & 5.43 & 5.69 & 5.79 & -- & -- & -- & 5.74 &.- & -. \\
\hline Specific conductance $(\mu \mathrm{S} / \mathrm{cm})$ & -- &.- & 20 & 20 & $20 / 18$ & 21 & -- & -- & -- & 20 & -- & -- \\
\hline Total dissolved solids (mg/L) & -- & -- & 24 & $8 / 6$ & 21 & 5 & -- & -- & -- & 46 & -- & -- \\
\hline Oil \& grease & 10 & 7.7 & -- & 2.4 & -- & 2.65 & -- & 23.7 & -- & -- & -- & - \\
\hline Phenols $(\mu \mathrm{g} / \mathrm{L})$ & -- & -- & -- & -- & -- & -- & -- & - & - & -- & -- & -- \\
\hline Total organic carbon $(\mathrm{mg} / \mathrm{L})$ & -- & -- & -- & -- & -- & -- & -- & -- & -. & -- & -- & $\cdots$ \\
\hline Total organic halogens $(\mu \mathrm{g} / \mathrm{L})$ & -- & 14.6 & 10.7 & -- & -- & -- & 9.4 & -- & 21.6 & -- & -- & -- \\
\hline Total Petroleum Hydrocarbons & -- & 16.2 & -- & -- & -- & -- & -- & -- & -- & - & -- & -- \\
\hline \multicolumn{13}{|l|}{ Radioactivity } \\
\hline Gross alpha (pCi/L) & -- & 1 & -- & -- & -- & -- & -- & -- & 0.532 & 2.4 & - & 4.47 \\
\hline Nonvolatile beta (pCi/L) & -- & 1.2 & -- & -. & -- & -- & -- & -- & 0.384 & 2 & -- & -- \\
\hline Total activity (PCML) & -- & -- & -- & -- & -- & -- & -- & -- & $\cdots$ & -- & -- & -- \\
\hline Radium, total alpha-emitting (pCi/L) & -- & 1.3 & 1.2 & -- & -- & -- & -- & -- & -- & 2.8 & 5.6 & -- \\
\hline Uranium alpha activity $(\mathrm{pCi} / \mathrm{L})$ & -- & -- & -- & -- & -- & -- & -- & $\cdots$ & -- & -- & - & -- \\
\hline Antimony-125 & -- & -- & -- & -- & -- & -- & -- & -- & -- & -- & -- & - \\
\hline Cerium-144 & -- & - & -- & -- & -- & -- & - & -- & -- & - & - & -- \\
\hline Cesium-134 & -- & - & -- & -- & -- & -- & -- & -- & -- & -- & -- & - \\
\hline Cesium-137 & -- & -- & -- & -- & -- & -- & -- & -- & -- & -- & -- & -- \\
\hline
\end{tabular}


NALYTICAL DATA SUMMARY

WELL CLUSTER AOB

\begin{tabular}{|c|c|c|c|c|c|c|c|c|c|c|c|c|c|}
\hline \multicolumn{2}{|r|}{$\begin{array}{r}\text { Well ID: } \\
\text { Date: }\end{array}$} & $7 / 14 / 92$ & $\begin{array}{l}\text { AOB 2, co } \\
11 / 7 / 92\end{array}$ & $1 / 23 / 93$ & $4 / 17 / 93$ & $7 / 3 / 93$ & $10 / 23 / 93$ & $2 / 12 / 94$ & $4 / 11 / 94$ & $7 / 8 / 94$ & $\begin{array}{c}\text { AOB 3 } \\
1 / 20 / 91\end{array}$ & $8 / 4 / 91$ & $11 / 15 / 91$ \\
\hline Cobalt-57 & & -- & -- & -- & -- & -- & -- & $\overline{--}$ & - & -. & -- & -- & -- \\
\hline Cobalt- 60 & & -- & -- & - & -- & -- & -- & -- & -- & -. & -- & -- & -- \\
\hline Europium-154 & & -- & -- & -- & -- & -- & -- & -- & -- & -- & -- & $\ldots$ & -- \\
\hline Europium-155 & & -- & -- & -- & -- & -- & -- & -- & -- & -- & -- & -- & -- \\
\hline Manganese-54 & & -- & -- & -- & -- & -- & -- & -- & -- & -- & -- & -- & -- \\
\hline Neptunium-237 & & -- & -- & -- & -- & -- & -- & -- & -- & - & -- & -- & -- \\
\hline Potassium-40 & . & -- & -- & -- & -- & -- & -- & -- & -- & -- & -- & -- & -- \\
\hline Promethium-144 & & -- & - & -- & -- & -- & -- & -- & -- & -- & -- & -- & -- \\
\hline Promethium-146 & & -- & - & -- & -- & -- & -- & -- & -- & -- & -- & -- & -- \\
\hline Radium-226 (pCi/L) & & -- & 0.58 & -- & -- & -- & -- & -- & -- & -- & -- & -- & -- \\
\hline Radium-228 (pCi/L) & & -- & -- & -- & -- & -- & -- & -- & - & -- & -- & - & $\cdots$ \\
\hline Ruthenium-103 & & -- & -- & -- & -- & -- & -- & -- & -- & -- & -- & -- & -- \\
\hline Sodium-22 & & -- & - & -- & -- & -- & -- & -- & -- & -- & -- & $\cdots$ & $\cdots$ \\
\hline Thorium-228 & & -- & -- & -- & -- & -- & -- & -- & -- & -- & -- & -- & -- \\
\hline Tritium (PCML) & & 1.22 & -- & 0.722 & - & -- & - & -- & -- & -- & 1.75 & -- & 2.06 \\
\hline Tritium (pCi/L) & & -- & 1703.54 & -- & -- & -- & -- & -- & -- & -- & -- & -- & -- \\
\hline Uranium-233/234 (pCi/L) & & -- & -- & -- & -- & - & -- & - & -- & -- & -- & -- & -- \\
\hline Uranium-234 (pCi/L) & & -- & - & -- & -- & -- & -- & -- & -- & -- & -- & $\cdots$ & -- \\
\hline Uranium-235 (pCi/L) & & -- & -- & -- & -- & -- & -- & -- & -- & -- & -- & -- & -- \\
\hline Uranium-238 (pCi/L) & & -- & -- & -- & -- & - & -- & -- & -- & -- & -- & -- & -- \\
\hline Zinc-65 & & - & -- & -- & -- & -- & -- & -- & -- & -- & -- & -- & - \\
\hline \multicolumn{14}{|c|}{ Volatile Organics (SW8240) $(\mu \mathrm{g} / \mathrm{L})$} \\
\hline 1,1,1-Trichloroethane & & -- & -- & -- & -- & -- & -- & -- & -- & -- & -- & -- & -- \\
\hline 1,1,2,2-Tetrachloroethane & & -- & -- & -- & -- & -- & -- & -- & -- & -- & -- & -- & -- \\
\hline 1,1,2-Trichloroethane & & -- & -- & -- & -- & - & -- & -- & -- & -- & -- & -- & $\cdots$ \\
\hline 1,1-Dichloroethane & & -- & -- & -- & -- & -- & -- & -- & -- & $\cdots$ & -- & -- & -- \\
\hline 1,1-Dichloroethylene & & - & -- & -- & - & -- & -- & -- & -- & -- & -- & - & -- \\
\hline 1,2-Dichloroethane & & -- & -- & -- & -- & - & -- & -- & -- & - & -- & -- & -- \\
\hline 1,2-Dichloropropane & & -- & -- & -- & -- & -- & -- & -- & -- & -- & -- & - & - \\
\hline 2-Chloroethyl vinyl ether & & -- & -- & -- & -- & -- & -- & -- & -- & -- & -- & -- & -- \\
\hline Benzene & & -- & -- & -- & -- & -- & -- & -- & -- & -- & -- & -- & -- \\
\hline Bromodichloromethane & & -- & -- & -- & -- & -- & -- & -- & -- & -- & -- & -- & -- \\
\hline
\end{tabular}

I:\728475DATAIWELLDATA.XIS:soned aob 
ANALYTICAL DATA SUMMARY

WELL CLUSTER AOB

\begin{tabular}{|c|c|c|c|c|c|c|c|c|c|c|c|c|}
\hline $\begin{array}{lr} & \begin{array}{r}\text { Well ID: } \\
\text { Date: }\end{array} \\
\text { Analyte } & \\
\end{array}$ & $7 / 14 / 92$ & $\begin{array}{l}\text { AOB 2, cc } \\
11 / 7 / 92\end{array}$ & $\begin{array}{l}\text { nt. } \\
1 / 23 / 93\end{array}$ & $4 / 17 / 93$ & 7/3/93 & $10 / 23 / 93$ & $2 / 12 / 94$ & $4 / 11 / 94$ & 7/8/94 & $\begin{array}{c}\text { AOB 3 } \\
1 / 20 / 91\end{array}$ & $8 / 4 / 91$ & $11 / 15 / 91$ \\
\hline Bromoform & -- & $\overline{--}$ & -- & -- & -- & -- & -. & -- & -- & -- & -- & -- \\
\hline Bromomethane (Methyl bromide) & -- & -- & -- & -- & -- & -- & -- & -- & -- & -- & -- & -- \\
\hline Carbon tetrachloride & -- & -- & -- & -- & -- & -- & -- & - & -- & -- & -- & -- \\
\hline Chlorobenzene & -- & -- & -- & -- & -- & -- & -- & -- & -- & -- & -- & -- \\
\hline Chloroethane & -- & -- & - & -- & -- & -- & -- & -- & - & -- & -- & -- \\
\hline Chloroform & -- & -- & -- & -- & -- & -. & -- & -- & 1.3 & -- & $-\cdot$ & -- \\
\hline Chloromethane (Methyl chloride) & -- & -- & -- & -- & -- & -- & -- & -- & -- & -- & -. & -- \\
\hline cis-1,3-Dichloropropene & -- & -- & -- & -- & -- & -- & -- & -- & -- & -- & -- & -- \\
\hline Dibromochloromethane & -- & -- & -- & -- & -- & -- & -- & -- & -- & -- & -- & -- \\
\hline Ethylbenzene & 1.14 & -- & -- & - & -- & -- & - & 1.5 & 1.1 & -- & -- & -- \\
\hline Methylene chloride (Dichloromethane) & $6.73 \mathrm{~J}$ & - & -- & -- & -- & $2.3 / 2$ & 3.22 & -- & -- & -- & - & 5.6 \\
\hline Tetrachloroethylene & -- & -- & -- & -- & - & -- & -- & -- & -- & $-\cdot$ & -- & -- \\
\hline Toluene & 4.41 & 1.7 & -- & 1.8 & -- & -- & 2.6 & 6 & 4.3 & -- & -- & 1.4 \\
\hline trans-1,2-Dichloroethylene & -- & -- & -- & -- & -- & -- & -- & -- & - & -- & -- & $\cdot \cdot$ \\
\hline trans-1,3-Dichloropropene & - & -- & -- & -- & -- & -- & -- & -- & -- & -- & -- & -- \\
\hline Trichloroethylene & -- & -- & - & . -- & -- & - & -- & -. & -- & -- & $-\cdot$ & -- \\
\hline Trichlorofluoromethane & -- & -- & -- & -- & -- & -- & -- & -- & -- & -- & -- & $-\cdot$ \\
\hline Vinyl chloride (Chloroethene) & -- & -- & -- & -- & -- & -- & -- & -- & -- & -- & -- & -- \\
\hline Xylenes & 7.75 & 2.04 & -- & -- & -- & -- & -- & -- & -- & -- & -- & -- \\
\hline \multicolumn{13}{|l|}{ Semivolatile Organics (SW8270) } \\
\hline Acenaphthene & - & -- & -- & -- & -- & -- & -- & -. & -- & -- & -- & -- \\
\hline Acenaphthylene & -- & -- & -- & -- & -- & -- & -- & -- & -- & -- & -- & $\cdots$ \\
\hline Anthracene & -- & -- & -- & -- & -- & -- & -- & -- & -- & -- & -- & $\cdots$ \\
\hline Benzidine & -- & - & -- & - & -- & -- & -- & -- & - & -- & -- & -- \\
\hline Benzo(a)anthracene & -- & -- & -- & -- & -- & -- & -- & -- & -- & -- & -- & -- \\
\hline Benzo(b)fluoranthene & -- & -. & -- & -- & -- & -- & -- & -- & -- & -- & -- & -- \\
\hline Benzo(g,h,i)perylene & -- & -- & -- & -- & -- & -- & -- & - & -- & -- & -- & -- \\
\hline Benzo(a)pyrene & -- & -- & -- & -- & -. & -- & -- & -- & $\cdots$ & -- & -- & -- \\
\hline Benzo(k)fluoranthene & -- & -- & - & -- & -- & -- & -- & -- & -- & -- & -- & -- \\
\hline bis(2-Chloroethoxy) methane & -- & -- & - & -- & -- & -- & -- & -- & -- & -- & -- & -- \\
\hline bis(2-Chloroethyl) ether & -- & -- & -- & - & -- & -- & -- & -- & -- & -- & -- & -- \\
\hline bis(2-Chloroisopropyl) ether & -- & -- & -- & -- & -- & -- & - & -- & -- & -- & -- & -- \\
\hline
\end{tabular}


ANALYTICAL DATA SUMMARY

WELL CLUSTER AOB

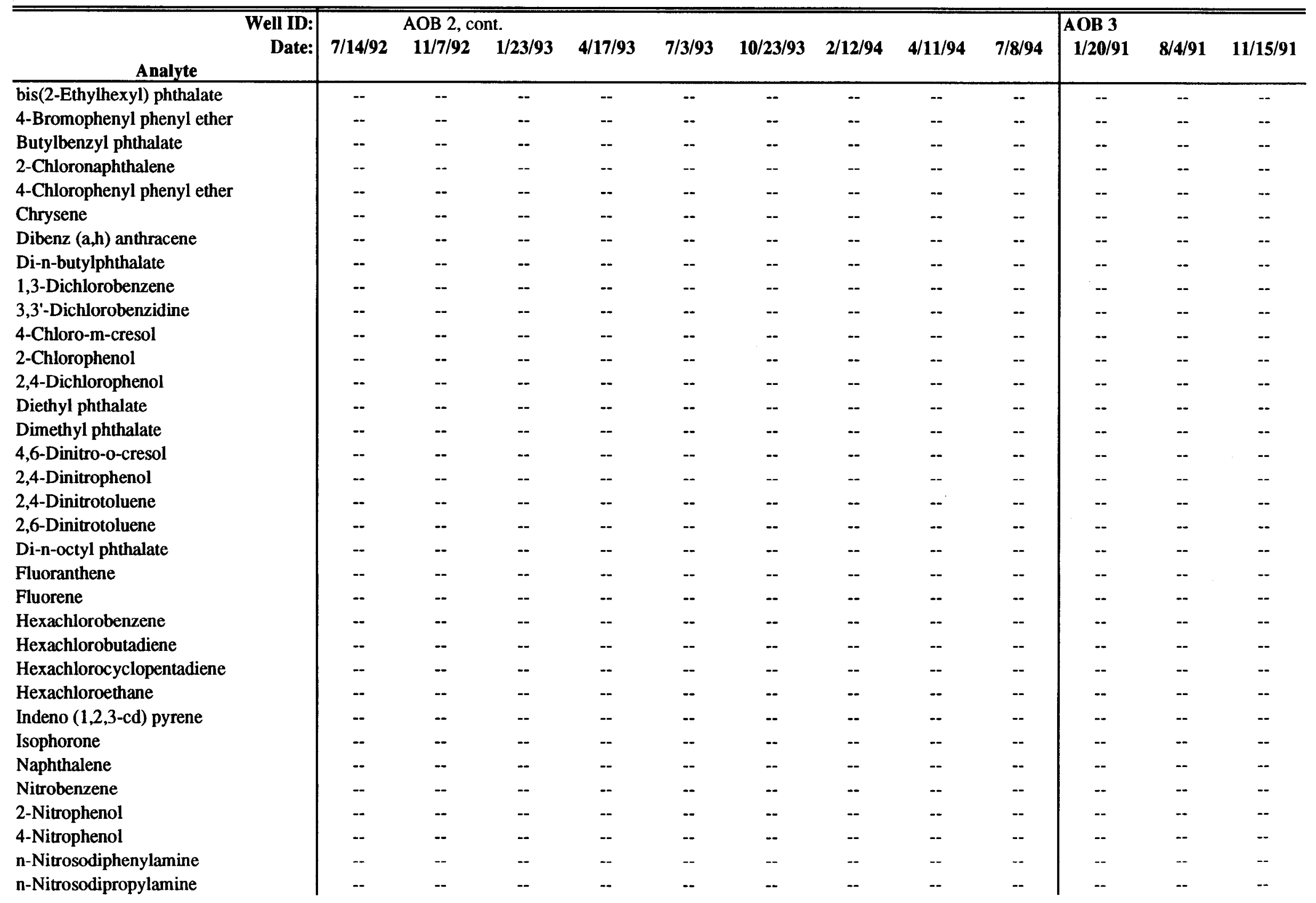

I:1728475DATAIWELLDATA.XLS:sorted aob 
ANALYTICAL DATA SUMMARY

WELL CLUSTER AOB

\begin{tabular}{|c|c|c|c|c|c|c|c|c|c|c|c|c|}
\hline $\begin{array}{r}\text { Well ID: } \\
\text { Date: }\end{array}$ & $7 / 14 / 92$ & $\begin{array}{c}\text { AOB } 2, \mathrm{cc} \\
11 / 7 / 92\end{array}$ & $1 / 23 / 93$ & $4 / 17 / 93$ & 7/3/93 & $10 / 23 / 93$ & $2 / 12 / 94$ & $4 / 11 / 94$ & $7 / 8 / 94$ & $\begin{array}{c}\text { AOB 3 } \\
1 / 20 / 91\end{array}$ & $8 / 4 / 91$ & $11 / 15 / 91$ \\
\hline Pentachlorophenol & -- & -- & -- & -- & -- & -- & -- & -- & $\ldots$ & -- & - & - \\
\hline Phenanthrene & -- & -- & -- & -- & -- & -- & -- & -- & -- & -- & -- & -- \\
\hline Phenol & - & -- & - & -- & -- & -- & -- & -- & -- & -- & -- & -- \\
\hline Pyrene & -- & -- & -- & -- & -- & -- & -- & -- & -- & -- & -- & -- \\
\hline 1,2-Diphenylhydrazine & -- & -- & -- & -- & -- & -- & -- & -- & -- &.- & - & -- \\
\hline 2-Methyl-4,6-dinitrophenol & - & -- & -- & -- & -- & -- & -- & -- & -- & -- & -- & -- \\
\hline \multicolumn{13}{|l|}{ Herbicides (SW8150) $(\mu \mathrm{g} / \mathrm{L})$} \\
\hline 2,4,5-TP (Silvex) & -- & -- & -- & -- & -- & -- & -- & -- & -- & -- & -- & -- \\
\hline 2,4-Dichlorophenoxyacetic acid (2,4-D) & -- & - & -- & -- & -- & -- & - & -- & -- & $\cdots$ & -- & -- \\
\hline \multicolumn{13}{|l|}{ Pesticides (SW8080) $(\mu \mathrm{g} / \mathrm{L})$} \\
\hline Aldrin & -- & -- & -- & -- & -- & -- & -- & -- & -- & -- & -- & -- \\
\hline Chlordane & -- & -- & -- & -- & -- & -- & -- & -- & -- & - & -- & -- \\
\hline p,p'-DDD & -- & -- & -- & -- & - & -- & - & - & -- & -- & - & -- \\
\hline p,p'-DDE & -- & -- & -- & -- & -- & -- & -- & - & -- & -- & -- & - \\
\hline p,p'-DDT & -- & -- & -- & -- & -- & -- & -- & -- & -- & -- & -- & - \\
\hline Dieldrin & -- & -- & -- & -- & -- & -- & -- & -- & -- & -- & -- & -- \\
\hline Endosulfan I & -- & -- & -- & -- & -- & -- & $-\cdot$ & -- & -- & - & - & -- \\
\hline Endosulfan II & -- & -- & -- & -- & -- & -- & -- & -- & -- & -- & -- & -- \\
\hline Endosulfan sulfate & -- & -- & -- & -- & -- & -- & -- & -- & -- & -- & -- & -- \\
\hline Endrin & -- & -- & -- & -- & - & -- & -- & -- & -- & -- & -- & -- \\
\hline Endrin aldehyde & -- & -- & -- & -- & -- & -- & -- & -- & -- & -- & -- & -- \\
\hline Heptachlor & -- & -- & -- & $\cdots$ & -- & -- & -- & -- & -- & $\cdots$ & -- & -- \\
\hline Heptachlor epoxide & -- & -- & -- & -- & - & -- & -- & -- & -- & -- & -- & - \\
\hline Lindane & -- & -- & -- & -- & -- & -- & -- & -- & - & -- & -- & -- \\
\hline Toxaphene & -- & -- & -- & -- & -- & -- & $\cdots$ & -- & - & $\cdots$ & -- & - \\
\hline
\end{tabular}

Note: Data qualifiers in table are those 1 
ANAL YTICAL DATA SUMMARY

WELL CLUSTER AOB

\begin{tabular}{|c|c|c|c|c|c|c|c|c|c|c|c|}
\hline $\begin{array}{cr} & \begin{array}{r}\text { Well ID: } \\
\text { Date: } \\
\end{array} \\
\text { Analyte } & \\
\end{array}$ & 1/8/92 & $\begin{array}{c}\mathrm{AOB} \mathrm{3,c} \\
5 / 26 / 92\end{array}$ & $\begin{array}{l}\text { nt. } \\
7 / 14 / 92\end{array}$ & $11 / 7 / 92$ & $1 / 23 / 93$ & $4 / 18 / 93$ & 7/3/93 & $10 / 24 / 93$ & $2 / 13 / 94$ & $4 / 12 / 94$ & $7 / 8 / 94$ \\
\hline Metals $(\mu \mathrm{g} / \mathrm{L})$ & & & & & & & & & & & \\
\hline Aluminum, total recoverable & -- & -- & -- & -- & 339 & -- & 411 & -- & 269 & -. & 121 \\
\hline Antimony, dissolved & -- & -- & - & -- & -- & -- & -- & -- & -- & -- & -- \\
\hline Antimony, total recoverable & -- & -- & -- & - & -- & -- & -- & -- & -- & -- & -- \\
\hline Arsenic, dissolved & -- & - & -- & -- & -- & -- & - & -- & -- & -- & -- \\
\hline Barium, dissolved & 3.68 & 4.49 & 4.71 & -- & -- & -- & -- & -- & -- & -- & -- \\
\hline Barium, total recoverable & -- & -- & -- & 4.61 & 4.8 & -- & -- & -- & -- & -- & 4.18 \\
\hline Cadmium, dissolved & -- & -- & -- & -- & -- & -- & -- & -- & -- & -- & -- \\
\hline Calcium, dissolved & - & -- & -- & -- & -- & -- & -- & -- & -- & -- & -- \\
\hline Calcium, total recoverable & -- & - & -- & -- & 1680 & -- & -- & -- & -- & -- & -- \\
\hline Chromium, dissolved & -- & -- & -- & - & - & -- & -- & -- & -- & -- & -- \\
\hline Chromium, total recoverable & -- & -- & -- & -- & -- & -- & -. & -- & -- & -- & -- \\
\hline Cobalt, dissolved & -- & -- & -- & -- & -- & -- & -- & -- & -- & -- & -- \\
\hline Copper, dissolved & -- & -- & -- & -- & -- & -- & -- & -- & -- & -- & -- \\
\hline Copper, total recoverable & -- & -- & -- & -- & - & -- & -- & -- & -- & -- & -- \\
\hline Iron, dissolved & 111 & -- & 79 & -- & -- & -- & -- & -- & -- & -- &.- \\
\hline Iron, total recoverable & -- & -- & -- & 77.7 & 46.9 & -- & 73.3 & -- & 23.4 & -- & 54.1 \\
\hline Lead, dissolved & -- & -- & -- & -- & -- & -- & -- & -- & -- & -- & -- \\
\hline Lead, total recoverable & -- & -- & -- & -- & -- & -- & -- & -- & -- & -- & -- \\
\hline Magnesium, dissolved & -- & -- & -- & -- & -- & -- & -- & - & -. & $\ldots$ & -- \\
\hline Magnesium, total recoverable & -- & -- & -- & -- & 369 & -- & -- & -- & -- & -- & - \\
\hline Manganese, dissolved & 6.08 & 6.33 & 6.53 & -- & -- & -- & -- & -- & -- & -- & -- \\
\hline Manganese, total recoverable & -- & -- & -- & 5.86 & 6.27 & -- & -- & -- & -- & -- & -- \\
\hline Mercury, dissolved & -- & -- & -- & -- & -- & -- & -- & -- & -- & -- & -- \\
\hline Nickel, dissolved & -- & -- & -- & -- & -- & -- & -- & -- & -- & - & -- \\
\hline Nickel, total recoverable & -- & -- & -- & -- & -- & - & -- & -- & -- & -- & $-\infty$ \\
\hline Selenium, dissolved & -- & 2 & -- & -- & -- & -- &.- & -- & -- & -- & -- \\
\hline Silica, dissolved & - & -- & -- & -- & -- & -- & -- & -- & -- & -- & -- \\
\hline Silica, total recoverable & -- & -- & -- & -- & 7750 & -- & -- & -- & -- & -- & -- \\
\hline Silver, dissolved & - & -- & -- & -- & -- & -- & -- & -- & -- & -- & -- \\
\hline Sodium, dissolved & 1720 & 1720 & 1490 & -- & -- & -- & -- & - & -- & -- & -- \\
\hline Sodium, total recoverable & -- & - & -- & 1520 & 1690 & -- & -- & -- & -- & -- & -- \\
\hline Thallium, dissolved & -- & -- & -- & -- & -- & -- & -- & -- & -- & -- & - \\
\hline Tin, dissolved & -- & -- & -- & -- & -- & -- & -- & -- & -- & -- & -. \\
\hline
\end{tabular}


ANAL YTICAL DATA SUMMARY

WELL CLUSTER AOB

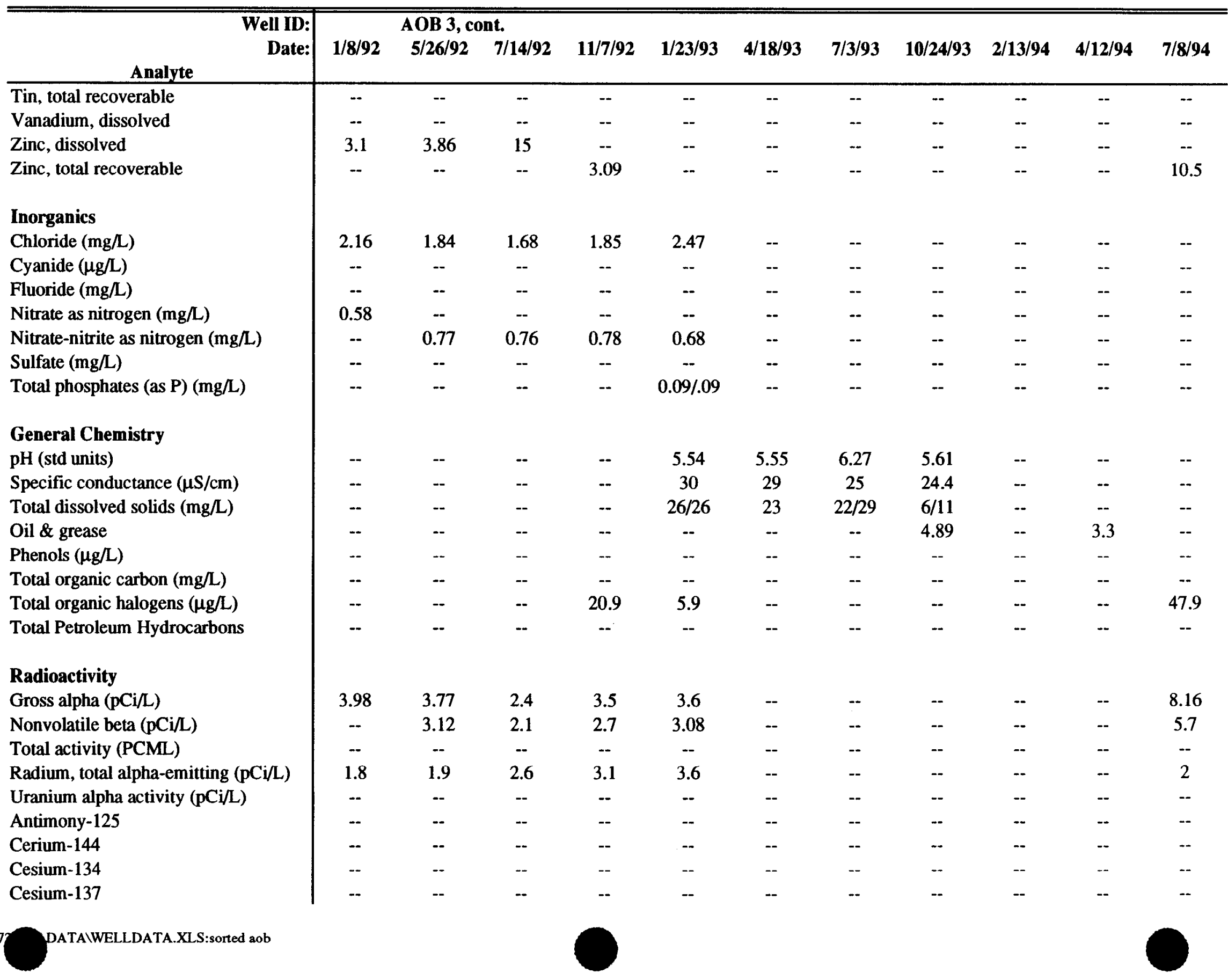


ANALYTICAL DATA SUMMARY

WELL CLUSTER AOB

\begin{tabular}{|c|c|c|c|c|c|c|c|c|c|c|c|}
\hline Well ID: & & $\overline{\mathrm{AOB}} 3, \mathrm{C}$ & & & & & & & & & \\
\hline $\begin{array}{ll} & \text { Date: } \\
\text { Analyte }\end{array}$ & 1/8/92 & $5 / 26 / 92$ & $7 / 14 / 92$ & $11 / 7 / 92$ & $1 / 23 / 93$ & $4 / 18 / 93$ & $7 / 3 / 93$ & $10 / 24 / 93$ & $2 / 13 / 94$ & $4 / 12 / 94$ & $7 / 8 / 94$ \\
\hline Cobalt-57 & - & $\overline{--}$ & - & -- & -- & -. & - & -- & -- & - & -- \\
\hline Cobalt -60 & -- & -- & -- & -- & -- & -- & -- & -- & -- & -- & -- \\
\hline Europium-154 & -- & -- & -- & -- & -- & -- & -- & -- & -- & -- & -- \\
\hline Europium-155 & -- & -- & -- & -- & -- & - & -- & -- & -- & -. & -- \\
\hline Manganese-54 & -- & -- & -- & -- & -- & - & -- & -- & -- & -- & -- \\
\hline Neptunium-237 & - & 75.3 & -- & -- & -- & -- & -- & -- & -- & -- & -- \\
\hline Potassium-40 & -- & - & -- & -- & -- & -- & -- & -- & -- & -- & $\ldots$ \\
\hline Promethium-144 & -- & -- & -- & -- & -- & -- & -- & -- & -- & -- & -- \\
\hline Promethium-146 & -- & -- & -- & -- & -- & -- & -- & -- & -- & -- & -- \\
\hline Radium-226 (pCi/L) & - & - & -- & -- & -- & -- & -- & -- & - & - & $\cdots$ \\
\hline Radium-228 (pCi/L) & -- & -- & -- & -- & -- & -- & - & -- & -- & -- & -- \\
\hline Ruthenium-103 & -- & -- & -- & -- & -- & -- & -- & -- & -- & -- & -- \\
\hline Sodium-22 & -- & -- & -- & -- & -- & -- & -- & -- & -- & -- & -- \\
\hline Thorium-228 & -- & -- & -- & -- & -- & -- & -- & -- & -- & -- & -- \\
\hline Tritium (PCML) & 0.774 & 1.28 & 1.67 & 0.989 & 1.06 & - & -- & - & -- & -- & -- \\
\hline Tritium (pCi/L) & -- & -- & -- & -- & -- & -- & - & -- & -- & -- & -- \\
\hline Uranium-233/234 (pCi/L) & -- & -- & -- & -- & -- & -- & -- & -- & -- & -- & -- \\
\hline Uranium-234 (pCi/L) & -- & -- & -- & -- & -- & -- & -- & -- & -- & -- & -- \\
\hline Uranium-235 (pCi/L) & -- & -- & -- & -- & -- & -- & -- & -- & -- & -- & -- \\
\hline Uranium-238 (pCi/L) & -- & -- & -- & $\ldots$ & -- & - & -- & -- & -- & -- & -- \\
\hline Zinc-65 & -- & -- & - & - & - & -- & - & -- & -- & -- & -- \\
\hline Volatile Organics (SW8240) $(\mu \mathrm{g} / \mathrm{L})$ & & & & & & & & & & & \\
\hline 1,1,1-Trichloroethane & -- & -- & -- & -- & -- & -- & -- & -- & -- & - & -- \\
\hline 1,1,2,2-Tetrachloroethane & -- & -- & -- & -- & -- & - & -- & -. & - & -- & -- \\
\hline 1,1,2-Trichloroethane & -- & -- & -- & -- & -- & - & -- & -- & -- & -- & -- \\
\hline 1,1-Dichloroethane & -- & -- & -- & -- & -- & -- & -- & -- & -- & -- & -- \\
\hline 1,1-Dichloroethylene & -- & -- & -- & -- & -- & -- & -- & -- & -- & -- & -- \\
\hline 1,2-Dichloroethane & -- & -- & -- & -- & -- & -- & -- & $\cdots$ & -. & -- & -- \\
\hline 1,2-Dichloropropane & -- & -- & -- & -- & -- & -- & -- & -- & -- & -- & -- \\
\hline 2-Chloroethyl vinyl ether & -- & -- & -- & -- & -- & -- & -- & -- & -- & -- & -- \\
\hline Benzene & -- & -- & -. & $\cdots$ & -- & -- & -. & -- & -- & -- & -- \\
\hline Bromodichloromethane & -- & -- & -- & -- & -- & -- & -- & -- & -- & - & -- \\
\hline
\end{tabular}

I:728475DATAIWELLDATA.XIS:sorted aob 
ANALYTICAL DATA SUMMARY

WELL CLUSTER AOB

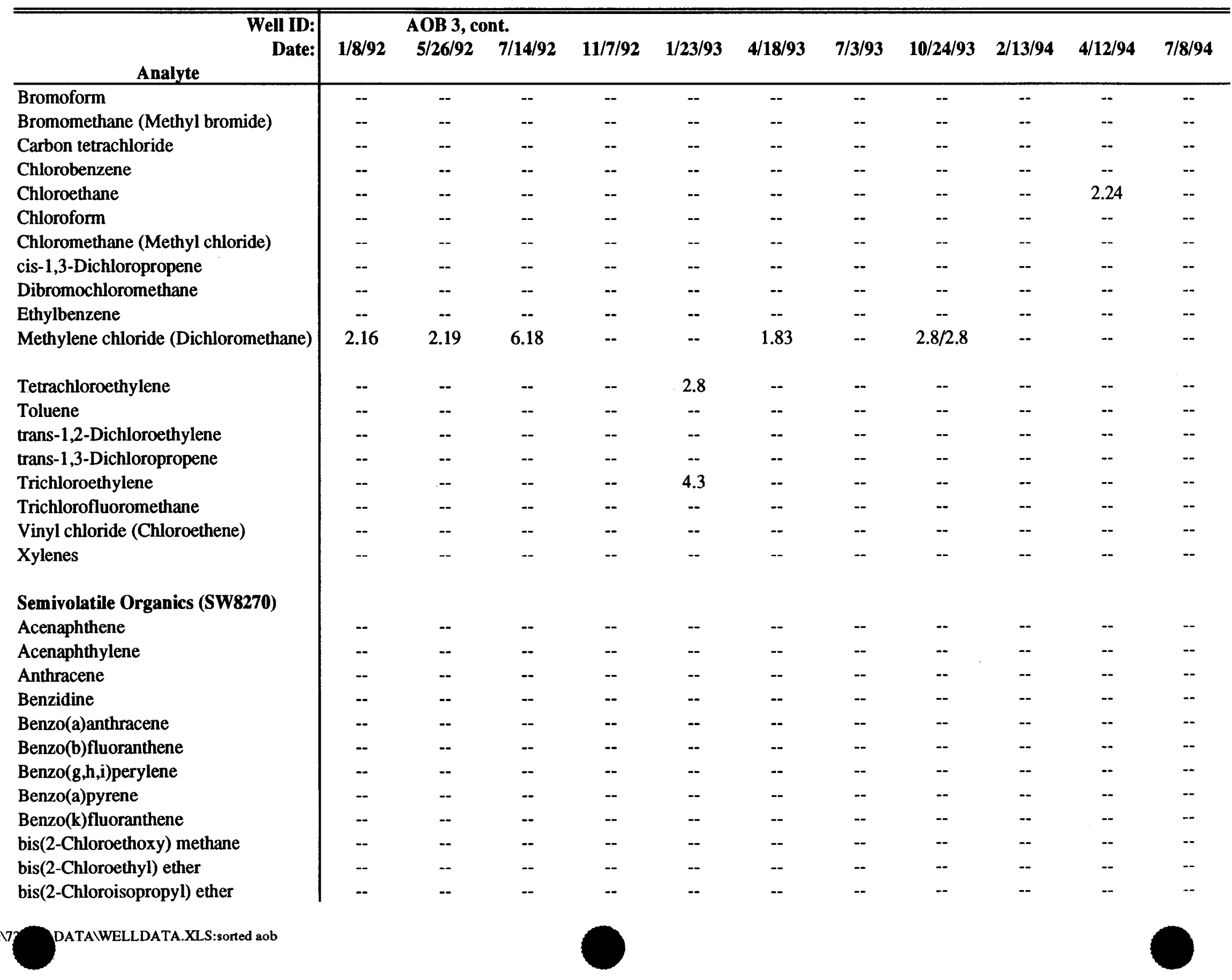


ANALYTICAL DATA SUMMARY

WELL CLUSTER AOB

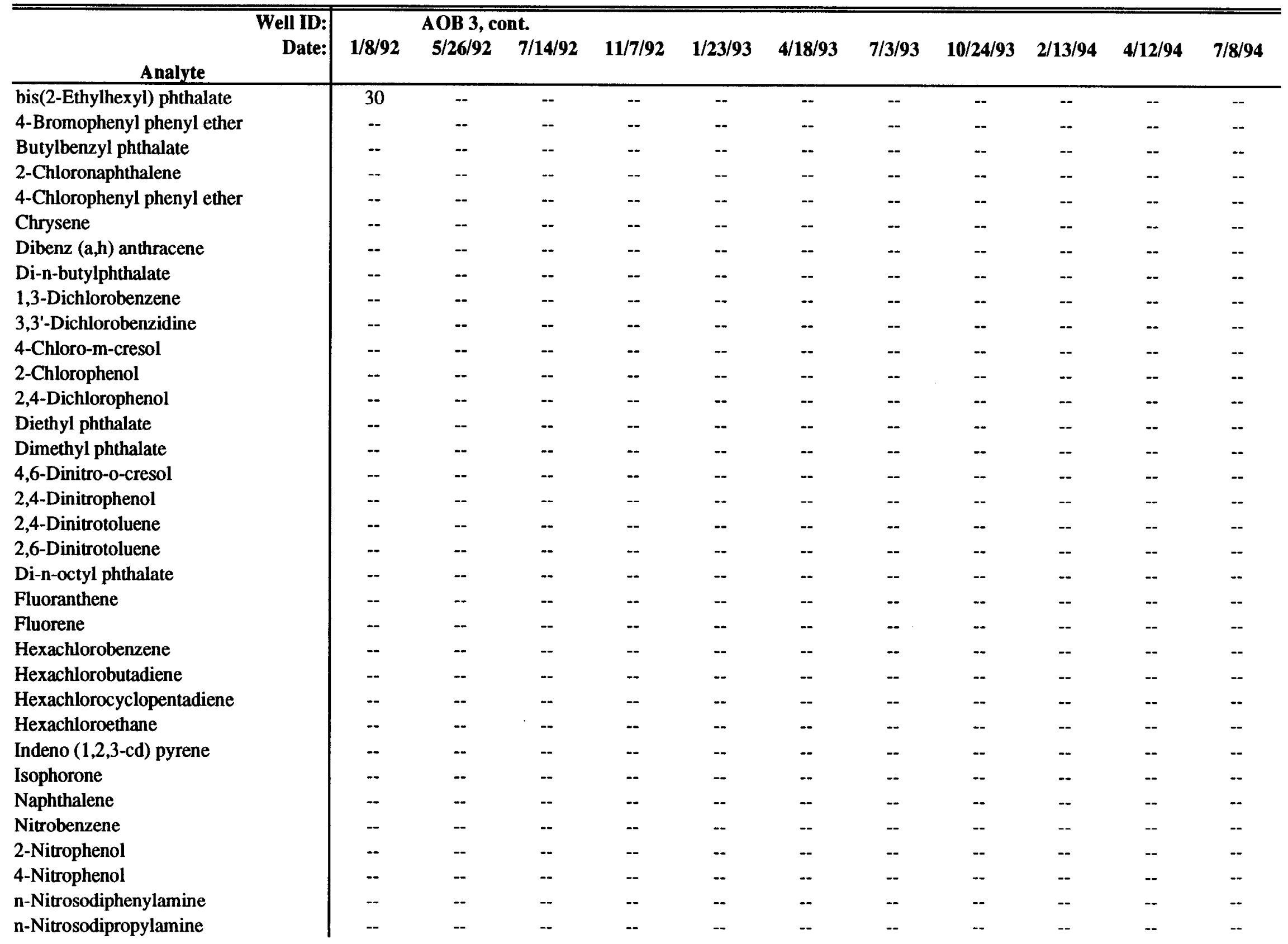


ANALYTICAL DATA SUMMARY

WELL CLUSTER AOB

\begin{tabular}{|c|c|c|c|c|c|c|c|c|c|c|c|}
\hline $\begin{array}{r}\text { Well ID: } \\
\text { Date: }\end{array}$ & $\mathbf{1} / \mathbf{8} / \mathbf{9 2}$ & $\begin{array}{c}\mathrm{AOB} \mathrm{3,} \\
5 / 26 / 92\end{array}$ & 7/14/92 & $11 / 7 / 92$ & $1 / 23 / 93$ & $4 / 18 / 93$ & $7 / 3 / 93$ & $10 / 24 / 93$ & $2 / 13 / 94$ & $4 / 12 / 94$ & $7 / 8 / 94$ \\
\hline Pentachlorophenol & - & -- & -- & -- & -- & -- & -- & -- & -- & -- & -- \\
\hline Phenanthrene & -- & -- & -- & -- & -. & -- & -- & -- & -- & -- & -- \\
\hline Phenol & -- & -- & -- & -- & -- & -- & -- & -- & -- & - & -- \\
\hline Pyrene & -- & -- & -- & -- & -- & -- & -- & -- & -- & -- & -- \\
\hline 1,2-Diphenylhydrazine & -- & -- & -- & -- & -- & -. & -- & -- & -- & -- & - \\
\hline 2-Methyl-4,6-dinitrophenol & -- & -- & -- & - & - & -- & -- & -- & -- & -- & -- \\
\hline \multicolumn{12}{|l|}{ Herbicides (SW8150) $(\mu \mathrm{g} / \mathrm{L})$} \\
\hline 2,4,5-TP (Silvex) & -- & -- & -- & -- & -- & -- & -- & -- & -- & -- & -- \\
\hline 2,4-Dichlorophenoxyacetic acid (2,4-D) & -- & -- & -- & -- & -- & -- & -- & -- & -- & $\cdots$ & -- \\
\hline \multicolumn{12}{|l|}{ Pesticides (SW8080) $(\mu g / L)$} \\
\hline Aldrin & -- & -- & -- & -- & -- & -- & -- & -- & -- & -- & -- \\
\hline Chlordane & -- & -- & -- & -- & -- & $\cdots$ & - & -- & -- & -- & $\ldots$ \\
\hline p,p'-DDD & -- & -- & -- & -- & -- & -- & -- & - & -- & -- & -- \\
\hline p,p'-DDE & -- & -- & -- & -- & -- & -- & -- & -- & -- & -- & -- \\
\hline p,p'-DDT & -- & -- & -- & -- & -- & -- & -- & -- & -- & -- & -- \\
\hline Dieldrin & -- & -- & -- & -- & -- & - & - & -- & -- & -- & - \\
\hline Endosulfan I & -- & -- & -- & -- & -- & -- & - & -- & -- & -- & -- \\
\hline Endosulfan II & -- & -- & -- & -- & -- & -- & -- & -- & $\cdots$ & -- & -- \\
\hline Endosulfan sulfate & -- & -- & -- & -- & - & - & -- & $\cdots$ & -. & -- & -- \\
\hline Endrin & -- & -- & -- & -- & -- & -- & -- & - & -- &.- & -- \\
\hline Endrin aldehyde & -- & -- & -- & -- & -- & -- & -- & -- & -- & -- & -- \\
\hline Heptachlor & -- & -- & -- & -- & -- & -- & -- & -- & -- & -- & -- \\
\hline Heptachlor epoxide & - & -- & -- & -- & -- & -- & -- & -- & -- & -- & -- \\
\hline Lindane & -- & -- & -- & -- & -- & -- & -- & -- & -- & -- & -- \\
\hline Toxaphene & -- & - & -- & -- & -- & -- & -- & -- & -- & -- & -- \\
\hline
\end{tabular}

Note: Data qualifiers in table are those 1 
ANALYTICAL DATA SUMMARY

WELL CLUSTER MSB35

\begin{tabular}{|c|c|c|c|c|c|c|c|c|c|c|c|c|}
\hline Analyte & $\begin{array}{r}\text { Well ID: } \\
\text { Date: } \\
\end{array}$ & $\begin{array}{c}\text { MSB35A } \\
1 / 9 / 91\end{array}$ & $4 / 5 / 91$ & $8 / 5 / 91$ & $10 / 25 / 91$ & $1 / 14 / 92$ & $8 / 4 / 92$ & $10 / 17 / 92$ & $1 / 16 / 93$ & $4 / 10 / 93$ & 7/3/93 & $10 / 8 / 93$ \\
\hline \multicolumn{13}{|l|}{$\overline{\text { Metals }(\mu \mathrm{g} / \mathrm{L})}$} \\
\hline Aluminum, dissolved & & -- & -- & -- & -- & -- & -- & -- & -- & -- & -- & - \\
\hline Aluminum, total recoverable & & -- & -- & -- & -- & -- & -- & -- & -- & -- & -- & -. \\
\hline Antimony, total recoverable & & -- & -- & -- & -- & -- & -- & -- & -- & -. & -- & -- \\
\hline Arsenic, dissolved & & -- & -- & -- & -- & -- & -- & -- & -- & -- & -- & -- \\
\hline Arsenic, total recoverable & & -- & -- & -- &.- & -- & -- & $\ldots$ & -- & -- & -- & -- \\
\hline Barium, dissolved & & 4.6 & 7.7 & 5.69 & 5.75 & 6.19 & -- & -- & -- & -- & -- & -- \\
\hline Barium, total recoverable & & -- & -- & - & -- & -- & -- & -- & 6 & -- & 5.56 & -- \\
\hline Cadmium, total recoverable & & -- & -- & -- & -- & -- & -- & -- & -- & -. & -- & -- \\
\hline Calcium, dissolved & & 1000 & 1100 & 949 & 996 & -- & -- & -- & -- & -- & -. & -- \\
\hline Calcium, total recoverable & & -- & -- & - & - & -- & -- & -- & 995 & -- & -- & -- \\
\hline Chromium, dissolved & & -- & -- & -- & -- & -- & -- & -- & -- & -- & -- & -- \\
\hline Chromium, total recoverable & & -- & -- & -- & -- & -- & -- & $\cdots$ & -- & -- & -- & -- \\
\hline Cobalt, total recoverable & & -- & -- & -- & -- & -- & -- & -- & -- & -- & -- & -- \\
\hline Copper, dissolved & & -- & -- & -- & -- & -- & -- & -- & -- & -- & -- & - \\
\hline Copper, total recoverable & & -- & -- & -- & -- & -- & -- & -- & -- & -- & -- & -- \\
\hline Iron, dissolved & & 26 & 7.9 & -- & -- & -- & 4.96 & -- & -- & -- & -- & -- \\
\hline Iron, total recoverable & & -- & -- & -- & -- & -- & -- & -- & 6.64 & - & 8.11 & - \\
\hline Lead, dissolved & & -- & -- & -- & -- & -- & -- & -- & -- & -- & -- & -- \\
\hline Lead, total recoverable & & -- & -- & -- & -- & -- & -- & -- & -- & -- & -- & -- \\
\hline Lithium, total recoverable & & -- & -- & -- & -- & -- & -- & -- & -- & -- & -. & -- \\
\hline Magnesium, dissolved & & 480 & 460 & 473 & 520 & -- & -- & -- & -- & - & -- & -- \\
\hline Magnesium, total recoverable & & -- & -- & - & -- & -- & -- & -- & 509 & -- & -- & -- \\
\hline Manganese, dissolved & & 2.4 & 2.6 & 2.05 & 2.06 & 2.83 & 2.57 & -- & -- & -- & -- & -- \\
\hline Manganese, total recoverable & & -- & -- & -- & -- & -- & -- & -- & 2.08 & -- & 2.1 & -- \\
\hline Mercury, dissolved & & 3.9 & -- & -- & -- & -- & -- & -- & -- & -- & -- & -- \\
\hline Mercury, total & & -- & -- & -- & -- & -- & -- & -- & -- & -- & -- & -- \\
\hline Nickel, dissolved & & -- & - & -- & -- & -- & -- & -- & -- & -- & -- & -- \\
\hline Nickel, total recoverable & & -- & -- & -- & -- & -- & -- & -- & -- & -- & -- & -- \\
\hline Potassium, dissolved & & -- & -- & -- & -- & -- & -- & - & -- & -- & -- & -- \\
\hline Potassium, total recoverable & & -- & -- & -- & -- & -- & -- & -- & -- & -- & -- & -- \\
\hline Selenium, dissolved & & -- & -- & -- & -- & - & -- & -- & -- & -- & -- & -- \\
\hline Selenium, total recoverable & & -- & -- & -- & -- & -- & -- & -- & $2 \mathrm{UJ}$ & - & -- & -- \\
\hline Silica, dissolved & & 15000 & 15000 & 15900 & 15800 & -- & -- & -- & -- & -- & -- & -- \\
\hline
\end{tabular}


ANALYTICAL DATA SUMMARY

WELL CLUSTER MSB35

\begin{tabular}{|c|c|c|c|c|c|c|c|c|c|c|c|}
\hline $\begin{array}{lr} & \text { Well ID: } \\
& \text { Date: } \\
\text { Analyte } & \\
\end{array}$ & $\begin{array}{c}\text { MSB35A } \\
\text { 1/9/91 }\end{array}$ & 4/5/91 & $8 / 5 / 91$ & $10 / 25 / 91$ & $1 / 14 / 92$ & $8 / 4 / 92$ & $10 / 17 / 92$ & $1 / 16 / 93$ & $4 / 10 / 93$ & $7 / 3 / 93$ & $10 / 8 / 93$ \\
\hline Silica, total recoverable & -- & -- & -- & -- & -- & -- & -- & 16900 & -- & -- & -- \\
\hline Silver, dissolved & -- & -- & -- & -- & -- & -- & $-\cdot$ & $-\cdot$ & -- & -- & -- \\
\hline Sodium, dissolved & 2000 & 2100 & 1960 & 2110 & -- & -- & -- & -- & -- & -- & $\sim$ \\
\hline Sodium, total recoverable & -- & -- & -- & -- & -- & -- & -- & 2190 & -- & -- & -- \\
\hline Uranium, dissolved & -- & -- & -- & -- & -- & -- & - & -- & -- & -- & -- \\
\hline Uranium, total recoverable & -- & -- & -- & -- & -- & -- & -- & -- & -- & -- & -- \\
\hline Zinc, dissolved & -- & -- & -- & -- & -- & -- & -- & -- & -- & -- & -- \\
\hline Zinc, total recoverable & -- & - & -- & -- & -- & -- & -- & - & - & -- & -- \\
\hline \multicolumn{12}{|l|}{ Inorganics } \\
\hline Chloride (mg/L) & 2.56 & 2.43 & 2.62 & 2.6 & -- & -- & -- & 2.98 & - & -- & -- \\
\hline Cyanide $(\mu \mathrm{g} / \mathrm{L})$ & -- & -- & -- & -- & -- & -- & -- & -- & -- & -- & - \\
\hline Fluoride (mg/L) & -- & -- & -- & -- & -- & -- & -- & -- & -- & -- & -- \\
\hline Nitrate as nitrogen $(\mathrm{mg} / \mathrm{L})$ & -- & 1.12 & 0.84 & -- & 1 & -- & -- & -- & -- & -- & -- \\
\hline Nitrate-nitrite as nitrogen $(\mathrm{mg} / \mathrm{L})$ & 1.24 & -- & 0.84 & 1.18 & -- & 1.11 & -- & 1.12 & -- & 1.02 & -- \\
\hline Sulfate $(\mathrm{mg} / \mathrm{L})$ & 1.66 & 2.78 & - & -- & -- & -- & -- & -- & -- & -- & -- \\
\hline Total phosphates (as P) (mg/L) & -- & -- & -- & - & -- & -- & - & -- & -- & $-\cdot$ & -- \\
\hline \multicolumn{12}{|l|}{ General Chemistry } \\
\hline $\mathrm{pH}$ (std units) & 5.14 & 5.19 & 5.15 & $5.17 \mathrm{~J}$ & -- & -- & -- & $5.13 \mathrm{~J}$ & $5.23 \mathrm{~J}$ & $4.89 \mathrm{~J}$ & $5.15 \mathrm{~J}$ \\
\hline Specific conductance $(\mu \mathrm{S} / \mathrm{cm})$ & 22 & 18 & 20 & 25 & - & -- & -- & 28 & 29 & 25 & 27.4 \\
\hline Total dissolved solids (mg/L) & 26 & 24 & 45 & 35 & -- & -- & -- & 30 & 20 & 27 & 38 \\
\hline Oil \& grease & -- & -- & -- & - & - & -- & -- & -- & -- & -- & -- \\
\hline Phenols $(\mu \mathrm{g} / \mathrm{L})$ & -- & -- & -- & -- & -- & -- & -- & -- & -- & -- & -- \\
\hline Total organic carbon (mg/L) & -- & $\cdots$ & -- & -- & - & -- & -- & -- & -- & -- & $\cdots$ \\
\hline Total organic halogens $(\mu \mathrm{g} / \mathrm{L})$ & -- & 15 & 273 & $\cdots$ & -- & -- & -- & -- & -- & -- & -- \\
\hline \multicolumn{12}{|l|}{ Radioactivity } \\
\hline Gross alpha (pCi/L) & -- & -- & -- & - & -- & -- & -- & -- & -- & -- & -- \\
\hline Nonvolatile beta $(\mathrm{pCi} / \mathrm{L})$ & -- & -- & -- & -- & -- & $-\cdot$ & -- & -- & -- & -- & -- \\
\hline Total activity (PCML) & -- & -- & -- & -- & -- & -- & -- & - & $-\cdot$ & -- & -- \\
\hline Radium, total alpha-emitting (pCi/L) & -- & - & -- & 1.5 & -- & -- & -- & 1.3 & -- & -- & - \\
\hline Radium-226 (pCi/L) & -- & -- & -- & -- & - & -- & -- & -- & -- & -- & -- \\
\hline Radium 228 (pCi/L) & -- & -- & -- & -- & -- & -- & - & -- & -- & - & -- \\
\hline
\end{tabular}


ANALYTICAL DATA SUMMARY

WELL CLUSTER MSB35

\begin{tabular}{|c|c|c|c|c|c|c|c|c|c|c|c|}
\hline $\begin{array}{lr} & \text { Well ID: } \\
& \text { Date: } \\
\text { Analyte } & \\
\end{array}$ & $\begin{array}{c}\text { MSB35A } \\
1 / 9 / 91\end{array}$ & $4 / 5 / 91$ & 8/5/91 & $10 / 25 / 91$ & $1 / 14 / 92$ & $8 / 4 / 92$ & $10 / 17 / 92$ & 1/16/93 & 4/10/93 & 7/3/93 & $10 / 8 / 93$ \\
\hline Tritium (PCML) & -- & -- & - & -- & - & -- & -- & -- & -- & -- & -- \\
\hline Uranium alpha activity $(\mathrm{pCi} / \mathrm{L})$ & -- & -- & -- & -- & -- & -- & -- & -- & -- & -- & -- \\
\hline Uranium-233/234 (pCi/L) & -- & -- & -- & -- & -- & -- & -- & -- & - & - & - \\
\hline Uranium-234 (pCi/L) & -- & -- & -- & -- & -- & -- & -- & -- & -- & -- & -- \\
\hline Uranium-235 (pCi/L) & -- & -- & -- & -- & -- & -- & -- & - & - & -- & -- \\
\hline Uranium-238 (pCi/L) & -- & -- & -- & -- & -- & - & -- & -- & -- & -- & -- \\
\hline \multicolumn{12}{|l|}{ Volatile Organics (SW8240) ( $\mu \mathrm{g} / \mathrm{L})$} \\
\hline 1,1,1-Trichloroethane & -- & -- & -- & -- & -- & -- & -- & -- & -- & -- & -- \\
\hline 1,1,2,2-Tetrachloroethane & -- & -- & -- & -- & -- & -- & -- & -- & -- & -- & -- \\
\hline 1,1,2-Trichloroethane & - & -- & -- & -- & -- & -- & -- & -- & -- & -- & - \\
\hline 1,1-Dichloroethane & -- & -- & -- & - & -- & -- & -- & -- & -- & -- & -- \\
\hline 1,1-Dichloroethylene & -- & -- & -- & -- & -- & - & -- & -- & -- & -- & -- \\
\hline 1,2-Dichloroethane & -- & -- & -- & -- & -- & -- & -- & -- & -- & -- & -- \\
\hline 1,2-Dichloropropane & -- & -- & -- & -- & -- & -- & -- & -- & -- & -- & -- \\
\hline 2-Chloroethyl vinyl ether & -- & -- & -- & -- & -- & -- & -- & -- & - & -- & -- \\
\hline Benzene & -- & -- & -- & -- & - & -- & -- & -- & -- & -- & -- \\
\hline Bromodichloromethane & -- & -- & -- & -- & -- & -- & -- & -- & -- & -- & -- \\
\hline Bromoform & -- & -- & -- & - & -- & -- & -- & -- & -- & -- & -- \\
\hline Bromomethane (Methyl bromide) & -- & -- & -- & -- & -- & -- & -- & -- & -- & -- & - \\
\hline Carbon tetrachloride & -- & -- & -- & - & -- & -- & -- & -- & -- & -- & -- \\
\hline Chlorobenzene & -- & -- & -- & -- & -- & -- & -- & -- & -- & -- & -- \\
\hline Chloroethane & -- & -- & -- & -- & -- & -- & -- & -- & -- & -- & -- \\
\hline Chloroform & -- & -- & -- & -- & -- & -- & -- & -- & -- & -- & -- \\
\hline Chloromethane (Methyl chloride) & -- & - & -- & -- & -- & -- & -- & -- & -- & - & -- \\
\hline cis-1,3-Dichloropropene & -- & -- & -- & -- & -- & -- & -- & -- & -- & -- & - \\
\hline Dibromochloromethane & -- & -- & -- & -- & -- & -- & -- & - & -- & -- & -- \\
\hline Ethylbenzene & -- & -- & -- & -- & -- & - & -- & -- & -- & -- & -- \\
\hline Methylene chloride (Dichloromethane) & -- & -- & -- & -- & -- & -- & -- & -- & -- & - & -- \\
\hline Tetrachloroethylene & -- & - & -- & -- & -- & -- & -- & -- & -- & - & -- \\
\hline Toluene & -- & -- & -- & -- & -- & -- & -- & -- & -- & -- & -- \\
\hline trans-1,2-Dichloroethylene & -- & -- & -- & -- & - & -- & -- & -- & -- & -- & -- \\
\hline trans-1,3-Dichloropropene & -- & -- & - & -- & -- & -- & -- & -- & -- & -- & -- \\
\hline Trichloroethylene & 1.81 & 1.65 & 1.34 & 1.37 & -- & 1.9 & 2.39 & 1.85 & -- & -- & - \\
\hline
\end{tabular}


ANALYTICAL DATA SUMMARY

WELL CLUSTER MSB35

\begin{tabular}{|c|c|c|c|c|c|c|c|c|c|c|c|}
\hline $\begin{array}{lr} & \text { Well ID: } \\
& \text { Date: } \\
\text { Analyte } & \\
\end{array}$ & $\begin{array}{c}\text { MSB35A } \\
1 / 9 / 91\end{array}$ & $4 / 5 / 91$ & $8 / 5 / 91$ & $10 / 25 / 91$ & $1 / 14 / 92$ & $8 / 4 / 92$ & $10 / 17 / 92$ & $1 / 16 / 93$ & $4 / 10 / 93$ & $7 / 3 / 93$ & $10 / 8 / 93$ \\
\hline Trichlorofluoromethane & -- & -- & -- & -- & -- & -- & -- & -- & -- & - & -- \\
\hline Vinyl chloride (Chloroethene) & -- & -- & - & -- & -- & -- & -- & - & -- & -- & -- \\
\hline \multicolumn{12}{|l|}{ Herbicides (SW8150) $(\mu \mathrm{g} / \mathrm{L})$} \\
\hline 2,4,5-TP (Silvex) & -- & -- & -- & -- & -- & -- & - & -- & -- & -- & -- \\
\hline 2,4-Dichlorophenoxyacetic acid (2,4-D) & -- & -- & -- & -- & - & -- & -- & -- & -- & -- & -- \\
\hline \multicolumn{12}{|l|}{ Pesticides (SW8080) $(\mu \mathrm{g} / \mathrm{L})$} \\
\hline Lindane & -- & -- & -- & -- & -- & -- & -- & -- & - & -- & $\cdots$ \\
\hline
\end{tabular}

Note: Data qualifiers are those reported

by the laboratory. 
ANALYTICAL DATA SUMMARY

WELL CLUSTER MSB35

\begin{tabular}{|c|c|c|c|c|c|c|c|c|c|c|c|c|}
\hline Analyte & $\begin{array}{r}\text { Well ID: } \\
\text { Date: }\end{array}$ & $\begin{array}{c}\text { MSB35A, } \\
1 / 14 / 94\end{array}$ & $\begin{array}{l}\text { 8/10/94 } \\
\text { 8/10 }\end{array}$ & 1/11/95 & $\begin{array}{c}\text { MSB35B } \\
1 / 9 / 91\end{array}$ & 4/5/91 & $8 / 5 / 91$ & $10 / 25 / 91$ & $1 / 14 / 92$ & $8 / 4 / 92$ & $1 / 16 / 93$ & $4 / 10 / 93$ \\
\hline Metals $(\mu \mathrm{g} / \mathrm{L})$ & & & & & & & & & & & & \\
\hline Aluminum, dissolved & & -- & -- & -- & -- & -- & -- & -- & -- & - & -- & -- \\
\hline Aluminum, total recoverable & & -- & -- & -- & -- & -- & -- & -- & -- & -- & -- & -- \\
\hline Antimony, total recoverable & & -- & -- & -- & -- & -- & -- & -- & - & -- & -- & -- \\
\hline Arsenic, dissolved & & -- & -- & -- & -- & 2.83 & -- & -- & -- & -- & -- & - \\
\hline Arsenic, total recoverable & & -- & -- & -- & -- & - & -- & -- & -- & -- & -- & -- \\
\hline Barium, dissolved & & -- & -- & -- & 3.1 & $5.5 / 5.6$ & 5.15 & 5.05 & 5.28 & -- & -- & - \\
\hline Barium, total recoverable & & 5.75 & 5.45 & 5.23 & -- & -- & -- & -- & -- & -- & 4.65 & - \\
\hline Cadmium, total recoverable & & -- & -- & -- & -- & -- & -- & -- & - & - & - & -- \\
\hline Calcium, dissolved & & -- & -- & -- & 1900 & $1800 / 1800$ & 2630 & 2520 & -- & -- & -- & $\because$ \\
\hline Calcium, total recoverable & & -- & -- & -- & -- & -- & -- & -- & -- & -- & 2030 & -- \\
\hline Chromium, dissolved & & -- & -- & -- & -- & -- & -- & -- & -- & -- & -- & -- \\
\hline Chromium, total recoverable & & -- & -- & -- & -- & -- & -- & -- & -- & -- & -- & -- \\
\hline Cobalt, total recoverable & & -- & -- & -- & -- & -- & -- & -- & -- & -- & -- & - \\
\hline Copper, dissolved & & -- & -- & -- & -- & -- & -- & -- & -- & -- & -- & -- \\
\hline Copper, total recoverable & & -- & -- & -- & -- & -- & -- & -- & -- & -- & -- & -- \\
\hline Iron, dissolved & & -- & -- & -- & 270 & $7.6 / 9.6$ & -- & -- & - & 10.9 & -- & -- \\
\hline Iron, total recoverable & & $4.95 \mathrm{~J}$ & 7.03 & 18 & -- & -- & -- & -- & -- & -- & 7.28 & $-\cdot$ \\
\hline Lead, dissolved & & -- & -- & -- & -- & -- & -- & -- & -- & -- & -- & -- \\
\hline Lead, total recoverable & & -- & -- & -- & -- & - & -- & - & -- & -- & -- & -- \\
\hline Lithium, total recoverable & & -- & -- & - & -- & -- & -- & -- & -- & -- & -- & -- \\
\hline Magnesium, dissolved & & -- & -- & -- & 130 & $120 / 130$ & 154 & 150 & -- & -- & -- & -- \\
\hline Magnesium, total recoverable & & -- & -- & -- & -- & -- & -- & -- & - & -- & 140 & -- \\
\hline Manganese, dissolved & & -- & -- & -- & -- & -- & -- & -- & -- & -- & -- & - \\
\hline Manganese, total recoverable & & -- & -- & -- & -- & -- & -- & -- & -- & -- & -- & $-\cdot$ \\
\hline Mercury, dissolved & & -- & -- & -- & -- & -- & -- & 0.931 & -- & -- & -- & -- \\
\hline Mercury, total & & -- & -- & -- & -- & -- & -- & -- & -- & - & -- & -- \\
\hline Nickel, dissolved & & -- & -- & -- & -- & -- & -- & -- & -- & -- & -- & -- \\
\hline Nickel, total recoverable & & -- & -- & -- & -- & - & -- & -- & -- & -- & -- & -- \\
\hline Potassium, dissolved & & -- & -- & -- & -- & -- & -- & -- & -- & -- & -- & -- \\
\hline Potassium, total recoverable & & -- & -- & - & -- & -- & $-\cdot$ & -- & -- & -- & -- & -- \\
\hline Selenium, dissolved & & -- & -- & -- & -- & -- & -- & -- & -- & -- & -- & -- \\
\hline Selenium, total recoverable & & -- & $-\cdot$ & -- & -- & -- & -- & -- & -- & -- & $2 \mathrm{UJ}$ & -- \\
\hline Silica, dissolved & & -- & -- & -- & 8000 & $8200 / 8700$ & 8390 & 8310 & -- & -- & - & -- \\
\hline
\end{tabular}


ANALYTICAL DATA SUMMARY

WELL CLUSTER MSB35

\begin{tabular}{|c|c|c|c|c|c|c|c|c|c|c|c|}
\hline $\begin{array}{r}\text { Well ID: } \\
\text { Date: } \\
\end{array}$ & $\begin{array}{c}\text { MSB35A, } \\
1 / 14 / 94\end{array}$ & $\begin{array}{l}\text { cont. } \\
8 / 10 / 94\end{array}$ & 1/11/95 & $\begin{array}{c}\text { MSB35B } \\
1 / 9 / 91\end{array}$ & $4 / 5 / 91$ & $8 / 5 / 91$ & $10 / 25 / 91$ & $1 / 14 / 92$ & $8 / 4 / 92$ & $1 / 16 / 93$ & 4/10/93 \\
\hline Silica, total recoverable & -- & -- & -- & -- & -- & -- & -- & -- & -- & 8780 & -- \\
\hline Silver, dissolved & -- & -- & -- & -- & -- & -- & -- & -- & -- & -- & -- \\
\hline Sodium, dissolved & -- & -- & -- & 4000 & $4100 / 4200$ & 3570 & 3660 & -- & -- & -- & -- \\
\hline Sodium, total recoverable & -- & -- & -- & -- & -- & -- & -- & -- & -- & 3660 & -- \\
\hline Uranium, dissolved & -- & -- & -- & -- & -- & -- & -- & -- & -- & -- & -- \\
\hline Uranium, total recoverable & -- & -- & -- & -- & -- & -- & -- & -- & -- & -- & -- \\
\hline Zinc, dissolved & -- & -- & -- & -- & -- & -- & -- & -- & -- & -- & -- \\
\hline Zinc, total recoverable & -- & 22.6 & $2.66 \mathrm{~J}$ & -- & -- & -- & -- & -- & -- & -- & -- \\
\hline \multicolumn{12}{|l|}{ Inorganics } \\
\hline Chloride (mg/L) & -- & -- & -- & 3.15 & $3.13 / 3.15$ & 3.14 & 3.28 & -- & -- & 3.35 & -- \\
\hline Cyanide $(\mu \mathrm{g} / \mathrm{L})$ & - & -- & $8.33 \mathrm{UJ}$ & -- & -- & -- & -- & -- & - & -- & -- \\
\hline Fluoride (mg/L) & -- & -- & -- & -- & -- & -- & -- & -- & -- & -- & $\cdots$ \\
\hline Nitrate as nitrogen $(\mathrm{mg} / \mathrm{L})$ & -- & -- & -- & -- & $0.18 / 0.19$ & 0.2 & -- & 0.16 & -- & -- & -- \\
\hline Nitrate-nitrite as nitrogen $(\mathrm{mg} / \mathrm{L})$ & 0.98 & 0.874 & 0.825 & 0.2 & -- & 0.2 & 0.24 & -- & 0.18 & 0.22 & -- \\
\hline Sulfate $(\mathrm{mg} / \mathrm{L})$ & -- & $1.42 \mathrm{~J}$ & -- & 1.31 & $1.79 / 2.13$ & 1.21 & 1.17 & - & -- & 1.12 & $-\cdot$ \\
\hline Total phosphates (as P) (mg/L) & -- & -- & -- & -- & -- & -- & -- & -- & -- & -- & -- \\
\hline \multicolumn{12}{|l|}{ General Chemistry } \\
\hline pH (std units) & -- & -- & -- & 5.81 & $5.69 / 5.74$ & 5.86 & $5.82 \mathrm{~J}$ & -- & -- & $5.75 \mathrm{~J}$ & $5.83 \mathrm{~J}$ \\
\hline Specific conductance $(\mu \mathrm{S} / \mathrm{cm})$ & -- & -- & -- & 28 & $20 / 20$ & 30 & 30 & -- & -- & 30 & 30 \\
\hline Total dissolved solids (mg/L) & -- & -- & -- & 36 & $16-\mathrm{Nov}$ & 42 & 32 & -- & -- & 27 & 20 \\
\hline Oil \& grease & -- & -- & -- & -- & -- & -- & -- & -- & -- & -- & -- \\
\hline Phenols $(\mu \mathrm{g} / \mathrm{L})$ & -- & -- & -- & -- & -- & -- & -- & -- & -- & -- & -- \\
\hline Total organic carbon $(\mathrm{mg} / \mathrm{L})$ & -- & -- & -- & -- & -- & 1 & -- & -- & -- & -- & -- \\
\hline Total organic halogens $(\mu \mathrm{g} / \mathrm{L})$ & $5.6 \mathrm{~J}$ & $5.3 \mathrm{~J}$ & $8.14 \mathrm{~J}$ & -- & 26 & 92.4 & -- & 61.6 & -- & 10.6 & -- \\
\hline \multicolumn{12}{|l|}{ Radioactivity } \\
\hline Gross alpha (pCi/L) & $0.458 \mathrm{~J}$ & $0.594 \mathrm{UI}$ & $0.904 \mathrm{UI}$ & -- & - & -- & -- & -- & -- & -- & -- \\
\hline Nonvolatile beta $(\mathrm{pCi} / \mathrm{L})$ & $1.63 \mathrm{~J}$ & $0.405 \mathrm{UI}$ & $1.06 \mathrm{UI}$ & 2.7 & -- & -- & -- & -- & -- & -- & -- \\
\hline Total activity (PCML) & -- & -- & -- & -0.53 & -- & -- & -- & -- & -- & -- & -- \\
\hline Radium, total alpha-emitting $(\mathrm{pCi} / \mathrm{L})$ & $1.2 \mathrm{~J}$ & $0.6 \mathrm{~J}$ & $0.3 \mathrm{UI}$ & -- & -- & -- & 2 & -- & -- & -- & -- \\
\hline Radium-226 (pCi/L) & -- & -- & -- & -- & -- & -- & -- & -- & -- & -- & -- \\
\hline Radium $228(\mathrm{pCi} / \mathrm{L})$ & -- & -- & -- & -- & -- & -- & -- & -- & -- & -- & -- \\
\hline
\end{tabular}


ANALYTICAL DATA SUMMARY

WELL CLUSTER MSB35

\begin{tabular}{|c|c|c|c|c|c|c|c|c|c|c|c|}
\hline $\begin{array}{lr} & \text { Well ID: } \\
& \text { Date: } \\
\text { Analyte } & \\
\end{array}$ & $\begin{array}{c}\text { MSB35A, } \\
1 / 14 / 94\end{array}$ & $\begin{array}{l}\text { ont. } \\
8 / 10 / 94\end{array}$ & 1/11/95 & $\begin{array}{c}\text { MSB35B } \\
1 / 9 / 91\end{array}$ & $4 / 5 / 91$ & $8 / 5 / 91$ & $10 / 25 / 91$ & $1 / 14 / 92$ & $8 / 4 / 92$ & $1 / 16 / 93$ & $4 / 10 / 93$ \\
\hline Tritium (PCML) & $0.564 \mathrm{~J}$ & - & $0.403 \mathrm{UI}$ & -- & -- & -- & -- & -- & -- & - & - \\
\hline Uranium alpha activity $(\mathrm{pCi} / \mathrm{L})$ & -- & -- & -- & -- & -- & -- & -- & -- & -- & -- & -- \\
\hline Uranium-233/234 (pCi/L) & -- & -- & -- & -- & -- & -- & -- & -- & -- & -- & -- \\
\hline Uranium-234 (pCi/L) & -- & -- & -- & -- & -- & -- & -- & -- & -- & -- & -- \\
\hline Uranium-235 (pCi/L) & -- & -- & -- & -- & -- & -- & -- & -- & -- & -- & -- \\
\hline Uranium-238 (pCi/L) & -- & - & -- & -- & -- & -- & -- & -- & -- & -- & -- \\
\hline \multicolumn{12}{|l|}{ Volatile Organics (SW8240) $(\mu \mathrm{g} / \mathrm{L})$} \\
\hline 1,1,1-Trichloroethane & -- & -- & -- & -- & -- & -- & -- & -- & -- & -- & -- \\
\hline 1,1,2,2-Tetrachloroethane & -- & -- & -- & -- & -- & -- & -- & -- & -- & $\cdots$ & -- \\
\hline 1,1,2-Trichloroethane & -- & - & -- & -- & -- & -- & - & -- & -- & -- & -- \\
\hline 1,1-Dichloroethane & -- & -- & -- & -- & -- & -- & -- & -- & -- & -- & - \\
\hline 1,1-Dichloroethylene & -- & -- & -- & -- & -- & -- & -- & -- & -- & -- & -- \\
\hline 1,2-Dichloroethane & -- & - & -- & $\cdots$ & -- & -- & -- & -- & -- & -- & -- \\
\hline 1,2-Dichloropropane & -- & -- & -- & -- & -- & -- & -- & -- & -- & -- & -- \\
\hline 2-Chloroethyl vinyl ether & -- & -- & -- & -- & -- & -- & -- & - & -- & -- & -- \\
\hline Benzene & -- & -- & $\cdots$ & -- & -- & -- & -- & -- & -- & -- & $\cdots$ \\
\hline Bromodichloromethane & -- & -- & -- & -- & -- & -- & -- & -- & - & -- & -- \\
\hline Bromoform & -- & -- & -- & - & -- & -- & -- & -- & -- & -- & - \\
\hline Bromomethane (Methyl bromide) & -- & -- & -- & -- & -- & -- & -- & -- & -- & -- & -- \\
\hline Carbon tetrachloride & -- & - & -- & -- & -- & - & -- & - & -- & -- & -- \\
\hline Chlorobenzene & -- & -- & -- & -- & -- & -- & -- & -- & - & -- & -- \\
\hline Chloroethane & -- & -- & -- & - & -- & -- & -- & - & - & -- & -- \\
\hline Chloroform & -- & -- & -- & -- & -- & -- & -- & -- & -- & -- & -- \\
\hline Chloromethane (Methyl chloride) & 2.2 & -- & -- & -- & -- & - & -- & -- & -- & -- & -- \\
\hline cis-1,3-Dichloropropene & -- & - & -- & -- & -- & -- & -- & -- & -- & $\cdots$ & -- \\
\hline Dibromochloromethane & -- & -- & -- & -- & -- & -- & -- & -- & -- & -- & -- \\
\hline Ethylbenzene & - & -- & -- & -- & -- & -- & -- & -- & -- & -- & -- \\
\hline Methylene chloride (Dichloromethane) & -- & -- & -- & -- & -- & -- & -- & -- & - & -- & -- \\
\hline Tetrachloroethylene & -- & -- & -- & -- & -- & -- & - & - & -- & -- & -- \\
\hline Toluene & -- & -- & -- & -- & -- & -- & -- & -- & -- & -- & - \\
\hline trans-1,2-Dichloroethylene & -- & - & -- & -- & -- & -- & -- & -- & -- & -- & -- \\
\hline trans-1,3-Dichloropropene & -- & -- & -- & -- & -- & -- & -- & -- & - & -- & -- \\
\hline Trichloroethylene & -- & -- & -- & -- & -- & -- & -- & -- & -- & -- & -- \\
\hline
\end{tabular}


ANALYTICAL DATA SUMMARY

WELL CLUSTER MSB35

\begin{tabular}{|c|c|c|c|c|c|c|c|c|c|c|c|}
\hline $\begin{array}{lr} & \text { Well ID: } \\
& \text { Date: } \\
\text { Analyte } & \\
\end{array}$ & $\begin{array}{c}\text { MSB35A } \\
1 / 14 / 94\end{array}$ & $\begin{array}{l}\text { cont. } \\
8 / 10 / 94\end{array}$ & 1/11/95 & $\begin{array}{c}\text { MSB35B } \\
1 / 9 / 91\end{array}$ & $4 / 5 / 91$ & $8 / 5 / 91$ & $10 / 25 / 91$ & $1 / 14 / 92$ & $8 / 4 / 92$ & $1 / 16 / 93$ & $4 / 10 / 93$ \\
\hline Trichlorofluoromethane & -- & -- & -- & -- & -- & - & -- & -- & - & -- & -- \\
\hline Vinyl chloride (Chloroethene) & -- & - & -- & -- & -- & -- & -- & -- & - & -- & -- \\
\hline \multicolumn{12}{|l|}{ Herbicides (SW8150) $(\mu \mathrm{g} / \mathrm{L})$} \\
\hline 2,4,5-TP (Silvex) & -- & -- & -- & -- & -- & -- & -- & -- & -- & -- & -- \\
\hline 2,4-Dichlorophenoxyacetic acid (2,4-D) & -- & -- & -- & - & - & -- & -- & -- & -- & -- & -- \\
\hline \multicolumn{12}{|l|}{ Pesticides (SW8080) $(\mu \mathrm{g} / \mathrm{L})$} \\
\hline Lindane & -- & -- & - & -- & -- & -- & -- & -- & -- & -- & -- \\
\hline
\end{tabular}

Note: Data qualifiers are those reported

by the laboratory. 
ANALYTICAL DATA SUMMARY

WELL CLUSTER MSB35

\begin{tabular}{|c|c|c|c|c|c|c|c|c|c|c|c|c|}
\hline Analyte & $\begin{array}{r}\text { Well ID: } \\
\text { Date: }\end{array}$ & $\begin{array}{c}\text { MSB35B, } \\
7 / 3 / 93\end{array}$ & $\begin{array}{l}\text { cont. } \\
10 / 8 / 93\end{array}$ & $1 / 14 / 94$ & $8 / 10 / 94$ & 1/11/95 & \begin{tabular}{|c} 
MSB35TA \\
$1 / 9 / 91$
\end{tabular} & 4/5/91 & $8 / 5 / 91$ & $10 / 25 / 91$ & $1 / 14 / 92$ & $8 / 4 / 92$ \\
\hline Metals $(\mu \mathbf{g} / \mathbf{L})$ & & & & & & & & & & & & \\
\hline Aluminum, dissolved & & -- & -- & -- & -- & -- & -- & -- & -- & -- & - & -- \\
\hline Aluminum, total recoverable & & -- & -- & - & -- & -- & -- & -- & -- & -- & -- & $-\cdot$ \\
\hline Antimony, total recoverable & & -- & -- & -- & -- & -- & -- & -- & -- & -- & -- & -- \\
\hline Arsenic, dissolved & & -- & -- & - & -- & -- & -- & -- & -- & -- & -- & -- \\
\hline Arsenic, total recoverable & & -- & -- & -- & -- & -- & -- & -- & -- & -- & -. & -- \\
\hline Barium, dissolved & & -- & -- & -- & -- & -- & -- & 4.7 & - & -- & 3.04 & -- \\
\hline Barium, total recoverable & & 3.59 & -- & $4.42 \mathrm{~J}$ & $4.16 \mathrm{~J}$ & $3.76 \mathrm{~J}$ & -- & -- & -- & -. & -- & -. \\
\hline Cadmium, total recoverable & & -- & - & -- & -- & -- & -- & -- & -- & -- & -- & -- \\
\hline Calcium, dissolved & & -- & -- & -- & -- & -- & 490 & 670 & 521 & 519 & -- & -- \\
\hline Calcium, total recoverable & & -- & -- & -- & -- & -- & -- & - & -- & -- & -- & -- \\
\hline Chromium, dissolved & & -- & -- & -- & -- & -- & -- & -- & -- & -- & -- & $\ldots$ \\
\hline Chromium, total recoverable & & -- & -- & -- & -- & -- & - & -- & -- & -- & -- & -- \\
\hline Cobalt, total recoverable & & -- & -- & -- & -- & - & -- & -- & -- & -- & -- & -- \\
\hline Copper, dissolved & & -- & -- & -- & -- & -- & -- & -- & -- & -- & -- & -- \\
\hline Copper, total recoverable & & -- & -- & -- & -- & -- & -- & -- & -- & -- & -- & -- \\
\hline Iron, dissolved & & -- & -- & -- & - & -- & 100 & 99 & 102 & 91.8 & 88.7 & 88.2 \\
\hline Iron, total recoverable & & $4.1 \mathrm{~J} / 6.55$ & - & $6.61 \mathrm{~J}$ & $5.42 \mathrm{~J}$ & 8.99 & -- & -- & -- & -- & -- & -- \\
\hline Lead, dissolved & & -- & -- & -- & -- & -- & 6 & 5.7 & 6.63 & 6.4 & 5.42 & 4.96 \\
\hline Lead, total recoverable & & -- & -- & -- & -- & -- & -- & -- & -- & -- & -- & -- \\
\hline Lithium, total recoverable & & - & -- & -- & -- & - & -- & -- & -- & -- & -- & -- \\
\hline Magnesium, dissolved & & - & -- & -- & -- & - & 220 & 240 & 228 & 239 & -- & -- \\
\hline Magnesium, total recoverable & & -- & -- & -- & -- & -- & -- & -- & -- & -- & -- & -- \\
\hline Manganese, dissolved & & -- & -- & -- & -- & -- & 5.2 & 6.8 & 5.97 & 5.77 & 5.32 & 5.09 \\
\hline Manganese, total recoverable & & -- & -- & -- & -- & -- & -- & -- & -- & -- & -- & -- \\
\hline Mercury, dissolved & & -- & - & -- & -- & -- & -- & -- & -- & -- & -- & -- \\
\hline Mercury, total & & -- & -- & -- & -- & -- & -- & -- & - & -- & -- & -- \\
\hline Nickel, dissolved & & -- & -- & -- & -- & -- & -- & -- & -- & -- & -- & -- \\
\hline Nickel, total recoverable & & -- & -- & -- & -- & -- & -- & -- & -- & -- & $\cdots$ & -- \\
\hline Potassium, dissolved & & -- & -- & -- & -- & -- & -- & -- & -- & -- & -- & -- \\
\hline Potassium, total recoverable & & -- & -- & -- & -- & -- & -- & -- & - & -- & -- & -- \\
\hline Selenium, dissolved & & -- & -- & -- & -- & -- & -- & -- & -- & -- & -- & - \\
\hline Selenium, total recoverable & & -- & -- & -- & -- & -- & -- & -- & -- & -- & -- & -- \\
\hline Silica, dissolved & & -- & -- & - & -- & -- & 7800 & 7900 & 8510 & 8480 & -- & -- \\
\hline
\end{tabular}


ANALYTICAL DATA SUMMARY

WELL CLUSTER MSB35

\begin{tabular}{|c|c|c|c|c|c|c|c|c|c|c|c|}
\hline \multirow[b]{2}{*}{ Analyte } & \multicolumn{5}{|c|}{ MSB35B, cont. } & \multirow{2}{*}{\begin{tabular}{|c|} 
MSB35TA \\
$1 / 9 / 91$
\end{tabular}} & \multirow[b]{2}{*}{ 4/5/91 } & \multirow[b]{2}{*}{$8 / 5 / 91$} & \multirow[b]{2}{*}{$10 / 25 / 91$} & \multirow[b]{2}{*}{$1 / 14 / 92$} & \multirow[b]{2}{*}{$8 / 4 / 92$} \\
\hline & $7 / 3 / 93$ & $10 / 8 / 93$ & $1 / 14 / 94$ & $8 / 10 / 94$ & $1 / 11 / 95$ & & & & & & \\
\hline Silica, total recoverable & -- & - & -- & -- & -- & -- & -- & -- & -- & -- & -- \\
\hline Silver, dissolved & - & -- & -- & -- & -- & -- & -- & -- & -- & -- & -- \\
\hline Sodium, dissolved & -- & -- & -- & -- & -- & 1300 & 1700 & 1460 & 1380 & -- & -- \\
\hline Sodium, total recoverable & -- & -- & -- & -- & -- & -- & -- & -- & -- & -- & -- \\
\hline Uranium, dissolved & -- & -- & -- & -- & -- & -- & -- & - & -- & -- & -- \\
\hline Uranium, total recoverable & -- & -- & -- & -- & -- & -- & -- & -- & -- & -- & -- \\
\hline Zinc, dissolved & -- & -- & -- & -- & -- & -- & -- & -- & -- & -- & -- \\
\hline Zinc, total recoverable & -- & -- & -- & 45.5 & 25.8 & -- & -- & -- & -- & -- & -- \\
\hline \multicolumn{12}{|l|}{ Inorganics } \\
\hline Chloride (mg/L) & -- & -- & -- & -- & -- & 1.78 & 1.74 & 1.85 & 1.85 & -- & -- \\
\hline Cyanide $(\mu \mathrm{g} / \mathrm{L})$ & -- & -- & -- & -- & -- & -- & -- & -- & - & -- & -- \\
\hline Fluoride (mg/L) & -- & -- & -- & -- & -- & -- & -- & -- & -- & -- & -- \\
\hline Nitrate as nitrogen $(\mathrm{mg} / \mathrm{L})$. & 0.189 & -- & -- & -- & -- & -- & 0.32 & 0.27 & -- & 0.3 & -- \\
\hline Nitrate-nitrite as nitrogen $(\mathrm{mg} / \mathrm{L})$ & 0.19 & -- & 0.17 & 0.191 & 0.185 & 0.37 & -- & 0.27 & 0.36 & -- & 0.33 \\
\hline Sulfate $(\mathrm{mg} / \mathrm{L})$ & -- & $-\cdot$ & -- & 2.04 & $1.07 \mathrm{~J}$ & -- & 3.17 & -- & -- & -- & -- \\
\hline Total phosphates (as P) (mg/L) & - & -- & -- & -- & -- & -- & -- & -- & -- & -- & $-\cdot$ \\
\hline \multicolumn{12}{|l|}{ General Chemistry } \\
\hline pH (std units) & $5.4 \mathrm{~J} / 5.61 \mathrm{~J}$ & $5.89 \mathrm{~J}$ & -- & -- & -- & 5.24 & 5.26 & 5.25 & $5.27 \mathrm{~J}$ & -- & -- \\
\hline Specific conductance $(\mu \mathrm{S} / \mathrm{cm})$ & $28.9 \mathrm{~J} / 29$ & 34 & -- & -- & -- & 13 & 10 & 15 & 15 & -- & -- \\
\hline Total dissolved solids (mg/L) & $23 / 56$ & 32 & -- & -- & -- & 34 & 9 & 36 & 17 & -- & -- \\
\hline Oil \& grease & -- & -- & -- & - & -- & -- & -- & -- & -- & -- & -- \\
\hline Phenols $(\mu \mathrm{g} / \mathrm{L})$ & -- & -- & -- & -- & -- & -- & -- & -- & -- & $-\cdot$ & -- \\
\hline Total organic carbon $(\mathrm{mg} / \mathrm{L})$ & 1.92 & -- & -- & -- & $1.38 \mathrm{~J}$ & -- & -- & 12 & -- & - & -- \\
\hline lotal organic halogens $(\mu \mathrm{g} / \mathrm{L})$ & -- & -- & -- & -- & -- & 14 & -- & 62.7 & -- & 12.7 & -- \\
\hline \multicolumn{12}{|l|}{ Radioactivity } \\
\hline Gross alpha (pCi/L) & -- & -- & $0.275 \mathrm{UI}$ & $0.12 \mathrm{UI}$ & $0.356 \mathrm{UI}$ & - & -- & -- & -- & -- & -- \\
\hline Nonvolatile beta $(\mathrm{pCi} / \mathrm{L})$ & 1.3 & -- & $0.973 \mathrm{~J}$ & $-0.016 \mathrm{UI}$ & $0.663 \mathrm{UI}$ & 2.2 & -- & -- & -- & -- & -- \\
\hline Total activity (PCML) & -- & -- & -- & -- & -- & 0.36 & -- & -- & -- & -- & -- \\
\hline Radium, total alpha-emitting (pCi/L) & -- & -- & $0.8 \mathrm{~J}$ & $0.2 \mathrm{UI}$ & $0.2 \mathrm{UI}$ & -- & 1.7 & 1.2 & -- & -- & -- \\
\hline Radium-226 (pCi/L) & -- & -- & -- & -- & -- & -- & -- & -- & -- & -- & -- \\
\hline Radium $228(\mathrm{pCi} / \mathrm{L})$ & 1.2 & -- & -- & -- & -- & -- & -- & -- & -- & -- & -- \\
\hline
\end{tabular}


ANALYTICAL DATA SUMMARY

WELL CLUSTER MSB35

\begin{tabular}{|c|c|c|c|c|c|c|c|c|c|c|c|}
\hline $\begin{array}{r}\text { Well ID: } \\
\text { Date: }\end{array}$ & $\begin{array}{c}\text { MSB35B } \\
7 / 3 / 93\end{array}$ & $\begin{array}{l}\text { ont. } \\
10 / 8 / 93\end{array}$ & 1/14/94 & $8 / 10 / 94$ & $1 / 11 / 95$ & $\begin{array}{c}\text { MSB35TA } \\
1 / 9 / 91\end{array}$ & $4 / 5 / 91$ & $8 / 5 / 91$ & $10 / 25 / 91$ & $1 / 14 / 92$ & $8 / 4 / 92$ \\
\hline Tritium (PCML) & - & -- & $0.178 \mathrm{UI}$ & -- & $0.15 \mathrm{UI}$ & -- & -- & -- & -- & -- & -- \\
\hline Uranium alpha activity (pCi/L) & -- & -- & -- & -- & -- & -- & -- & - & -- & -- & -- \\
\hline Uranium-233/234 (pCi/L) & -- & -- & -- & -- & -- & -- & -- & -- & -- & -- & -- \\
\hline Uranium-234 (pCi/L) & -- & -- & -- & -- & -- & -- & -- & -- & -- & -- & -- \\
\hline Uranium-235 (pCi/L) & -- & - & -- & -- & - & -- & -- & -- & -- & -- & -- \\
\hline Uranium-238 (pCi/L) & -- & -- & -- & -- & -- & -- & -- & - & -- & -- & - \\
\hline \multicolumn{12}{|l|}{ Volatile Organics (SW8240) $(\mu \mathrm{g} / \mathrm{L})$} \\
\hline $1,1,1$-Trichloroethane & -- & -- & - & -- & -- & -- & -- & -- & - & -- & -- \\
\hline 1,1,2,2-Tetrachloroethane & -- & -- & -- & -- & -- & - & -- & -- & -- & -- & -- \\
\hline 1,1,2-Trichloroethane & -- & -- & -- & -- & -- & -- & -- & -- & -- & -- & -- \\
\hline 1,1-Dichloroethane & -- & -- & -- & -- & -- & -- & -- & -- & -- & -- & -- \\
\hline 1,1-Dichloroethylene & -- & -- & -- & -- & -- & -- & -- & -- & -- & -- & -- \\
\hline 1,2-Dichlorocthane & -- & -- & -- & -- & -- & -- & -- & -- & -- & -- & -- \\
\hline 1,2-Dichloropropane & -- & -- & -- & -- & -- & -- & -- & -- & -- & -- & -- \\
\hline 2-Chloroethyl vinyl ether & -- & -- & -- & -- & -- & -- & -- & -- & -- & -- & -- \\
\hline Benzene & -- & $\therefore$ & - & -- & -- & -- & -- & -- & -- & -- & -- \\
\hline Bromodichloromethane & -- & -- & - & -- & -- & -- & -- & -- & -- & -- & -- \\
\hline Bromoform & -- & -- & -- & -- & -- & -- & -- & -- & -- & -- & -- \\
\hline Bromomethane (Methyl bromide) & -- & -- & -- & -- & -- & -- & -- & -- & -- & -- & -- \\
\hline Carbon tetrachloride & -- & -- & -- & -- & -- & -- & -- & -- & -- & -- & -- \\
\hline Chlorobenzene & -- & -- & -- & -- & -- & -- & -- & -- & -- & -- & -- \\
\hline Chloroethane & -- & -- & -- & -- & -- & -- & -- & -- & -- & -- & -- \\
\hline Chloroform & -- & -- & -- & -- & -- & -- & -- & -- & -- & -- & -- \\
\hline Chloromethane (Methyl chloride) & -- & - & -- & -- & -- & -- & -- & -- & -- & -- & -- \\
\hline cis-1,3-Dichloropropene & -- & -- & - & -- & -- & -- & -- & -- & -- & -- & $\cdots$ \\
\hline Dibromochloromethane & -- & -- & -- & -- & -- & -- & -- & -- & -- & -- & -- \\
\hline Ethylbenzene & -- & -- & -- & -- & -- & -- & -- & -- & -- & -- & -- \\
\hline Methylene chloride (Dichloromethane) & 5 & - & $1 \mathrm{UJ}$ & -- & -- & -- & -- & -- & -- & -- & -- \\
\hline Tetrachloroethylene & -- & -- & -- & -- & -- & -- & -- & -- & -- & -- & -- \\
\hline Toluene & -- & -- & -- & -- & -- & -- & -- & -- & -- & -- & -- \\
\hline trans-1,2-Dichloroethylene & -- & -- & -- & -- & -- & -- & -- & -- & -- & - & -- \\
\hline trans-1,3-Dichloropropene & -- & -- & -- & -- & -- & -- & -- & -- & - & $\sim$ & -- \\
\hline Trichloroethylene & -- & -- & -- & -- & -- & -- & -- & -- & -- & -- & -- \\
\hline
\end{tabular}


ANALYTICAL DATA SUMMARY

WELL CLUSTER MSB35

\begin{tabular}{|c|c|c|c|c|c|c|c|c|c|c|c|}
\hline $\begin{array}{lr} & \text { Well ID: } \\
& \text { Date: } \\
\text { Analyte } & \\
\end{array}$ & $\begin{array}{c}\text { MSB35B } \\
7 / 3 / 93\end{array}$ & $\begin{array}{l}\text { ont. } \\
10 / 8 / 93\end{array}$ & $1 / 14 / 94$ & $8 / 10 / 94$ & 1/11/95 & $\begin{array}{c}\text { MSB35TA } \\
1 / 9 / 91\end{array}$ & $4 / 5 / 91$ & $8 / 5 / 91$ & $10 / 25 / 91$ & $1 / 14 / 92$ & $8 / 4 / 92$ \\
\hline Trichlorofluoromethane & - & -. & -- & -- & -- & -- & -- & -- & -- & -- & -- \\
\hline Vinyl chloride (Chloroethene) & - & -- & -- & -- & -- & -- & -- & - & -- & -- & -- \\
\hline \multicolumn{12}{|l|}{ Herbicides (SW8150) $(\mu \mathrm{g} / \mathrm{L})$} \\
\hline 2,4,5-TP (Silvex) & -- & -- & -- & -- & -- & -- & -- & -- & -- & -- & $\cdots$ \\
\hline 2,4-Dichlorophenoxyacetic acid (2,4-D) & -- & -- & -- & $\cdots$ & -- & -- & -- & -- & -- & -- & -- \\
\hline Pesticides (SW8080) $(\mu \mathrm{g} / \mathrm{L})$ & & & & & & & & & & & \\
\hline Lindane & -- & -- & -- & -- & -- & -- & -- & -- & -- & -- & -- \\
\hline
\end{tabular}

Note: Data qualifiers are those reported

by the laboratory. 
ANALYTICAL DATA SUMMARY

WELL CLUSTER MSB35

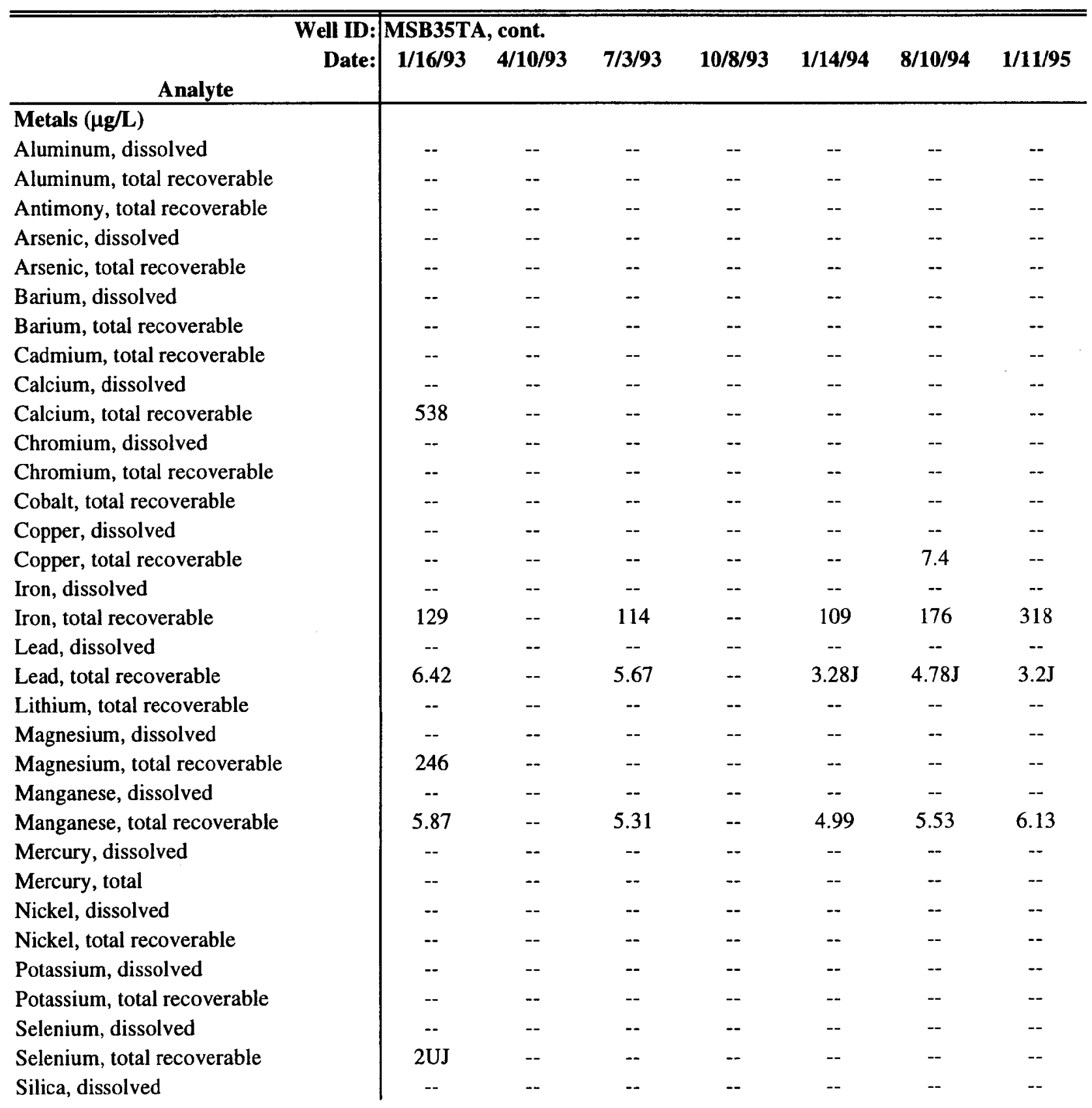


ANALYTICAL DATA SUMMARY

WELL CLUSTER MSB35

\begin{tabular}{|c|c|c|c|c|c|c|c|}
\hline $\begin{array}{lr} & \begin{array}{r}\text { Well ID: } \\
\text { Date: }\end{array} \\
\text { Analyte } & \\
\end{array}$ & $\begin{array}{c}\text { MSB35TA } \\
1 / 16 / 93\end{array}$ & $\begin{array}{l}\text { cont. } \\
4 / 10 / 93\end{array}$ & 7/3/93 & $10 / 8 / 93$ & $1 / 14 / 94$ & $8 / 10 / 94$ & 1/11/95 \\
\hline Silica, total recoverable & 9060 & -- & -- & - & -- & $\overline{--}$ & -- \\
\hline Silver, dissolved & -- & -- & -- & -- & - & -- & -- \\
\hline Sodium, dissolved & -- & -- & -- & -- & -- & -- & $\cdots$ \\
\hline Sodium, total recoverable & 1430 & -- & -- & - & - & -- & -- \\
\hline Uranium, dissolved & -- & -- & -- & -- & -- & -- & -- \\
\hline Uranium, total recoverable & - & -- & -- & -- & - & -- & -- \\
\hline Zinc, dissolved & -- & -- & -- & -- & -- & -- & -- \\
\hline Zinc, total recoverable & -- & -- & -- & -- & -- & 15.6 & -- \\
\hline \multicolumn{8}{|l|}{ Inorganics } \\
\hline Chloride (mg/L) & 1.89 & -- & -- & -- & -- & -- & -- \\
\hline Cyanide $(\mu \mathrm{g} / \mathrm{L})$ & -- & -- & -- & -- & -- & -- & -- \\
\hline Fluoride (mg/L) & -- & -- & -- & -- & -- & -- & -- \\
\hline Nitrate as nitrogen $(\mathrm{mg} / \mathrm{L})$ & -- & -- & -- & -- & -- & -- & -- \\
\hline Nitrate-nitrite as nitrogen $(\mathrm{mg} / \mathrm{L})$ & 0.36 & -- & 0.4 & -- & 0.3 & 0.316 & 0.319 \\
\hline Sulfate $(\mathrm{mg} / \mathrm{L})$ & $-\cdot$ & -- & -- & -- & -- & 1.67 & -- \\
\hline Total phosphates (as P) (mg/L) & -- & -- & -- & $\cdots$ & -- & -- & -- \\
\hline \multicolumn{8}{|l|}{ General Chemistry } \\
\hline $\mathrm{pH}$ (std units) & $5.35 \mathrm{~J}$ & $5.33 \mathrm{~J}$ & $4.99 \mathrm{~J}$ & $5.82 \mathrm{~J}$ & -- & -- & -- \\
\hline Specific conductance $(\mu \mathrm{S} / \mathrm{cm})$ & 19 & 20 & 17 & 15.7 & -- & -- & -- \\
\hline Total dissolved solids (mg/L) & 17 & 13 & 19 & 25 & -- & -- & -- \\
\hline Oil \& grease & -- & -- & -- & -- & - & -- & -- \\
\hline Phenols $(\mu \mathrm{g} / \mathrm{L})$ & -- & -- & -- & -- & -- & -- & -- \\
\hline Total organic carbon $(\mathrm{mg} / \mathrm{L})$ & -- & -- & -- & -- & $\cdots$ & -- & -- \\
\hline Total organic halogens $(\mu \mathrm{g} / \mathrm{L})$ & - & -- & - & -- & -- & -- & -- \\
\hline \multicolumn{8}{|l|}{ Radioactivity } \\
\hline Gross alpha (pCi/L) & -- & - & -- & -- & $0.209 \mathrm{UI}$ & $0.966 \mathrm{~J}$ & $0.446 \mathrm{UI}$ \\
\hline Nonvolatile beta $(\mathrm{pCi} / \mathrm{L})$ & - & -- & - & -- & $0.845 \mathrm{UI}$ & $0.81 \mathrm{UI}$ & 0.873 \\
\hline Total activity (PCML) & -- & -- & -- & - & -- & -- & -- \\
\hline Radium, total alpha-emitting ( $\mathrm{pCi} / \mathrm{L}$ ) & -- & -- & -- & -- & $1.3 \mathrm{~J}$ & OUI & $0.4 \mathrm{UI}$ \\
\hline Radium-226 (pCi/L) & -- & -- & -- & -- & -- & -- & -- \\
\hline Radium $228(\mathrm{pCi} / \mathrm{L})$ & -- & -- & -- & -- & -- & -- & -- \\
\hline
\end{tabular}


ANALYTICAL DATA SUMMARY

WELL CLUSTER MSB35

\begin{tabular}{|c|c|c|c|c|c|c|c|}
\hline $\begin{array}{lr} & \text { Well ID: } \\
& \text { Date: } \\
\text { Analyte } & \\
\end{array}$ & $\begin{array}{c}\text { MSB35TA } \\
1 / 16 / 93\end{array}$ & $\begin{array}{l}\text { cont. } \\
4 / 10 / 93\end{array}$ & 7/3/93 & $10 / 8 / 93$ & $1 / 14 / 94$ & $8 / 10 / 94$ & $1 / 11 / 95$ \\
\hline Tritium (PCML) & -- & -- & -- & -- & 0UI & -- & $-0.373 \mathrm{UI}$ \\
\hline Uranium alpha activity $(\mathrm{pCi} / \mathrm{L})$ & -- & -- & - & -- & -- & -- & -- \\
\hline Uranium-233/234 (pCi/L) & -- & -- & -- & -- & -- & -- & -- \\
\hline Uranium-234 (pCi/L) & -- & -- & -- & -- & -- & -- & -- \\
\hline Uranium-235 (pCi/L) & -- & -- & -- & -- & -- & -. & -- \\
\hline Uranium-238 (pCi/L) & - & -- &.- & -- & -- & -- & -- \\
\hline \multicolumn{8}{|l|}{ Volatile Organics (SW8240) $(\mu \mathrm{g} / \mathrm{L})$} \\
\hline 1,1,1-Trichloroethane & -- & -- & -- & -- & -- & -- & -- \\
\hline 1,1,2,2-Tetrachloroethane & -- & - & -- & -- & -- & -- & -- \\
\hline 1,1,2-Trichloroethane & -- & -- & -- & -- & -- & -- & -- \\
\hline 1,1-Dichloroethane & -- & -- & -- & -- & -- & -- & -- \\
\hline 1,1-Dichloroethylene & -- & -- & -- & -- & - & -- & -- \\
\hline 1,2-Dichloroethane & -- & -- & -- & - & - & -. & -- \\
\hline 1,2-Dichloropropane & - & -- & -- & -- & -- & -- & -- \\
\hline 2-Chloroethyl vinyl ether & -- & -- & -- & -- & -- & -- & -- \\
\hline Benzene & -- & - & -- & -- & -- & -- & -- \\
\hline Bromodichloromethane & -- & -- & -- & -- & -- & -. & - \\
\hline Bromoform & -- & -- & -- & -- & -- & -- & -- \\
\hline Bromomethane (Methyl bromide) & -- & -- & -- & -- & -- & -- & -- \\
\hline Carbon tetrachloride & -- & -- & -- & - & -- & -. & -- \\
\hline Chlorobenzene & -- & -- & -- & -- & -- & -- & -- \\
\hline Chloroethane & -- & -- & -- & -- & - & -- & -- \\
\hline Chloroform & -- & -- & -- & -- & -- & -- & -- \\
\hline Chloromethane (Methyl chloride) & -- & -- & - & -- & -- & -- & -- \\
\hline cis-1,3-Dichloropropene & -- & -- & -- & -- & -- & -- & -- \\
\hline Dibromochloromethane & -- & -- & -- & -- & -- & -- & -- \\
\hline Ethylbenzene & -- & -- & -- & -- & -- & -- & -- \\
\hline Methylene chloride (Dichloromethane) & -- & -- & -- & -- & $1.3 \mathrm{~J}$ & -- & -- \\
\hline Tetrachloroethylene & -- & -- & -- & -- & -- & -- & -- \\
\hline Toluene & -- & -- & -- & -- & -- & -- & -- \\
\hline trans-1,2-Dichloroethylene & -- & -- & -- & -- & -- & -- & -- \\
\hline trans-1,3-Dichloropropene & -- & -- & -- & -- & -- & -- & $-\cdot$ \\
\hline Trichloroethylene & -- & -- & -- & -- & - & -- & -- \\
\hline
\end{tabular}


ANALYTICAL DATA SUMMARY

WELL CLUSTER MSB35

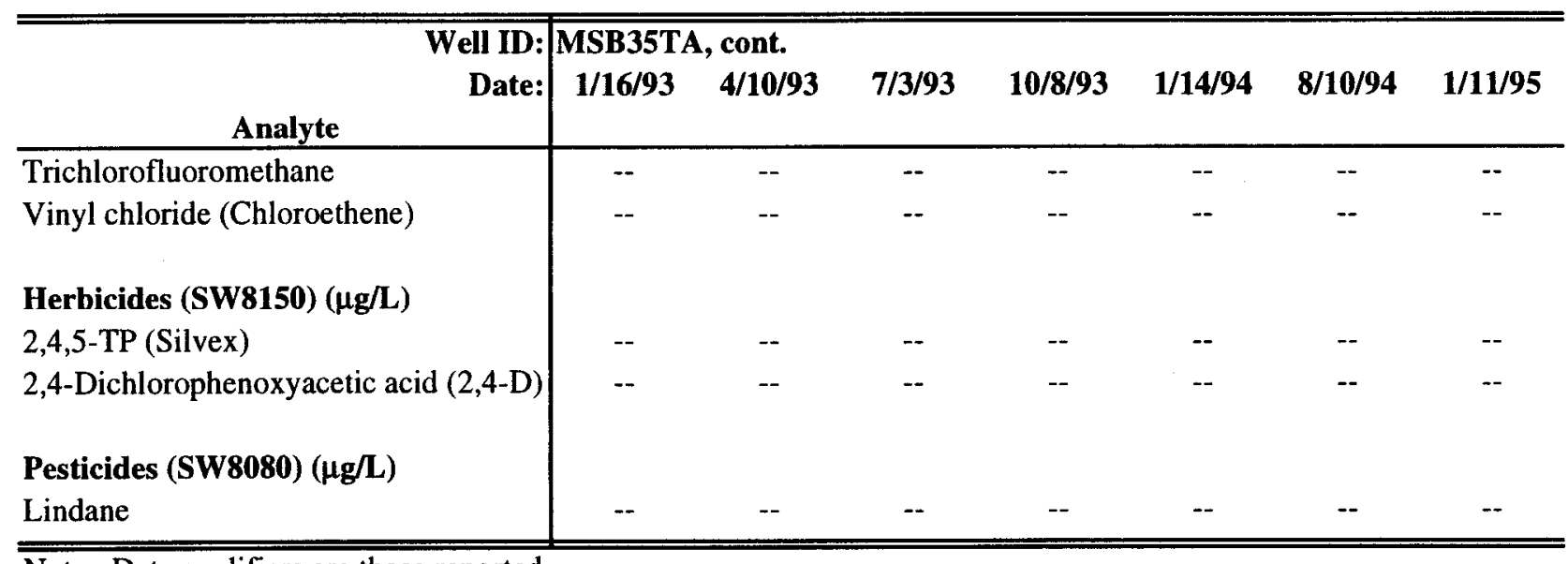

Note: Data qualifiers are those reported

by the laboratory. 